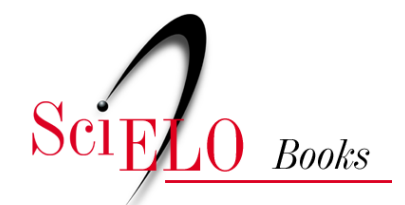

\title{
Medicinas indígenas e as políticas da tradição: entre discursos oficiais e vozes indígenas
}

\author{
Luciane Ouriques Ferreira
}

\section{SciELO Books / SciELO Livros / SciELO Libros}

FERREIRA, L.O. Medicinas indígenas e as políticas da tradição: entre discursos oficiais e vozes indígenas [online]. Rio de Janeiro: Editora FIOCRUZ, 2013. Saúde dos povos Indígenas collection. ISBN: 978-85-7541-510-8. Available from: doi: 10.7476/9788575415108. Also available in ePUB from: http://books.scielo.org/id/f48w3/epub/ferreira-9788575415108.epub.

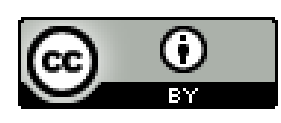

All the contents of this work, except where otherwise noted, is licensed under a Creative Commons Attribution $\underline{4.0 \text { International license. }}$

Todo o conteúdo deste trabalho, exceto quando houver ressalva, é publicado sob a licença Creative Commons Atribição 4.0. 


\section{FUNDAÇÃO OSWALDO CRUZ}

Presidente

Paulo Gadelha

Vice-Presidente de Ensino, Informação e Comunicação

Nísia Trindade Lima

\section{EDITORA FIOCRUZ}

Diretora

Nísia Trindade Lima

Editor Executivo

João Carlos Canossa Pereira Mendes

Editores Científicos

Gilberto Hochman

Ricardo Ventura Santos

Conselho Editorial

Ana Lúcia Teles Rabello

Armando de Oliveira Schubach

Carlos E. A. Coimbra Jr.

Gerson Oliveira Penna

Joseli Lannes Vieira

Ligia Vieira da Silva

Maria Cecília de Souza Minayo

Coleção Saúde dos Povos Indígenas

Editores Responsáveis: Ricardo Ventura Santos

Carlos E. A. Coimbra Jr. 
Medicinas Indígenas e as Políticas da Tradição: entre discursos oficiais e vozes indígenas 
Copyright (c) 2013 da autora

Todos os direitos desta edição reservados à

FUNDAÇÃO OSWALDO CRUZ / EDITORA

Revisão

Myllena Paiva

Irene Ernest Dias

Normatização de referências

Clarissa Bravo

Capa

Danowski Design

Criada a partir de peça Tipiti (Pap-ti), coletada em 1972 na Aldeia Kaxinawa, município de Feijó, AC. Fonte: Acervo Museu Rondon/Departamento de Antropologia — Instituto de Ciências Humanas e Sociais - UFMT.

Editoração eletrônica

Robson Lima

Catalogação na fonte

Instituto de Comunicação e Informação Científica e Tecnológica em Saúde/Fiocruz Biblioteca de Saúde Pública

F383 Ferreira, Luciane Ouriques

Medicinas Indígenas e as Políticas da Tradição: entre discursos oficiais e vozes indígenas. / Luciane Ouriques Ferreira. — Rio de Janeiro, Editora FIOCRUZ, 2013.

202 p., il., tab. (Coleção Saúde dos Povos Indígenas)

ISBN: 978-85-7541-424-8

1. População Indígena. 2. Saúde Materno-Infantil. 3. Cuidado Pré-Natal. 4. Medicina Tradicional. 5. Políticas Públicas de Saúde. 6. Plantas Medicinais. 7. Xamanismo. 8. Índios Sul-Americanos. I. Título.

CDD -615.321

2013

EDITORA FIOCRUZ

Av. Brasil, 4036 - 1o andar - sala 112 - Manguinhos

21040-361 - Rio de Janeiro - RJ

Tels.: (21) 3882-9039 e 3882-9007

Telefax: (21) 3882-9006

editora@fiocruz.br / www.fiocruz.br 
À minha amada família - Maria Neli Ouriques Ferreira, Jaci Vaz Ferreira (in memoriam) e Leandro Ouriques Ferreira -, por todo o amor compartilhado ao longo desta estrada 
A comunicação é um enigma porque o estar juntos, condição existencial para que se dê a possibilidade de qualquer estrutura dialógica do discurso, parece uma forma de transgredir ou superar a solidão de cada ser humano. Por solidão me refiro ao que é experimentado por uma pessoa e não pode ser transferido integralmente a alguém. Minha experiência não pode converter-se diretamente na tua experiência. Um acontecimento que pertence a um fluir do pensamento não pode ser transferido como tal a outro fluir do pensamento. Ainda assim, algo passa de mim para ti. Algo é transferido de uma esfera de vida a outra. Este algo não é a experiência tal como é experimentada, mas sim seu significado. Aqui está o milagre. A experiência tal como é experimentada, vivida, segue privada, porém sua significação, seu sentido, se faz público. A comunicação, dessa forma, é a superação da não comunicabilidade radical da experiência vivida tal como foi.

Paul Ricoeur, El lenguaje como discurso 


\section{Sumário}

Prefácio

1. Estado-Nação, Poder e Modernidade: revisitando conceitos

2. Os Discursos Oficiais e a Emergência do Tradicional como Objeto de Políticas Públicas.

3. Contexto de Emergência das Vozes Indígenas:

os encontros de parteiras, pajés e AISs no Alto Juruá

4. Cursos, Partos e Parteiras Tradicionais: apropriações indígenas dos conhecimentos e das coisas do branco

5. Os Outros Cuidadores: agência, intermedicalidade e gênero 109

6. Folhas, Rezas e Dietas: a emergência da medicina tradicional e do pré-natal indígena

7. Contrato, Dádiva e a Luta por Reconhecimento.

Conclusão

Referências. 


\section{Prefácio}

É com grande prazer que apresento este livro de Luciane Ouriques Ferreira, que foi minha aluna durante o seu doutorado na Universidade Federal de Santa Catarina (UFSC). Medicinas Indígenas e as Políticas da Tradição: entre discursos oficiais e vozes indígenas é uma importante contribuição aos campos da antropologia da saúde, das relações interétnicas na modernidade e das políticas de saúde indígena; por sua excelência e relevância para a antropologia contemporânea e para as políticas públicas, a tese de doutorado que lhe deu origem foi eleita pelo Programa de Pós-Graduação em Antropologia Social da UFSC a melhor de 2010.

O livro é muito mais que a apresentação dos resultados de uma pesquisa acadêmica realizada no âmbito de um programa de pós-graduação. É, sobretudo, o produto do compromisso da autora com a luta indígena e de sua capacidade de se distanciar suficientemente de seu papel como gerente da Área de Medicina Tradicional Indígena do Projeto Vigisus II/Funasa para fazer uma reflexão crítica sobre o programa que liderou durante quatro anos. Em todas as suas atividades, seja em pesquisa, seja em gerenciamento de programas de saúde indígena, o diálogo como compromisso e princípio norteador de suas relações com os povos indígenas é evidente. Esse compromisso se manifesta nesta obra como um eixo que atravessa a análise profunda e complexa dos resultados produzidos no âmbito de um dos projetos desenvolvidos pela Área de Medicina Tradicional Indígena (AMTI), sobre os sistemas de parto indígena dos povos do Alto Juruá, Acre. Fazer antropologia, para Luciane, é o compromisso com as relações dialógicas e com a pesquisa participativa (Ferreira, 2004a).

Conheci Luciane durante seu mestrado na Universidade Federal do Rio Grande do Sul sob a orientação do prof. Oscar Agüero, antropólogo argentino também comprometido com as relações democráticas e igualitárias entre as sociedades indígenas e o Estado. Em sua pesquisa de mestrado, "Mba'e Achÿ. a concepção cosmológica da doença entre os Mbyá-Guarani num contexto de relações interétnicas", defendida em 2001, ela não analisava o sistema de medicina tradicional como um vestígio do passado, estático. Ao contrário, explorava a relação de conceitos de saúde 
com as noções de pessoa e de cosmologia, demonstrando também a forma como o contato interétnico desencadeou doenças e transformações do sistema médico mbyá-guarani (Ferreira, 2001).

Tal experiência desdobrou-se em seu primeiro projeto de intervenção em saúde desenvolvido com o Centro de Monitoramento de Pesquisa e Intervenção em Alcoolismo e Saúde Mental nas Populações Indígenas e a Fundação Nacional de Saúde (Funasa), que contou com financiamento do Programa Vigisus/Funasa e acompanhamento do Ministério Público Federal - Procuradoria da República. Antes de entrar no doutorado, ela realizou um projeto para a redução do consumo de bebidas alcoólicas entre os Mbyá-Guarani do Rio Grande do Sul, o qual deu início ao desenvolvimento da metodologia comprometida e inovadora (Ferreira 2004a, 2004b) que subsequentemente fundamentou o planejamento das ações realizadas pelo Programa de Medicina Tradicional Indígena iniciado em 2004.

Em sua práxis comum, os profissionais da saúde alertados sobre o abuso de álcool entre os povos indígenas procuravam a solução desse complexo e heterogêneo problema mediante a simplificação, universalização e redução dos hábitos indígenas de beber ao alcoolismo, uma categoria biomédica e individualista. O projeto de intervenção de Luciane, ao contrário, baseou-se na construção de um diagnóstico antropológico participativo, que procurava descobrir as percepções e preocupações dos Mbyá-Guarani sobre o problema, negociar com as lideranças e desenvolver estratégias de fortalecimento dos modos tradicionais de fala dos xamãs (karaî) e conselheiros guarani (os Xondaro Marágatu) como forma de reduzir os danos causados pelo consumo do álcool nas comunidades indígenas.

A valorização e fortalecimento das medicinas tradicionais é objeto das demandas dos povos indígenas pelo reconhecimento de seus direitos culturais estabelecidos na Constituição Brasileira de 1988 e tema de discussões em conferências nacionais e nas políticas direcionadas à saúde indígena. Desde a $1^{\text {a }}$ Conferência Nacional de Proteção à Saúde Indígena, o Ministério da Saúde tem se esforçado para estruturar um subsistema de saúde indígena diferenciado, porém integrado ao Sistema Único de Saúde (SUS) e guiado pelos princípios de acesso universal, equidade, controle social, participação comunitária e, particularmente no caso dos povos indígenas, respeito e articulação com as especificidades étnicas e culturais dos grupos atendidos. No documento Política Nacional de Atenção à Saúde dos Povos Indígenas reconhece-se que todas as sociedades indígenas "dispõem de seus próprios sistemas de interpretação, prevenção e tratamento das doenças", ressaltando-se a importância de tais sistemas para a atenção à saúde das comunidades e recomendando-se a articulação dos serviços de saúde com esses saberes e práticas, de modo a "inseri-los, sempre que possível, nas rotinas do trabalho em saúde" (Brasil, 2002: 17, 18). Nesse documento também se afirma que a atenção básica oferecida pelas unidades de saúde dos Distritos Sanitários Especiais Indígenas (DSEIs) deve 
ser complementar, e não substituir as práticas de saúde tradicionais (Brasil, 2002: 15). Ou seja, há, na legislação brasileira e nos documentos da Funasa, desde a implantação do Subsistema de Saúde Indígena em 1999, uma preocupação explícita com a necessidade de articular o sistema sanitário oficial com as diversas práticas indígenas, visando a garantir atenção diferenciada à saúde dessas populações.

O compromisso de articular as práticas de saúde indígena com as dos serviços biomédicos foi reafirmado nas Diretrizes do Modelo de Gestão da Saúde Indígena, aprovadas pela Portaria n. 70/04. Em nível nacional, porém, o Departamento de Saúde Indígena da Funasa não estimulou nem orientou os profissionais da saúde que trabalham nos DSEIs a oferecer serviços segundo os princípios de atenção diferenciada. Geralmente, as tentativas de articulação com as práticas indígenas por parte das equipes multidisciplinares foram dispersas e localizadas. A prestação de serviços não se diferenciou das práticas biomédicas fora das áreas indígenas; houve pouca sensibilidade ou consciência das particularidades culturais por parte dos que trabalhavam como membros de uma equipe multidisciplinar. Aos profissionais, faltavam o compromisso e o interesse de desenvolver práticas de atenção diferenciada; além disso, mesmo que os tivessem, faltavam-lhes a preparação e a capacitação adequadas para implementarem um serviço orientado para o contexto sociocultural específico. Os gestores da política de saúde privilegiavam as ações em saúde de orientação estritamente biomédica, emitindo de Brasília diretrizes generalizantes que ignoravam, em geral, a diversidade cultural e as especificidades epidemiológicas das diferentes comunidades indígenas.

A partir de 2003, o discurso sobre a articulação dos serviços com a medicina tradicional como estratégia para efetivar a atenção diferenciada fortaleceu-se. Porém, para a maioria dos gestores e profissionais da saúde, a categoria 'medicina tradicional' era pensada como um conjunto de práticas indígenas supersticiosas e estáticas, e, assim, sujeitas à validação científica antes de serem instrumentalizadas pelas equipes médicas para melhorar as condições de saúde da população. Observou-se uma tendência a perceber essas práticas como universalmente manifestadas na pajelança, na atuação da parteira e/ou na manipulação de plantas medicinais. Tais representações essencialistas e universalistas da medicina tradicional ignoravam que, para os povos indígenas, tanto a medicina tradicional como a saúde integram, com suas especificidades, a sua pauta política e as suas estratégias de reivindicação por direitos perante o Estado. Além disso, como demonstrado por muitas pesquisas como as realizadas por Luciane Ouriques Ferreira, o domínio da saúde nas sociedades indígenas não corresponde ao domínio da biomedicina, que se limita aos processos biológicos do corpo.

Foi nesse contexto que Luciane se viu contratada para desenvolver o plano de ação da AMTI do Projeto Vigisus II para a implementação de estratégias de articulação entre os serviços de saúde e os sistemas sociomédicos indígenas, 
visando a "apoiar, viabilizar e criar condições para a atuação terapêutica das medicinas indígenas de forma articulada ao sistema oficial de saúde" (Ferreira, 2004c: 3). O programa da AMTI que vigorou entre 2004 e 2009, período em que Luciane gerenciou-o, destaca-se como exceção à norma das ações realizadas pela Funasa no âmbito do Subsistema de Atenção à Saúde Indígena. Como demonstrado por Carla Teixeira (2008) em análise sobre a história da formação da Funasa em 1991, suas origens se encontram na política sanitária do século XIX, fortemente marcada pelo autoritarismo nas intervenções e por uma tradição campanhista, caracterizada pela centralização no nível federal, pela focalização em doenças endêmicas e de natureza pontual e pelo autoritarismo. A AMTI rompia com a práxis de controle e contemplava a participação das comunidades em pleno reconhecimento de que o tema 'medicina tradicional' é, antes de tudo, um campo discursivo em construção contínua e uma demanda política dos povos indígenas dirigida à nação.

Durante seu período de vigência, a AMTI conduziu oito projetos de pesquisa-ação envolvendo líderes, organizações e comunidades indígenas, projetos selecionados pelo potencial das propostas apresentadas. Os temas dos projetos definidos pelas organizações indígenas envolvidas foram reunidos em três eixos temáticos: sistemas de atenção ao parto e atenção à saúde materno-infantil; plantas medicinais e remédios tradicionais; xamanismo e intermedicalidade. Além de partir dos interesses e necessidades expressas nas situações locais, os projetos contaram com a participação de antropólogos que etnografavam os processos de seus desenvolvimentos e orientavam os investigadores indígenas nas ações de pesquisa em campo. Como se pode perceber na iniciativa de valorização dos sistemas indígenas de parto do Alto Juruá aqui analisada, vários atores indígenas - líderes, xamãs, parteiras e agentes indígenas de saúde - participaram do projeto e da construção do diálogo com o órgão gestor da saúde indígena.

Os diálogos e reflexões promovidos por esses projetos contribuíram para caracterizar o programa desenvolvido pela AMTI como altamente inovador em comparação com as ações de saúde preconizadas pelos gestores da saúde indígena e executadas pelas equipes multidisciplinares que prestam serviços entre as populações indígenas. Justamente porque suas ações foram planejadas e executadas de forma participativa. Finalmente, o projeto promovia outra inovação: a avaliação e a reflexão sistematizada sobre os projetos de pesquisa-ação em encontros periódicos que congregavam os vários atores envolvidos na execução de suas atividades. Duas reuniões de monitoramento foram realizadas para esse fim, uma em 2006 e outra em 2007, incluindo representantes dos vários atores implicados nos projetos - líderes indígenas, antropólogos, assessores, profissionais e pesquisadores em saúde, representantes dos órgãos governamentais etc. Os relatórios dos projetos e os debates ressaltaram as complexidades, ambiguidades e implicações políticas da articulação com práticas de medicina tradicional no contexto da política de saúde 
indígena brasileira. Felizmente para o público maior, os resultados da primeira reunião foram publicados pela Funasa (Ferreira G Osório, 2007), porém os resultados do segundo encontro ainda precisam ser divulgados.

A publicação deste livro pela Editora Fiocruz como parte da Coleção Saúde dos Povos Indígenas marca a continuação dos seus esforços para divulgar as pesquisas interdisciplinares sobre o tema. A partir da década de 1990, a Editora Fiocruz assumiu a liderança em publicações no campo emergente de antropologia da saúde, inicialmente no âmbito de sua coleção Antropologia e Saúde, que hoje tem mais de vinte títulos publicados; em 2003 estabeleceu a coleção Saúde dos Povos Indígenas, da qual este livro faz parte. O estudo aqui apresentado contribui tanto para o avanço do campo da saúde indígena quanto para a análise das políticas nesse setor. Porém, além dos envolvidos com a questão indígena, interessa a todos os que se dedicam às políticas públicas de saúde em geral e à relação do Estado com as práticas de autoatenção de saúde das várias coletividades, sejam estas indígenas ou não.

\section{Esther Jean M. Langdon}

Professora do Departamento de Antropologia da Universidade Federal de Santa Catarina e coordenadora do Instituto Nacional de Pesquisa Brasil Plural

\section{Referências}

BRASIL. Ministério da Saúde. Funasa. Política Nacional de Atenção à Saúde dos Povos Indígenas. Brasília: Ministério da Saúde, 2002.

FERREIRA, L. O. O impacto do uso abusivo de bebidas alcoólicas sobre a pessoa Mbyá-Guarani, no Rio Grande do Sul. Tellus, 2(2): 39-64, 2001.

FERREIRA, L. O. O 'fazer antropológico' em ações voltadas para a redução do uso abusivo de bebidas alcoólicas entre os Mbyá-Guarani, no Rio Grande do Sul. In: LANGDON, E. G GARNELO, L. (Orgs.). Saúde dos Povos Indígenas: reflexões sobre antropologia participativa. Rio de Janeiro: Contracapa, ABA, 2004a.

FERREIRA, L. O. As 'boas palavras' dos Xondaro Marãgatu como alternativa para a redução do consumo de bebidas alcoólicas entre os Mbyá-Guarani, no Rio Grande do Sul (parte 2). Tellus, 4(7): 21-136, 2004b.

FERREIRA, L. O. Projeto Valorização e Adequação dos Sistemas de Parto Tradicionais das Etnias Indígenas do Acre e do Sul do Amazonas. Produto de consultoria Pnud, Projeto Vigisus II. Área de Medicina Tradicional Indígena. Brasília, 2004c.

FERREIRA, L. O. G OSÓRIO, P. Medicina tradicional indígena em contextos. In: REUNIÃO DE MONITORAMENTO, 1, 2007, Brasília. Anais... Brasília: Projeto Vigisus II, Funasa, 2007.

TEIXEIRA, C. C. Fundação Nacional de Saúde: a política brasileira de saúde indígena vista através de um museu. Etnográfica, 12(2): 323-351, 2008. 
Apresentação

Cada vez mais surgem no cenário nacional brasileiro iniciativas voltadas para o fortalecimento e a valorização de conhecimentos, práticas e praticantes tradicionais inscritos em contextos socioculturais particulares. Se, por um lado, o Estado, na última década, estimulado pelas tendências do desenvolvimento mundial, começa a elaborar normativas e políticas públicas que utilizam a noção de tradicional para qualificar seus objetos, por outro, iniciativas de "revitalização cultural" também passam a ser tomadas por povos e comunidades localmente situados, no intuito de contribuir para a sua reprodução social e econômica. Como exemplo dessas iniciativas, podem ser citadas duas experiências importantes de fortalecimento e "revitalização" das medicinas tradicionais indígenas: o Projeto Medicina Tradicional Baniwa, que integra o Projeto Rede Autônoma de Saúde Indígena da Universidade Federal do Amazonas (Garnelo, 2004a); e o Projeto Medicina Tradicional no Alto Rio Negro executado pela organização não governamental (ONG) Associação Saúde sem Limites em parceria com a Federação Indígena do Alto Rio Negro, entre 2001 e 2004 (Athias, 2007).

A medicina tradicional indígena constitui um dos objetos frequentemente pautados tanto pelas políticas públicas, aqui compreendidas como programas de ação governamental voltados para realizar objetivos e metas previamente estabelecidas (Dallari Bucci, 2006), quanto pela luta dos povos indígenas para fazer valer os seus direitos por uma atenção diferenciada à sua saúde. ${ }^{1}$ Apesar de atualmente não haver uma política nacional específica sobre esse tema, existe um conjunto de políticas públicas que usa a noção de tradição para qualificar os seus objetos e público-alvo. Essas políticas, aqui denominadas políticas da tradição, configuram uma particular formação discursiva, da qual fazem parte igualmente os discursos oficiais sobre as medicinas tradicionais indígenas.

Por que abordar as políticas da tradição se o foco deste livro recai sobre a emergência das medicinas tradicionais indígenas no campo das políticas públicas? Porque os enunciados que abordam o tema estão situados em um contexto discursivo mais amplo, configurado pelas relações estabelecidas entre o Estado brasileiro, os 
organismos internacionais e os povos indígenas. Em outras palavras, é importante analisar as políticas da tradição, na medida em que constituem o contexto oficial em que os discursos sobre as medicinas tradicionais indígenas circulam. Ao reconhecer a eficácia das medicinas tradicionais indígenas e estabelecer como uma das suas diretrizes a articulação dos serviços de saúde com os sistemas tradicionais indígenas de saúde, a Política Nacional de Atenção a Saúde Indígena (Brasil, 2002) instaurou as condições legais para que o governo, em parceria com a sociedade civil organizada, passasse a fomentar um conjunto de ações de desenvolvimento das medicinas indígenas. Ao mesmo tempo, abriu mais um canal de negociações interétnicas entre os povos indígenas e o Estado, por meio do qual recursos, bens e benefícios passaram a ser captados e revertidos por lideranças para atender aos interesses localmente situados de suas comunidades indígenas. Portanto, as relações interétnicas historicamente estabelecidas entre os povos indígenas e o Estado-nação são constitutivas do campo da saúde indígena no Brasil, configurando-o como um espaço fronteiriço de articulação das diferenças étnicas e culturais que nele interagem.

A heterogeneidade dos agentes que compõem esse campo, por sua vez, é marcada tanto pelos distintos pertencimentos étnicos (indígenas e não indígenas) quanto pelos variados vínculos que mantêm com as instituições nas quais atuam sejam governamentais ou não governamentais, sejam nacionais ou internacionais. E, na medida em que as perspectivas desses agentes são influenciadas pela posição que eles ocupam, o campo discursivo da saúde indígena passa a ser atravessado por diversas vozes e vários entendimentos, interesses e versões sobre as medicinas tradicionais indígenas. Os agentes socialmente posicionados, que falam sobre esse assunto, por sua vez, encontram-se em constantes disputas pelo poder simbólico para, ao fazerem prevalecer o seu ponto de vista, instituírem a sua verdade sobre as medicinas indígenas e a realidade sobre a qual atuam. Afinal, na luta política, são as disputas "pelo poder de conservar ou de transformar o mundo social, conservando ou transformando as categorias de percepção desse mundo" (Bourdieu, 2005: 142), que estão em jogo.

As posições que conformam o campo da saúde indígena estão distribuídas em um amplo espaço social, configurando uma rede de relações que vincula as múltiplas localidades - comunidades e povos indígenas - às esferas nacionais e internacionais. A dinâmica relacional mantida entre o global e os locais propicia que os discursos oficiais sobre as medicinas tradicionais indígenas irrompam nessas localidades, dinamizando interações sociais e transformando realidades sociomédicas. Assim, em razão das relações estabelecidas entre os diferentes agentes socialmente posicionados que atuam no campo, contextos translocais são fundados, dando lugar ao surgimento de novas formações culturais.

Este livro tem origem no trabalho do doutoramento, desenvolvido no âmbito do Programa de Pós-Graduação em Antropologia Social da Universidade Fede- 
ral de Santa Catarina, e seu objetivo é contribuir para a compreensão do processo de emergência da medicina tradicional indígena no campo das políticas de saúde indígena (Ferreira, 2010). Apresento, portanto, por um lado, um mapeamento dos discursos oficiais dos organismos internacionais e das políticas públicas brasileiras que empregam a noção de tradição para qualificar os seus objetos - medicina tradicional, parteiras tradicionais, conhecimentos tradicionais, povos e comunidades tradicionais. Por outro, considero as falas indígenas sobre os cuidados com a gestação e o parto proferidas durante eventos que, no decorrer de 2006, congregaram parteiras, pajés e agentes indígenas de saúde (AISs) de diferentes povos que habitam a região do Alto Juruá, estado do Acre. Esses encontros foram viabilizados pela política pública executada pela Área de Medicina Tradicional Indígena (AMTI), do Projeto Vigisus II/Fundação Nacional de Saúde (Funasa).

Acredito que, por meio dos enunciados dos diversos agentes socialmente posicionados no campo da saúde indígena, a categoria discursiva medicina tradicional consolida-se como objeto de políticas públicas. Porém, esse é um objeto semanticamente inacabado, diante da constante revisão de seus sentidos a cada vez que se discute o tema em situações comunicativas particulares. Se tudo aquilo que está sendo dito sobre a medicina tradicional indígena contribui para defini-la, então essa categoria se encontra em permanente construção dialógica, e os sentidos que a informam são emergentes.

As políticas públicas instauram realidades sociais e criam novos locais de cultura ao definirem os seus objetos e os públicos a quem elas se destinam. Ao concentrar o poder simbólico-administrativo de fazer existir por meio da nomeação oficial, o Estado define os conceitos empregados no escopo dessas políticas e institui dispositivos discursivos que transformam os seus objetos em híbridos culturais. No caso das políticas relacionadas às medicinas tradicionais, por exemplo, a validação científica dos conhecimentos e das práticas e a qualificação dos seus praticantes constituem dispositivos poderosos por meio dos quais são delineados os caminhos da sua integração aos sistemas de saúde nacionais.

As relações entre o Estado brasileiro e os organismos internacionais são importantes no processo de elaboração das políticas da tradição, cujo advento constitui um fenômeno moderno, pois tanto esses organismos quanto o Estado-nação são organizaçốes políticas características da modernidade. Existem, pois, vários alinhamentos e correspondências entre as perspectivas assumidas por este e por aqueles, e a dicotomia entre tradição e modernidade é estruturante dos seus discursos oficiais, na medida em que a primeira é definida nos termos da segunda ou em oposição a ela. Nesse caso a noção de tradição aplicada pelas políticas públicas é um constructo moderno!

Na perspectiva dessas políticas, a tradição é pensada como atributo de culturas estáticas, em que os conhecimentos e práticas tradicionais perduram por muitos anos, transmitidos de forma imutável de uma geração para outra. 
Por ser destituída de agência, a tradição precisaria, então, ser submetida ao escrutínio científico de modo a desenvolver o seu potencial e a validá-la cientificamente. Nos contextos discursivos oficiais, os povos indígenas são considerados "naturalmente tradicionais" e, em geral, passam a ser classificados pelas políticas públicas como povos e comunidades tradicionais.

Partilho da compreensão de Sahlins (1997a), que, em termos antropológicos, define tradição como os distintos modos pelos quais as transformações socioculturais se processam mediante as tentativas dos povos indígenas de incorporarem o sistema mundial ao seu próprio sistema de mundo. A transformação sociocosmológica, nesse caso, seria "necessariamente adaptada ao esquema cultural existente" (Sahlins, 1997a: 62). Porém, agregam-se a esses sentidos - os que informam as políticas públicas e os que fazem parte do arcabouço conceitual da antropologia - os significados que os próprios indígenas atribuem à tradição. No caso dos participantes dos eventos do Alto Juruá, a noção de tradição foi usada para contrastar diferenças e demarcar fronteiras entre as formas indígenas e os procedimentos não índios de cuidar da gestação e do parto. Aqui, essa categoria discursiva remete ao regime de etnicidade que pauta as relações interétnicas entre povos indígenas e o Estado brasileiro.

Se as políticas da tradição, ao irromperem em contextos locais particulares, podem reconfigurar os discursos localmente situados, então, os enunciados veiculados durante os encontros entre parteiras, pajés e AISs também foram suscetíveis a essas influências. Desses eventos comunicativos dialogicamente estruturados - que emergiram a partir das relações estabelecidas entre os povos indígenas, representados por suas lideranças, e o Estado, representado pela Área de Medicina Tradicional Indígena -, participaram representantes dos diferentes povos indígenas que habitam a região do Alto Juruá - Katukina, Kaxinawa, Yawanawa, Shanenawa, Nukini, Nawa, Jaminawa-Arara, Arara, Ashaninka e Kulina.

Além de tratar dos cuidados indígenas com a gestação e com o parto (dietas, uso de folhas e remédios tradicionais, rezas etc.), os discursos proferidos durante esses eventos também possibilitaram uma avaliação dos cursos de capacitação das parteiras indígenas tradicionais que aconteceram no Acre entre 2000 e 2004. A possibilidade de execução desses cursos foi instituída por uma política pública específica desenvolvida pelo Ministério da Saúde (MS), o Programa Trabalhando com Parteiras Tradicionais. Para os participantes dos encontros, esses cursos demarcaram as diferenças entre as formas indígenas de parir e de assistir os partos antes e depois do seu advento, bem como evidenciaram o contraste existente entre a forma do branco versus o modo do índio de gestar e de dar à luz.

Nesse contexto discursivo, foram usadas diversas categorias para expressar os múltiplos entendimentos dos participantes sobre os conhecimentos, as práticas e o papel dos cuidadores envolvidos com a gestação e o parto indígenas. A organização dialógica dos encontros permitiu que os sentidos atribuídos a essas 
categorias surgissem durante as conversações que ali foram realizadas. Alguns dos termos postos em debate e que tiveram seus sentidos desvelados no fluir dos diálogos foram: parteira, pajé, agente de saúde, pré-natal tradicional, branco, cultura etc. Ao emergir associada a essas outras categorias, a noção de medicina tradicional passou a fazer parte de uma constelação semântica particular. Considerar as associações entre as múltiplas categorias que conformam essa constelação e o contexto comunicativo de sua irrupção se faz fundamental para se compreender os sentidos que a medicina tradicional indígena assume nos enunciados sobre o tema.

É claro que várias nuances significativas dos discursos analisados escaparam à reflexão antropológica aqui empreendida. Isso se deve tanto à complexidade do fenômeno abordado, que, por ser processual, multidimensional e polissêmico, excede as tentativas de inscrição da ação social por meio da escrita, quanto à própria limitação imposta pela natureza desse empreendimento. Encontrei-me, pois, diante da difícil tarefa de, entre uma diversidade de vozes, escolher aquelas que se tornariam alvos de reflexão. Contudo, os discursos trazidos falam por si e extrapolam a própria análise realizada.

Se nos discursos oficiais nos deparamos com o processo de construção dos objetos das políticas da tradição por meio do poder simbólico-administrativo do Estado de fazer existir pela nomeação, as vozes indígenas nos eventos comunicativos do Alto Juruá se reportam aos processos de irrupção dessas políticas em contextos locais. Ao serem apropriados pelos povos indígenas, os discursos oficiais são postos a serviços dos seus interesses culturalmente situados - assim, estamos diante do fenômeno de indigenização da modernidade em uma de suas faces.

\section{A Área de Medicina Tradicional Indígena como contexto: entre o local e o global}

Este livro é um produto do projeto de pesquisa Análise Antropológica sobre os Dados Secundários do Banco de Dados da Área de Medicina Tradicional Indígena do Projeto Vigisus II/Funasa. ${ }^{2}$ As informações, resultados e lições aprendidas e produzidas no âmbito dos projetos de pesquisa-ação realizados pela AMTI entre 2004 e 2009 compõem esse banco de dados. ${ }^{3}$ No entanto, o fato de eu ter atuado como gerente da AMTI faz com que as reflexões aqui desenvolvidas também sejam fruto da minha experiência de gestão - lugar de onde a análise, como processo de produção de conhecimentos, foi efetivada.

Se por um lado ocupar essa posição no campo da saúde indígena me fez despertar para a importância de compreender os processos discursivos oficiais por meio dos quais as medicinas tradicionais - seus saberes, práticas e praticantes - se tornavam objetos de políticas públicas, por outro as vozes indígenas, aqui 
apresentadas como dados etnográficos, também emergiram a partir da minha atuação como gerente das ações realizadas pela AMTI. Assim, em virtude das implicações metodológicas que essa situação instaura, torna-se importante apresentar a AMTI como o contexto no qual o conhecimento antropológico aqui veiculado foi elaborado.

Visando a concretizar a diretriz da Política Nacional de Atenção à Saúde Indígena (PNASPI) que prevê a articulação dos serviços de saúde aos sistemas tradicionais indígenas de saúde, no decorrer do ano 2004 a Funasa criou a AMTI no âmbito do subcomponente Ações Inovadoras em Saúde do Projeto Vigisus II. O Vigisus - Projeto de Modernização do Sistema Nacional de Vigilância em Saúde foi efetivado via Acordo de Empréstimo n.7.227/1999 estabelecido entre o governo brasileiro e o Banco Mundial. Formado por dois componentes - Vigilância em Saúde e Saúde Indígena -, foi idealizado para ser implementado em três fases. Durante a fase 2, que esteve em vigência entre 2004 e 2009, o componente Vigilância em Saúde esteve a cargo da Secretaria de Vigilância em Saúde do Ministério da Saúde, ao passo que o componente Saúde Indígena ficou sob a responsabilidade da Funasa (Macedo, 2007).

O principal objetivo da AMTI era a elaboração de estratégias para a articulação entre as medicinas indígenas e o sistema oficial de saúde. Os demais objetivos eram: contribuir para a valorização, o fortalecimento, a manutenção e a atualização dos saberes e práticas tradicionais de cuidado com a saúde; produzir subsídios para a construção de políticas públicas de saúde indígena; colaborar para a consolidação do direito indígena à atenção diferenciada à sua saúde (Ferreira G Osório, 2007).

Para atingir esses objetivos, na AMTI se adotou a metodologia de pesquisa-ação (Thiollent, 2007) na realização de projetos participativos antropologicamente orientados, que associaram o processo de produção de conhecimentos às ações práticas propostas pelas lideranças indígenas representantes de diferentes povos do país. A pesquisa-ação foi considerada a estratégia metodológica adequada para implantar o plano de ação da AMTI, justamente por preconizar a participação de todos os interessados - gestores, pesquisadores, lideranças indígenas - nas distintas etapas de desenvolvimento do projeto: desde a elaboração da proposta e execução das atividades até a avaliação dos resultados alcançados.

Os projetos de pesquisa-ação foram viabilizados por meio de parcerias instituídas entre a AMTI e ONGs indígenas ou indigenistas. Cada projeto contou com uma equipe de execução composta por especialistas de distintas áreas do saber científico e por representantes indígenas. Dessa forma, ao mesmo tempo que as ações concretas propostas por lideranças indígenas eram viabilizadas, conhecimentos acerca dos fenômenos pautados pelo projeto eram produzidos. Ao instituir a participação como o contexto ético no qual tais ações deveriam ser realizadas, a AMTI transformou as equipes de execução dos projetos em comunidades interétnicas de comunicação (Cardoso de Oliveira G Oliveira, 1996), isto é, em instâncias em que 
as decisões, os acordos e as compreensões sobre a condução das atividades eram dialogicamente construídos entre os integrantes da equipe.

Entre 2004 e 2008, foram realizados oito projetos de pesquisa-ação, organizados em três eixos temáticos: sistemas de atenção ao parto e atenção à saúde materno-infantil; plantas medicinais e remédios tradicionais; xamanismo e intermedicalidade. Os eventos comunicativos que constituíram o contexto discursivo das falas aqui analisadas fizeram parte do Projeto Valorização e Adequação dos Sistemas de Parto das Etnias do Acre e Sul do Amazonas, executado em parceria com a ONG Instituto Olhar Etnográfico e com o movimento indígena da região.

O fato de a AMTI ter sido viabilizada por meio de um acordo de empréstimo entre o governo brasileiro e um organismo internacional - o Banco Mundial coloca-a em um espaço fronteiriço situado entre o global e o local: por um lado, constituiu-se uma política pública que utiliza a noção de tradição para qualificar seus objetos; por outro, ao se reconhecer os direitos dos povos indígenas sobre as suas medicinas tradicionais, instaurou-se um processo participativo para implantação do seu plano de ação envolvendo lideranças indígenas localmente situadas. Essa posição de fronteira ocupada pela AMTI é conflituosa justamente por estar localizada entre as tendências desenvolvimentistas dos organismos internacionais e do Estado-nação, que possibilitam a sua existência, e os interesses dos povos indígenas que participaram dos projetos por ela fomentados. De qualquer forma, ao possibilitar que os discursos oficiais irrompessem nas diferentes localidades onde ocorreram os projetos de pesquisa-ação, a AMTI contribuiu para conectar essas realidades locais às ordens nacionais e internacionais mais abrangentes.

Como gerente da AMTI, eu também ocupei uma posição de entremeio, situada entre as práticas discursivas oficiais e as vozes indígenas veiculadas desde as localidades em que estão inscritas. Mais uma vez, me vi como antropóloga das fronteiras a analisar discursos que surgem em eventos comunicativos viabilizados pelas decisões antropologicamente orientadas que tomei ao ocupar uma posição de gestão. Dessa maneira, esses discursos são efeitos de políticas públicas desenvolvidas em lugares distantes daqueles onde ocorreram e, ao irromperem nas localidades, instituíram novos locais de cultura, os quais requerem novos lugares do 'fazer antropológico', e o lugar de gestão se constitui em um desses lugares possíveis.

\section{Discursos como dados etnográficos}

Os discursos aqui analisados são compreendidos como dados etnográficos secundários e podem ser classificados em duas modalidades: os escritos (textos) e os falados (atos de fala). Os segundo capítulo trabalha, basicamente, com os textos dos organismos internacionais e das políticas públicas brasileiras, que empregam 
a noção de tradicional para qualificar os seus objetos. Para o desenvolvimento do capítulo que descreve os eventos comunicativos que constituíram o contexto de emergência das categorias discursivas aqui analisadas, foi utilizada a documentação pública produzida pela AMTI (relatórios, projetos, produtos de consultoria). Por fim, os capítulos que tratam dos discursos dos indígenas veiculados durante os encontros no Alto Juruá foram elaborados por meio das gravações realizadas pela equipe interétnica de execução desses eventos comunicativos. O material em áudio, em forma bruta, foi encaminhado pelo Instituto Olhar Etnográfico à AMTI como um dos produtos da consultoria por eles prestada. ${ }^{4}$

O registro em mídias eletrônicas e digitais permitiu o descolamento dos discursos do contexto de fala imediato e a sua reprodução em outros tempos e em outros espaços, tais como o deste livro. É preciso considerar que "todos os modos de armazenamento de informação são, simultaneamente, formas de comunicação, [que] rompem com a comunicação direta, exaustiva na interação humana nas culturas de tradição oral" (Giddens, 2008: 39). A transcrição dos áudios desses eventos, por sua vez, foi por mim realizada.

De qualquer forma, mesmo não estando presente nos eventos comunicativos que constituíram o contexto dos discursos aqui analisados, como gerente da AMTI exerci influência direta na configuração de tais situações, participando dos diálogos que aconteceram como um 'outro ausente'. O que permitiu o arranjo dessa complexa situação etnográfica é a própria situação de modernidade da qual fazemos parte.

O advento da modernidade arranca crescentemente o espaço do tempo fomentando relações entre outros 'ausentes', localmente distantes de qualquer situação dada ou interação face a face. Em condições de modernidade, o lugar se torna cada vez mais fantasmagórico: isto é, os locais são completamente penetrados e moldados em termos de influências sociais bem distantes deles. O que estrutura o local não é simplesmente o que está presente na cena; a 'forma visível' do local oculta as relações distanciadas que determinam sua natureza. (Giddens, 1991: 27)

Ao tomar tanto os discursos oficiais quanto as vozes indígenas pronunciadas em eventos localmente situados como dados etnográficos, busco elaborar uma descrição densa do fenômeno de emergência da medicina tradicional no campo das políticas públicas de saúde indígena. Desse modo, tento desvelar algumas complexas camadas de significados que informam esse fenômeno, expondo dimensões significativas que, ao estarem entrelaçadas e serem "simultaneamente estranhas, irregulares e inexplícitas", precisam primeiro ser apreendidas para, posteriormente, serem analisadas à luz da teoria antropológica (Geertz, 1989: 22). Ainda assim, o texto aqui apresentado constitui uma interpretação de interpretações outras. Tratandose, portanto, de uma ficção, no sentido de ser 'algo construído', uma leitura do que acontece em vários lugares interconectados pela realização das políticas da tradição. 


\section{Sobre os capítulos}

Este volume está organizado da seguinte forma: o primeiro capítulo "Estado-nação, poder e modernidade: revisitando conceitos" constitui-se de uma teórica sobre o papel dos Estados-nação e dos organismos internacionais, como organizações políticas características da modernidade, tanto na instituição de um mundo internacionalmente conectado quanto na configuração de realidades sociomédicas híbridas e translocais. Nele, analiso as influências que os organismos internacionais exercem no processo de elaboração das políticas públicas nacionais, bem como os poderes - simbólico e administrativo - exercidos e os dispositivos utilizados para ampliar o monitoramento reflexivo do Estado moderno. Por outro lado, considero os processos de produção dos híbridos culturais e de indigenização da modernidade levados a efeito pelos povos indígenas ao se apropriarem das políticas públicas a fim de manter a sua autonomia e reverter a seu favor o controle que o Estado passa a exercer sobre o mundo da vida de suas comunidades.

No segundo capítulo, "Os discursos oficiais e a emergência do tradicional como objeto de políticas públicas", apresento uma análise sintética dos discursos oficiais dos organismos nacionais e das políticas públicas, à luz da discussão teórica desenvolvida no primeiro capítulo. No Brasil, a elaboração das políticas públicas é influenciada pela dinâmica internacional - política e econômica - do sistema mundial. Diante disso, avalio o modo como essas influências propiciam o surgimento das políticas da tradição e de que maneira o tradicional passa a qualificar os objetos das políticas públicas, abrindo caminho para a emergência de objetos híbridos de políticas públicas.

No terceiro capítulo, "O contexto de emergência das vozes indígenas: os encontros de parteiras, pajés e AISs no Alto Juruá", apresento algumas informações a fim de caracterizar o contexto comunicativo que propiciou a emergência dos discursos indígenas sobre gestação e parto. Além disso, descrevo a organização e a programação das três reuniões de parteiras, pajés e AISs que aconteceram no Alto Juruá, bem como os participantes e os princípios estruturais que configuraram as interações estabelecidas entre eles.

No capítulo "Cursos, partos e parteiras tradicionais: apropriações indígenas dos conhecimentos e das coisas do branco", analiso, com base nos discursos veiculados nos eventos do Alto Juruá, os processos de apropriação e indigenização dos cursos de parteiras e, consequentemente, dos conhecimentos e dos materiais dos kits parteira neles distribuídos. As falas indígenas revelaram o quanto a realização desses cursos transf̧ormou a prática do "pegar menino" no âmbito das aldeias indígenas, contribuindo para alterar os papéis e a própria organização comunitária do cuidado com a gestação e o parto. Um dos principais efeitos desses cursos foi a criação do cargo de parteira tradicional em comunidades indígenas onde ele não existia. 
No capítulo "Os outros cuidadores: agência, intermedicalidade e gênero", considero os discursos que tratam dos papéis que os pajés e os AISs desempenham no cuidado com as gestantes, as parturientes e os recém-nascidos. Esses discursos expressam o quanto a prática desses cuidadores assume um caráter intermédico quando, no exercício de sua agência, fazem diversos arranjos entre saberes e procedimentos inscritos em diferentes horizontes socioculturais - o indígena e o biomédico. Por outro lado, também revelam que a agência desses cuidadores está marcada pela sua identidade de gênero. Faço, portanto, uma reflexão sobre a forma como as relações de gênero são determinantes na distribuição das incumbências de cada um dos agentes que cuidam da gestação e do parto, e como os cuidados dispensados nesse período extrapolam o domínio feminino, envolvendo a rede familiar e de parentesco em que a mulher está inserida.

No capítulo "Folhas, rezas e dietas: a emergência da medicina tradicional e do pré-natal indígena", enfoco os discursos que tratam das práticas de autoatenção durante a gestação e o parto, e que, além de garantir a saúde da mulher e do recém-nascido, também fazem parte dos processos socioculturais de produção de corpos e de pessoas aparentadas entre os povos indígenas do Alto Juruá. Para demonstrar que a noção 'medicina tradicional indígena' é constantemente recriada em seus sentidos nas múltiplas situações dialógicas em que é colocada em pauta, analiso como essa categoria discursiva e os múltiplos sentidos a ela associados emergem no decorrer dos encontros entre parteiras, pajés e agentes de saúde. Da mesma forma, considero a expressão 'pré-natal tradicional' uma categoria discursiva híbrida emergente, empregada pelos participantes para se referirem ao conjunto de práticas comunitárias utilizadas nos cuidados com a gestação.

No último capítulo, "Contrato, dádiva e a luta por reconhecimento", trato das reivindicações dos participantes das reuniões do Alto Juruá pela contratação remunerada das parteiras indígenas. Nesse contexto discursivo, as demandas por contrato estão associadas à luta pela conquista do reconhecimento pelo Estado da atuação das parteiras. Mas essa luta também encerra outra dimensão: a manutenção do reconhecimento das comunidades e das gestantes sobre a importância do trabalho das parteiras. Reflito sobre as implicações do contrato remunerado na organização dos cuidados comunitários com a gestação e o parto, na medida em que o reconhecimento profissional implica a regulamentação do ofício e a integração das parteiras ao sistema oficial de saúde. 


\section{Notas}

1 A questão das medicinas tradicionais indígenas se constituiu em um ponto de debate durante as quatro Conferências Nacionais de Saúde Indígena realizadas em 1986, 1993, 2001 e 2006.

2 O Projeto Análise Antropológica sobre os Dados Secundários do Banco de Dados da Área de Medicina Tradicional Indígena do Projeto Vigisus II/Funasa foi submetido e aprovado pelo Comitê de Ética em Pesquisa da Escola Nacional de Saúde Pública, Fundação Oswaldo Cruz (Ensp/Fiocruz).

3 Para maiores informações sobre os projetos de pesquisa-ação desenvolvidos pela Área de Medicina Tradicional Indígena, ver Ferreira G Osório, 2007.

4 O termo de referência que informava o contrato estabelecido entre o Projeto Vigisus II e as ONGs executoras dos projetos de pesquisa-ação previa a entrega dos registros audiovisuais brutos como um dos produtos da consultoria prestada à Área de Medicina Tradicional Indígena. As equipes interétnicas de execução dos projetos que negociaram com as comunidades indígenas as autorizações para o registro audiovisual das atividades. 
Os organismos internacionais ${ }^{1}$ e o Estado-nação são organizações modernas que mantêm relações de interdependência em um contexto mundialmente conectado. Se por um lado os organismos internacionais influenciam o processo de elaboração das políticas públicas nacionais, por outro o Estado se apoia nos discursos globalmente veiculados para instaurar um sistema de vigilância sobre as populações adstritas ao seu território. No Brasil, as recomendações internacionais exercem grande influência na criação das políticas públicas que qualificam os seus objetos pela categoria tradicional - medicina tradicional, medicina tradicional indígena, conhecimentos e práticas tradicionais, povos e comunidades tradicionais, parteiras tradicionais.

Para se compreender esse fenômeno tão característico da modernidade, convém revisitar algumas abordagens teóricas que podem contribuir para a reflexão sobre as influências que essas relações da esfera internacional e nacional exercem na reconfiguração e emergência de novos locais de cultura. E, igualmente, lançar luz sobre as estratégias elaboradas pelos povos indígenas para, ao se apropriarem e indigenizarem essas políticas, manterem a sua autonomia e autodeterminação, revertendo a seu favor o controle do Estado sobre as múltiplas dimensões que compõem o mundo da vida de suas comunidades translocais.

\section{O Estado-nação no contexto internacional}

Em sua face moderna, o Estado-nação pode ser definido como um tipo de organização política que mantém o monopólio administrativo sobre um território delimitado, "sancionado por lei e por um controle direto dos meios internos e externos de violência" (Giddens, 2008: 145). Um dos seus atributos é a capacidade de "monitoramento reflexivo dos aspectos da reprodução dos sistemas sociais subordinados ao seu domínio" (Giddens, 2008: 42-43). Para isso, o Estado opera com um aparato administrativo constituído por um conjunto de instituições de governo e por uma hierarquia de funcionários especializados. 
O Estado moderno, como organização política mundialmente difundida, está situado em um sistema mundial de Estados-nação que emerge mediante relações conflituosas e tensas historicamente estabelecidas na arena internacional: "A coordenação administrativa interna dos Estados-nação, desde o seu início, depende de condições monitoradas reflexivamente de natureza internacional. As relações internacionais são contemporâneas às origens dos Estados-nação" (Giddens, 2008: 30). Por sua vez, o surgimento do Estado moderno também é o que possibilita a criação dessa nova ordem internacional. "O termo 'internacional', de fato, somente tem o seu significado completo com a emergência dos Estados-nação que, por causa de seu caráter estritamente demarcado, fornece uma forma muito particular às questões 'internas' versus 'externas'" (Giddens, 2008: 191).

Portanto, mais do que significar a subordinação dos Estados a uma ordem mundialmente estabelecida, as relações mantidas com os organismos internacionais contribuem para a própria consolidação do Estado-nação, na medida em que criam as condições para o reconhecimento mútuo da soberania nacional (Giddens, 2008). A dicotomia entre nacional e internacional, assim, está superada: o Estado-nação, por sua virtude de moldar a ordem internacional (2008: 191), é a forma pela qual o mundo contemporâneo está politicamente organizado.

Todavia, o sistema mundial se estabelece por meio das conexões econômicas transnacionais e interdependentes propiciadas pela economia capitalista mundial, que se sustenta sobre o processo da mercantilização de produtos e da força de trabalho. É preciso dizer que o Estado-nação apresenta importantes alinhamentos institucionais com o capitalismo, desempenhando um papel importante na manutenção da ordem econômica: ao mesmo tempo que garante as condições políticas necessárias para a efetivação dos empreendimentos capitalistas, também depende desses empreendimentos para manter funcionando o seu aparato administrativo.

\section{Poder simbólico e poder administrativo: nomeação e vigilância estatal}

Se os organismos internacionais exercem influência sobre os Estados nacionais no desenvolvimento de suas políticas públicas, como é o caso das políticas da tradição, é porque ambos compartilham tanto o poder simbólico de instituir realidades ao conceituar, classificar e nomear os objetos de suas políticas quanto o poder administrativo de vigiar e controlar a conduta humana.

Segundo Bourdieu (2005), o poder de nomear e de fazer existir pela nomeação é uma das formas elementares do poder político. Na luta pelo monopólio do poder, os agentes tentam impor sua visão do mundo social por meio de determinadas 
estratégias simbólicas como, por exemplo, a nomeação. "A nomeação (...) pertence à categoria dos atos ou discursos 'oficiais', simbolicamente eficientes porque realizados em situação de autoridade, por pessoas autorizadas, por uma função ou um cargo atribuído pelo Estado" (Bourdieu, 2005: 143).

É justamente por ser o lugar de concentração e exercício do poder simbólico e por deter o monopólio para instituir taxonomias oficiais, que o Estado, ao mundo e a si próprio, produz e impõe as categorias de pensamento espontaneamente empregadas.

Ao enunciar, com autoridade, que um ser, coisa ou pessoa, existe em verdade em sua definição social legítima, isto é, é o que está autorizado a ser, o que tem direito a ser, o ser social que ele tem o direito de reivindicar, de professar, de exercer (por oposição ao exercício ilegal), o Estado exerce um verdadeiro poder criador. (Bourdieu, 1996: 114, grifo do original)

Por sua vez, é por meio dos discursos oficiais que o Estado exerce esse poder criador e impõe sobre o mundo os seus sistemas de classificação sob a aparência legítima das taxonomias oficiais. Desse modo, o mundo social em que os agentes interagem é instituído pelas políticas públicas.

O poder simbólico como poder de constituir o dado pela enunciação, de fazer ver e fazer crer, de confirmar ou de transformar a visão do mundo e, deste modo, a ação sobre o mundo, portanto o mundo. (...) Ele se define numa relação determinada - e por meio desta - entre os que exercem o poder e os que lhe estão sujeitos, quer dizer, isto é, na própria estrutura do campo em que se produz e se reproduz a crença. O que faz o poder das palavras (...), poder de manter a ordem ou de subvertê-la, é a crença na legitimidade das palavras e daquele que as pronuncia, crença cuja produção não é da competência das palavras. (Bourdieu, 2005: 15)

Entretanto, o Estado é estruturalmente heterogêneo, pois se constitui de diferentes redes de relações e alianças acessadas pelos agentes sociais que se movem de acordo com interesses e motivações distintos. No universo das políticas públicas, encontram-se agentes competindo e empregando suas próprias estratégias para tentar influenciar o campo e impor a sua visão de mundo. Assim, as estruturas sociais do campo se perpetuam, na medida em que os agentes sociais reproduzem as estruturas do poder de forma inconsciente. Como lembra Bourdieu, o Estado tanto se manifesta de forma objetiva, por meio de estruturas e mecanismos específicos, quanto molda subjetividades ao desenvolver estruturas mentais, esquemas de percepção e pensamento. "Dado que ela é resultado de um processo que a institui, ao mesmo tempo, nas estruturas sociais e nas estruturas mentais adaptadas a essas estruturas, a instituição instituída (...) apresenta-se com toda a aparência do natural" (Bourdieu, 1996: 97-98, grifo do original). 
Outra face do poder estatal, chamada por Giddens (2008) de poder administrativo e intimamente associada ao poder simbólico, refere-se aos mecanismos de vigilância que permitem o "monitoramento reflexivo da ação" dos agentes sociais que integram o Estado. "O poder administrativo é baseado na regulação e coordenação da conduta humana por meio da manipulação das situações nas quais elas ocorrem. A vigilância, assim como o código de informação, é um elemento essencial de tal poder" (Giddens, 2008: 72).

A vigilância tem dois aspectos distintos: a coleta, o armazenamento ${ }^{2}$ e o controle da informação, empregados para administrar as populações adstritas ao Estado; e a supervisão direta das atividades, exercida por alguns agentes que se encontram em posições de autoridade - os funcionários. Esses dois aspectos da vigilância estão intimamente relacionados, uma vez que o poder administrativo só poderá ser exercido se a informação puder ser aplicada diretamente na "supervisão das atividades humanas, de modo a destacá-las, em parte, de seu envolvimento com a tradição e com a vida da comunidade local" (Giddens, 2008: 73). Assim, a vigilância estatal passa a exercer influência sobre os mais íntimos aspectos da ação cotidiana dos agentes sociais.

O poder administrativo penetra agora cada vez mais nas minúcias da vida diária e nas mais íntimas ações pessoais e relações. Em uma época cada vez mais invadida pelos modos eletrônicos de armazenamento, coleta e disseminação de informação, as possibilidades de se acumular informação relevantes à prática do governo são quase infinitas. (...) A vigilância é a condição necessária do poder administrativo de Estados, quaisquer que sejam os fins a que esse poder se dirija. (Giddens, 2008: 320)

O que possibilita a efetivação da vigilância é a atuação de uma variedade de funcionários técnico-administrativos especializados responsáveis por realizar tarefas de domínio público. Na medida em que o poder administrativo do Estado se associa intimamente à burocracia, o poder exercido por esses especialistas e funcionários se configura como um poder burocrático (Giddens, 2008).

Em suas diferentes áreas de conhecimento, a ciência, na medida em que tem a tarefa de produzir informações que possam ser utilizadas com fins administrativos, também contribui para o monitoramento reflexivo do sistema social realizado pelo Estado. Como exemplos, pode se referir às estatísticas oficiais utilizadas pelo governo para planejar ações e monitorar resultados, bem como aos conhecimentos antropológicos que, por meio de relatos etnográficos, têm contribuído para a instrução dos processos de nomeação e classificação dos objetos das políticas públicas da tradição. No entanto, convém ressaltar que as ciências não tratam apenas de um "dado universo de objetos e eventos sociais, elas são constitutivas disso" (Giddens, 2008: 202). Assim, incrementam tanto o poder administrativo quanto o poder simbólico do Estado que, ao nomear, cria os objetos de políticas públicas. 
Os organismos internacionais também recorrem a modos de regulação reflexiva baseados no armazenamento e no controle da informação. O empreendimento levado a cabo pela Organização Mundial da Saúde (OMS), ao delinear "regulamentos sanitários internacionais de tipo extensivo e iniciar campanhas contra algumas das principais doenças" (Giddens, 2008: 278), permite compreender de que forma o monitoramento pode operar no campo da saúde pública. Nesse caso particular, o sistema de vigilância se dá sobre os corpos das pessoas mediante o esquadrinhamento biomédico de suas vidas cotidianas, o qual é levado a efeito por meio da implantação de serviços públicos de saúde que produzem informações detalhadas sobre a situação de saúde da população que atendem (Foucault, 1979).

\section{Cidadania, soberania e nacionalismo: a consolidação do Estado-nação}

Para concretizar os direitos de cidadania - civis, políticos e sociais/econômicos - e estendê-los a todos os segmentos da população adstrita ao seu território, o Estado precisa produzir informações, armazená-las e controlá-las. Contudo, aos direitos de cidadania estão associados modos específicos de vigilância que possibilitam o monitoramento reflexivo de muitas das dimensões do mundo da vida dos segmentos populacionais a quem eles se destinam. Portanto, para que determinados segmentos da população tenham acesso a esses direitos, é necessário que o Estado os faça existir por meio do ato da nomeação oficial e, ao mesmo tempo, produza informações que garantam o acesso aos benefícios governamentais destinados a esses segmentos. As informações coletadas pelo Estado sobre esses segmentos sociais podem beneficiar parte da população, "mas também podem ser um meio de regular suas atividades de um modo coordenado de acordo com as doutrinas políticas promulgadas pelas autoridades de Estado" (Giddens, 2008: 320-321).

No Brasil, a efetivação dos direitos de cidadania se dá pela criação e execução de políticas públicas específicas, voltadas para a inclusão social e política de segmentos populacionais antes marginalizados pelo poder público, tais como os povos indígenas e os povos e comunidades tradicionais. Para contemplar esses segmentos em seu escopo, as políticas precisam criar mecanismos que permitam classificar esses povos e comunidades e produzir informações científicas sobre eles. Nesse sentido, as políticas públicas também estão associadas a tipos de vigilância e constituem dispositivos por meio dos quais o poder simbólico e administrativo do Estado é exercido.

Aos direitos de cidadania está associada a ideia de soberania de Estado que abarca a sua comunidade política como um todo. Com a expansão do monitoramento reflexivo, a soberania se institui como uma nova ordem administrativa. 
Entretanto, um Estado somente pode ser soberano quando grande parte dos seus segmentos populacionais "dominam uma série de conceitos relativos à soberania (...) e se encontram conscientes de sua vinculação a uma comunidade política e aos direitos e obrigações que tal associação confere" (Giddens, 2008: 227-228).

Com o advento do Estado-nação, os Estados têm uma unidade administrativa organizada territorialmente (...). Entretanto, esta unidade não pode permanecer puramente administrativa, porque a coordenação real das atividades envolvidas pressupõe elementos de homogeneidade cultural. A extensão de comunicação não pode ocorrer sem o envolvimento 'conceitual' de toda a comunidade como uma coletividade informada. O Estado-nação é uma 'comunidade conceitual'. (Giddens, 2008: 236-237, grifo do original)

As políticas públicas, nesse caso, contribuem para instituir a comunidade conceitual necessária à existência do próprio Estado-nação e configuram formações discursivas hegemônicas que integram a ideologia disseminada pelo Estado moderno no contexto da sociedade nacional. A disseminação da informação, por sua vez, se dá por meio do próprio aparato administrativo governamental, que disponibiliza ao domínio público mensagens de distintas ordens.

\section{A modernidade como contexto: o global e o local}

O sistema mundial, ao instituir a globalização como processo, contribui para redefinir as relações mantidas entre povos e culturas diferentes, para intensificar a produção de híbridos culturais e para complexificar o mapa das interações estabelecidas entre local e o mundial, entre o tradicional e o moderno. A emergência de um sistema mundial é um fenômeno marcadamente moderno. Em uma primeira aproximação, Giddens (1991: 11) entende a modernidade como o "estilo, costume de vida ou organização social que emergiram na Europa a partir do século XVII e que ulteriormente se tornaram mais ou menos mundiais em sua influência". Logo em seguida, reconhece a condição multidimensional da modernidade, configurada pelas três instituições - o Estado-nação, o capitalismo e o industrialismo - que a constituem, e identifica como as suas principais características os processos de separação do tempo e do espaço e sua padronização; o desencaixe dos sistemas sociais que dilatam o distanciamento tempo-espaço; e a reordenação reflexiva das relações em razão das inserções contínuas de conhecimentos no mundo da vida (Giddens, 1991).

As organizações modernas são capazes de conectar o local e o global, afetando a vida das pessoas em distintas partes do mundo. Para a compreensão desse fenômeno, a ideia de desencaixe, ${ }^{3}$ entendido como "deslocamento das relações 
sociais de contextos locais de interação e sua reestruturação através de extensões indefinidas de tempo-espaço", é fundamental (Giddens, 1991: 29). Por sua vez, aquilo que é deslocado dos contextos locais passa por um processo de reencaixe, na medida em que há uma "reapropriação ou remodelação de relações sociais desencaixadas de forma a comprometê-las (...) a outras condições locais de tempo e lugar" (Giddens, 1991: 84). Esse processo de reencaixe permite a reconfiguração da localidade:

O lugar se tornou fantasmagórico porque as estruturas através das quais ele se constitui não são mais organizadas localmente. O local e o global, em outras palavras, tornaram-se inextricavelmente entrelaçados. (...) A comunidade local é uma expressão localmente situada de relações distanciadas. (Giddens, 1991: 110)

Nesse caso, a modernidade é globalizante justamente por complexificar as relações mantidas no local (relações de copresença) e aquelas que se dão mediante a distância (conexões de presença e ausência). Na medida em que a modernidade desloca e torna fantasmagóricos os lugares, permite a inserção dos agentes sociais em cenários culturais e informativos globalizados.

A globalização pode assim ser definida como a intensificação das relações sociais em escala mundial, que ligam localidades distantes de tal maneira que acontecimentos locais são modelados por eventos ocorrendo a muitas milhas de distância e vice-versa. Este é um movimento dialético, porque tais acontecimentos locais podem se deslocar numa direção inversa às relações distanciadas que os modelam. A transformação local é tanto uma parte da globalização quanto a extensão lateral das conexões sociais através do tempo e do espaço. (Giddens, 1991: 69-70, grifo do original)

Se, por um lado, é inerente à modernidade o contraste com a tradição, por outro, os discursos e as definições sobre a tradição constituem um fenômeno reflexivo, marcadamente moderno, que desempenha um papel fundamental na reprodução do sistema social moderno por possibilitar que as práticas sociais sejam analisadas e revisadas conforme as informações sobre elas produzidas. Nesse caso, "não se sanciona uma prática por ela ser tradicional; a tradição pode ser justificada, mas apenas à luz do conhecimento, o qual, por sua vez, não é autenticado pela tradição" (Giddens, 1991: 45). A ciência moderna desempenha papel fundamental na reprodução dos sistemas sociais: justificar e validar a tradição de modo a transformá-la. 


\section{A diferença cultural e a produção dos híbridos}

A globalização instaura a ocidentalização do mundo, uma vez que importa não só mercadorias, mas também valores e estilos de vida ocidentais para regiões do globo antes distante da modernidade. Dessa forma, ela desencadeia processos de hibridação em que "estruturas ou práticas discretas, que existiam de forma separada, se combinam para gerar novas estruturas, objetos e práticas" (Canclini, 2003: 22).4

Para compreender a emergência dos híbridos em um mundo cada vez mais interconectado, convém observar de que forma as diferenças culturais se articulam nas interações estabelecidas entre distintos grupos sociais, e entre estes e o Estado. Se as diferenças culturais são instituídas e se tornam visíveis por meio das condições de enunciação, então o sujeito da diferença, além de ser fundamentalmente dialógico, é constituído na própria relação com o Outro. A fronteira, como espaço liminar, um entrelugar, demarca os domínios dessas diferenças, confunde os termos e propicia a emergência de novos arranjos: os híbridos culturais.

Os embates de fronteira acerca da diferença cultural têm tanto possibilidade de serem consensuais quanto conflituosos; podem confundir nossas definições de tradição e modernidade, realinhar as fronteiras habituais entre o público e o privado, o alto e o baixo, assim como desafiar as expectativas normativas de desenvolvimento e progresso. (Bhabha, 2005: 20-21)

O discurso colonial sobre a alteridade, veiculado pelo Estado-nação, em geral, pauta-se sobre uma noção fixa e paradoxal instituída como signo da diferença cultural, étnica ou racial: por um lado, a fixidez remete a rigidez e a ordem imutável; por outro, representa desordem, degeneração e repetição (Bhabha, 2005). Dessa forma, o estereótipo se apresenta como um dispositivo empregado pelo discurso oficial no processo de construção das subjetividades coloniais e no exercício do poder. "O estereótipo (...) é uma simplificação porque é uma forma presa, fixa, de representação que, ao negar o jogo da diferença (...), constitui um problema para a representação do sujeito em significações de relações psíquicas e sociais" (Bhabha, 2005: 117).

O exercício do poder simbólico-administrativo pelo Estado brasileiro por meio de suas políticas públicas também está impregnado do poder colonial. Ao nomear os objetos das políticas da tradição, o Estado tende a transformar as diferenças étnicas e culturais em estereótipos, apoiando-se de forma ambivalente ora no reconhecimento ora no repúdio a essas mesmas diferenças - sejam culturais, étnicas ou raciais. A estratégia utilizada pelo poder colonial prevê a criação de um espaço, sustentado pela produção de conhecimentos estereotipados e pelas práticas de vigilância para a inclusão subordinada dos 'povos sujeitos' à sociedade majoritária. 
Apesar do jogo de poder no interior do discurso colonial e das posicionalidades deslizantes de seus sujeitos (...), estou me referindo a uma forma de governamentalidade que, ao delimitar uma 'nação sujeita', apropria, dirige e domina suas várias esferas de atividade. Portanto, (...) o discurso colonial produz o colonizado como uma realidade social que é ao mesmo tempo um 'outro' e ainda assim inteiramente apreensível e visível. (...) Ele emprega um sistema de representação, um regime de verdade, que é estruturalmente similar ao realismo. (Bhabha, 2005: 111)

Outro dispositivo empregado pelo discurso oficial é o da mímica colonial, que tem a virtude de instaurar entre os grupos minoritários colonizados processos de imitação e de repetição dos costumes e hábitos do colonizador. Como uma forma de diferença, a mímica colonial tem na reforma do Outro o seu objetivo, por isso ela

é o desejo de um Outro reformado, reconhecível, como sujeito de uma diferença que é quase a mesma, mas não exatamente. (...) A mímica é assim, o signo de uma articulação dupla, uma estratégia complexa de reforma, regulação e disciplina que se apropria do Outro ao visualizar o poder. A mímica é também o signo do inapropriado, porém uma diferença ou recalcitrância que ordena a função estratégica dominante do poder colonial intensifica a vigilância e coloca uma ameaça imanente tanto aos saberes 'normalizados' quanto aos poderes disciplinares. (Bhabha, 2005: 127)

Ao veicular os saberes oficiais do Estado que operam com estereótipos e com o dispositivo da mimese colonial, as políticas públicas contribuem para a produção de sentidos e de relações de poder que articulam as diferenças em uma ordem hierárquica colonizadora. À ciência cabe o importante papel de justificar e legitimar essas hierarquias instituídas pelos governos modernos e coloniais. "É no território dessa coexistência que as estratégias de hierarquização e marginalização são empregadas na administração de sociedades coloniais" (Bhabha, 2005: 127-128).

Entretanto, os símbolos coloniais produzidos pelos discursos oficiais, ao deslizarem pelas fronteiras das diferenças culturais e serem apropriados pelos grupos minoritários colonizados, à medida que passam a compor outros contextos discursivos, assumem novos sentidos e valores. A hibridização dos discursos surge, assim, como efeito do poder colonial que produz as diferenças de acordo com as quais são definidos os termos que pautam as relações de alteridade.

O hibridismo é uma problemática de representação e de individuação colonial que reverte os efeitos da recusa colonialista, de modo que outros saberes 'negados' se infiltrem no discurso dominante e tornem estranha a base de sua autoridade - suas regras de reconhecimento. (...) O objeto híbrido conserva a semelhança real do símbolo autorizado, mas reavalia sua presença, resistindo a ele. (...) A cultura, como espaço colonial de intervenção e agonismo, como traço 
do deslocamento de símbolo, pode ser transformada pelo desejo imprevisível e parcial do hibridismo. Destituídos de sua presença plena, os saberes da autoridade cultural podem ser articulados com as formas de saberes 'nativos' ou confrontados com aqueles sujeitos discriminados que eles têm de governar, mas que já não podem representar. (...) A exposição do hibridismo - sua 'replicação' peculiar - aterroriza a autoridade como o ardil do reconhecimento, sua imitação, seu arremedo. (Bhabha, 2005: 166-167)

Portanto, é o espaço fronteiriço que configura as relações coloniais mantidas entre o Estado-nação e as populações subordinadas. Esse entrelugar, que esvazia o conteúdo semântico original do símbolo oficial, possibilita a sua emergência como um híbrido cultural. O objeto híbrido está articulado "com uma série de saberes e posicionalidades diferenciais, que tanto afastam sua 'identidade' como produzem novas formas de saber, novos modos de diferenciação, novos lugares de poder" (Bhabha, 2005: 173). Nesse caso, é importante observar com atenção os diferentes significados veiculados por símbolos aparentemente semelhantes, mas que informam experiências culturais diversas e fundam novos locais de cultura ao serem reinscritos em contextos sociais particulares. Aqui, o híbrido surge como símbolo deslocado que não deixa de trazer algo do seu lugar de origem.

\section{Indigenização da modernidade e translocalidade}

Se políticas públicas constituem um dispositivo empregado para incrementar o monitoramento reflexivo exercido pelo Estado, também são apropriadas pelos grupos subordinados e colocadas a serviço dos seus próprios objetivos de desenvolvimento. Os processos de apropriação dos símbolos e dos discursos do colonizador propiciam a emergência de híbridos culturais e fundam novos locais de cultura, que tendem a escapar do controle administrativo governamental.

Quando fazem exigências interculturais, híbridas, os nativos ao mesmo tempo desafiam as fronteiras do discurso e modificam sutilmente seus termos, estabelecendo outro espaço especificamente colonial de negociação da autoridade cultural. E o fazem sob o olho do poder, através da produção de saberes e posicionalidades 'parciais' em conformidade com o hibridismo. Tais objetos de saberes tornam os significantes da autoridade enigmáticos. (...) Eles modificam suas condições de reconhecimento enquanto mantêm sua visibilidade. (Bhabha, 2005: 172)

Giddens (2008) define como "dialética do controle" a habilidade dos grupos subalternos de criarem contraestratégias e esferas de autonomia próprias frente aos mecanismos de poder utilizados pelo Estado-nação. Essa dialética do controle 
só se faz possível porque o poder, de fato, é um atributo dos agentes sociais: ser um agente é ter poder.

Todas as formas de domínio têm 'aberturas' que podem ser utilizadas pelos que estão em posições subordinadas para influenciar as atividades daqueles que detêm o poder sobre eles. Uma das consequências disso é que as tecnologias de poder - em outras palavras, procedimentos formalizados de domínio - raramente funcionam, se é que isso ocorre, com a 'firmeza' que, diante dos fatos, eles parecem possuir. (Giddens, 2008: 37)

No caso dos povos indígenas, a apropriação dos símbolos e dos discursos oficiais constitui um meio de incorporação do sistema mundial a universos sociocosmológicos particulares. Eis o fenômeno denominado indigenização da modernidade, configurado pelos processos de ampliação de mundo, culturalismo e developman, conceito desenvolvido por Sahlins (1997a) para se referir às perspectivas indígenas sobre o desenvolvimento relacionadas aos fenômenos de intensificação ou florescimento cultural. Em suas próprias palavras,

Eu prefiro escrevê-la tal como ela soa realmente em inglês: 'developman', 'desenvolver (o) homem', isto é, o desenvolvimento das pessoas. (...) O desenvolvimento se manifesta caracteristicamente para os povos da Nova Guiné como uma expansão dos poderes e valores tradicionais, sobretudo através da ampliação das trocas cerimoniais e de parentesco. (...) Refere-se a um processo (...) no qual os impulsos comerciais suscitados por um capitalismo invasivo são revertidos para o fortalecimento das noções indígenas da boa vida. (Sahlins, 1997a: 59-60)

Ainda de acordo com o antropólogo americano, as relações estabelecidas entre os povos indígenas e as organizações da modernidade - Estado-nação e mercado - podem conduzir a um processo de intensificação cultural e expansão das instituições tradicionais indígenas. É claro que as sociedades indígenas são transformadas por essa relação, mas tenderão a se ajustar à nova ordem por meio das instituições socioculturais preexistentes que permanecem ao adquirir novos valores e significados. Isso acontece porque os sistemas culturais locais são a base sobre a qual os povos indígenas interpretam e organizam os objetos, recursos e serviços advindos das relações estabelecidas com o sistema mundial. Ao se apropriarem dos objetos ocidentais e revertê-los para o fortalecimento das noções indígenas de boa vida, "os povos indígenas locais experimentaram um developman de sua cultura tradicional desde e por meio de sua articulação com o sistema mundial moderno" (Gregory apud Sahlins, 1997a: 63). Nesse caso, a tradição passa a ser entendida como os diferentes modos em que a transformação ocorre de maneira adaptada ao sistema sociocultural previamente estabelecido (Sahlins, 1997a). 
No fenômeno identificado como culturalismo, a cultura passa a ser empregada pelos povos indígenas como um dispositivo discursivo e político na luta pela sobrevivência e reprodução cultural. Os indígenas desejam incorporar a ordem mundial em suas próprias ordens cosmológicas e, para isso, precisam domesticar e controlar as forças de sua transformação histórica. Nesse caso, a defesa da cultura está vinculada ao "desejo de manter e expandir o acesso às inovações técnicas, médicas e demais 'benefícios' materiais do sistema mundial" (Sahlins, 1997b: 132).

A luta pela autodeterminação indígena mostra um esforço para assumir o controle da administração oficial (...) transformando-a em fonte de recursos políticos para os povos nativos. Essa luta inclui a substituição de administradores 'brancos' por pessoal nativo, a busca de maior controle político e econômico sobre a terra e os recursos naturais, e a invenção de um novo lugar simbólico dentro das estruturas estatais, conferindo aos nativos o estatuto especial de 'cidadãos com direitos adicionais' (...). Os povos indígenas desejam ter pleno acesso a todas as áreas da sociedade, ao abrigo de preconceitos e discriminações, como os demais cidadãos. Mas eles também reclamam um estatuto especial de originariedade com seu próprio conjunto de direitos e obrigação. (Turner apud Sahlins, 1997b: 127)

Os processos de ampliação do mundo, por sua vez, ocorrem quando os membros das comunidades nativas locais migram para grandes centros urbanos, mantendo seus laços de parentesco com a terra de origem. Esse fenômeno permite a conformação de sociedades transculturais dispersas, porém vinculadas à terra natal por meio de uma contínua circulação de pessoas, ideias, objetos e dinheiro. A incorporação de bens, objetos e experiências advindas do mundo externo, geralmente, incrementa os poderes e as relações locais e possibilita que "as práticas e relações tradicionais ganhem novas funções e talvez novas formas situacionais" (Sahlins, 1997b: 114).

A irrupção do sistema mundial em contextos locais, quando apropriado e indigenizado pelos povos indígenas, faz surgir múltiplas formas culturais translocais. Essas configurações translocais são produtos de distintas relações estabelecidas no âmbito local e também entre o local e o global. Nesse processo, alguns agentes que transitam entre o local e o global desempenham o papel de mediadores da transformação social. "Assim como a modernidade não é a mesma em todas as partes, a translocalidade produz formas particulares que diferenciam um grupo dos outros" (Ayora Diaz, 2007: 141, tradução minha).

Para analisar as dinâmicas da translocalidade, Ayora Diaz (2007) se deteve num projeto de medicina tradicional indígena realizado em Chiapas pelo governo mexicano em parceria com organismos internacionais e organizações não governamentais. A noção de medicina tradicional operacionalizada por esse projeto estava pautada em uma ideia essencializada e estereotipada da figura indígena. Assim, a heterogeneidade dos saberes médicos indígenas foi reduzida ao uso de 
plantas medicinais, ao mesmo tempo que as demais práticas fundamentadas em princípios espirituais-cosmológicos diferenciados foram marginalizadas e desqualificadas pela ciência.

Pode entender-se a emergência, fomento e consolidação da medicina herbolária na região como uma forma de translocalidade gestada no âmbito das relações globais-locais que é, por sua vez, mediada por não indígenas que buscam fortalecer a localidade das comunidades de Chiapas subordinando-as ao código universal da racionalidade moderna da ciência nor-atlântica. (Ayora Diaz, 2007: 146-147, tradução minha)

Nesse caso exemplar, pode-se perceber a forma como as apropriações indígenas dos projetos governamentais da área da saúde possibilitam que práticas terapêuticas assumam configurações translocais delineadas com base em distintas experiências dos agentes sociais. "Cada grupo incorporou, apropriou, adaptou e adotou elementos de outros saberes que em cada momento de sua história tem encontrado significado" (Ayora Diaz, 2007: 148, tradução minha). Portanto, ao emergir a partir do encontro colonial estabelecido entre os povos indígenas e os múltiplos agentes que representam as organizações do mundo moderno, essas práticas assumem um caráter intermédico.

\section{Intermedicalidade e práticas de autoatenção}

Se o poder biomédico, ${ }^{5}$ como uma das faces do poder simbólico-administrativo exercido pelo Estado e pelos organismos internacionais, informa as práticas discursivas nacionais e internacionais relacionadas às medicinas tradicionais indígenas, é nos locais onde acontecem os encontros intermédicos entre os agentes ocidentais biomedicamente orientados e os povos indígenas, como o descrito por Ayora Diaz (2007), que as relações de poder assimétricas são instituídas. No entanto, é na zona de contato - espaços dos encontros coloniais, onde colonizados e colonizadores em suas interações, entendimentos e práticas estabelecem relações de poder radicalmente assimétricas (Pratt apud Follér, 2004) -, na qual as influências do desenvolvimento médico e a agência desses povos se fundem, que os povos indígenas, no exercício de seu poder criativo, se apropriam da biomedicina e recriam a sua realidade sociomédica, incorporando aos seus universos socioculturais alguns dos elementos provenientes da medicina ocidental.

Quando incorporada aos universos sociomédicos indígenas, a biomedicina é indigenizada, passando a ser controlada pelos praticantes das medicinas tradicionais. Assim, tais especialistas empoderam a sua própria técnica médica por meio de um processo de atualização e transformação dos conhecimentos e práticas com os 
quais operam. A indigenização da biomedicina implica tanto a aceitação quanto a resistência dos povos indígenas ao poder e à ideologia biomédica. "Trata-se de um projeto de negociação e renegociação, resistência cultural e ilustração da formação de uma identidade indígena como estado dinâmico e transitório" (Follér, 2004: 144).

Portanto, se por um lado temos os esforços dos agentes coloniais para cientificizar os sistemas sociomédicos indígenas - as medicinas tradicionais, por outro os povos indígenas indigenizam a biomedicina, mediante a apropriação dos procedimentos e recursos da medicina ocidental disponibilizados no contato estabelecido com o sistema mundial, aqui representado pelo modelo médico hegemônico.

Por isso, pode-se dizer que o fenômeno da indigenização da modernidade, ao ser constitutivo do campo interétnico da saúde indígena, o transforma em uma zona de contato intermédica, na qual a medicina científica e os sistemas sociomédicos indígenas interagem na prática e na teoria - local fronteiriço que propicia a emergência de medicinas indígenas híbridas.

Se as relações entre o sistema mundial e as múltiplas localidades permitiram que diferentes modelos de atenção à saúde ${ }^{6}$ surgissem como formas médicas híbridas e translocais, são os agentes indígenas os responsáveis por indigenizar esses modelos e articulá-los entre si mediante o uso que eles fazem de tais recursos no decorrer de sua vida cotidiana (Menéndez, 2003: 189). De acordo com o autor, o núcleo da articulação dos modelos de atenção são as práticas de autoatenção, na medida em que é por meio delas que os sujeitos exercem a sua agência a fim de manter e recuperar a saúde.

Por autoatenção nos referimos (...) às representações e práticas que a população utiliza no nível do sujeito e grupos sociais para diagnosticar, explicar, atender, controlar, aliviar, aguentar, curar, solucionar ou prevenir os processos que afetam sua saúde em termos reais ou imaginários, sem a intervenção central, direta e intencional de curadores profissionais, ainda quando estes possam ser a referência da atividade de autoatenção; de tal maneira que a autoatenção implica decidir a autoprescrição e o uso de um tratamento de forma autônoma ou relativamente autônoma. É dizer que a autoatenção se refere às representações e práticas que manejam os sujeitos e grupos a respeito de seus padeceres, incluindo as induzidas, prescritas ou propostas por curadores das diferentes formas de atenção, porém que, em função de cada processo específico, das condições sociais ou da situação dos sujeitos, conduz a que uma parte deste processo de prescrição e uso se autonomize. (Menéndez, 2003: 198)

A autoatenção tem dois níveis: um amplo e outro restrito. No nível amplo, as formas de autoatenção são empregadas para assegurar a reprodução biossocial dos sujeitos e grupos sociais; em sentido estrito, remetem-se às representações e práticas aplicadas intencionalmente ao processo saúde-enfermidade-atenção (Menéndez, 2003). As articulações que os distintos grupos sociais fazem das diferentes 
formas de atenção disponíveis em seu campo de ação propiciam tanto a emergência das medicinas híbridas quanto das práticas e agentes intermédicos.

A autoatenção quase sempre é a primeira atividade que o microgrupo realiza a respeito dos padeceres detectados, e essa atividade não inclui inicialmente nenhum curador profissional, ainda quando possa inicialmente consultar a algum membro dos espaços familiares e sociais imediatos, porém que não desempenha nenhuma atividade como curador profissional. (...) A decisão de ir consultar um curador profissional, e uma parte das atividades que se realizam logo da consulta constituem também parte do processo de autoatenção. (Menéndez, 2003: 201)

De qualquer forma, as articulações estabelecidas pelos agentes sociais entre os distintos modelos de atenção não deixam de ser informadas por uma relação hierárquica entre hegemonia e subalternidade. A expansão da biomedicina afeta a relação com os outros modelos de atenção vigentes, subalternizando-os. Nesse caso, um dos efeitos da expansão biomédica é a medicalização não só das doenças, mas também de comportamentos dos grupos sociais subordinados. A medicalização representa, assim, um processo de colonização de corpos e de subjetividades, pois esse efeito

implica converter em enfermidade toda uma série de episódios vitais que são parte dos comportamentos da vida cotidiana dos sujeitos e que passam a ser explicados e tratados como enfermidade quando previamente só eram acontecimentos cotidianos. Este processo implica não só que os sujeitos e grupos sociais assumam tais acontecimentos cotidianos em termos de enfermidade (...) mas sim que passem a explicá-los e atendê-los, em grande medida através de técnicas e concepções biomédicas. (Menéndez, 2003: 193)

Portanto, mesmo que os agentes sociais exerçam o seu poder criativo ao indigenizarem a biomedicina, os símbolos ou objetos coloniais ainda trazem algo de sua sociedade de origem. Se as políticas públicas de saúde, sustentadas sobre o paradigma biomédico, estão impregnadas do poder simbólico-administrativo do Estado-nação, então, a medicalização de corpos e de comportamentos constitui uma forma de colonização do mundo da vida das comunidades indígenas, um efeito perverso instituído pela irrupção das políticas públicas em contextos locais.

\section{Discurso, diálogo e a emergência da cultura}

Já que, na reflexão sobre os processos de emergência da medicina tradicional no campo das políticas públicas, consideram-se, por um lado, os discursos oficiais veiculados pelos organismos internacionais e pelo Estado brasileiro e, por 
outro, os enunciados indígenas localmente situados dos participantes dos encontros de parteiras, pajés e agentes indígenas de saúde do Alto Juruá, convém retomar os conceitos de discurso e de emergência dialógica da cultura.

No momento da manifestação da linguagem, o discurso configura um tipo de ação social significativa. Os sentidos que o informam são definidos tanto pela intenção do interlocutor ao dizer algo quanto pelo modo como o enunciado é construído. Se assim for, então o discurso é conformado pela dialética entre acontecimento e significado:

O acontecimento é a experiência entendida como expressão, porém é também o intercâmbio intersubjetivo em si e a comunicação com o receptor. O que se comunica no acontecimento da fala não é a experiência do falante como esta foi experimentada, mas sim seu sentido. A experiência vivida permanece em forma privada, porém seu significado, seu sentido, se faz público através do discurso. (...) Podemos dizer que a linguagem é em si o processo pelo qual a experiência privada se faz pública. (Ricoeur, 1995: 9-10, tradução minha)

O discurso, sempre dirigido a um destinatário, só existe na forma de enunciados concretos feitos por interlocutores individuais: os sujeitos da fala. Portanto, é a presença de um falante e de um ouvinte que institui o diálogo como estrutura fundamental do discurso (Ricoeur, 1995; Bakhtin, 1980). "O acontecimento não é somente a experiência tal como é expressa e comunicada, mas sim o intercâmbio intersubjetivo em si, o acontecer do diálogo. A instância do discurso é a instância do diálogo (...) que conecta dois acontecimentos: falar e escutar" (Ricoeur, 1995: 30, tradução minha).

O contexto dialógico do discurso tem um papel fundamental na construção do sentido veiculado. Os enunciados apenas adquirem relevância semântica quando estão ancorados nos contextos em que acontecem como atos de fala, e sempre estão relacionados a outros aos quais se refere. Dessa forma, todo o discurso é dialogicamente orientado, já que falar sobre um determinado assunto, geralmente, significa se remeter ao que já foi dito de diferentes formas. A um único tema pode estar vinculado pontos de vistas e visões de mundo diversos, não necessariamente convergentes, mas que entram em diálogo ao se encontrarem em um mesmo campo comunicativo.

Visão de mundo, tendências, ponto de vistas e opiniões sempre tem expressão verbal. Tudo isso é o discurso de outros refletido no enunciado. Até a mais leve alusão ao enunciado de outros coloca o discurso num circulo dialógico. (...) Um enunciado está ligado no canal da comunicação discursiva e não pode ser separado das ligações precedentes que o determinam. (Bakthin, 1980: 73, tradução minha)

A noção de dialogicidade, portanto, é central na definição do conceito de discurso, pois remete às relações que os enunciados mantêm uns com outros no 
contexto das relações interdiscursivas - os produzidos anteriormente e os que ainda serão proferidos por destinatários reais ou virtuais em resposta ao enunciado do locutor. Até mesmo "enunciados longamente desenvolvidos, ainda que emanem de um interlocutor único (...) são monológicos apenas em sua forma exterior, mas em sua estrutura interna, semântica e estilística, são essencialmente dialógicos" (Volochinov apud Charaudeau G Maingueneau, 2006: 161).

O conceito de formação discursiva desenvolvido por Foucault (2005) também remete à dimensão dialógica como constitutiva do discurso ao reafirmar que os enunciados estão sempre relacionados a outros já proferidos:

Seja para repeti-la, seja para modificá-las, seja para se opor a elas, seja para falar de cada uma delas; não há enunciado que, de uma forma ou de outra, não reatualize outros enunciados. O enunciado se delineia em um campo enunciativo onde tem lugar e status, que lhe apresenta relações possíveis com o passado e que the abre um futuro eventual. (...) Sempre um enunciado faz parte de uma série ou de um conjunto desempenhando um papel no meio dos outros, neles se apoiando e deles se distinguindo. (Foucault, 2005: 111)

Mas o diálogo é tanto o fundamento da linguagem e da comunicação humana quanto um gênero de fala específico ou um conjunto de gêneros dialógico-conversacionais (Bakhtin, 1980). Tal qual o gênero de fala, o diálogo pode ser definido como "um modo cultural e historicamente definido de conceber certas transações verbais e tem, enquanto tal, uma força retórica considerável" (Crapanzano, 1991: 60). Por meio do diálogo, mundos são constituídos e compartilhados, permitindo às pessoas que participam dele chegar a um entendimento comum sobre o tema em pauta. "O diálogo cria um mundo ou, pelo menos, uma compreensão das diferenças entre dois mundos" (Crapanzano, 1991: 61), e, por estar aberto ao processo comunicativo, tem uma função integradora, permitindo que a forma da interação seja definida durante a conversa.

O diálogo, como evento da linguagem por meio da qual se dá o entendimento mútuo, requer que os sujeitos da fala estejam abertos às questões e intenções de seus interlocutores. O diálogo é "uma travessia, um compartilhar, senão de uma base de compreensão mútua, ao menos de uma concepção comunicativa comum, uma aproximação, uma fusão" (Crapanzano, 1991: 60), e exige que "os participantes se entendam, que estejam um com o outro e que se deixem conduzir pelo objeto da conversa. Na verdadeira conversa, surge algo novo para os participantes e, de certo modo, independente deles" (Gadamer apud Crapanzano, 1991: 62). Mas, se o diálogo desempenha uma função integradora, também pode assumir um caráter tenso, agonístico e de oposição (Crapanzano, 1991: 66).

De qualquer forma, se mundos plenos de sentido são construídos no fluxo dialógico, as culturas, como sistemas de significados, também são continuamente 
produzidas, reproduzidas e revisadas por meio de diálogos. Na medida em que as conversações são construídas por todos aqueles participantes, e que os enunciados de cada um são continuamente reavaliados por todos, os eventos comunicativos tendem a propiciar que a cultura emirja da própria interação comunicativa. Nesse sentido, "a linguagem tem uma qualidade emergente, produzida pelos falantes e distanciada deles. A ideia de 'emergência' é central para compreender como a cultura e a linguagem adquirem regularidades por meio da interação de indivíduos sem ser reduzida a eles" (Manheim G Tedlock, 1995: 9).

A noção de emergência dialógica da cultura encerra tanto a ideia de que, por meio da interação, surge algo diferente daquilo que foi enunciado anteriormente quanto a noção de que os eventos comunicativos sempre estão sujeitos a certas contingências. Nesse caso, o mundo sociocultural está constantemente sendo feito e refeito por meio dos discursos proferidos por agentes engajados em atividades comunicativas. Os participantes de um evento comunicativo estão socialmente situados num mundo social dialógico e em processo (Manheim G Tedlock, 1995).

Se assim for, então, a própria noção de medicina tradicional indígena, ao ser posta em diálogo nos múltiplos eventos que ocorrem no campo da saúde indígena, também encerra uma qualidade emergente, tanto no âmbito das políticas da tradição quanto nas múltiplas definições que os povos indígenas lhe atribuem: quando se fala sobre medicina tradicional indígena, tais definições são revistas, e novos sentidos passam a informar essa noção em permanente processo de criação.

Em síntese podemos pontuar algumas ideias centrais que informam o conceito de discurso: 1) 'O discurso é orientado', não só porque é concebido em função do 'objetivo' do locutor, mas também porque ele se desenvolve no tempo, em função de um fim, pretendendo-se chegar a algum lugar; 2) 'O discurso é uma forma de ação', na medida em que toda enunciação é um ato de fala; 3) 'O discurso é interativo', já que toda enunciação, mesmo produzida sem a presença concreta de um destinatário, é, de fato, assumida em uma interatividade constitutiva que pressupõe a troca explícita ou implícita com outros locutores, virtuais ou reais; 4) 'O discurso é contextualizado', pois não se pode atribuir um sentido a um enunciado fora do seu contexto, além de o discurso fazer parte da definição do contexto em que está inscrito; 5) 'O discurso é regido por normas sociais', isto é, nenhum ato de enunciação pode ocorrer sem justificar, de uma maneira ou de outra, seu direito de se apresentar como tal; 6) 'O discurso é assumido em um interdiscurso', já que não adquire sentido, a menos que esteja no interior de um universo de outros discursos. Para interpretar o menor enunciado, é preciso colocá-lo em relação com outros enunciados (Charaudeau G Maingueneau, 2006: 168-172).

Por fim, cabe mencionar a diferença existente entre o discurso falado e o discurso escrito. Ao passo que o discurso falado, por sua própria natureza, é evanescente, e sua duração é limitada às circunstâncias de sua produção, os textos escritos assumem uma duração que permanece através do tempo e do espaço. 
O texto escapa 'do horizonte finito vivido por seu autor' e 'o que o texto diz agora importa mais do que o autor pretendia dizer'. O autor de um texto é capaz de dirigi-lo a uma audiência específica, e de expressar certos significados por meio dele. Porém, em princípio, o texto pode alcançar audiências bastante distantes de seu ator, e pode ser lido de um modo que ele nunca poderia imaginar. Os textos também se separam das amarras que a 'referência ostensiva' proporciona em um discurso falado. A comunicação do significado em uma ação definida depende basicamente da consciência compartilhada entre os elementos do contexto dessa ação. (...) Entretanto, um texto abre novas possibilidades de referência, negadas em comunicações orais, quando ele não está mais saturado por referências ostensivas. Já que eles não dependem, para a sua interpretação, das situações nas quais foram produzidos, os textos abrem novos horizontes ou 'projetam novos caminhos de

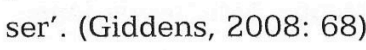

Nessa concepção de Giddens, encontra-se uma diferença fundamental entre os discursos oficiais e os enunciados indígenas, ambos objetos da análise antropológica aqui empreendida: ao passo que os primeiros são veiculados por meio de textos escritos, os segundos se configuram como atos de fala pautados na oralidade constitutiva dos processos comunicativos indígenas. Na medida em que é a escrita que possibilita ao Estado-nação e a organismos internacionais ampliarem o monitoramento reflexivo sobre o mundo da vida das populações adstritas ao seu território, torna-se relevante, justamente, analisar discursos das políticas da tradição, difundidos por meio dos textos oficiais produzidos por essas instituições modernas. O que será feito no próximo capítulo. 
1 As organizações internacionais surgem no início no século XX, com a criação da Liga das Nações em 1918 (Encontro de Versalhes), e têm rápida ascensão a partir da $1^{\text {a }}$ Guerra Mundial (Giddens, 2008).

2 O armazenamento eletrônico das informações - fitas, CDs, DVDs etc. - é um dos principais fenômenos relativos aos Estados modernos, já que expandem a variedade dos modos de registro e de armazenamento disponíveis (Giddens, 2008: 39).

3 Giddens (1991) reconhece dois mecanismos de desencaixe que contribuem na formação das organizações modernas: as fichas simbólicas, por exemplo, o dinheiro; e os sistemas peritos, que se constituem em sistemas de excelência técnica e competência profissional.

4 Canclini (2003: 18) distingue em termos epistemológicos e políticos o conceito de hibridação empregado pelas ciências sociais daquele que é usado em biologia: "No tocante a sua contribuição ao pensamento político (...), a hibridação não é sinônimo de fusão sem contradição, mas, sim, pode ajudar a dar conta de formas particulares de conflito geradas na interculturalidade".

5 Greene (1998) estabelece uma diferença entre recursos biomédicos - serviços, produtos, biotecnologias; medicina biomédica, científico-ocidental, sustentada sobre o paradigma biológico - e poder biomédico - influência política internacional biomedicamente orientada (política de saúde, organização e pesquisa).

6 Menéndez (2003) entende por modelo de atenção todas as atividades dos grupos sociais relacionadas à atenção aos padecimentos em termos intencionais, isto é, que buscam prevenir, tratar, controlar, aliviar e/ou curar um padecimento determinado. 


\section{Os Discursos Oficiais e a Emergência do Tradicional como Objeto de Políticas Públicas}

As relações mantidas entre o Estado brasileiro e os organismos internacionais exercem grande influência no processo de elaboração das políticas públicas nacionais. Portanto, neste capítulo apresento um mapeamento dos discursos oficiais dos organismos internacionais e das políticas brasileiras que qualificam os seus objetos segundo o conceito de 'tradição' - medicina tradicional, conhecimentos tradicionais, povos e comunidades tradicionais, parteiras tradicionais. Como os enunciados sobre a medicina tradicional indígena também fazem parte desse contexto comunicativo oficial, torna-se fundamental considerá-lo para entender os sentidos agregados a essa categoria, uma vez que passa a integrar a formação discursiva das políticas da tradição.

Afim de que se compreenda a maneira como essas relações propiciam o surgimento das políticas da tradição e de que forma, ao qualificar os objetos das políticas públicas, o tradicional abre caminho para a emergência de objetos híbridos de políticas públicas, analiso os discursos oficiais dos organismos internacionais e das políticas públicas brasileiras à luz da reflexão teórica efetuada no capítulo anterior. As diretrizes internacionais que mais exercem influência no forjamento das políticas nacionais voltadas para o desenvolvimento das medicinas tradicionais indígenas são as recomendadas pela Organização Mundial da Saúde (OMS), pela Organização Internacional do Trabalho (OIT) e pela Organização das Nações Unidas (ONU).

\section{A medicina tradicional no âmbito dos discursos internacionais}

Ao analisar os documentos elaborados pela OMS, pela OIT e pela ONU, bem como pelas políticas nacionais de práticas integrativas e complementares de plantas medicinais e fitoterápicos, de saúde indígena, de sustentabilidade dos povos e comunidades tradicionais e de proteção aos conhecimentos tradicionais associados, percebem-se entre eles inúmeros alinhamentos discursivos. Os organismos inter- 
nacionais apresentam recomendações a serem seguidas pelos governos nacionais, e as políticas públicas buscam contemplá-las em seu escopo. É necessário, portanto, refletir sobre a forma como as recomendações dos organismos internacionais influenciam o Estado brasileiro na elaboração dessas políticas.

\section{O discurso da Organização Mundial da Saúde}

Desde a década de 1970, a OMS recomenda que, para melhorar as condições de saúde da população, as medicinais tradicionais e os seus praticantes sejam considerados pelos Estados nacionais na organização da atenção básica à saúde. Em 1978, a Declaração de Alma-Ata, ${ }^{1}$ "em consonância com a nova ordem econômica internacional", reconhece que os praticantes das medicinas tradicionais poderiam colaborar nos cuidados primários de saúde, desde que devidamente treinados para trabalhar e responder às necessidades das comunidades.

É somente em 2002 que a OMS publica o documento Estratégias da OMS sobre a Medicina Tradicional 2002-2005 com as diretrizes para a integração da medicina tradicional (MT) aos sistemas nacionais de saúde. Nesse documento, apesar de reconhecer a grande diversidade das orientações teóricas que fundamentam as práticas da MT, a OMS emprega a categoria no singular e propõe uma definição prática e útil, ampla e inclusiva para o termo. Por medicina tradicional se entende um conjunto de

\footnotetext{
Práticas, enfoques, conhecimentos e crenças sanitárias diversas que incorporam medicinas baseadas em plantas, animais e/ou minerais, terapias espirituais, técnicas manuais e exercícios aplicados de forma individual ou em combinação para manter o bem-estar, além de tratar, diagnosticar e prevenir as enfermidades. (OMS, 2002: 7)
}

Por apresentar baixo custo, ser acessível e atender a algumas necessidades de saúde da população, a MT pode contribuir para a redução das taxas de morbimortalidade, principalmente em países pobres. A fim de explorar o potencial que tais medicinas encerram, os Estados precisariam criar medidas para regulamentar e ampliar o acesso às suas terapêuticas. Dessa forma, a OMS apresenta estratégias para que os governos possam controlar o exercício das medicinas tradicionais, prevendo meios de garantir a segurança, a eficácia, a qualidade, o acesso e o uso racional dos seus conhecimentos, práticas e praticantes. Essas políticas deverão incluir temas como a legislação e a regulação de produtos e práticas; a formação e a licença para os praticantes; a pesquisa e o desenvolvimento; e a distribuição dos recursos econômicos.

No entanto, há vários desafios a serem enfrentados para validar as medicinas tradicionais e integrá-las aos sistemas sanitários nacionais. Dentre 
eles, estão a falta de evidências clínicas sobre a eficácia de suas terapêuticas e as consequentes dificuldades em assegurar a qualidade, a segurança e o uso correto desses recursos. Por terem se desenvolvido em diferentes contextos culturais, estando fundamentadas em cosmologias e filosofias distintas, a MT não é homogênea, o que dificultaria a identificação das terapias mais seguras e eficazes do ponto de vista da medicina científica. Na visão da OMS, a diversidade cultural das medicinas tradicionais faz com que médicos alopatas não as reconheçam como recursos terapêuticos válidos, tornando difícil a sua integração aos sistemas de saúde oficiais.

A medicina alopática tem sua base firmemente arraigada na cultura ocidental. Os médicos enfatizam, portanto, seu enfoque científico, e afirmam que ela está tanto livre de valor quanto não está marcada pela cultura. As terapias de MT/ MCA se desenvolveram de formas distintas, sendo muito influenciadas pelas condições culturais e históricas dentro das quais evoluíram. Suas bases comuns são um enfoque holístico da vida, o equilíbrio entre a mente, o corpo e seu entorno, e a ênfase na saúde em vez da enfermidade. No geral, o praticante se centra na condição do paciente individual, em lugar de colocá-la na doença ou na enfermidade particular que está sofrendo. (OMS, 2002: 23, tradução minha)

A insuficiência de ensaios clínicos e a ausência de controle das agências sanitárias oficiais devem ser solucionadas por meio de pesquisas científicas sobre as MTs. À ciência cabe o papel de identificar as terapias seguras e depurá-las dos aspectos culturais, das crenças e dos valores que comprometem a sua eficácia. Portanto, para ser integrada aos sistemas de saúde nacionais, a MT precisa ser validada cientificamente, para, em seguida, ser reconhecida e difundida como fonte universal, legítima e regulada de cuidados em saúde. Enquanto isso não ocorre, permanece como potencial a ser desenvolvido pelos métodos científicos de validação.

A OMS (2002: 28) identifica a cooperação entre praticantes das MTs e médicos alopatas como uma estratégia para estimular o uso racional dos produtos e terapêuticas tradicionais. Principalmente em áreas com escasso acesso aos serviços de saúde, a atuação conjunta e complementar entre profissionais da saúde e praticantes tradicionais "pode facilitar a disseminação eficaz de mensagens sanitárias importantes entre as comunidades, além de fomentar a prática segura da MT".

Para regulamentar a atuação dos praticantes das MTs, a agência das Nações Unidas sugere a criação de mecanismos de qualificação e licenciamento de modo a permitir que somente pessoas habilitadas possam praticar ou vender os seus produtos. A qualificação dos praticantes deverá ser realizada via programas de formação que incluam elementos básicos de atenção primária e saúde pública. Um dos campos em que essa recomendação se aplica é o da saúde materno-infantil, já 
que a colaboração de parteiras tradicionais devidamente treinadas na assistência à gestação e ao parto pode beneficiar tanto a saúde da puérpera quanto do recémnascido (OMS, 1985).

\section{A OIT 169 e a Declaração da ONU sobre os Direitos dos Povos Indígenas}

A Convenção n. 169 sobre Povos Indígenas e Tribais em Países Independentes da Organização Internacional do Trabalho (OIT), publicada em julho de 1989 e ratificada pelo Brasil em 2002, apresenta uma série de recomendações aos Estados que tratam, principalmente, da questão da terra/território e também dos princípios fundamentais do trabalho. No entendimento da OIT, os povos indígenas e tribais - entendidos como "segmentos nacionais com identidade e organização próprias, cosmovisões específicas e especial relação com a terra que habitam" (OIT, 1989: 12), distintos de outros segmentos da população nacional - contribuem "para a diversidade cultural, a harmonia social e ecológica da humanidade e para a cooperação internacional" (OIT, 1989: 19), bem como para a formação das sociedades nacionais e de suas respectivas identidades socioculturais.

No artigo $2^{\circ}$ da convenção, a OIT (1989: 23) recomenda aos Estados criarem medidas de proteção e promoção aos "direitos sociais, econômicos e culturais desses povos, respeitando sua identidade social e cultural, costumes e tradições e suas instituições". É nesse contexto em que estão situados os direitos de acesso aos serviços de saúde, prioritariamente aos da atenção primária, do exercício das medicinas tradicionais indígenas e o consequente reconhecimento oficial dos métodos de prevenção, das práticas curativas e dos medicamentos indígenas.

A mesma perspectiva colaboracionista encontrada no texto da OMS (2002) sobre as medicinas tradicionais é adotada pela Convenção n. 169 da OIT. Ao instar os governos a atuarem em cooperação com os povos indígenas para implantarem no âmbito dos Estados nacionais as recomendações feitas em seu texto, a convenção instituía consulta aos povos indígenas e a participação destes em todos os níveis de tomada de decisões (públicas e privadas) governamentais que afetem as suas vidas. Além disso, estabelece que cabe a eles decidirem sobre as suas próprias prioridades de desenvolvimento (OIT, 1989).

Da mesma forma que na OIT 169, na Declaração das Nações Unidas sobre o Direito dos Povos Indígenas, de 13 de setembro de 2007, encontra-se a assertiva sobre contribuição desses povos para a diversidade cultural planetária, considerada "patrimônio comum da humanidade" (ONU, 2007: 2). Nesse documento, a ONU, aderindo à perspectiva colaboracionista, fomenta a ideia de que os Estados nacionais estabeleçam relações de cooperação com os povos indígenas para a execução de ações governamentais de proteção e promoção aos direitos indígenas. Às Nações 
Unidas cabe fazer valer esses direitos, na medida em que esses são assuntos de preocupação, interesse e responsabilidade internacionais.

Nessa declaração, a ONU (2007: 14) reconhece os direitos coletivos como indispensáveis para a "existência, bem-estar e desenvolvimento integral" dos povos indígenas, a livre autodeterminação e a autonomia para lidar com as questões internas e locais, e propõe ações de "revitalização das tradições" e dos "costumes culturais", bem como de manutenção das práticas e dos processos indígenas de transmissão dos conhecimentos. Também prevê o direito dos povos indígenas ao acesso aos serviços de saúde e ao exercício das suas medicinais tradicionais, incluindo "a conservação de suas plantas, animais e minerais de interesse vital desde o ponto de vista médico" (ONU, 2007: 6).

\section{Alinhamentos e descompassos entre os discursos OIT, ONU e OMS}

Nos consensos internacionais analisados, pode-se distinguir as recomendações apresentadas na Convenção n.169 da OIT e na Declaração dos Direitos dos Povos Indígenas da ONU daquelas expostas no documento Estratégias para a Medicina Tradicional 2002-2005, redigido pela OMS (2002). A primeira diferença que se pode destacar diz respeito à abrangência dos documentos: tanto a Convenção da OIT quanto a Declaração das Nações Unidas estimulam os Estados a protegerem e promoverem os direitos dos povos indígenas. Já o documento da OMS tem como objeto a integração da medicina tradicional aos sistemas sanitários nacionais e, nesse caso, a medicina tradicional indígena, apesar de ter sua importância, constitui apenas mais um dos sistemas terapêuticos contemplados. Ao passo que na OIT e na ONU defende-se o direito dos povos indígenas à saúde e à manutenção das suas medicinas tradicionais e práticas de saúde, na OMS elabora-se uma estratégia para o desenvolvimento e a regulamentação das medicinas tradicionais.

Constitui igualmente um contraste o fato de a OIT e a ONU reconhecerem a contribuição dos povos indígenas para incrementar a diversidade e a riqueza das civilizações e das culturas, ao passo que para a OMS o fato de a MT estar envolta em crenças e valores culturais figura um obstáculo para a sua integração aos sistemas oficiais de saúde. A diversidade cultural, nesse sentido, apresenta-se como um empecilho à validação das medicinas tradicionais no âmbito desses sistemas.

Esses documentos apresentam em comum a perspectiva colaboracionista, que está a serviço do desenvolvimento político e econômico mundial, e a relação entre organismos internacionais e Estados nacionais: ao passo que a OIT 169 e a Declaração das Nações Unidas incentivam os governos a estabelecerem relações de cooperação com os povos indígenas na implementação de políticas e programas, a OMS recomenda a colaboração dos praticantes da MT na organização dos serviços 
de atenção primária à saúde. É por isso que, na Declaração da Alma-Ata, entendese a colaboração como a postura acordada à nova ordem internacional.

Ao reconhecer os Estados como instâncias político-administrativas legítimas, aptas a implementar os programas de valorização e regulamentação do tradicional, os organismos internacionais contribuem para o fortalecimento das soberanias nacionais e para a elaboração de políticas públicas estatais. Como, então, as recomendações das agências da ONU influenciam a conformação das políticas da tradição brasileiras?

\section{A medicina tradicional nos discursos oficiais brasileiros}

No Brasil, as orientações dos organismos internacionais são efetivadas por meio de políticas públicas, sustentadas em diferentes suportes legais, que abrangem ações e programas governamentais instituídos para o alcance de objetivos e metas específicos.

Políticas públicas configuram decisões de caráter geral que apontam rumos e linhas estratégicas de atuação governamental, reduzindo os efeitos da descontinuidade administrativa e potencializando os recursos disponíveis ao tornarem públicas, expressas e acessíveis à população e aos formadores de opinião as intenções do governo no planejamento de programas, projetos e atividades. (Brasil, 2006b: 9)

Dentre as políticas de saúde influenciadas pelas recomendações internacionais, encontram-se a Política Nacional de Atenção a Saúde dos Povos Indígenas (PNASPI), a Política Nacional de Práticas Integrativas e Complementares (PNPIC) e a Política Nacional de Plantas Medicinais e Fitoterápicos (PNPMF). Com os projetos de lei, alinhados às diretrizes internacionais e em trâmite na Câmara dos Deputados Federais, pretende-se regulamentar as medicinas tradicionais e o ofício de um dos seus praticantes - as parteiras indígenas. Ainda compõem a formação discursiva das políticas da tradição a Política Nacional de Desenvolvimento Sustentável dos Povos e Comunidades Tradicionais (PNPCT) e a Medida Provisória (MP) n. 2.18616 (Brasil, 2001), que discorre sobre o acesso ao patrimônio genético brasileiro.

\section{Saúde indígena e o direito à atenção diferenciada}

Ao reconhecer o direito dos povos indígenas à sua organização social, costumes, línguas, crenças e tradições, bem como os direitos originários sobre as terras que tradicionalmente ocupam, a Constituição Federal de 1988 instaurou as bases para o desenvolvimento de diferenciadas políticas públicas direcionadas a 
esse segmento populacional. ${ }^{2}$ No entanto, foi somente em 1999, com a criação do subsistema de Atenção a Saúde Indígena e da Política Nacional de Atenção a Saúde dos Povos Indígenas (PNASPI), que uma política específica de atenção à saúde indígena foi instituída. ${ }^{3}$ Como afirma Langdon (2004: 34), a PNASPI é o "resultado do cruzamento de fatores históricos e políticos postos em movimento desde a década de 1980". Além da Constituição Federal e da promulgação dos direitos indígenas internacionais, as emergências do movimento indígena e do movimento da reforma sanitária, que culminou com a criação do Sistema Único de Saúde (SUS), também contribuíram para a reordenação dos serviços de saúde prestados aos povos indígenas.

Com a PNASPI (Brasil, 2002), aprovada por meio da Portaria n. 254/MS de 2002, busca-se compatibilizar a Lei Orgânica da Saúde - Lei n. 8.080/1990 (Brasil, 1990) - com a Constituição Federal. Essa política reconhece as especificidades étnicas e culturais e os direitos territoriais dos povos indígenas, estabelecendo como seu propósito garantir-lhes o acesso à atenção integral à saúde. Além de buscar contribuir para a superação dos fatores que tornam os povos indígenas vulneráveis aos agravos de maior magnitude, ela também reafirma a eficácia da medicina tradicional indígena e o direito desses povos à sua cultura. Portanto, se a política de saúde indígena é orientada pelos mesmos princípios doutrinários que regem o SUS - universalidade, equidade e integralidade -, o que lhe confere especificidade é o princípio da atenção diferenciada.

Visando a prestar um atendimento diferenciado à saúde indígena no Brasil, essa política estabelece o Distrito Sanitário Especial Indígena (DSEI) como modelo de organização de serviços de atenção primária à saúde. Além de propor um modelo complementar e diferenciado de organização dos serviços adequado às realidades e contextos socioculturais indígenas, essa política também reconhece o direito desses povos ao acesso a uma atenção diferenciada à saúde que contemple as suas especificidades culturais, epidemiológicas e operacionais. Assim, no texto da PNASPI (Brasil, 2002) verifica-se que o conjunto de diretrizes deve respeitar as concepções, os valores e as práticas relativas ao processo saúde-doença próprios a cada sociedade indígena e a seus diversos especialistas.

Apesar de não se explicitarem na PNASPI os sentidos que informam a noção de atenção diferenciada com a qual se está operando, eles aparecem no texto oficial, particularmente, ao recomendar que os serviços atuem de forma articulada aos sistemas tradicionais indígenas de saúde - as medicinas tradicionais indígenas. No texto oficial da política, tais sistemas são determinados a operar com base em uma concepção holística de saúde, pautada no estabelecimento de relações sociocósmicas harmoniosas.

As práticas de cura respondem à lógica interna de cada comunidade e são produto de sua relação particular com o mundo espiritual e os seres do ambiente em que vivem. Essas práticas e concepções são, geralmente, recursos de saúde de eficácia 
empírica e simbólica, de acordo com a definição mais recente da Organização Mundial da Saúde. (Brasil, 2002: 16-17)

Apesar de se basear na definição da OMS sobre as medicinas tradicionais para conceituar os sistemas indígenas tradicionais de saúde, a PNASPI não adere inteiramente à perspectiva integracionista, adotando como estratégia para melhorar a situação de saúde da população indígena a articulação entre as medicinas indígenas e os serviços oficiais de saúde. Todavia, a política não deixa claro como implementar a diretriz da articulação de sistemas nas rotinas tradicionais da atenção à saúde. Desse modo, a política deixa margem para que essa diretriz seja apreendida pelos agentes que atuam no campo da saúde indígena pelo viés ideológico da integração - dispositivo tutelar historicamente empregado pelo Estado na relação com os povos indígenas.

Entre os antropólogos da saúde indígena, impera a visão de que o conceito de atenção diferenciada ainda precisa ser operacionalizado nas diferentes instâncias do SUS e do próprio subsistema (Garnelo, 2004; Langdon, 2004). "Apesar de esse princípio ser parte da PNASPI, não se conseguiu desenvolver diretivas que orientem efetivamente as equipes de saúde. Esforços para oferecer atenção diferenciada são isolados e há uma tendência à 'essencialização' das noções de cultura e tradição" (Langdon, 2007: 9).

Na concepção de Langdon (2007: 9), "a atenção diferenciada supõe que profissionais da saúde devem considerar a particularidade cultural da comunidade indígena e respeitar as práticas de saúde tradicionais". Para tanto, os profissionais da saúde precisariam estar habilitados para reconhecer, refletir e dialogar com os modos de vida das comunidades onde atuam, e considerar "as diversas formas de autoatenção praticadas na área de abrangência de seus serviços" (Langdon, 2004: 44). No entanto, apesar de a política prever a necessidade de recursos humanos com competência intercultural para atuar na saúde indígena, o subsistema ainda apresenta limitações no que se refere tanto à quantidade quanto à qualidade da atenção propriamente dita.

Em termos de qualidade dos serviços prestados, os DSEIs vêm se mostrando pouco (...) sensíveis às formas próprias de cosmovisão e de organização política das etnias atendidas. (...) Os documentos normativos do subsistema de saúde indígena são pródigos na repetição de princípios genéricos de ação (como preconizar a articulação e fortalecimento da medicina tradicional) que não se traduzem em atividades concretas nem nas programações anuais de atividades dos DSEIs, nem nas práticas sanitárias das equipes. (Garnelo, 2004b: 13)

O que atualmente se observa nas práticas dos serviços de saúde indígena é justamente o contrário da articulação de sistemas tal como preconizada nessa política. Geralmente, entre gestores e profissionais da saúde indígena, prepondera 
uma perspectiva tecnicista que desconsidera a dimensão comunicativa do fazer saúde e opera com uma visão estereotipada sobre as medicinas tradicionais indígenas. A percepção de que as culturas indígenas constituem um obstáculo ao fazer da saúde nos contextos comunitários ainda é vigente no campo da saúde indígena e, diante disso, apesar da PNASPI reconhecer a eficácia das medicinas indígenas e preconizar o respeito aos saberes tradicionais, o paradigma biomédico ainda é considerado o único válido, verdadeiro e universal (Langdon, 2004).

\section{Práticas integrativas e complementares e as plantas medicinais e fitoterápicas}

Outras políticas públicas de saúde foram influenciadas pelas recomendações da OMS e dialogam com as medicinas tradicionais, mais particularmente com os conhecimentos e as práticas indígenas: a PNPIC e PNPMF.

O Ministério da Saúde (MS), como forma de garantir a integralidade da atenção no âmbito do SUS, em 3 de maio de 2006, publicou a Portaria n. 971, que aprova a PNPIC. Essa política se apresenta como uma estratégia de ampliação das opções terapêuticas aos usuários do SUS para incrementar "o acesso a serviços antes restritos a prática de cunho privado" (Brasil, 2006c: 5) e integrar e institucionalizar no SUS as práticas integrativas e complementares, garantindo a qualidade, a eficácia, a segurança e a racionalização das ações de saúde.

A PNPIC se encontra alinhada às recomendações da OMS (2002) no que se refere à inserção da MT aos sistemas oficiais de saúde. Para o MS, a noção de práticas integrativas e complementares é equivalente ao conceito de medicina tradicional como postulado pelo organismo internacional. Em seu escopo, a MT abarca práticas da medicina tradicional chinesa (acupuntura), da homeopatia, da fitoterapia, da medicina antroposófica e do termalismo social/crenoterapia (uso terapêutico das fontes naturais de águas minerais). Como pertencentes a sistemas médicos complexos que apresentam "uma visão ampliada do processo de saúdedoença e da promoção global do cuidado humano, especialmente do autocuidado", a inserção desses recursos terapêuticos complementares no SUS contribuiriam para a efetivação do princípio de integralidade (Brasil, 2006c: 10). No entanto, não são integrados os sistemas médicos complexos ao SUS, mas apenas algumas das suas práticas - aquelas validadas pela ciência ocidental moderna.

A PNPIC também demonstra a necessidade de estar articulada à PNASPI, mas não há uma proposta concreta para isso. O tema das plantas medicinais e da fitoterapia - uso de plantas medicinais em suas diferentes formas farmacêuticas, sem a utilização de substâncias ativas isoladas, mesmo as de origem vegetal (Brasil, 2006c: 10) -, abordado nessa política, apresenta uma interface mais direta com as medicinas tradicionais indígenas. Entretanto, apesar de mencionado, o uso das 
plantas e dos remédios caseiros é desenvolvido de forma mais sistemática pela PNPMF.

A PNPMF, aprovada pelo decreto n. 5.813, de 22 de junho de 2006 (Brasil, 2006b), está em consonância com a PNPIC ao incrementar a oferta de opções terapêuticas aos usuários do SUS, ampliando o acesso às plantas medicinais, fitoterápicos e serviços relacionados à fitoterapia. Além disso, com essa política, objetiva-se garantir "à população brasileira o acesso seguro e o uso racional de plantas medicinais e fitoterápicos, promovendo o uso sustentável da biodiversidade, o desenvolvimento da cadeia produtiva e da indústria (farmacêutica) nacional" (Brasil, 2006b: 20).

A PNPMF (Brasil, 2006b: 11) também adere ao conceito de medicina tradicional e às recomendações da OMS para "promover a integração entre a prática da medicina tradicional e da assistência sanitária moderna" e está, portanto, alinhada à diretriz que prevê $\mathrm{a}$

Formulação de políticas e regulamentações nacionais referentes à utilização de remédios tradicionais de eficácia comprovada e exploração das possibilidades de se incorporar os detentores de conhecimento tradicional às atividades de atenção primária em saúde, fornecendo-lhes treinamento correspondente. (OMS apud Brasil, 2006b: 11)

A cooperação entre praticantes tradicionais e a assistência sanitária constitui uma das medidas estratégicas a serem adotadas pela PNPMF para transformar as plantas e os remédios caseiros utilizados no âmbito das MTs em medicamentos fitoterápicos. Nesse contexto, a biodiversidade e a diversidade cultural, que abarcam a multiplicidade de conhecimentos tradicionais sobre as propriedades terapêuticas das plantas medicinais, encerram um potencial a ser explorado.

\footnotetext{
Além de seu uso como substrato para a fabricação de medicamentos, as plantas são também utilizadas em práticas populares e tradicionais como remédios caseiros e comunitários, processo conhecido como medicina tradicional. Além desse acervo genético, o Brasil é detentor da rica diversidade cultural que resultou em um acúmulo considerável de conhecimentos e tecnologias tradicionais, passados de geração a geração, entre os quais se destaca o vasto acervo de conhecimentos sobre manejo e uso de plantas medicinais. (Brasil, 2006b: 14)

Porém, para reconhecer e promover o uso de plantas medicinais e dos remédios caseiros, na PNPMF também se estabelece a necessidade dos conhecimentos e práticas terapêuticas tradicionais serem submetidos ao processo de validação científica. A qualidade, eficácia e segurança dos fitoterápicos deverão ser garantidas mediante ao emprego de modernas técnicas de fabricação. Assim, a ciência continua com o poder de registrar, sistematizar e uniformizar tais saberes, de modo a permitir a sua regulamentação, difusão e universalização.
} 
Com a PNPMF, pretende-se incentivar a produção dos fitoterápicos em escala industrial, já que esses produtos são objeto de interesse das empresas privadas que compõem o Complexo Produtivo da Saúde. Com essa prática, o Estado não só reduziria os gastos públicos com a aquisição de medicamentos, mas promoveria a descoberta de substâncias potencialmente utilizadas em processos de "inovação em saúde" e na fabricação de "modernas drogas terapêuticas" (Brasil, 2006a: 12). Segundo essa política, o Brasil apresenta todas as condições necessárias para elaborar um modelo de desenvolvimento nacional soberano para a área da saúde (Brasil, 2006b: 14).

\section{A medicina tradicional no discurso de deputados federais}

Outra modalidade de documentos integrante do conjunto de discursos que tratam das medicinas tradicionais são os projetos de lei (PLs) que atualmente tramitam na Câmara Legislativa de Deputados Federais do Brasil: o PL n. 5.078/2005 (Brasil, 2005a), proposto por Eduardo Valverde; e o PL n. 2.145/2007 (Brasil, 2007b), da deputada Janete Capibaribe. Esses textos também dizem respeito às intenções do Estado de regulamentar os conhecimentos, as práticas e os praticantes tradicionais, transformando-os em objetos de políticas públicas.

O PL do deputado Eduardo Valverde também está alinhado com as recomendações da $\mathrm{OMS}^{4}$ ao prever a regulamentação dos "mecanismos para a proteção, promoção, reconhecimento e exercício da medicina tradicional, das terapias complementares e do patrimônio biogenético das populações indígenas". De acordo com esse PL, a normatização e a regulação da MT possibilitarão sua integração ao SUS, "seja como coadjuvante aos tratamentos da medicina alopática, seja como fonte exclusiva de tratamento, podendo, inclusive, baratear os custos dos mesmos" (Brasil, 2005a). A integração da MT ao SUS deverá ser realizada ainda por meio da validação científica das técnicas, métodos e procedimentos das MTs. Entretanto, isso tudo dever ser feito "sem afetar a cultura e os costumes dos povos indígenas", de acordo com o PL n. 5.078/2005 (Brasil, 2005a).

Os povos indígenas ganham destaque, na medida em que o projeto de lei define as medicinas tradicionais como a "soma de todos os conhecimentos, aptidões e práticas baseados nas teorias, crenças e experiências tradicionais dos diferentes povos indígenas que se utilizam para manter a saúde e prevenir, diagnosticar ou tratar as doenças físicas e mentais". O conhecimento tradicional, por sua vez, é pensado como o "conjunto de usos e costumes por meio dos quais os povos indígenas e comunidades étnicas constroem (...) os conhecimentos coletivos próprios de cada cultura" (Brasil, 2005a).

Já o PL n. 2.145/2007 (Brasil, 2007b), proposto pela deputada Janete Capibaribe, visa a regulamentar o exercício de um dos praticantes das medicinas 
tradicionais - as parteiras tradicionais. ${ }^{5}$ Nesse PL, defende-se que a proposta de regulamentação da atuação das parteiras tradicionais se justifica tanto por esse ofício ser "tão antigo quanto a própria humanidade" quanto pelo fato de que essas praticantes atuam em regiões do país onde o acesso aos serviços de saúde é precário, além de haver carência de profissionais da saúde para realizarem os procedimentos do pré-natal e de assistência ao parto. ${ }^{6}$ Diante dessa informação, nota-se que a atuação das parteiras tradicionais tem contribuído para a redução dos índices de morbimortalidade materno-infantil no Brasil, na medida em que salvam as vidas das parturientes e dos recém-nascidos.

Portanto, regulamentar a atividade de parteira tradicional constitui uma forma de reconhecê-la oficialmente como profissionais que prestam um atendimento 'humanizado'. A missão desse PL seria "resgatar as parteiras tradicionais da clandestinidade em que exercem a profissão e inseri-las no SUS, como estratégia para oferecer um atendimento humanizado às gestantes mais carentes" (Brasil, 2007b).

Dentre as atividades desempenhadas pelas parteiras tradicionais, ao terem o seu oficio regulamentado e a sua profissão reconhecida, estão: prestar assistência à gestante durante o pré-natal e no 'parto natural' realizado em domicílios, casas de parto e maternidades públicas; cuidar das parturientes, puérperas e recémnascidos; e encaminhar a gestante para avaliação médica quando for identificado risco para a gestação ou o parto. O SUS, a partir da regulamentação, remunerará as parteiras com um salário mínimo, pelos serviços prestados, além de fornecer os equipamentos e os materiais de consumo necessários à sua adequada atuação.

Para prestar os serviços descritos, a parteira terá de participar de um curso de capacitação, que objetiva a segurança da atividade. As parteiras passam a ter, assim, o exercício de sua atividade condicionado "à conclusão do curso de qualificação ministrado pelo MS ou por secretarias de saúde dos estados federados" (Brasil, 2007b) e, como integrantes das equipes de saúde do SUS, sua atuação supervisionada por médicos ou enfermeiros.

\section{Sustentabilidade e conhecimento tradicional associado}

Abordam-se também a Política Nacional de Desenvolvimento dos Povos e Comunidades Tradicionais (PNPCT) e a MP n. 2.186-16/2001 (Brasil, 2001), que dispõe sobre o acesso ao patrimônio genético da União, uma vez que utilizam o tradicional para qualificar o seu público-alvo e o seu objeto.

A PNPCT, instituída por meio do Decreto n. 6.040, de 7 de fevereiro de 20077 (Brasil, 2007c), está sob a responsabilidade do Ministério do Desenvolvimento Social (MDS). Com essa política, que almeja se tornar um canal de inclusão social dos povos e comunidades tradicionais, reconhecendo a diversidade cultural 
como característica da identidade brasileira, pretende-se promover a cidadania plena desses segmentos populacionais. Por povos e comunidades tradicionais são entendidos aqui os

Grupos culturalmente diferenciados e que se reconhecem como tais, que possuem formas próprias de organização social, que ocupam e usam territórios e recursos naturais como condição para sua reprodução cultural, social, religiosa, ancestral e econômica, utilizando conhecimentos, inovações e práticas gerados e transmitidos pela tradição. (Brasil, 2007a)

Essa definição contempla povos indígenas, quilombos, comunidades locais, extrativistas (seringueiros), comunidades de terreiros (candomblé), ciganos, comunidades de faxinais, pescadores, quebradeiras de coco, entre outros.

A PNPCT (Brasil, 2007a) tem como objetivo geral a promoção do "desenvolvimento sustentável dos povos e comunidades tradicionais, com ênfase no reconhecimento, fortalecimento e garantia dos seus direitos territoriais, sociais, ambientais, econômicos e culturais, com respeito à valorização da sua identidade, suas formas de organização e suas instituições". Dentre os objetivos específicos a serem destacados estão os relacionados ao acesso aos serviços de saúde culturalmente adequados com ênfase nas concepções e práticas da medicina tradicional; e ao reconhecimento, proteção e promoção dos direitos sobre os conhecimentos e práticas tradicionais.

Por sua vez, a MP n. 2.186-16 (Brasil, 2001), que discorre sobre o acesso ao patrimônio genético de propriedade da União, constitui o dispositivo legal que aborda o conhecimento tradicional, dessa vez, associado à biodiversidade. ${ }^{8} \mathrm{Com}$ essa MP, reconhecem-se os direitos de propriedade intelectual das comunidades indígenas e locais sobre os conhecimentos tradicionais associados à biodiversidade, bem como de decisão sobre o uso que desejam fazer desses conhecimentos, sendo-lhes assegurado o direito à repartição de benefícios quando forem titulares dos conhecimentos acessados.

Dentre as definições adotadas pela MP interessa reter a de comunidades indígenas e locais entendidas aqui como grupos humanos diferenciados "por suas condições culturais, que se organizam, tradicionalmente, por gerações sucessivas e costumes próprios, e que conservam suas instituições sociais e econômicas", bem como a definição de conhecimento tradicional associado, entendido como informação ou prática, individual ou coletiva, de comunidade indígena ou local, com valor real ou potencial, associada ao patrimônio genético. Os conhecimentos tradicionais associados são reconhecidos por essa MP como patrimônio cultural brasileiro, o que os habilita a serem objetos de cadastro. Por sua vez, o acesso ao conhecimento tradicional associado é compreendido como um processo de 
obtenção de informação sobre conhecimento ou prática individual e coletiva, associada ao patrimônio genético, de comunidade indígena ou local, para fins de pesquisa científica, desenvolvimento tecnológico ou bioprospecção, visando à sua aplicação industrial ou de outra natureza. (Brasil, 2001)

\section{A influência da OMS sobre as políticas brasileiras e as implicações do desenvolvimento}

Os organismos internacionais desempenham papel fundamental na consolidação e manutenção da soberania dos Estados nacionais. E, mesmo que não tenham o poder de interferir diretamente nas decisões político-administrativas internas ao Estado, exercem sua influência por meio de recomendações pautadas em consensos estabelecidos entre países-membros dessas organizações. De qualquer forma, não convém menosprezar o poder simbólico que tal influência exerce sobre a formulação das políticas nacionais, principalmente no que se refere ao poder simbólico de fazer existir pela nomeação os objetos dessas políticas públicas.

Os efeitos que as recomendações da OMS têm sobre o processo de construção das políticas de saúde brasileiras são exemplares da forma que esses arranjos assumem. Por um lado, a colaboração da medicina tradicional para a redução dos índices de morbimortalidade das populações dos países em desenvolvimento pode ser entendida como justificativa para se legitimarem conhecimentos e práticas tradicionais de saúde, e tais índices podem ser tomados como razão para se ampliar a cobertura da atenção primária. Por outro, subjacentes à perspectiva colaboracionista estão os interesses no desenvolvimento médico, por meio dos quais se identifica o potencial econômico das medicinas tradicionais a ser explorado, as quais constituem alternativas terapêuticas de baixo custo.

No entanto, o discurso sobre a colaboração exprime a oposição entre as ideias de evolução e de progresso cultural - representada pela ciência, pelos Estados desenvolvidos e pela cultura ocidental - e a estaticidade das culturas tradicionais, típicas das nações subdesenvolvidas e dos grupos subordinados, entre eles, os povos indígenas. Nesse caso, a MT é compreendida como um conjunto de práticas estáticas e passivas, arraigadas a "crendices populares", que se perpetuam desde tempos imemoriais.

Ideias de desenvolvimento sobre a integração das etnomedicinas estão imersas em um pântano de construções ocidentais que apagam a agência social dos praticantes das etnomedicinas - a habilidade para realizar mudanças sociais, culturais, enfim médicas -, via a manutenção da ideologia que define o estático como a contraparte negativa do progresso. Essa ideologia valoriza o desenvolvimento como o único representante do progresso em si mesmo. (Greene, 1998: 647, tradução minha) 
A definição adotada pela OMS, ao mesmo tempo que instrumentaliza o conceito de medicina tradicional, viabiliza a sua criação como objeto de políticas nacionais. As políticas de saúde no Brasil, por exemplo, aderem ao conceito instrumental e às recomendações da OMS ao possibilitarem a incorporação das medicinas tradicionais no âmbito do sistema oficial de saúde brasileiro. No discurso que fundamenta essas políticas, a integração de práticas e praticantes tradicionais pode contribuir para efetivar o princípio da integralidade da atenção preconizado pelo SUS.

Todavia, para incorporar a MT aos sistemas nacionais de saúde, é necessário criar dispositivos para regulamentá-la, de modo que garanta as condições de segurança, qualidade, eficácia e uso racional das suas terapêuticas. Considerando que "a autoridade da ciência respalda e é respaldada pela autoridade do Estado" (Ayora Diaz, 2007: 153, tradução minha), cabe à pesquisa científica validar as terapias das medicinas tradicionais, apresentando evidências sobre os resultados de saúde por ela alcançados, e, para que os aspectos culturais que as desqualificam sejam depurados, essas medicinas precisam ser, portanto, submetidas ao esquadrinhamento científico. Assim, ao instituir a biomedicina como o agente que detém o poder de ativar o potencial e de aprimorar os recursos terapêuticos passivos e estáticos das medicinas tradicionais, o esforço dos organismos internacionais e do Estado para cientificizar as MTs tende a subordinar os sistemas sociomédicos indígenas à racionalidade científica.

Embora a etnomedicina esteja, em certa medida, legitimada como um recurso médico útil e alternativo, isso é somente na extensão que ela é manipulada pelo governo, pela economia da pesquisa biomédica e pela comunidade política de saúde. A etnomedicina é útil ao desenvolvimento somente na medida em que ela é cientificizada por intermédio de meios biomedicamente validados. (Greene, 1998: 651, tradução minha)

As medicinas tradicionais, portanto, não são reconhecidas pelo Estado pelo seu valor intrínseco, mas apenas na relação hierárquica que se estabelece com a ciência moderna. De acordo com Giddens (1991), não se valida uma prática por ser tradicional; em outras palavras, somente a ciência, como forma ocidental hegemônica de produção de conhecimento, é tida como a instância legítima pela qual "todos os demais saberes devem passar para estabelecer seu próprio valor" (Ayora Diaz, 2007: 135, tradução minha). Ao hierarquizar, suprimir ou silenciar os saberes considerados não válidos, a racionalidade instrumental contribui para a neocolonização cultural do saber e da vida cotidiana dos grupos socialmente subordinados.

Destarte, o Estado brasileiro não está inclinado a incorporar todas as práticas das medicinas tradicionais ao sistema oficial de saúde, mas apenas as que podem ser apreendidas pela racionalidade biomédica, como é o caso das parteiras tradicionais e/ou dos conhecimentos tradicionais sobre plantas medicinais, objeto 
de grande interesse por parte da indústria farmacêutica. Dessa forma, as bem intencionadas iniciativas das políticas de desenvolvimento das medicinas tradicionais indígenas

se convertem em um 'presente envenenado'; isto é, em ferramentas de neocolonização cultural que em sua forma mais benigna deixam sem questionar as definições do 'local' e em formas mais extremas impõe sobre distintos grupos que recebem ajuda, estruturas e formas de significação que correspondem à lógica universal da cultura do Atlântico Norte. Isto é porque frequentemente se esquecem de que essas definições têm sido formadas precisamente nos centros de poder e, ainda que negociadas e ressignificadas localmente, contêm em seu núcleo as premissas da essencialização cultural. (...) Em consequência, essa essencialização obriga a grupos (...) a silenciar-se, mimetizando e tomando as características 'desejáveis' que impõe o imaginário nostálgico dos benfeitores da cultura neocolonial. (Ayora Diaz, 2007: 139, tradução minha)

O discurso desenvolvimentista acessado pela PNPIC e pela PNPMF, ao ter como um dos seus pilares estruturantes a dicotomia entre tradição e modernidade, recorre à retórica do interesse geral da nação para justificar a iniciativa de convencer a povos e comunidades tradicionais a colaborarem com esse empreendimento. De fato, as medidas instituídas por essas políticas tendem a aumentar a capacidade de monitoramento reflexivo do Estado, principalmente, sobre os conhecimentos tradicionais relativos às plantas medicinais, já que tais conhecimentos podem contribuir para o desenvolvimento da indústria farmacêutica nacional e para o fortalecimento da economia brasileira.

Dessa maneira, a regulação das medicinas tradicionais pelas políticas públicas não apenas possibilita a sua incorporação ao SUS, mas também autoriza que os conhecimentos, as práticas e os praticantes, assim como recursos terapêuticos diversos, sejam transformados em mercadoria a ser disponibilizada no mercado mundial da saúde. A universalização da MT propiciada pela validação científica na esfera do SUS é requisito necessário para que as suas terapêuticas sejam disponibilizadas aos cidadãos e consumidores do mundo contemporâneo.

O PL do deputado Eduardo Valverde, com que se pretende estabelecer os mecanismos para regulamentar a MT, alinha-se às tendências de desenvolvimento econômico dos conhecimentos e das práticas de saúde tradicionais. Por sua vez, o PL de Janete Capibaribe, ao propor a regulamentação do exercício das parteiras - um dos praticantes das medicinas tradicionais -, também se encontra em consonância com as recomendações da OMS que estimulam os serviços de saúde a estabelecerem relações de cooperação com os praticantes das medicinas tradicionais.

O respeito mútuo entre profissionais da saúde e parteiras tradicionais seria viabilizado à medida que essas praticantes fossem profissionalizadas e passassem a ocupar uma posição subordinada na hierarquia dos serviços de atenção à saúde. 
Ou seja, que fossem transformadas em 'quase o mesmo' por meio do dispositivo da mímica colonial.

Nesse processo de regulamentação do ofício, as parteiras tradicionais seriam deslocadas do âmbito comunitário em que exercem a sua prática e reencaixadas na arena do Estado, na qual passariam a integrar os quadros burocráticos da administração governamental como funcionárias públicas. No âmbito comunitário, sua prática está sustentada pelo reconhecimento da comunidade; no contexto do Estado, só pode ser reconhecida se for cientificamente validada, qualificada e, como já dito aqui, supervisionada diretamente por representantes legítimos do modelo médico hegemônico.

A validação científica está para as terapêuticas e produtos da MT, assim como a qualificação, o credenciamento e o licenciamento estão para os seus praticantes. Dessa forma, o Estado-nação exerce o seu poder administrativo sobre as medicinas tradicionais por meio dos dois modos de vigilância: a produção, o armazenamento e o controle da informação sobre as medicinas tradicionais produzidas pela pesquisa científica; e a supervisão da qualidade dos produtos e dos serviços prestados à população pelos praticantes tradicionais. Dessa forma, o Estado estende o seu monitoramento reflexivo sobre dimensões da vida de povos e comunidades tradicionais que até então estavam à margem da vigilância exercida pelo seu aparato administrativo. Ao mesmo tempo que, ao agir em consonância com as recomendações dos organismos internacionais, contribui para a expansão da capacidade de regulação reflexiva dessas agências sobre os saberes, as práticas e os praticantes das medicinas tradicionais.

Se regulamentar significa disciplinar e supervisionar os praticantes e suas práticas, então a regulamentação é o dispositivo utilizado pelo Estado para exercer seu poder administrativo e colonial sobre o mundo da vida dos grupos socialmente subordinados. As políticas da tradição, portanto, descontextualizam e instrumentalizam saberes, práticas e os sistemas sociomédicos indígenas, tornando-os objetos regulados e universais de políticas públicas. Contudo, ao serem deslocados de seus contextos e reencaixados no âmbito do sistema nacional de saúde ou do mercado, as práticas e praticantes das medicinas tradicionais passam a ter outros sentidos e a desempenhar outras funções, distintas das observadas no local da tradição.

Ao estabelecer um conceito instrumental de medicina tradicional que permite a descontextualização de saberes, práticas, praticantes e recursos dos sistemas médicos tradicionais; ao instituir a pesquisa científica como meio de validá-los; e ao integrá-los em suas políticas públicas, o Estado constrói objetos híbridos de políticas públicas, sustentados sobre a retórica da tradicionalidade. Para o que aqui nos interessa, é suficiente mencionar que os objetos das políticas públicas são híbridos, porque os próprios discursos oficiais que as constituem, ao se apropriarem do tradicional e lhes atribuir significados específicos, também o 
são. Aqui, a tradição é definida por uma instituição moderna: o Estado-nação. No entanto, ao definir de antemão o que se entende por medicina tradicional e fixar o seu sentido, os discursos oficiais desconsideram os múltiplos entendimentos dos povos e comunidades tradicionais sobre o que para eles seria a medicina tradicional.

\section{Tradição e soberania: a fragmentação do tradicional}

Outro aspecto importante veiculado pelos discursos oficiais que recorrem à categoria 'tradicional' para caracterizar os seus objetos é a relação entre povos e comunidades tradicionais e a questão da cidadania e inclusão social. O discurso das políticas públicas brasileiras, incluindo as da saúde, acessa a problemática da inclusão social como uma condição para o exercício da cidadania. No caso da PNPIC, da PNPMF e dos PLs do deputado Valverde e da deputada Janete Capibaribe, a inclusão social se refere à caracterização, no âmbito do SUS, das práticas das medicinas tradicionais ou das parteiras tradicionais como 'profissionais' do sistema. Já a PNPCT se sustenta sobre o discurso da inclusão social e política como forma de exercício de cidadania, agora não de práticas e praticantes das medicinas tradicionais, mas sim dos próprios povos e comunidades tradicionais.

Contudo, para que essa inclusão se efetive, é necessário que se defina quem são os povos e as comunidades tradicionais alvos dessa política. Grupos extremamente diversos em termos socioculturais - indígenas, quilombolas, ciganos, pescadores, extrativistas etc. - passam a ser englobados por uma única categoria: a de povos e comunidades tradicionais. Mais uma vez o Estado exerce o seu poder simbólico ao deliberar quem são e de que forma se caracterizam esses povos e comunidades tradicionais, uma vez que, para existirem perante o Estado, é preciso nomeá-los oficialmente.

Com o desenvolvimento de políticas públicas para os povos e comunidades tradicionais, instaura-se inexoravelmente um processo de destradicionalização dessas sociedades. Nunca os tentáculos da globalização tiveram maior alcance do que agora, sob a rubrica dos direitos de cidadania. Os agentes técnico-administrativos, ao definirem o tradicional, performam o poder estatal, contribuindo para desencaixar a tradição de seus contextos originais e reencaixá-la nos cenários das políticas do Estado em que a tão almejada modernização aparece como sinônimo de desenvolvimento. Aqui, além de tardia, a modernidade também é colonial.

As políticas públicas criam possibilidades para que segmentos das populações antes invisíveis acessem os benefícios disponibilizados pelos programas e ações governamentais e também constituem mecanismos voltados para o monitoramento reflexivo dessas populações. Como afirma Giddens (2008), os direitos de cidadania estão associados a tipos de vigilância, na medida em que para reconhecer 
oficialmente esses segmentos sociais, o Estado precisa produzir informações, armazená-las e controlá-las visando à implementação de programas e ações que tragam benefícios a esses novos cidadãos coletivos. As ciências sociais, em particular a antropologia, desempenham papel fundamental no mapeamento e na caracterização de tais segmentos populacionais, contribuindo para o seu reconhecimento como sujeitos de direitos e cidadãos brasileiros. Até aqui, os povos e comunidades tradicionais existiam para si mesmos, mas não aos olhos governamentais; agora foram transformados em cidadãos que podem acessar benefícios, porém, para fazê-lo, precisam se submeter ao controle e à vigilância do Estado.

As políticas nacionais são unânimes ao reconhecer que os povos e comunidades tradicionais são detentores de saberes sobre as plantas medicinais que podem ser incorporadas ao patrimônio genético. Os interesses públicos e privados pelos conhecimentos tradicionais associados à biodiversidade, portanto, estão situados na fronteira entre a economia, o ambientalismo e a área da saúde. Por isso, todas as políticas que tratam do uso de plantas medicinais precisam considerar a MP n. 2.186-16/2001 (Brasil, 2001), que dispõe sobre o acesso ao patrimônio genético e a proteção dos conhecimentos tradicionais associados à biodiversidade.

Contudo, os princípios genéticos das plantas medicinais passíveis de serem economicamente explorados são declarados na referida MP como patrimônio da União, e não propriamente dos povos e comunidades tradicionais que utilizam plantas e animais em suas práticas terapêuticas. Portanto, a proteção que essa MP outorga aos conhecimentos tradicionais não se deve ao seu valor intrínseco, mas sim ao fato de esses conhecimentos constituírem um caminho de acesso ao patrimônio genético da União, e apenas os conhecimentos associados a esse patrimônio, com valor real ou potencial, são protegidos por essa lei. Os demais conhecimentos que informam as práticas terapêuticas são considerados patrimônio imaterial que integra, como um conjunto de traços, a cultura brasileira e que pode ser salvaguardado ao se tornar objeto de cadastro do Instituto de Patrimônio Histórico e Artístico Nacional (Iphan).

Ao diferenciar o conhecimento tradicional associado a outros saberes com os quais esses povos e comunidades operam em seu cotidiano - saberes que, na prática, são indissociáveis nos contextos locais da tradição -, o Estado instaura um processo de fragmentação e compartimentalização desses conhecimentos. No estilhaçamento do tradicional, os objetos das políticas da tradição, em consonância com a especialização de seu aparato administrativo, passam a ser distribuídos desta forma:

- O conhecimento tradicional associado ao patrimônio genético, principal interesse da União, fica a cargo do Conselho de Gestão do Patrimônio Genético (CGEN), situado no Ministério do Meio Ambiente (MMA);

- Os saberes, práticas e praticantes das medicinas tradicionais ficam a cargo do setor Saúde; 
- As concepções, rezas, rituais, costumes e tudo o que não pode ser validado cientificamente ou que não pode ser instrumentalizado são identificados como patrimônio cultural imaterial, alvo de cadastro e da salvaguarda do Iphan;

- Por fim, a política voltada para o desenvolvimento sustentável de povos e comunidades tradicionais está sob a responsabilidade do MDS e do MMA.

As ideias de inclusão social, direitos de cidadania, ampliação do acesso, integração das medicinas tradicionais, integralidade da atenção à saúde, preservação ambiental, desenvolvimento da indústria farmacêutica nacional, desenvolvimento sustentável, validação científica do tradicional, reconhecimento da sociodiversidade se apresentam como noções estruturantes dos discursos veiculados pelas políticas nacionais e internacionais. Nesse caso, as políticas públicas se apresentam como dispositivos de planificação e difusão de conceitos que contribuem para a consolidação da soberania do Estado brasileiro, já que permitem uma relativa homogeneidade discursiva oficial, mesmo diante da fragmentação dos conhecimentos e práticas tradicionais. A noção de tradição que qualifica objetos das políticas públicas, também é forjada pelo discurso estatal e, por isso, reflete os estereótipos coloniais difundidos no imaginário ocidental.

As políticas públicas só podem reconhecer e validar a tradição que organiza o 'mundo da vida' dos povos e comunidades tradicionais deslocando conhecimentos, práticas e praticantes de seus contextos de origem. Só que, ao passarem pela fronteira existente entre o local e o nacional/internacional, os elementos do tradicional são esvaziados do seu conteúdo semântico primordial. Como objetos híbridos e deslocados de políticas públicas, passam a veicular outros sentidos e valores, agora associados à ideia de cidadania constitutiva do moderno Estado brasileiro.

\section{As políticas da tradição e a modernidade: a reconfiguração do local}

Na medida em que o Estado-nação é uma instituição característica da modernidade, os discursos e as definições sobre a tradição constituem um fenômeno reflexivo marcadamente moderno, pois está sustentado pela produção de conhecimentos científicos. Dessa maneira, o próprio processo de integração das medicinas tradicionais ao sistema oficial de saúde é configurado pela dinâmica de desencaixe (Giddens, 1991) que desloca saberes, práticas e praticantes dos seus contextos locais e os reencaixa em outras condições de tempo e lugar - o campo das políticas públicas.

Os discursos oficiais, ao irromperem em distintas localidades, afetam diretamente a vida das pessoas e têm a virtude de instituir múltiplas realidades translocais, reordenando as relações socioculturais e conectando-as a uma ordem 
mundial mais abrangente. O local, dessa forma, é atravessado por forças globalizadoras que advêm de lugares distantes. Por ter o poder de deslocar, a modernidade permite que relações, instituições, saberes e práticas localmente situadas, sejam inseridos em cenários cada vez mais mundializados. É justamente o processo de ocidentalização da tradição, por meio de sua cientificização, que permite a emergência dos objetos das políticas públicas como híbridos culturais.

Baseado no processo de produção colonial da diferença, o Estado define o que são as medicinas, as práticas, as parteiras, o conhecimento, os povos e as comunidades tradicionais, assim como o que é ser índio, e o que é medicina tradicional indígena. Isso porque as políticas públicas, não raramente, são elaboradas a partir da fantasia da diferença colonial, que ao mesmo tempo reforça e subordina os grupos sociais, obrigando-os a imitar aquelas imagens fantasmáticas da civilidade ou da cidadania. Assim, o Estado cria categorias para discriminar e mapear as populações a serem submetidas ao seu poder administrativo.

Os discursos veiculados pelas políticas públicas cunham o tradicional para qualificar os seus objetos e conceituá-los. Entretanto, os agentes situados em posições subordinadas, os sujeitos-objetos alvos das políticas públicas, criam contraestratégias para manter a sua autonomia ante as investidas regulatórias do Estado. $\mathrm{Na}$ dialética do controle, as lideranças indígenas passam a se apropriar desses discursos como forma de acessar os benefícios disponibilizados pelo Estado, atendendo aos seus interesses de desenvolvimento, ou melhor, de developman (Sahlins, 1997a). Com todas as forças e influências exercidas pelas políticas públicas sobre o local, os agentes sociais ainda assim constroem as suas localidades. Ao se apropriarem das categorias universalizadas veiculadas pelos discursos oficiais, os povos indígenas atribuem a tais noções novos sentidos e lhes destinam um lugar específico em meio aos sistemas de significados que informam as suas ações.

Se assim é, então, ao transformar as coisas e os sujeitos em tradicionais objetos de políticas públicas, o movimento por elas desencadeado se faz cíclico: os povos indígenas voltam a se reapropriar desses objetos com base em seus próprios interesses de desenvolvimento, atribuindo-lhes outros sentidos, que não são mais os originais, mas nem por isso têm necessariamente o mesmo significado veiculado pelas políticas públicas. Assim, as diferenças culturais são redimensionadas e novos locais de cultura emergem a partir da indigenização das políticas públicas estabelecida na relação entre os povos indígenas e o Estado. Talvez, por isso, grandes partes dos programas de Estado não alcancem os resultados inicialmente planejados, pois, no âmbito local, as forças que configuram a realidade sociocultural estão organizadas sobre outros princípios e valores.

As reuniões de parteiras, pajés e agentes indígenas de saúde irromperam no Alto Juruá em virtude da política pública desenvolvida pela Área de Medicina Tradicional Indígena. Por terem sido dialogicamente orientados, esses eventos comunicativos possibilitaram que os seus participantes tanto refletissem sobre outras 
ações realizadas na região quanto se apropriassem e indigenizassem as próprias reuniões. No próximo capítulo, aparecem algumas informações para caracterizar esse contexto comunicativo que propiciou a emergência dos discursos indígenas sobre gestação e parto, considerados ao longo do empreendimento interpretativo aqui realizado.

1 Conferência Internacional sobre Cuidados Primários de Saúde. Alma-Ata, URSS, 1978.

2 Até o advento da Constituição de 1988, a assistência à saúde indígena era prestada pelo órgão indigenista oficial (de 1910 até 1967 foi de responsabilidade do Serviço de Proteção ao Índio - SPI); a partir de então ficou a cargo da Funai, órgão que substituiu o SPI em sua missão.

3 A PNASPI foi regulamentada pelo Decreto n. 3.156, de 27/8/1999 (Brasil, 1999a), que dispõe sobre as condições de assistência à saúde dos povos indígenas; pela MP n. 1.911-8, que transfere da Funai para a Funasa a atribuição de assistência à saúde indígena; e pela Lei n. 9.836, de 23/9/99 (Brasil, 1999b), que estabelece o subsistema de Atenção à Saúde Indígena (Brasil, 2002: 5).

4 Este PL foi apensado ao PL n. 4.842/1998, proposto pela então deputada federal Marina Silva, e dispõe sobre o acesso a recursos genéticos e produtos derivados e dá outras providências.

5 PL apresentado e discutido na audiência pública sobre a "Situação das Parteiras Tradicionais", realizada na Câmara dos Deputados no dia 13/11/2007 em Brasília, DF.

6 Em 2007, o PL estimava que das sessenta mil parteiras atuantes no Brasil, 45 mil se encontram no Norte e Nordeste, realizando, aproximadamente, 450 mil partos ao ano.

7 Esse mesmo decreto delega à Comissão Nacional de Desenvolvimento Sustentável de Povos e Comunidades Tradicionais, composta por representantes de diferentes setores do governo e também da sociedade civil organizada, a responsabilidade pela implementação da PNPCT.

8 A MP institui, com caráter normativo e deliberativo, o Conselho de Gestão do Patrimônio Genético (CGEN), que, criado no âmbito do Ministério do Meio Ambiente (MMA), é composto por representantes da administração federal que detêm competência sobre as ações de que trata a MP. 


\section{Contexto de Emergência das Vozes Indígenas: os encontros de parteiras, pajés e AISs no Alto Juruá}

Os encontros entre parteiras, pajés e agentes indígenas de saúde (AISs) que aconteceram na região do Alto Juruá, no estado do Acre, configuram o contexto de emergência dos discursos indígenas analisados. Esses encontros fizeram parte do projeto de pesquisa-ação Valorização e Adequação dos Sistemas de Parto das Etnias do Acre e Sul do Amazonas (Projeto Acre), executado em parceria pela Área de Medicina Tradicional Indígena (AMTI) e o Instituto Olhar Etnográfico, contando com a participação de lideranças do movimento de mulheres indígenas da região. Na esfera da AMTI, esse projeto está situado no eixo sistemas de parto, por abordar assuntos relativos aos saberes, práticas e cuidadores indígenas envolvidos no cuidado com a gestação, o parto e o resguardo pós-parto nas diversas etnias abarcadas pela ação. Aqui o nosso objetivo é, justamente, apresentar o contexto de emergência dos discursos indígenas que serão trazidos à cena pela análise antropológica nos próximos capítulos.

Desde a década de 1980, observa-se crescente preocupação com a saúde e o bem-estar de mulheres dos países em desenvolvimento (OMS, 1985). Os organismos internacionais incentivam os Estados nacionais a desenvolverem políticas adequadas para a assistência integral à saúde da mulher. No Brasil, a incorporação da atenção à saúde da mulher no Sistema Único de Saúde (SUS) constitui uma bandeira de luta de movimentos sociais, particularmente do movimento feminista e de mulheres. O poder público, então, viu-se diante do imperativo de criar políticas universais e equânimes de saúde que atendessem a diversidade cultural, econômica e epidemiológica, característica do universo populacional das mulheres brasileiras. As mulheres indígenas em sua multiplicidade étnica, por exemplo, constituem um dos segmentos culturalmente diversos que precisam ser considerados por essas políticas.

Adequar os programas de atenção à saúde da mulher às múltiplas realidades socioculturais e epidemiológicas dos povos indígenas de modo a efetivar o princípio de atenção diferenciada previsto na Política Nacional de Atenção à Saúde Indígena (PNASPI) representa um desafio a ser enfrentado pelos setores responsáveis pela gestão da saúde indígena. Para fazer frente a esse desafio, em 2004 foi criado um grupo de trabalho composto por técnicos do Departamento de Saúde Indígena 
da Fundação Nacional de Saúde (Desai/Funasa), do Ministério da Saúde (MS), da Fundação Nacional do Índio (Funai) e por lideranças indígenas para formular um protocolo de atenção integral à saúde da mulher indígena. Apesar das inúmeras tentativas governamentais de elaboração dessa normativa, até o momento não foi consolidado um modelo de atenção à saúde das mulheres indígenas que contemplasse as suas especificidades culturais.

O Projeto Acre passou a ser forjado justamente no momento em que os debates sobre a necessidade de criação de uma política específica de atenção à saúde da mulher indígena foram iniciados. Portanto, optei por analisar os discursos proferidos nos eventos comunicativos que aconteceram no contexto do referido projeto em razão da pertinência e da complexidade da problemática associada à necessidade de desenvolvimento de um modelo diferenciado de atenção à saúde da mulher indígena, pautado no respeito às diferenças culturais e no reconhecimento dos sistemas indígenas de atenção ao parto com os quais as comunidades indígenas operam, bem como de suas interações com o sistema oficial de saúde.

\section{O Projeto Acre em linhas gerais}

O Projeto Acre foi delineado a partir das solicitações que o movimento de mulheres indígenas do Acre fez à Área de Medicina Tradicional Indígena (AMTI), Projeto Vigisus II. Ao procurar a AMTI, as mulheres indígenas estavam em busca de financiamento para darem continuidade aos cursos de aperfeiçoamento de parteiras tradicionais indígenas que vinham realizando na região desde 2000. Entretanto, por não prever em seu plano de ação a capacitação de praticantes das medicinas tradicionais indígenas, a gerência da AMTI sugerira que a proposta indígena fosse redimensionada: ao invés de fomentar os cursos de capacitação de parteiras, promoveria a troca de experiências entre alguns dos cuidadores indígenas - parteiras, pajés e agentes indígenas de saúde - envolvidos no trabalho com a gestação, parto e pós-parto. Com isso, ao mesmo tempo que a perspectiva individualizante - que tomava as parteiras indígenas como únicas especialistas nos cuidados com as gestantes, parturientes e recém-nascidos - era reposicionada, o alerta recaía sobre a dimensão sociocultural dos sistemas de atenção ao parto vigentes nos contextos comunitários indígenas.

Dessa forma, ao instituir os encontros entre parteiras, pajés e AISs como a principal atividade do projeto, desejava-se contribuir para a valorização e fortalecimento dos cuidadores indígenas, de seus conhecimentos e práticas relacionados ao cuidado com a gestação, o parto e o pós-parto, ${ }^{1}$ uma vez que esses eventos comunicativos constituiriam espaços propícios ao diálogo e à reflexão indígena sobre os processos de desvalorização dos saberes e práticas tradicionais de saúde e 
consequente medicalização do processo de gestação, parto e puerpério vivenciada pelas comunidades indígenas do Acre e sul do Amazonas.

Ao longo das últimas décadas vem ocorrendo um paulatino abandono de certas práticas tradicionais referentes aos cuidados tomados com a gestação, parto e pós-parto. Esse processo tem como consequência a afluência cada vez maior das mulheres indígenas aos postos de saúde e hospitais (...) e a desvalorização dos saberes tradicionais referentes aos sistemas de parto indígenas. (Ferreira, 2004: 5)

A produção de conhecimentos etnográficos sobre os sistemas de parto indígenas e sobre o próprio processo participativo do projeto também foi estabelecida como um dos objetivos desse empreendimento. A intenção era criar subsídios para a construção de estratégias de articulação das medicinas indígenas aos serviços de saúde e para a formulação de políticas públicas culturalmente adequadas de atenção à saúde das mulheres indígenas. Para alcançar esses objetivos, a equipe de execução do projeto adquiriu uma composição interétnica, composta por antropólogas, a quem coube o registro etnográfico dos eventos comunicativos, e também por lideranças indígenas, que ficaram responsáveis por articular com as comunidades indígenas e conduzir as estratégias metodológicas para o desenvolvimento das ações.

Apesar de se prever no projeto a realização de seis reuniões de parteiras, pajés e AISs em aldeias situadas nas regiões do Alto Juruá e no Alto Purus, ${ }^{2}$ para fins da reflexão aqui empreendida, recorre-se aos discursos indígenas proferidos nos eventos que ocorreram no Alto Juruá. Tais discursos, para a análise antropológica, constituem dados privilegiados no processo de emergência dialógica da medicina tradicional indígena e noções associadas - parteiras e pajés, pré-natal tradicional etc. -, bem como na construção dos novos sentidos e papéis atribuídos às políticas da tradição quando apropriadas e indigenizadas pelos povos indígenas dessa região.

\section{Situando os encontros no Alto Juruá}

Os encontros entre parteiras, pajés e AISs da região do Alto Juruá, estado do Acre, constituíram eventos comunicativos socialmente situados no campo interétnico da saúde indígena. Esses eventos surgiram a partir das relações estabelecidas entre os povos indígenas, representados por suas lideranças, o Estado-nação e os organismos internacionais, representados pela AMTI. Nesse sentido, os encontros se configuram como contextos dialógicos emergentes, propiciados pelas novas formas que as relações interétnicas vêm assumindo no decorrer da história de contato. 


\section{Organização, local e participantes}

As reuniões aconteceram entre os meses de janeiro e março de 2006 e foram celebradas nas aldeias de Campinas, TI Katukina de Campinas, município de Cruzeiro do Sul; do Caucho, na TI Kaxinawa Igarapé do Caucho, em Tarauacá; e da Morada Nova na TI Kaxinawa/Katukina, município de Feijó. Nesses eventos, participaram parteiras, pajés e AISs dos povos Katukina, Yawanawa, JaminawaArara, Nawa, Nukini, Arara, Kaxinawa, Shanenawa, Ashaninka e Kulina. A maioria dos participantes, portanto, pertencia aos povos Pano e, dentre esses, os Kaxinawa estavam em maior número. ${ }^{3}$ Por isso, embora os encontros contassem com a participação Ashaninka (Arwak) e Kulina (Arawa), os discursos privilegiados pela análise antropológica empreendida são os veiculados pelos participantes pano.

Figura 1 - Reuniões no Alto Juruá

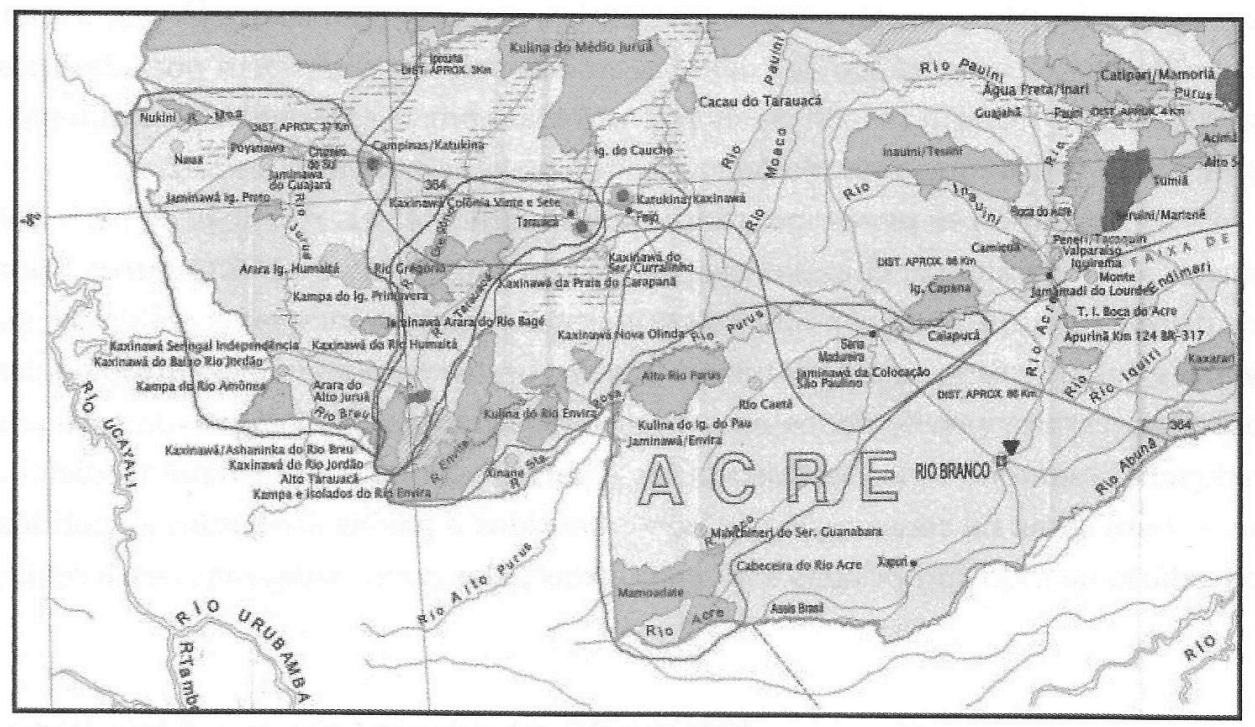

Fonte: Perez Gil, 2007: 25.

Para organizar os encontros no Alto Juruá, a equipe de execução do projeto contou com o apoio das organizações indígenas regionais. Os convites enviados às comunidades indígenas para participarem dos eventos, por exemplo, foram realizados por essas organizações, geralmente, via radiofonia. Ao todo, foram convidadas a participar 27 Terras Indígenas (TIs) da região Alto Juruá, mas apenas vinte enviaram participantes. Nos contatos realizados, foi solicitado aos caciques que indicassem, por cada TI, uma parteira, um pajé e um AIS para participarem dos eventos. No entanto, outras pessoas interessadas em participar também se fizeram presentes nessas reuniões, tais como caciques, professores, agentes indígenas de saneamento 
(AISANs), agentes agroflorestais, agentes de medicina tradicional e lideranças de mulheres indígenas de cada localidade. No quadro a seguir, encontra-se um resumo da participação das parteiras, pajés, AISs, lideranças e representantes das mulheres indígenas nos encontros.

Tabela1 - Resumo da participação indígena nas reuniões

\begin{tabular}{|c|c|c|c|c|c|c|c|c|c|}
\hline \multirow{2}{*}{ Aldeia/TI } & \multirow{2}{*}{ Período (2006) } & \multirow{2}{*}{ n. TIs } & \multirow{2}{*}{ Etnias participantes } & \multicolumn{5}{|c|}{ n. participantes } & \multirow{2}{*}{ Total } \\
\hline & & & & $\mathrm{P}$ & $\mathrm{Pj}$ & AIS & $\mathrm{L}$ & $\mathrm{RM}$ & \\
\hline $\begin{array}{l}\text { Campinas/ TI } \\
\text { Katukina de } \\
\text { Campinas } \\
\end{array}$ & $\begin{array}{c}15 \text { a } 19 \\
\text { de fevereiro }\end{array}$ & $7(11)$ & $\begin{array}{l}\text { Katukina, Jaminawa, } \\
\text { Jaminawa-Arara, Arara, } \\
\text { Kaxinawa, Nawa, Nukini }\end{array}$ & 14 & 5 & 8 & 3 & 8 & 38 \\
\hline $\begin{array}{c}\text { Caucho/TI Igarapé } \\
\text { do Caucho }\end{array}$ & $\begin{array}{c}13 \text { a } 17 \\
\text { de março }\end{array}$ & $6(9)$ & $\begin{array}{l}\text { Kaxinawa, Yawanawa, } \\
\text { Katukina, Ashaninka, }\end{array}$ & 31 & 3 & 16 & 5 & 3 & 58 \\
\hline $\begin{array}{c}\text { Morada Nova/ TI } \\
\text { Katukina/Kaxinawa }\end{array}$ & $\begin{array}{c}27 \text { a } 31 \\
\text { de março }\end{array}$ & 7 & $\begin{array}{c}\text { Shanënawa, Kaxinawa, } \\
\text { Ashaninka, Kulina }\end{array}$ & 29 & 9 & 13 & 10 & 3 & 64 \\
\hline
\end{tabular}

$\mathrm{P}=$ parteiras, $\mathrm{Pj}=$ pajés, $\mathrm{L}=$ líderes, $\mathrm{RM}=$ representantes de mulheres

Fonte: Perez Gil, 2007: 26.

Na reunião da aldeia de Campinas, os Katukina eram maioria em função de o evento ter sido sediado na TI desse povo. Já nas aldeias do Caucho e da Morada Nova, os Kaxinawa estavam em maior número. De qualquer forma, a grande heterogeneidade linguística e cultural dos povos indígenas do Alto Juruá esteve representada nesses eventos comunicativos. "As tradições culturais particulares, as experiências históricas, assim como as decisões em relação à política e às estratégias referentes aos mais diversos aspectos da vida são circunstâncias que contribuem a desenhar um panorama sumamente variado" (Instituto Olhar Etnográfico, 2006b: 8).

\section{Conteúdo programático e dinâmica dos encontros}

Cada um dos encontros de parteiras, pajés e AISs durou cinco dias: os três primeiros foram reservados para o debate entre os participantes indígenas sobre os temas contemplados na programação; os dois últimos foram destinados ao diálogo entre os indígenas e os profissionais da saúde das equipes multidisciplinares que atendem às populações indígenas da região. Nas aldeias de Campinas e da Morada Nova, as reuniões aconteceram no espaço do cupishawa (chapéu de palha), ${ }^{4}$ já na aldeia do Caucho o evento foi realizado no prédio da escola.

A programação dos encontros foi elaborada com base na experiência prévia das lideranças que participavam da equipe de execução do projeto e da organização 
dos cursos de aperfeiçoamento de parteiras tradicionais indígenas e, além de ser utilizada como um roteiro para conduzir as discussões, foi revista a cada um dos eventos realizados. Sua primeira versão elaborada para a reunião que aconteceu na aldeia de Campinas foi:

Dia 1 - Manhã: Abertura da Reunião - apresentações culturais do Projeto Acre e dos participantes. Tarde: Avaliação dos Cursos de Aperfeiçoamento das Parteiras Tradicionais Indígenas.

Dia 2 - Manhã: Perfil da parteira. Tarde: Relação entre parteiras, pajés e AISs nos cuidados com a saúde materno-infantil.

Dia 3 - Manhã: Parto na aldeia e parto na cidade: vantagens e desvantagens. Tarde: Discussão sobre o pré-natal, identificação de problemas da grávida e da parturiente e encaminhamentos aos serviços de saúde.

Dia 4 - Manhã: Recepção dos profissionais de saúde e discussão sobre os problemas enfrentados na atenção à saúde materno-infantil. Tarde: Percepção dos profissionais e indígenas sobre os serviços de saúde.

Dia 5 - Manhã: Sistematização e avaliação da reunião. (Instituto Olhar Etnográfico, 2006a)

Nos encontros que ocorreram na TI do Caucho e na aldeia Morada Nova, foram agregados alguns tópicos à programação: na do Caucho foi incluído um debate sobre as iniciativas de valorização dos conhecimentos tradicionais realizadas pelas comunidades indígenas locais e sobre o "pré-natal tradicional"; na reunião da Morada Nova, além dos temas já agregados à reunião do Caucho, foi indagado aos participantes o conceito de medicina tradicional (Instituto Olhar Etnográfico, 2006a: 85).

A condução dos debates foi realizada, principalmente, pelas lideranças indígenas que integraram a equipe interétnica de execução dessas atividades, não significando que as antropólogas tenham desempenhado papel menos importante. Pelo contrário, elas exerceram sua influência sobre as próprias lideranças ao sugerir questões a serem colocadas para a audiência; ao responder às solicitações das lideranças, esclarecendo ou validando alguns dos seus enunciados; ou mesmo ao se dirigirem diretamente aos participantes para esclarecer alguma dúvida ou problematizar algum aspecto levantado na discussão. Além disso, tiveram papel fundamental na avaliação e redimensionamento da programação e da metodologia utilizada em cada evento.

Todas as reuniões abriam com uma apresentação cultural: brincadeiras, cantos ou danças das etnias representadas eram performadas por alguns participantes dos eventos. Logo em seguida a equipe de execução expunha os objetivos da ação e, posteriormente, repassava a palavra para que as pessoas se apresentassem. Cada vez que os trabalhos eram retomados depois das pausas para as refeições, 
mais apresentações culturais eram feitas, de modo a permitir que todos os povos presentes pudessem expor um pouco da sua 'cultura'.

Após a abertura, os temas a serem tratados no dia eram escritos em algum quadro, ou mesmo em cartazes, ficando disponíveis aos participantes. As indígenas da equipe, então, davam início aos trabalhos apresentando os pontos a serem debatidos.

Bom, então a programação que a gente vai fazer hoje é isso aqui, olha... Isso aqui que a antropóloga escreveu aqui. Pra quem não sabe ler, não se preocupe que a gente pode ler pra vocês. Todo dia vai ter essa programação. Hoje nós vamos estar falando da 'avaliação do curso de aperfeiçoamento das parteiras indígenas'. E, à tarde, vai ser o perfil das parteiras, dos pajés, dos AISs. Então, à tarde, nós vamos saber o que é a palavra perfil. (...) Tá certo?

Audiência: Tá!

O tema da avaliação dos cursos de parteiras foi o primeiro a ser tratado em todas as reuniões realizadas no Alto Juruá. Já na aldeia de Campinas, as lideranças indígenas da equipe incentivaram também a discussão sobre o reconhecimento profissional e a demanda por contrato remunerado para as parteiras, mesmo não se encontrando esse ponto na programação oficial do evento. Porém, esse tópico não voltou a ser explorado de forma sistemática nos outros eventos.

Geralmente, as discussões realizadas nos encontros envolveram todos os seus participantes que, sentados no chão ou em cadeiras, posicionavam-se no espaço de modo a formar um grande círculo. Em Campinas e no Caucho, os participantes também fizeram grupos de trabalhos que mesclavam parteiras, pajés e AISs de diferentes etnias para trocarem experiências sobre temas específicos, tais como o pré-natal e os cuidados com os recém-nascidos. Os resultados dos debates realizados nesses grupos menores, por sua vez, eram sistematizados em cartazes para serem apresentados ao grande grupo. No percurso das atividades, a equipe decidiu não utilizar a metodologia dos trabalhos de grupo na reunião da Morada Nova "pelo fato dos cartazes não darem conta da riqueza das falas" (Instituto Olhar Etnográfico, 2006a: 29).

Fortemente sugerido pelas lideranças indígenas, outro recurso didático empregado foram as dinâmicas aprendidas durante os cursos de capacitação de parteiras tradicionais, promovidos pelo Ministério da Saúde e pela organização não governamental (ONG) Curumim, oportunizados entre 2000 e 2003. "A justificativa fornecida para tais atividades foi a de que as reuniões são extremamente cansativas para as pessoas e que estas precisavam de momentos de relaxamento" (Instituto Olhar Etnográfico, 2006a: 28). De acordo com as antropólogas, esses procedimentos e outros aspectos formais que caracterizaram esses eventos comunicativos são resultados das influências do contato com o "mundo dos brancos". 
Podemos citar a este respeito: crachá de identificação, estabelecimento de horários para as conversas e alimentação, apresentação da programação, solicitação de materiais para realizar anotações e realização de dinâmicas. (...) Estes aspectos do 'mundo dos brancos' convivem com outros tradicionais, fornecendo as reuniões características muito peculiares. Alguns elementos tradicionais presentes foram: o uso do rapé e do tabaco, as pinturas de jenipapo durante as conversas, a presença de crianças, a circulação de alimentos da aldeia (ingá, amendoim, bananas, pupunha, cana) (...) a elaboração de ornamentos, a celebração de rituais de ayahuasca (...) e a realização de cantos, danças e brincadeiras tradicionais dos vários grupos presentes. (Instituto Olhar Etnográfico, 2006a: 25-26, grifo do original)

Mais do que remeter a uma dicotomia entre a tradição indígena e o mundo dos brancos (Instituto Olhar Etnográfico, 2006a), os participantes indígenas, em sua agência criativa, combinam práticas provenientes de diferentes universos socioculturais de tal modo que fazem com que essas reuniões surjam como eventos comunicativos híbridos. Os elementos provenientes do mundo do branco são apropriados e indigenizados pelos indígenas, ao passo que aqueles classificados como tradicionais, ao deslizarem pelas fronteiras das diferenças culturais, assumem novos significados e funções nesse local de cultura emergente. Esse é o caso dos cantos e danças encenados pelos participantes indígenas que, durante as reuniões, adquiriram o status de 'apresentação cultural', status que eles certamente não têm nos contextos comunitários em que são praticados. Como 'apresentação cultural', os cantos e danças se constituíram numa maneira de os participantes falarem de si e de sua diferença, demonstrando aos demais que também têm 'cultura'.

\section{A diversidade e a alteridade constitutivas dos encontros}

Dez etnias falantes de diferentes línguas - pertencentes às famílias linguísticas pano, arwak e arawa - estiveram representadas nos encontros de parteiras, pajés e AISs, caracterizando esses eventos como multiétnicos e multilíngues. De um lado, temos os Nukini e Nawa, que têm o português como língua materna e não falam mais a língua indígena; do outro, os Ashaninka e Kulina com pouco domínio do português. Entre esses polos, encontram-se os povos bilíngues, tais como os Yawanawa, Kaxinawa, Katukina, Shanenawa (Instituto Olhar Etnográfico, 2006a: 14).

Mediante essa diversidade linguística, o português foi instituído como língua franca dessas reuniões. No entanto, alguns participantes sequer dominavam o português, demandando que a equipe de execução recorresse ao dispositivo da tradução a fim de viabilizar a construção de um entendimento compartilhado entre os participantes do evento. Eram convocados para fazer a tradução, quando necessário, os presentes que apresentavam maior domínio da língua nativa e do 
português. Ao sintetizar as longas narrativas de parteiras ou pajés, os tradutores também filtravam aquilo que poderia ser repassado ou não aos não índios, decidindo quais conhecimentos poderiam ser amplamente revelados e quais deveriam ser mantidos em segredo.

A diversidade de pertencimentos étnicos e socioculturais dos participantes dessas reuniões influenciou nas relações de proximidade e distância estabelecidas entre eles, gerando "sensações de estranhamentos e de confrontos entre os saberes, e muita reflexão" (Instituto Olhar Etnográfico, 2006a). Na reunião de Campinas, por exemplo, as mulheres katukina se mantiveram distanciadas das demais por perceberem a si próprias como "mais tradicionais" do que as outras participantes. Sinais diacríticos, tais como o uso da língua indígena ou a menção aos costumes tradicionais e a resistência em aderir aos serviços de saúde do branco, foram acessados pelos Katukina para demarcar as fronteiras étnicas e simbólicas da diferença cultural frente aos representantes de outros povos indígenas presentes nesses eventos.

Esta situação criou alguns constrangimentos, já que em determinado momento as mulheres katukina reclamaram que não queriam mais trabalhar em grupos que misturassem pessoas de diferentes etnias porque elas 'falavam coisas de índio', enquanto as outras 'falavam coisas de branco'. (...) Mostraram-se incomodadas, ainda, ante a ideia de que pessoas de outros grupos que 'tinham perdido sua cultura' estivessem aprendendo e levando consigo aspectos da cultura katukina. (Instituto Olhar Etnográfico, 2006a: 43-44, grifos do original)

Na aldeia do Caucho, a predominância de falantes da língua pano facilitou o entendimento mútuo entre os seus participantes. Em muitas ocasiões, as traduções foram dispensadas. Já na aldeia Morada Nova, por acolher participantes das famílias linguísticas pano, arwak e arawa, houve alguns mal-entendidos. Os Kulina "acharam que duas mulheres huni kuin estavam caçoando deles (...), sentiram-se ofendidos, e sua presença diminuiu ao longo do evento" (Instituto Olhar Etnográfico, 2006a: 68).

Por outro lado, as interações que ocorreram durante essas reuniões também foram recortadas por questões de gênero. Para as antropólogas da equipe de execução, os eventos se constituíram como um espaço feminino tanto pela existência de maior número de participantes mulheres quanto pela natureza dos temas tratados.

Nesse sentido, a reunião inverteu a lógica predominante, na qual os homens são escutados e protagonizam as ações que as instituições dos nawa [brancos] desenvolvem em favor das populações indígenas. Aqui, as mulheres assumiram o protagonismo colocando os homens em segundo plano. (...) Contudo, é necessário destacar que a participação dos homens foi importante, de um lado, para que escutassem a voz feminina em um espaço de legitimidade que as mulheres dificilmente acessam e, de outro, porque proporcionou uma reflexão conjunta sobre 
os temas propostos. Afinal, como ficou claro na reunião, as práticas e problemas associados aos processos de gestação, parto e pós-parto são incumbências da comunidade como um todo e não apenas das mulheres. (Instituto Olhar Etnográfico, 2006a: 42)

As interações estabelecidas entre os participantes dessas reuniões - marcadas pelos distintos pertencimentos étnicos e pela identidade de gênero, assim como pelas múltiplas posições que cada um ocupava - são apenas uma das faces da alteridade constitutiva desses eventos comunicativos. Outra dimensão da alteridade são as instituídas entre esses mesmos povos indígenas e os brancos, principalmente, aqueles vinculados ao Estado brasileiro. Relação essa que, por ter viabilizado a emergência das reuniões de parteiras, pajés e AISs como novos locais de cultura, merece ser analisada com um pouco mais de atenção.

Ao incluir o universo dentro do próprio esquema cultural (...) um povo abre um espaço definido na reprodução de sua comunidade imediata a seres e coisas que estão além dela. Deuses ou inimigos, ancestrais ou afins, de várias formas, os Outros representam a condição necessária da existência de uma sociedade. Assim, na medida em que seus sistemas de construção simbólica do Outro constituem o quadro e a condição de possibilidade de sua autodefinição, as sociedades indígenas, ao confrontarem os brancos, têm necessariamente que passar por um processo de redefinição identitária no qual são reconstituídas as fronteiras tradicionais da alteridade, desestabilizadas por esse encontro. (Albert, 2002: 13)

Estudiosos de grupos pano acreditam que eles mantêm entre si certa unidade sociocultural (Erikson, 1992; Santos-Granero G Barclay, 1998), sendo os Kaxinawa o povo mais conhecido em termos antropológicos (Aquino, 1994; Deshayes G Keifenheim, 1994; Keifenheim, 1990; Kensinger, 1995; Lagrou, 1998; McCallum, 1989). Segundo eles, os Pano têm uma atração pelos estrangeiros e todos os tipos de 'outro' que habitam o seu cosmos, assim como pelas coisas advindas de seus mundos distantes (Lagrou, 2007; Erikson, 2002). "Os bens dos brancos são valorizados, e sua aquisição é lema do jogo das relações interétnicas concretas" (Gallois, 2002: 229).

Nesse contexto, os brancos são apenas um tipo de outro que habita o mundo entre outros. É com o termo nawa que os povos pano se referem ao outro branco. No entanto, há certa ambiguidade com relação à definição de fronteiras entre o 'eu' e o 'outro': o termo nawa também pode significar povo, quando usado como etnônimo atribuído a outros grupos: caxi (morcego); yawa (anta) etc. (Lagrou, 2007). "Nas línguas pano, um mesmo conceito pode ocupar diferentes posições numa escala que vai do polo da completa alteridade e hostilidade ao polo do 'nós', incluindo, aqui, o 'eu', denotando pertencimento a uma subdivisão que define o interior da própria comunidade" (Lagrou, 2007: 160). 
Dessa forma, podemos reconhecer dois níveis de relações de alteridades constitutivas dos encontros de parteiras, pajés e AISs: o primeiro se remete às relações estabelecidas entre os participantes vinculados a diferentes povos indígenas que habitam a região do Alto Juruá; o segundo trata das relações entre esses povos indígenas e os brancos. Se por um lado, o segundo nível pode ser considerado condição para o 'acontecer' desses eventos comunicativos, por outro, as relações de alteridade do primeiro nível se diluem quando esses povos aderem à identidade englobante de indígenas em oposição ao outro comum: o branco-nawa.

Para compreender o modo como os povos indígenas que participaram das reuniões do Alto Juruá se relacionam entre si e com o outro-branco, é importante se ter em mente que, nessas sociedades, as relações de alteridade são constitutivas da pessoa pano. É por meio dessas relações e pelos seus efeitos cumulativos que a pessoa é fabricada - o 'eu é constituído pelo outro'.

A importância da alteridade para a constituição do eu recebe uma inflexão especial entre os Pano (...). Os Pano são tão explícitos com relação à regra que diz que o `eu é constituído pelo outro', que têm sido considerados especialmente interessantes para pensar esta modalidade especificamente amazônica de se relacionar com o outro. (Lagrou, 2007: 61-62)

No caso Kaxinawa, as noções utilizadas para conceber os outros fazem referência tanto às categorias de alteridade quanto às da identidade. Nesse contexto ontológico, a incorporação do outro por esses povos indígenas faz com que passem a ser reconhecido como parte do eu. Segundo Lagrou (2007: 533),

As ideias kaxinawa sobre similaridade e diferença focalizam o corpo e o modo de sua produção. Por esta razão, identidade étnica e diferença serão expressas em termos de como se vive e de como o corpo é modelado através do contato com outros, através da convivialidade e partilha de experiências com as pessoas com as quais se vive ou que são encontradas nas viagens.

Ao serem constitutivas da própria pessoa, as relações de alteridade influenciam nos "processos de subjetivação, do tornar-se sujeito, através do processo de tornar-se parcialmente outro, e a subjetividade do eu é significativamente aumentada pelo contato íntimo, e a eventual incorporação do outro (seja este um inimigo, espírito, animal ou planta)" (Lagrou, 2007: 61-62). Para Erikson (2002), entre os povos pano, a imagem de si está vinculada à imagem dos outros. 


\section{Situando as parteiras, os pajés e os AISs: a intermedicalidade como contexto}

Os encontros de parteiras, pajés e AISs, apesar de terem acontecido em aldeias indígenas, foram viabilizadas a partir de negociações estabelecidas entre agentes governamentais situados em outros lugares que, ao ocuparem diferentes posições, transitaram por distintas dimensões - local, nacional e internacional. Dessa forma, a atuação de outros-ausentes para propiciar o 'acontecer' desses encontros - como a da então gerente da AMTI, que participou no redimensionamento da proposta do Projeto Acre - acabaram por influenciar a própria configuração que esses eventos adquiriram. Essa situação, por sua vez, só se torna possível com o advento da modernidade que, ao permitir que discursos proferidos em lugares distantes irrompam em diferentes locais de cultura, conectando-os à ordem mais abrangente das políticas públicas, redimensionando as relações sociais e transformando-os em contextos comunicativos translocais (Ayora Diaz, 2007).

As reuniões constituíram o cenário de uma multiplicidade de falas proferidas por agentes com diversos pertencimentos étnicos, ocupantes de diferentes posições, distribuídas tanto no interior de suas comunidades quanto no espaço fronteiriço de negociações interétnicas estabelecidas com o Estado-nação. Desse modo, os discursos veiculados durante esses eventos, mesmo tendo sido enunciados por indígenas, partiram de distintas posições, tais como: lideranças indígenas da equipe de execução dos encontros; parteiras, pajés e AISs; AISANs, agentes agroflorestais, agentes de medicina tradicional e professores; representantes regionais das mulheres indígenas; caciques e representantes de organizações indígenas regionais; e também antropólogos.

Entretanto, as vozes privilegiadas nesses eventos foram aquelas veiculadas pelas parteiras, pajés e AISs. Nesse caso, como primeira constatação, pode-se dizer que, ao congregarem sob o mesmo rótulo uma multiplicidade de atores e nomeá-los parteiras, pajés e AISs, esses eventos comunicativos também contribuíram para reforçar a existência dessas posições nas aldeias indígenas da região e propiciar a emergência de tais categorias sociais no campo da saúde indígena, bem como dos sentidos atribuídos a esses praticantes e às suas práticas no cotidiano das comunidades indígenas.

Nesses encontros do Alto Juruá, a noção de parteira foi utilizada para se referir a um conjunto heterogêneo de mulheres com trajetórias particulares no que diz respeito às experiências de assistência à gestação e ao parto. Sob a noção genérica e universal de parteira, existem realidades diversas no que se referem aos cuidados indígenas prestados às gestantes e às parturientes. Dessa forma, a categoria parteira foi utilizada para classificar desde as mulheres que têm ampla experiência em "pegar menino" e são reconhecidas, ou não, pelo termo 'parteira', até as mulheres que não tinham experiência prática, mas foram indicadas pela 
comunidade e/ou suas lideranças para fazerem os cursos de parteiras e assumirem esse cargo. ${ }^{5}$

Para as antropólogas que atuaram na execução desses encontros, o amplo emprego da noção de parteira constitui um efeito das relações interétnicas estabelecidas entre os povos indígenas do Alto Juruá e a sociedade envolvente. Entretanto, os sentidos que essa noção assume, nos diferentes contextos étnicos e comunitários em que ela é utilizada, não necessariamente correspondem àquela que é vigente na sociedade não indígena (Instituto Olhar Etnográfico, 2006b).

Da mesma forma, o termo 'pajé' foi usado para denominar uma diversidade de especialistas com conhecimentos diferenciados acerca da manutenção da saúde e da cura de doenças, abarcando diferentes especialistas no interior de uma mesma etnia como entre os Huni Kuin, que distinguem os conhecedores dos "remédios da mata" (dauya, "aquele com remédio", que cura por meio do uso das plantas) e os que "trabalham com o espiritual" (mukaya, "aquele com amargo", que cura com a ajuda dos yuxin) (Lagrou, 2007); e pajés provenientes de diferentes etnias - Katukina, Kaxinawa, Ashaninka. Nos discursos durante as reuniões, essa categoria foi utilizada também para qualificar certas práticas de alguns AISs que disseram "trabalhar como pajé". Apesar de haver termos nativos para designar os diversos tipos de xamãs (Langdon, 1996) que atuam em cada um dos povos representados nesses eventos, eles não foram utilizados pelos participantes das reuniões.

Geralmente a função de pajé é desempenhada por homens, entretanto algumas mulheres mais velhas que estiveram presentes nos encontros também foram

consideradas, conhecedoras não apenas das técnicas relacionadas com o evento do parto, mas de práticas terapêuticas tradicionais, como o uso de ervas medicinais ou mesmo de técnicas xamânicas. Três das parteiras kaxinawa definiram-se, por exemplo, como dauya e këyuaki, termos que designam pessoas que praticam formas específicas de xamanismo. O primeiro termo faz referência (...) ao especialista em ervas medicinais, enquanto o segundo designa a pessoa que conhece o uso das rezas. (...) Igualmente, uma das mulheres shanënawa, reconhecida como parteira, é também tsibuya, termo conferido a um tipo de pajé (literalmente 'aquele que tem amargo'), que se caracteriza pela capacidade de incorporar espíritos que efetuam, por intermédio do corpo do xamã, a extração da doença através da sucção. (Instituto Olhar Etnográfico, 2006b: 89)

Assim, tanto a concepção de 'parteira' quanto a de 'pajé', utilizadas para nomear alguns dos participantes dessas reuniões, podem ser consideradas categorias emergentes, porque, além de serem forjadas nas relações interétnicas estabelecidas entre os povos indígenas e a sociedade nacional e o sistema mundial, constelam diferentes sentidos de acordo com o contexto discursivo em que são empregadas. ${ }^{6}$

Por sua vez, os AISs foram os únicos participantes das reuniões a ocuparem um cargo formal e remunerado instituído pelo Estado para prestarem serviços de 
atenção à saúde de suas comunidades. No entanto, mesmo diante das atribuições universais a eles delegadas pelo sistema oficial de saúde - o subsistema de Atenção à Saúde Indígena -, aqueles que participaram desses eventos comunicativos também apresentam trajetórias bastante heterogêneas, que ficaram evidenciadas quando os participantes falaram sobre as práticas que realizam ao exercerem o seu ofício. Além de pertencerem a diferentes etnias, o que faz com que esse cargo seja apropriado de maneira particular em cada contexto étnico-comunitário em que é criado, os AISs também se encontram em momentos distintos de formação.

No Acre, a formação de AIS foi iniciada em 1988 pela ONG Comissão PróÍndio/Acre. Essa capacitação estava baseada na prevenção e no saneamento. (...) Também entre 1990 e 1991 a ONG internacional Médicos sem Fronteiras realizou uma campanha que, entre outras atividades, incluiu a capacitação de indígenas em relação a algumas técnicas biomédicas. A Funai, na época em que estava encarregada pela atenção a saúde indígena, capacitou alguns índios como auxiliares de enfermagem. Quando a saúde indígena passa a ser responsabilidade da Funasa, foi assinado um convênio com a União de Nações Indígenas (UNI), onde esta assumia a responsabilidade pela atenção a saúde dos povos indígenas do Acre. Entre as competências da UNI estavam a de capacitar e contratar os AIS. Mas, segundo os depoimentos prestados nas Reuniões de Parteiras, Pajés e Agentes de Saúde, as capacitações foram deficitárias. Com o término do convênio, a responsabilidade pela capacitação dos AIS retornou para a Funasa. Até o período de realização do Projeto Acre, muitos AIS que estavam atuando nas comunidades indígenas não haviam concluído todos os módulos da capacitação e alguns deles não haviam recebido nenhum curso até o momento. (Instituto Olhar Etnográfico, 2006b: 28)

Esses fatores conjugados propiciaram a cada AIS reinventar a sua prática no cotidiano de atenção à saúde. Alguns realizam apenas os procedimentos preconizados pelo sistema oficial de saúde; outros, em seu atendimento, combinam as condutas e recursos dos brancos às práticas indígenas de autoatenção. Em relação a isso, os discursos proferidos durante as reuniões indicam que as comunidades indígenas do Alto Juruá se apropriaram do cargo de AIS de distintos modos, submetendo-o também ao processo de indigenização ao lhe atribuir diferentes papéis e distintos significados à sua atuação nos múltiplos contextos comunitários em que estão situados.

De fato, é preciso reconhecer que os povos indígenas no Alto Juruá se encontram em diálogo com os representantes e com os recursos do modelo médico hegemônico há algum tempo, apesar dessa interação ter sido intensificada a partir de 1999 com a implantação do subsistema de Atenção a Saúde Indígena. O processo histórico de contato interétnico, portanto, propiciou a emergência de organizações socioculturais intermédicas de promoção e cuidados com a saúde. Ao ser incorporada 
aos universos sociomédicos indígenas, a biomedicina foi indigenizada e colocada a serviço da reprodução sociocultural e econômica dos povos indígenas. Da mesma forma, como vai se tratar a seguir, os conhecimentos e as coisas do branco disponibilizados pelos cursos de aperfeiçoamento das parteiras tradicionais indígenas, ao serem apropriados pelos povos indígenas do Alto Juruá, contribuiram para a reconfiguração dos próprios sistemas indígenas locais de atenção ao parto.

\section{Notas}

1 Os povos indígenas contemplados pelo projeto foram: Kaxinawa, Katukina, Ashaninka, Shanenawa, Yawanawa, Kaxarari, Jaminawa, Jamamadi, Kamadeni, Kulina, Apurinã, Nawa, Poyanawa e Nukini.

2 No Acre, há duas grandes bacias hidrográficas: a do Juruá e seus afluentes e a do Purus (Instituto Olhar Etnográfico, 2006a). Os critérios utilizados para a escolha das aldeias que sediariam os eventos foram: facilidade de acesso, localização geográfica estratégica para a participação de indígenas; e estrutura física para hospedar os participantes e realizar os eventos.

3 Os falantes da língua pano contemplam $88 \%$ da população indígena da região. Entre eles, o povo kaxinawa é o mais numeroso, com aproximadamente quatro mil indivíduos, distribuídos em vinte TIs localizadas na região do Alto Juruá (Instituto Olhar Etnográfico, 2006b: 7).

4 O cupishawa, estrutura circular, geralmente sem paredes e com teto cônico de palha, é usado para realizar festas, reuniões comunitárias ou outros tipos de eventos públicos (Instituto Olhar Etnográfico, 2006a).

5 Sobre os cuidados que se deve ter com o termo 'parteira', em razão do fato de ele homogeneizar diferentes agentes que se dedicam à assistência ao parto, ver também Tornquist (2004: 98).

6 Um trabalho que demonstra o quanto a figura do pajé é produto do contato interétnico é o elaborado por Conklin (2002), que trata da importância dos xamãs nas esferas nacionais e internacionais do movimento ambientalista, quando assume o status de "guardião natural da natureza". 


\section{Cursos, Partos e Parteiras Tradicionais: apropriações indígenas dos conhecimentos e das coisas do branco}

O primeiro tópico da programação dos encontros entre parteiras, pajés e agentes indígenas de saúde (AISs), como já foi visto, consistiu na avaliação dos cursos de aperfeiçoamento das parteiras tradicionais indígenas que aconteceram no estado do Acre entre 2000 e 2004. Os enunciados veiculados durante eventos do Alto Juruá revelaram o quanto esses cursos foram apropriados e indigenizados pelos povos indígenas da região. A avaliação positiva e a demanda pela realização de outros cursos expressam o desejo desses povos de terem acesso aos conhecimentos e às coisas provenientes do mundo dos nawa (brancos), nesse caso, aos materiais do kit parteira.

No entanto, antes de passar às vozes indígenas, convém trazer algumas informações sobre esses cursos de aperfeiçoamento, de forma que contribuam para a compreensão dos sentidos que informaram as falas indígenas proferidas nos encontros do Alto Juruá. Sua retomada se torna importante não só pelo fato de terem sido colocados em pauta nas reuniões de parteiras, pajés e AISs, mas também por serem os antecedentes diretos dos eventos comunicativos que constituiram o contexto de emergência dos discursos indígenas aqui analisados. Além disso, os cursos remetem ao processo de irrupção das políticas públicas em localidades específicas e às dinâmicas de apropriação e indigenização dessas políticas pelos povos indígenas, que levam à instituição de novos locais de cultura.

\section{Cursos de aperfeiçoamento de parteiras indígenas}

Algumas lideranças do movimento de mulheres indígenas do Acre realizaram, entre 2000 e 2004, cinco cursos de aperfeiçoamento de parteira indígenas financiados pelo Projeto Médico Internacional da Federação das Parteiras da Alemanha. Esses cursos, que tiveram duração média de quatro dias cada um, envolveram 163 parteiras indígenas dos Yawanawa, Kaxinawa, Shanenawa, Arara, Katukina, Poyanawa, Nawa, Nukini, Jaminawa-Arara, Kulina, Ashaninka e Apurinã, e acon- 
teceram em quatro municípios do estado do Acre - Tarauacá, Jordão, Santa Rosa, Marechal Thaumaturgo e Mâncio Lima - e um no sul do Amazonas, em Pauini, realizados em espaços cedidos pelo poder público local ou por organizações religiosas que atuam no local (GMI, 2004a, 2004b).

De acordo com as lideranças do movimento de mulheres indígenas, os cursos, ao ensinarem as parteiras a manipular determinados instrumentos - tais como a tesoura, por exemplo - e ao introduzirem algumas noções de higiene em sua prática, podem contribuir para aperfeiçoar sua atuação. Além de terem acesso a um conjunto de conhecimentos, as participantes dos cursos ganharam um kit com materiais básicos para as parteiras: tesoura, linha esterilizada, lanterna, luvas, escova para lavar as mãos, fita métrica, sabonete, saboneteira, toalha, álcool iodado, gases, algodão, avental, pinard (estetoscópio de madeira), guarda-chuva, botas e bolsas (GMI, 2004b). No kit, estava incluído ainda o Livro da Parteira (Brasil, 2000), as fichas para notificação dos eventos de parto assistidos nas aldeias e um certificado de participação, muito valorizado pelas participantes. Assim, os conhecimentos advindos do mundo dos brancos se somariam aos saberes tradicionais indígenas, aprimorando a assistência aos partos domiciliares e contribuindo para a redução da mortalidade materna e infantil indígena.

No entanto, as lideranças do movimento também viam nos cursos de aperfeiçoamento uma estratégia de luta pelo reconhecimento profissional das parteiras e, consequentemente, a sua contratação remunerada. "As exigências das parteiras são no sentido da continuação deste trabalho, fornecimento do kit básico e, principalmente, do reconhecimento destas pelo poder público como profissional que são" (GMI, 2004b: 2).

A programação dos cursos de aperfeiçoamento de parteiras indígenas foi organizada de acordo com o conteúdo veiculado pelo Livro da Parteira (Brasil, 2000), que, elaborado pela organização não governamental (ONG) Curumim em parceria com o Ministério da Saúde (MS), disponibiliza alguns conhecimentos biomédicos básicos sobre os processos fisiológicos e anatômicos relacionados à gestação e ao parto, bem como fornece orientações sobre procedimentos de higiene e manipulação dos materiais do kit parteira. Entre as questões abordadas no curso estão: perfil da parteira e da gestante; corpo da mulher (ovulação, menstruação e gravidez); exames que podem ser feitos pelas parteiras; trabalho de parto e posições do parto; cuidado com os recém-nascidos (limpeza e forma de cortar o umbigo); material para um parto limpo (procedimentos de esterilização); experiências de parto em domicílio; problemas na gravidez, no parto, no pós-parto e com o recém-nascido; plantas medicinais; e avaliação (Brasil, 2000).

Na perspectiva assumida no Livro da Parteira (Brasil, 2000), as parteiras tradicionais são vistas como agentes que apresentam, sobre o corpo feminino, um conhecimento que necessita de aperfeiçoamento. Ao intercalar desenhos e texto, o livro descreve os órgãos externos e internos do aparelho reprodutor feminino - 
útero, trompas, ovário, vagina -, bem como o processo de desenvolvimento do feto durante a gestação.

É importante conhecermos melhor a genitália. Na parte de fora, vemos os pelos pubianos, os grandes e pequenos lábios, o clitóris, a entrada da uretra (por onde sai a urina) e logo abaixo a entrada da vagina (por onde sai o sangue da menstruação, por onde o pênis do homem entra numa relação sexual e por onde sai o bebê). A parte que vai da abertura da vagina até o ânus, chamamos de períneo. O períneo estica muito na passagem da cabeça do bebê. (Brasil, 2000: 14)

No livro, enfatiza-se ainda a importância de as gestantes fazerem as consultas pré-natais, e se indicam os procedimentos que podem ser feitos pelas parteiras ao acompanharem uma gravidez: observar os olhos da grávida (quando estiverem brancos é sinal de anemia); examinar o pulso, a urina e a temperatura; auscultar o coração do bebê com o pinard; examinar a barriga. E se apresentam também instruções sobre a forma de identificar riscos e de agir em casos de complicações durante a gestação e o parto, recomendando que, nesses casos, as mulheres devem ser imediatamente encaminhadas para os serviços de saúde.

Os cursos organizados pelas lideranças indígenas foram ministrados em português por uma técnica de enfermagem não indígena, embora muitas participantes tivessem domínio apenas da língua indígena. Geralmente, os cursos eram abertos com a apresentação dos participantes. Em seguida, as lideranças de mulheres indígenas expunham os objetivos da atividade, esclarecendo que os cursos não visavam a capacitar, mas a aperfeiçoar o trabalho que as parteiras já realizavam em suas aldeias. Por sua vez, a técnica de enfermagem chamava atenção para a necessidade de as parteiras se esforçarem para apreender o conteúdo do curso, já que muitas delas não compreendiam nem falavam português (GMI, 2004b).

Para repassar os conteúdos técnicos às parteiras, foram utilizados vários recursos didático-pedagógicos: trabalho em grupo e apresentação de cartazes; aulas expositivas; desenhos em cartolina do corpo feminino; apresentação de vídeos; identificação das plantas medicinais utilizadas na gestação e no parto; realização de dinâmicas. "Para melhor assimilar o que estavam estudando, foi realizada esta dinâmica: as pessoas formaram um círculo, usaram como instrumento uma camisinha, encheram de ar e, jogando uma para a outra, fizeram sua avaliação" (GMI, 2004b: 27).

\section{Antecedentes dos cursos}

Tanto as lideranças do movimento de mulheres indígenas quanto a técnica de enfermagem que ministrou os conteúdos técnicos nos cursos de aperfeiçoamento das parteiras tradicionais indígenas adquiriram habilidades ao participarem das 
capacitações de parteiras tradicionais realizadas pela ONG Curumim ${ }^{1}$ em pareceria com o MS, entre 2000 e 2003 no município de Rio Branco, estado do Acre. ${ }^{2}$

De fato, os primeiros programas e cursos de capacitação de parteiras tradicionais estavam destinados às parteiras não indígenas. A inclusão das mulheres indígenas veio a reboque. A esse respeito, não parece ter havido uma reflexão sobre o fato das sociedades indígenas possuírem particularidades culturais em relação às populações rurais não indígenas. A aplicação das mesmas políticas e iniciativas implica assumir, já de início, que a assistência ao parto nas comunidades indígenas é similar ao sistema de parto da população rural acreana; que as necessidades em ambos os casos são as mesmas e que, portanto, as soluções o devem ser também. (Instituto Olhar Etnográfico, 2006b: 96)

As ações de capacitação realizadas em Rio Branco fazem parte do Programa de Capacitação de Parteiras Tradicionais do MS, que teve início em 1991 (Tornquist, 2004). Esse programa, por sua vez, está alinhado às diretrizes postuladas pela Organização Mundial da Saúde (OMS) para a humanização do parto em países em desenvolvimento. Tais diretrizes reconhecem as parteiras como mulheres leigas que, por terem entendimento sobre partos, devem ser incorporadas à equipe de saúde como doulas ou prestadoras de serviços de encaminhamentos, desde que recebam treinamento para a execução de suas tarefas. "É assim que essas parteiras são vistas e descritas pela OMS, e é a partir desta concepção - seu 'não saber' ou seu 'saberes' não modernos - que se argumenta a necessidade de ofertar os cursos de capacitação de parteiras leigas ou tradicionais" (Tornquist, 2004: 217, grifos do original).

Portanto, essas ações integram uma política pública desenvolvida pelo Estado brasileiro que está em consonância com as recomendações da OMS e, ao serem apropriadas e indigenizadas pelo movimento de mulheres indígenas do Acre, tiveram seus desdobramentos entre os povos indígenas dessa região. A partir de então, as lideranças indígenas que propuseram a continuidade dessas ações de capacitação junto às parteiras indígenas, passaram a reproduzir a "metodologia curumim de capacitação" (Tornquist, 2004) por meio da realização dos cursos de aperfeiçoamento por elas ministrados.

Por outro lado, tanto os cursos de aperfeiçoamento das parteiras indígenas quanto os de capacitação das parteiras tradicionais fazem parte do processo histórico iniciado no começo do século XIX que transformou a assistência ao parto no Brasil. Naquele momento, sob a influência dos médicos higienistas engajados no projeto de construção de civilidade, criaram-se cursos de formação para as parteiras leigas, os quais foram responsáveis pela passagem do ofício de parteira para a profissionalização da assistência ao parto. "Neste processo de mudanças, foram deslocados os saberes femininos, leigos e especializados, subalternizando 
as mulheres que prestavam assistência: parteiras, comadres, matronas e curiosas" (Tornquist, 2004: 78). ${ }^{3}$

Ao profissionalizar a assistência ao parto, os cursos realizados desde o início do século XIX constituíram dispositivos de medicalização do oficio das parteiras e da arte de partejar, transferindo a responsabilidade da atenção prestada às gestantes e parturientes para os médicos. Se a história, assim, produz testemunho, talvez seja importante se perguntar se os cursos realizados no Acre, sejam os de aperfeiçoamento, sejam os de capacitação de parteiras, não estariam contribuindo também para a medicalização dos sistemas comunitários de atenção ao parto, vigentes nas comunidades indígenas dessa região.

\section{A avaliação indígena dos cursos de aperfeiçoamento}

De modo geral, as participantes das reuniões de parteiras, pajés e AISs que fizeram os cursos de aperfeiçoamento das parteiras tradicionais indígenas os consideraram uma boa experiência, principalmente pelos conhecimentos apreendidos e pelos kits recebidos. "Rapaz, pra mim foi bom porque eu aprendi o que eu não sabia ainda! Eu 'pegava menino', mas não sabia dos pontos que hoje em dia já sei, mais ou menos um pouco!" (Parteira jaminawa-arara).

Dos conhecimentos apreendidos nos cursos, os mais valorizados pelos participantes foram os relativos aos procedimentos de higiene e ao manuseio dos materiais do kit. Durante os encontros, frequentemente foi enfatizado que, antes dos cursos, as pessoas que assistiam os partos não "tinham asseio" e, depois, passaram a adotar medidas como cortar as unhas e lavar as mãos, de modo a prevenir que certas doenças acometessem a mãe ou o recém-nascido. Da mesma forma, os conhecimentos sobre o uso do pinard para auscultar o coração do feto, das luvas para "aparar menino" ou mesmo da esterilização da tesoura para cortar o cordão umbilical do bebê, entre outros, foram considerados importantes por terem contribuído para a melhoria da qualidade da assistência ao parto prestada pelas parteiras indígenas.

Olha, o que eu percebi do conhecimento branco e do conhecimento tradicional, é que, de primeiro, as parteiras não tinham escutado o trabalho dos brancos sobre como pode fazer um parto. É por isso que antes, às vezes, a parteira quando pegava neném não lavava nem as mãos. De primeiro a gente não tinha tesoura. Não tinha nada, né? O papai sempre fala que quando a mulher ganhava neném cortava com a faca de taboca que não era esterilizada: cortava e guardava. Aí, quando nascia outro menino, com a mesma faca cortava de novo. De primeiro, não morria assim tanta criança, mas às vezes morria de tétano. Depois que a parteira teve esse conhecimento de higiene eu percebi que melhorou bastante. (AIS katukina) 
Durante o encontro na aldeia de Campinas, as parteiras nawa, nukini e arara também procuraram demonstrar o quanto haviam incorporado em sua prática os conhecimentos aprendidos durante os cursos. A maioria afirmou que, para acompanhar as gestantes de suas comunidades, faziam visitas domiciliares para interrogá-las sobre o seu estado de saúde. Nessas ocasiões, utilizavam os materiais do kit parteira para medir a barriga da gestante e auscultar o coração do feto, assim como realizavam alguns exames físicos para verificar se a mulher apresentava indícios de desnutrição ou anemia.

No entanto, alguns participantes dos encontros falaram que há parteiras que encontram dificuldades para aprender os conhecimentos transmitidos durante os cursos por não saberem ler nem escrever e tampouco terem domínio do português. Essa limitação restringiria a capacidade de compreensão dos conhecimentos relativos ao manuseio correto dos materiais do kit conforme ensinado durante os cursos.

Vamos supor: algumas parteiras, não todas, receberam o material, mas não têm conhecimento de usá-lo de acordo com a capacitação. Por quê? Muitas parteiras têm prática, mas têm dificuldades teóricas: não escreve e não lê. Várias têm um Livro da Parteira, mas coitada, não sabe lê e fica em segredo sempre. Na hora de trabalhar, elas têm essa dificuldade. (AIS kaxinawa)

Entre os povos pano, o fato de não dominarem o português, idioma em que são ministrados os cursos, e tampouco ler e escrever não faz com que as parteiras deixem de participar desses eventos quando têm oportunidade. Segundo os participantes dos encontros, quando a parteira não sabe ler e participa do curso, ela "pega" os conhecimentos de cabeça e os guarda em sua memória, ao lado dos outros saberes que detém. Quando surge a necessidade, os coloca em prática de acordo com aquilo que ela estiver pensando. Porém, as mulheres ashaninka da região de Tarauacá, segundo depoimento do único presente dessa etnia, recusaram-se a participar do encontro, inicialmente apreendido pelos povos da região como mais um curso de capacitação de parteiras, justamente por não se comunicarem em português, nem saberem ler e escrever.

Dentre os itens mais bem avaliados dos cursos de parteiras, está a distribuição dos kits parteira. "O fato de o material ser o ponto central das considerações dos participantes leva a pensar que seja esse o aspecto mais significativo para as mulheres e o que teve mais impacto em suas práticas" (Instituto Olhar Etnográfico, 2006b: 97).

O material do kit facilitou pras pessoas que talvez não tivessem uma tesoura disponível pra [cortar o cordão umbilical]. Com a mesma tesoura cortava os panos e outras coisas. Hoje em dia não! Já tem tesoura própria pra usar naquele trabalho. Aí ninguém arrisca a perder seu filho por cortar errado. É uma coisa 
mais profissional que as parteiras têm hoje. (...) As parteiras têm que estar mais técnicas nessas áreas aí principais. (AIS kaxinawa)

As mulheres katukina que participaram da reunião de Campinas, por sua vez, agregaram elementos importantes ao avaliarem os kits, considerados "coisas de parteira nawa" (branca), em contraposição às práticas indígenas de assistência ao parto definidas como "da nossa cultura":

Eu nunca uso essas coisas de parteira nawa. Eu não tenho nada: tesoura, álcool, fralda... Nem balança nós tem. Primeira vez que eu participo de curso. (...) Eu quero começar agora. Eu trabalhava assim na nossa cultura mesmo e nunca usei essas coisas. Tudo o que ela falou nós também precisa. (Parteira katukina)

Contudo, outras mulheres katukina já haviam participado dos cursos. Uma delas, que há dez anos "pega criança", diz que, depois de ter feito o curso, passou a usar a tesoura para cortar o cordão umbilical, deixando de fazê-lo com faca de taboca como era o costume anteriormente. Outra afirma que, depois do curso, deixou de "pegar menino" da forma tradicional e passou a usar luvas e a esterilizar a tesoura como fazem os brancos.

Nem sempre, entretanto, o destino de alguns dos materiais do kit é o preconizado durante os cursos de parteiras. Algumas mulheres disseram ceder as luvas ou outros materiais do kit ao AIS da sua comunidade. Outras expressaram o seu incômodo em adotar alguns dos procedimentos ensinados durante os cursos, como no caso das luvas. "Antigamente não tinha luva e até agora a gente (...) pega sem luvas porque a gente acha melhor: a mão não fica lisa e não tem perigo de derrubar o bebê. Então a tradição é assim!" (Parteira jaminawa). Além disso, nem sempre os materiais mais valorizados são os destinados ao acompanhamento da gestante e à assistência ao parto propriamente dito, mas os que melhoram as condições de trabalho das parteiras, tais como a lanterna e o guarda-chuva!

Ainda assim as falas dos indígenas durante as reuniões revelam que os materiais do branco utilizados nos cuidados com a gestação e o parto são desejados sim, porém nem sempre estão disponíveis. Diante disso, o kit parteira foi enfaticamente reivindicado pelas mulheres que participaram dos encontros no Alto Juruá tanto no que dizia respeito à reposição dos materiais que acabaram e/ou estragaram quanto à distribuição de kits para aquelas que ainda não haviam sido contempladas.

As mulheres katukina que participaram do evento de Campinas e que não haviam recebido o kit alegaram necessitar desses materiais para trabalhar, por estarem vivendo na lei do branco. "Antigamente não existia esse material de parteira. Mas, já que nós estamos na lei do branco, ela quer esse material, no caso: tesoura, lanterna, luva, bota, gaze, iodo e bacia pra dar banho na criança e na mãe. Pra ela, esse material é importante" (AIS traduz fala da parteira). 


\section{O parto entre os Pano e as mudanças na prática do 'pegar menino'}

Ao analisar os discursos proferidos durante os encontros entre parteiras, pajés e AISs, percebe-se que o evento de parto faz parte de um processo que abarca desde a gestação até o "período pós-parto, que pode ser mais ou menos longo, dependendo do caso. Durante essas etapas, os genitores, especialmente a mãe, devem observar diversos cuidados destinados à preservação da saúde da criança e da mulher" (Instituto Olhar Etnográfico, 2006b: 73).

Na caracterização dos sistemas de parto apresentada pelo Instituto Olhar Etnográfico (2006b), o evento de parto entre os povos indígenas do Alto Juruá não interrompe a rotina familiar, nem mobiliza recursos especiais de assistência, a não ser quando ocorrem complicações. A mulher pode dar à luz sozinha ou auxiliada por outras mulheres mais experientes. O papel dessas mulheres que ajudam, "em muitos casos, é mais social - o ato de receber a criança ou de cortar o umbigo gera uma relação especial entre a criança e a pessoa que faz o parto, por exemplo - do que profissional" (Instituto Olhar Etnográfico, 2006b: 47).

Geralmente, na bibliografia sobre os povos indígenas que participaram nos encontros do Alto Juruá, encontram-se informações acerca dos cuidados observados durante a gestação e o pós-parto, mas não tratam dos eventos de partos propriamente ditos (Instituto Olhar Etnográfico, 2006b). Todavia, alguns estudos realizados com os Kaxinawa apresentam dados importantes sobre o nascimento que, em virtude da possível unidade cultural existente entre os povos pano (Erikson, 1992; Santos-Granero G Barclay, 1998), podem ser utilizados para pensar o parto nas outras etnias pertencentes a essa mesma família linguística.

Entre os Kaxinawa, tradicionalmente, o parto ocorre sob o mosquiteiro na casa da parturiente. No momento do parto, a mulher é auxiliada por sua mãe e por outros parentes próximos.

O marido tem um papel fundamental, já que permanece atrás dela, segurando-a por baixo dos braços. Nenhum outro homem pode ver os genitais ou o sangue da mulher, já que ela ficaria com muita vergonha e ele sem sorte na caça. A placenta é disposta fora da aldeia. Após o parto, se esquenta água e se lavam a mulher e a criança, que ficam na rede por vários dias, fora da vista dos outros. (...) Só depois de cinco dias, a mulher saía da rede e se pintava com jenipapo para não ter febre, da mesma forma que a criança e o marido. (McCallum apud Instituto Olhar Etnográfico, 2006b: 46)

Lagrou (2007), no livro A Fluidez da Forma: arte, alteridade e agência em uma sociedade amazônica, descreve um parto kaxinawa de que teve oportunidade de participar. Segundo a autora, a mulher huni kuin que está parindo recebe au- 
xílio dos seus parentes mais próximos. Cabe aos homens vinculados à parturiente por laços de parentesco - esposo, pai ou irmão - ajudar a segurá-la no momento do parto, sustentando-a pelas axilas. Enquanto isso, as mulheres - avós, mães, irmãs - cantam e aplicam banhos medicinais na mulher que está dando à luz, de modo a propiciar um bom parto, bem como criar condições para a recuperação da mãe e para o crescimento adequado do recém-nascido. Durante o trabalho de parto acompanhado por Lagrou (2007), as mulheres massageavam as costas e a barriga da parturiente com uma infusão morna feita à base de plantas.

A pessoa que apara a criança ao nascer, geralmente, é responsável também por cortar o seu cordão umbilical. Os Kaxinawa usam, para isso, uma lâmina de bambu ou, quando esta não está disponível, outro instrumento cortante. Depois de seco, o cordão umbilical é enrolado ao arco do pai tendo em vista trazer-lhe boa sorte na caça. "A primeira caçada depois do nascimento da criança será, então, com o arco protegido pelo cordáo umbilical seco (antes disso o pai não pode caçar)" (Lagrou, 2007: 306). A placenta, por sua vez, é imediatamente levada para a floresta ou enterrada perto de uma nascente, já que garantiria um coração forte para a criança.

Logo após o nascimento, o recém-nascido é modelado por um adulto, escolhido por seus pais, a quem caberá "dar o seu corpo à criança" (Lagrou, 2007). Feito isso, o bebê é posto na rede, junto com a sua mãe, resguardado pelo mosquiteiro. Na manhã do outro dia, a criança recebe um banho medicinal e é pintada com urucum. A mãe também é banhada a fim de estancar seu sangramento. Após secar o umbigo, a mãe e a criança podem sair do mosquiteiro. Nesse momento, um parente próximo, considerado bom trabalhador e cheio de conhecimento, para proteger a criança dos maus espíritos (yuxin), pintará a cabeça do recém-nascido com jenipapo entoando um canto ritual.

Acredita-se que as mãos, o suor e as palavras usadas no ritual passam o caráter, o poder, o dau (encantamento, medicamento) e o dua (brilho, saúde e sorte) para a pessoa que os recebe. A fala ritual, o sopro e o toque passam os pensamentos (xina) e o conhecimento (una) para aquele que recebe as encantações. Dessa forma, não somente o corpo, mas os primeiros pensamentos da pessoa são, simultaneamente, modelados. O corpo não é percebido como uma entidade independente, separada de outros corpos. Sua forma e estado são resultado e uma modelagem e fabricação coletiva, e é uma preocupação dos parentes próximos. (Lagrou, 2007: 305)

Esses dados são relevantes por auxiliarem a compreensão da categoria "parto tradicional" realizado nas aldeias antes do advento dos cursos de aprimoramento das parteiras tradicionais indígenas, ao mesmo tempo que demonstra o quanto a mobilização dos parentes próximos da parturiente para auxiliá-la no momento de dar à luz é fundamental para seu sucesso. Além disso, nesses dados também se observa a importância das práticas usadas no parto não só para a manutenção da 
saúde da mulher e do recém-nascido, mas, principalmente, para o forjamento da pessoa indígena.

Durante os encontros do Alto Juruá, os participantes empregaram a noção "pegar menino" para se referir ao ato de partejar. Essa expressão demonstra que antes de fazer o parto, a função de quem auxilia a mulher a dar à luz é "aparar" a criança e contribuir para modelar o novo ser que está nascendo, estabelecendo com ele um vínculo social determinado. Ao que tudo indica, o ato de parir requer um conhecimento inscrito em seus corpos que, por sua vez, é apreendido por meio da prática. Assim, as lembranças das experiências de parto acessadas na fala dos indígenas são conhecimentos inscritos no corpo, suporte sobre o qual se desenvolvem os saberes sobre o gestar e o parir.

\section{As mudanças na prática indígena do 'pegar menino'}

Os indígenas que estiveram presentes nos encontros do Alto Juruá empregaram o dispositivo discursivo da comparação para falar sobre as mudanças que a prática do "pegar menino" sofreu após o advento dos cursos de parteiras que aconteceram na região, contrastando a forma como eram realizados os partos anteriormente e como eles são feitos após a ministração dos cursos. De acordo com os depoimentos, a incorporação dos materiais do kit na prática do "pegar menino" foi um dos fatores que contribuíram para transformar o "parto tradicional".

Ela aprendeu a fazer parto com a mãe dela. Aprendeu fazendo parto, quando era pequena. Antes do curso ela já fazia parto. Quando elas receberam esse curso de aperfeiçoamento, mudou algumas coisas. Agora elas não tão mais utilizando muito como era o parto tradicional. Antes elas não tinham aquelas lonas pra tá pegando as crianças. Forrava com o couro de veado ou de outros animais pra tá pegando a criança que ia nascer. (...) E cortava com qualquer coisa que tinha: faca, terçado. Hoje tem a tesoura que ela ferve, pra ser utilizada para cortar o cordão umbilical da criança. E hoje ela já tem o pano. Às vezes a mãe dela questiona sobre como o parto tá sendo feito agora, porque tá muito diferente. Antes não era assim! Quando a mãe dela a acompanha, ela pede pra mãe lavar a mão e escovar os dedos, porque ela recebeu uma escova no kit. Então, a mãe briga com ela, porque antes não precisava escovar os dedos pra tá pegando a criança e não tinha nenhum problema. (AIS traduz a fala da parteira kaxinawa)

Os cursos de parteiras também incentivaram a ocorrência de mudanças na organização familiar da assistência prestada às parturientes. Segundo um agente de saúde kaxinawa, tradicionalmente a mulher que estava parindo recebia ajuda de um grupo de mulheres vinculadas a ela por laços de parentesco. Durante os cursos, as parteiras foram orientadas a, quando assistirem um parto, serem acompanhadas 
somente por uma ajudante, para não que não se exponha a intimidade da parturiente à curiosidade e aos comentários daquelas que estiveram presentes no momento do parto. Essa recomendação é veiculada pelos cursos como uma questão de ordem ética que deve ser observada pela parteira em sua prática. Assim, observam-se os valores da privacidade e da intimidade, bem como a necessidade de que os princípios éticos cultivados no modelo médico hegemônico sejam reproduzidos nos discursos dos participantes das reuniões e se sobreponham às formas tradicionais de cuidados utilizados nos eventos indígenas de parto.

Eu participei do curso das mulheres, da parteira. (...) Do que eu tô lembrado, as mulheres deram muita orientação pras parteiras de como deviam cuidar as grávidas. (...) Agora, por quê? Quando a mulher tava sofrendo, de primeiro, no meu conhecimento, trazia três, quatro mulheres pra cuidar daquela paciente. Mas, desde aquele curso pra cá se recomendou que é pra ir só a parteira e a acompanhante. Porque muitas vezes aquelas que vão participar do parto podem falar da mulher, né? Então pra não acontecer isso, foi orientado que tem que ir só a parteira e a outra pra cuidar. (AIS kaxinawa)

De qualquer forma, mesmo diante de algumas falas que reproduziram os valores biomédicos relacionados à assistência aos partos, os participantes dos encontros continuamente reafirmaram os aspectos positivos de parir na aldeia, até mesmo, em razão do fato de a mulher permanecer em sua casa, onde pode observar as dietas alimentares adequadamente, usar os remédios tradicionais para ter um parto normal, recuperar-se rapidamente após dar à luz, garantir a saúde do recémnascido e, receber os cuidados de seus familiares e parentes próximos.

No entendimento kaxinawa, o parto normal é aquele que ocorre rapidamente e não causa sofrimento à parturiente. Já aquele em que a mulher tem um trabalho de parto longo e sente muita dor é considerado um "parto perigo".

Já fiz o parto também só eu e Deus, porque a parteira não tava em casa. Eu não tinha porque gritar. Aí me socorri só com Deus mesmo que tava com nós! Porque Deus é só um, se a parteiro tá em casa ou não. A criança já tá grande! Tá aqui ela, é essa aqui de blusa amarela. Foi só eu e Deus mesmo no parto dela em casa. (...) Às vezes a gente tá ganhando parto normal, sem precisar de ninguém. É muito bom, né?! Agora tem muitas mulheres que tem o parto perigo também. Tem delas que é rápido e não dá trabalho a ninguém. Tudo isso já alcancei. (Mulher kaxinawa)

Algumas parteiras conhecem técnicas para intervir nos casos de perigo. Uma parteira jaminawa-arara diz posicionar com rezas a criança para nascer, se ela estiver sentada ou atravessada no momento do parto.

A grávida fica com os pés pra cima na rede e de cabeça pra baixo. Aí eu vou ajeitar o bebezinho dela com reza. Vou rezando e vou ajeitando, vou ajeitando, 
vou ajeitando. Vou rezando, vou rezando... Até que o neném vira (...) e fique numa posição normal. Aí você pode olhar que a cabeça tá certinha, o pezinho tá pra cima e ele tá normalzinho. Pra gente poder ajeitar neném tem reza que a gente reza! A gente tá rezando e tá ajeitando, tá rezando e tá ajeitando, tá rezando e tá ajeitando, tá rezando e tá ajeitando. Até quando chega normal.

Os discursos proferidos durante esses eventos comunicativos revelam que os cursos de parteiras se tornaram um divisor de águas na forma como antes os partos eram feitos e como eles têm sido realizados após os cursos nos múltiplos contextos étnicos e comunitários do Alto Juruá. Todavia, os discursos revelam que as mulheres não deixaram de operar com os saberes e as práticas indígenas de "pegar menino". Mesmo assim, parece que as relações interétnicas estabelecidas com os nawa nesses cursos têm sido decisivas para a configuração dos nascimentos indígenas nessa região.

\section{Os cursos e a emergência da parteira tradicional indígena}

Se a introdução dos procedimentos de higiene e dos materiais do kit parteira na prática do "pegar menino" foram indicadas como fatores que alteraram a forma de assistência ao parto, a modificação mais radical apontada nas falas dos indígenas durante os encontros foi o surgimento da parteira como alguém habilitado pelos cursos para acompanhar as gestações e assistir os partos nas comunidades dessa região. Do ponto de vista de uma jovem kaxinawa, a principal mudança foi o fato de as pessoas da sua comunidade não chamarem mais qualquer um para "pegar menino".

A maioria colocou sobre o kit. Esse kit foi bom mesmo pra todo mundo porque ajudou. Então, foi muita bom que veio, porque agora também a gente tá fazendo higiene. Não é qualquer um que chega pra pegar filho da gente. Já tem aquela parteira que fez o curso que a gente chama, convida e vai lá.

Entretanto, o processo de emergência da parteira tradicional não ocorre da mesma forma entre todos os povos indígenas do Alto Juruá. Na verdade, a noção de parteira, que aparece nos discursos como uma figura genérica e universal, encobre uma realidade extremamente diversa e dinâmica no que diz respeito aos processos de surgimento dessa personagem nas comunidades indígenas da região e às formas assumidas pela organização da assistência ao parto.

Segundo os dados que aparecem em etnografias que descrevem as sociedades indígenas, num passado recente, o parto era um evento que não necessariamente implicava a intervenção de um especialista. A ajuda, quando necessária, provinha 
do meio familiar mais próximo. Em muitos casos, a mulher dava à luz sozinha na floresta ou, simplesmente, contava com a ajuda de alguma parenta mais velha e de mais experiência, como a mãe ou a avó. Esta característica se vê refletida em certos aspectos do sistema de parto indígena atual, mesmo que atualmente o conceito de 'parteira' seja usado corriqueiramente entre algumas populações indígenas. (Instituto Olhar Etnográfico, 2006b: 50)

É justamente no contexto familiar, no qual as redes de parentesco são mobilizadas para auxiliar aquelas que estão dando à luz, que as mulheres hoje denominadas parteiras foram iniciadas na prática do "pegar menino". Se algumas delas, como as Katukina, aprenderam a "pegar menino" com a sua mãe, e outras foram introduzidas no ofício acompanhando as suas sogras, como as Nukini, a maioria das parteiras que participou dos encontros iniciou a "pegar menino" ainda jovem em situações onde não havia ninguém mais preparado por perto para auxiliar a mulher que entrava em trabalho de parto. Nessas ocasiões, elas eram orientadas pelas próprias parturientes, a quem estavam ajudando, ou mesmo aprenderam sozinhas, agindo de acordo com a "própria memória".

Porém, o aprendizado também pode ocorrer de forma diferente. Um AIS kaxinawa conta que as mulheres huni kuin aprendem a fazer partos no momento mesmo em que estão parindo, quando prestam atenção no que a pessoa que está ajudando faz para "pegar a criança". Assim, aprender a partejar e aprender a parir faz parte de um mesmo processo de aprendizagem - ambos os saberes são inscritos nos corpos por meio de experiências práticas. De qualquer forma, cabe à gestante decidir a quem recorrer para ajudá-la a parir ou optar por dar à luz sozinha.

O aprendizado das mulheres, no meu conhecimento, acontece na hora do parto, quando ela tá despachando. Ali [aquela que tá parindo] tá adquirindo experiência da pessoa que tá lá pegando, [aprendendo] como é que ela faz. Então, o conhecimento vem do ensino dos pais. Dos pais não quer dizer pai e mãe só, mas dos tios e dos próprios parentes perto. (...) Minha avó era acostumada a fazer o serviço, aí chamavam ela. A pessoa que pela primeira vez estava despachando, com certeza tava prestando atenção e aprendia. A pessoa até ficava curioso como é que pega. Aí já tem um pouco de experiência. Aí no caso se não tivesse aquela pessoa que pega, ela já pegava e com aquilo já praticava. (...) Tem mulher que não precisa de parteira, ela prefere ganhar só: 'só eu e eu mesmo!' Estas não precisam de parteira. Mas tem outras que já preferem, porque se der alguma coisa, a pessoa tá perto. (...) Então, o aprendizado das mulheres é mais ou menos esse: na hora do parto que a profissional [parteira] tá pegando, [a mulher] tá vendo. Se a parteira não tiver aí, a pessoa já pode assumir. (AIS kaxinawa)

No decorrer dos encontros entre parteiras, pajés e AISs, os Katukina relataram que antes dos cursos "qualquer pessoa" poderia "pegar criança". Quando ocorriam complicações durante a gestação ou no parto, o pajé era chamado para 
intervir. Segundo um pajé katukina, o seu povo começou a falar em parteira quando começou a estudar as "leis do branco":

Antigamente não existia parteira! Porque a gente, na nossa cultura mesmo, era assim: a filha ganhava neném, a mãe pegava; se for a irmã, o irmão dela mesmo pegava o neném. Não tem própria parteira! Antigamente, como se diz, qualquer um pegava o neném dos parentes. Hoje não! Hoje vocês começaram a estudar as leis do nawa e já começam a falar de parteira. Antigamente, não existia parteira própria pra pegar o neném! Quem trabalhava com a mulherada era o pajé! O pajé curava várias mulheres que ganhavam neném. (...) Hoje vocês estão estudando muito o negócio dos nawa, por isso tão falando de parteira, como aquela pessoa própria pra pegar o neném nas comunidades. Mas antigamente não existia isso.

Entre os Katukina, o parto é realizado na casa da gestante e o parente que estiver por perto será aquele que pegará a criança e cortará o cordão umbilical. Assim, "todas as mulheres, em algum momento de suas vidas, ajudavam a fazer um parto" (Instituto Olhar Etnográfico, 2006b: 51). De qualquer forma, não havia parteiras no sistema de parto katukina, porém com o advento dos cursos, algumas mulheres foram indicadas pelos caciques e comunidades para assumirem o cargo recém-criado de "parteira própria", tendo como sua nova atribuição o acompanhamento das gestantes e a assistência aos partos.

Entre os Kaxinawa, apesar da grande heterogeneidade de situações no que se refere à organização dos cuidados com a gestação e o parto no âmbito das aldeias desse povo indígena, também encontramos uma situação semelhante: "O evento do parto acontece no âmbito familiar e a assistência é fornecida pelas mulheres mais próximas em termos de parentesco" (Instituto Olhar Etnográfico, 2006b: 55). Muitos dos Huni Kuin que participaram dos encontros do Alto Juruá também afirmaram que até pouco tempo atrás não havia parteiras em suas comunidades. Essa realidade se desvelou durante as reuniões em muitos depoimentos prestados pelos participantes kaxinawa:

Antes eu era parteira, mas não sabia fazer parto. Nunca tinha acompanhado minha mãe. Por que só ela é que fazia o nosso parto. Daí a mãe veio pra Tarauacá e eu fiquei com a minha cunhada que tava pra ganhar neném. Eu não sabia de nada! Ninguém acreditava em mim. Tinha ficado eu e a minha irmã. Aí meu irmão foi chamar a minha irmã, por que ela era mais velha e acreditou mais nela. Mas a minha irmã não tinha coragem de fazer o parto. Aí, nesse dia, eu cheguei e comecei a fazer o parto. A criança já tava na hora de nascer. Eu não usei luva, a tesoura era a mesma que nós cortava pano, né? A gente não sabia nem como limpava a tesoura, esterilizava, nada. Nós usávamos só assim mesmo. Aí que melhorou muito, porque agora nós não usamos mais assim. Tem o material depois do curso. Depois que eu fui capacitada, ganhei o material: tesoura, balança pra pesar a criança, avaliar quantos quilos que nasceu; ganhamos a fita pra medir 
quantos centímetros a criança tem. A luva nós temos agora. Porque todas nós parteiras, eu acho, não faz mais o parto sem luva. Nós temos aquele álcool. Antes botava remédio pra colocar no umbigo quando cortava, fazia tratamento. Às vezes tirava um remediozinho da mata e passava no umbigo pra poder sarar. Então, minha mãe usava isso; eu nunca usei que nem ela. Eu não aprendi a fazer parto pelo tradicional não; eu aprendi no curso. (...) Antes ninguém conhecia a mulher grávida, que nem se diz! Depois da capacitação eu fiz 16 partos. Antes do curso, vamos dizer, todo mundo era parteira, né?! Até o marido da mulher fazia parto; a mãe dela... Depois do curso só eu que faço parto na minha aldeia. Agora em cada aldeia nós temos uma parteira.

Um AIS dessa mesma etnia afirma que em sua aldeia fazia aproximadamente seis anos que o cargo de parteira havia sido criado e que antes disso "qualquer um pegava menino". Segundo ele, as comunidades somente passaram a reconhecer e a respeitar as suas parteiras depois que elas fizeram os cursos.

Anteriormente, como já falaram aqui, qualquer um era parteira; as parteiras eram de qualquer jeito. Atuavam na necessidade de atender algum parto na aldeia. Hoje teve uma grande mudança através do conhecimento dos nawa. Porque nós índios estamos mais envolvidos com o mundo dos brancos. (...) Eu tenho um exemplo na minha comunidade. Há seis anos atrás a parteira era qualquer uma, dependia da necessidade. Depois que as parteiras foram reconhecidas, que pegaram um treinamento, receberam o kit com material que não existiam antigamente, foi que a comunidade indígena passou a respeitar a sua parteira. A partir de então ela pode acompanhar todas as grávidas, juntamente com o agente de saúde.

Uma parteira da mesma comunidade desse AIS reiterou a sua palavra ao relatar que, após os cursos, na sua aldeia não acontece mais de "qualquer um pegar menino" ou mesmo de a gestante escolher a pessoa que irá auxiliá-la no momento de dar à luz. As mulheres com experiência prática, mas que não participaram das capacitações, são autorizadas a "pegar menino" somente quando a "parteira treinada" não estiver disponível. "Agora mesmo não tem mais isso não! Quem pode acompanhar ou cuidar da mulher grávida é aquela que tem o curso. Agora, quando a mulher que é parteira porque fez o curso não está, aí a pessoa que entende pode fazer o parto".

Antigamente, mas não há muito tempo, além de qualquer um poder "pegar menino" dentre os parentes próximos, também havia a possibilidade de as grávidas decidirem parir sem recorrer à ajuda de ninguém. Nesses casos, elas se dirigiam à mata e voltavam para casa com seu filho nos braços. "Ela tá falando que agora tem parteira, mas que antes não tinha. As mulheres tinham seus filhos na mata, por lá mesmo cortava o umbigo e depois vinha pra casa. Mas agora ela é a parteira da aldeia dela, porque foi indicada pela comunidade, apesar de não saber escrever" (AIS traduz fala da parteira). 
Esses depoimentos indicam que a emergência da parteira em algumas comunidades kaxinawa instaurou um processo de reorganização dos cuidados prestados à gestação e ao parto, ao redefinir papéis e interferir sobre as relações estabelecidas entre os familiares e parentes concernidos no processo de produção de uma nova pessoa indígena. Ao instituir as parteiras que fizeram os cursos como aptas a acompanhar as gestantes e a assistir os partos, outras pessoas com experiência prática em "pegar menino" são desautorizadas a auxiliar as parturientes a darem à luz. Parece que a expressão "qualquer um pegava menino", ao mesmo tempo que adquire uma conotação pejorativa na voz de alguns cuidadores capacitados - tanto AISs quanto parteiras treinadas - expressa o quanto aqueles que participaram dos cursos adquiriram autoridade e distinção perante os demais membros da comunidade no que se refere aos cuidados com a gestação e o parto.

Entretanto, os cursos de parteiras são apropriados de diferentes formas pelas comunidades e pelas pessoas indígenas. Essa realidade se revela na fala de uma mulher kaxinawa que diz ter participado dos cursos não com o intuito de se tornar parteira, mas sim para incrementar os seus saberes sobre o parto, já que numa situação de necessidade eles poderiam ser úteis.

Eu também vou deixar a minha participação. Eu nunca peguei criança, não, porque nunca teve o momento de ter precisão. Sempre que eu tô junto da minha mãe eu acompanho ela. Eu já ajudei minha mãe a fazer parto de dois (...), já cortei o umbigo do meu sobrinho e dos filhos das minhas cunhadas. Na hora que minha mãe pega, ela manda eu cortar, aí eu corto. Agora, ainda não chegou o momento pra mim de fazer um parto! Mas se chegar, eu tenho certeza que pelo meu entendimento e pela orientação da minha mãe eu faço. Aquele curso em 2003 eu tive participando e ouvindo. Agora vim ouvir de novo porque tem momento que a gente que tem filho, tem filha, precisa. Tem dia que não dá tempo de chamar a parteira: as vezes é distante, as vezes é noite. Aí a pessoa se obriga a fazer o parto. Daí, tendo aquela orientação, a pessoa não fica nervosa, porque já entende um pouco.

Desse modo, os conhecimentos dos brancos podem ser úteis para qualquer mulher indígena que precise ajudar uma parenta a dar à luz. Aqui, o parto aparece como um evento cotidiano sobre o qual se tem um saber difuso, porquanto compartilhado pelas mulheres que passaram pela experiência do gestar e do parir e auxiliaram outras a trazerem seus filhos ao mundo. Dentro dessa lógica, todas aquelas que já pariram têm um saber prático sobre "pegar criança", o que as habilita a auxiliar quem está parindo. Parece ser essa uma das formas possíveis de apropriação e indigenização dos cursos de parteiras, colocando-os a serviço da reprodução do sistema de atenção ao parto kaxinawa, pelo menos.

O fato de a figura da parteira, como alguém próprio para acompanhar as gestantes e realizar os partos, ser recente não é unanimemente relatado entre todos os povos indígenas que participaram dos encontros no Alto Juruá. Os participantes 
Jaminawa-Arara, Nukini, Nawa, Yawanawa e Shanenawa mencionaram a existência de mulheres que se destacavam dentro das suas comunidades por serem referência na assistência aos partos. Em alguns casos, por terem conhecimentos especializados sobre o ofício do partejar, essas mulheres já eram denominadas parteiras, mesmo antes do advento dos cursos.

As Yawanawa afirmaram que sempre houve mulheres que sabiam fazer partos, mas não eram chamadas de parteiras e passaram a ser nomeadas dessa maneira mediante a realização dos cursos, quando aprenderam com os nawa que aquelas que "pegavam menino" eram denominadas parteiras. Porém, com o advento dos cursos, algumas mulheres sem experiência na arte de partejar, apoiadas pela comunidade e por suas lideranças a participar dos cursos, passaram a ter interesse de assumir o cargo de parteira da sua comunidade.

Eu participei do curso e achei muito importante! Eu fui apoiada pela minha comunidade e escolhida como parteira. Eu recebi até um certificado de parteira. Porque lá na minha comunidade não tinha nenhuma parteira, aí nossa liderança me escolheu. Aí eu participei e recebi um pouco de material que eles deram, naquela época, pras parteiras. Eu só participava, mas não tinha coragem de fazer um parto. Aí depois daquele curso eu aprendi muita coisa. Eu aprendi mesmo a fazer o parto. Depois daquela participação que eu tive, eu já eu fiz quatro partos lá na minha aldeia.

Ao que tudo indica, a existência de parteiras entre alguns dos povos indígenas do Acre é um efeito do contato interétnico estabelecido com a sociedade regional que tem uma conformação cabocla e nordestina (Instituto Olhar Etnográfico, 2006b). De qualquer forma, mesmo entre essas etnias, ao modificarem as práticas e o status das mulheres que "pegavam menino" dentro das aldeias, os cursos contribuíram para fazer surgir a parteira em sua manifestação contemporânea - as "parteiras capacitadas".

Assim, não se pode classificar os povos indígenas simplesmente como tendo a parteira instituída antes dos cursos e aqueles que passaram a tê-la após a sua realização. O fenômeno de emergência da parteira entre os povos indígenas do Alto Juruá é complexo e apresenta várias nuances. Se entre alguns povos, como os Katukina e os Kaxinawa, a figura da parteira emerge com os cursos, em outros a atuação das parteiras é transformada pelas capacitações. Nesse contexto, o que parece ser comum a esses povos - para além das diferentes formas que o processo de emergência das parteiras assume nos diversos contextos comunitários em que ocorre -, é o fato de a parteira emergir como um cargo.

Não devemos perder de vista a esse respeito que o papel oficial de parteira traz ganhos importantes em termos de prestígio dentro do grupo, já que a pessoa passa a ter uma relação privilegiada - junto com o AIS (...) e outras figuras 
criadas em termos similares - com as instituições governamentais. Existindo a perspectiva de que, em algum momento, se desenvolva uma política pública destinada à contratação de parteiras. A esse respeito, da mesma forma que outros cargos, a eleição de uma determinada mulher para ser parteira não está isenta de considerações de caráter político, sendo as famílias mais influentes as que conseguem monopolizar esses cargos. (Instituto Olhar Etnográfico, 2006b: 95)

\section{Indigenizando os cursos de parteiras indígenas}

Os discursos veiculados pelos participantes nos encontros entre parteiras, pajés e AISs no Alto Juruá, ao exporem uma avaliação dos cursos de aperfeiçoamento das parteiras tradicionais indígenas, revelam o quanto os povos indígenas ali representados veem nesses eventos uma forma de acessar não só os conhecimentos e materiais do kit parteira, considerados aqui símbolos do mundo do branco, mas também conquistar determinados direitos, recursos e benefícios advindos da interação com o Estado-nação.

Alguns estudiosos dos povos pano (McCallum, 2002; Lagrou, 2007) apontam para o fato de as coisas e habilidades dos brancos serem muito desejadas por eles. No caso Kaxinawa, por exemplo, as pessoas se suprem com "fontes externas de poder" advindas dessas interações com o estrangeiro - o nawa. "Os nawa são fonte de cobiçados poderes e produtos. (...) Os Huni Kuin continuam consumindo, retendo, casando, reproduzindo-se, produzindo e roçando nos interstícios dessas diferenças - entre si, mas ao alcance dos bens, remédios e saber fornecidos pelos nawa" (McCallum, 2002: 390).

Pode-se entender o desejo indígena pelos conhecimentos e pelas coisas do branco, expresso na fala dos participantes durante os encontros no Alto Juruá, como uma estratégia discursiva de apropriação e controle das relações estabelecidas com os não índios ao longo do processo histórico de contato interétnico. Nesse processo de apropriação, o branco é capturado e domesticado, em termos simbólicos, ao mesmo tempo que é seduzido a cooperar com os projetos indígenas de developman, geralmente voltados para a sua própria reprodução sociocultural. O financiamento dos cursos de parteiras, assim como os próprios encontros entre parteiras, pajés e AISs são exemplos concretos desse processo de conquista da colaboração não indígena, o que não quer dizer que todos esses povos ou mesmo comunidades diferentes de uma mesma etnia incorporam os conhecimentos e coisas do branco da mesma forma. Certamente, existe uma diversidade dos modos de apropriações.

Nas avaliações sobre os cursos das parteiras, os indígenas recorreram a categorias discursivas dicotômicas para estabelecerem contrastes entre a forma de parir nos tempos antigos e nos tempos atuais; entre o parto tradicional e o 
parto do nawa. Assim, a reflexão oscilou entre o jeito do branco de fazer partos e os cuidados indígenas com a gestante e a parturiente, qualificados pelas falas indígenas como tradicional ou cultural. No âmbito desses discursos, empregar ou não os conhecimentos e práticas aprendidos durante os cursos parece ser o sinal que indica se a parteira está operando de uma forma ou de outra. Possivelmente, esses enunciados variam de acordo com o contexto em que são proferidos. Se estiverem numa situação em que os conhecimentos do branco são valorizados, as parteiras afirmarão trabalhar do modo como aprenderam nos cursos; se as formas tradicionais de assistência ao parto forem reconhecidas, as falas enfatizarão que, apesar de as parteiras utilizarem alguns materiais do branco, elas continuam fazendo o "parto tradicional". Portanto, os discursos variam de acordo com as situações em que são proferidos e com os destinatários.

De qualquer forma, os conhecimentos e os kits parteira disponibilizados pelos cursos, ao serem apropriados pelas comunidades indígenas do Alto Juruá, adquirem novos significados e funções nos contextos socioculturais em que são reinscritos. Mas, ao deslizarem pelas fronteiras da diferença cultural e terem o seu conteúdo semântico esvaziado, os conhecimentos e coisas apropriados dão origem a novas formas de saber sobre a gestação e o parto e a novos lugares de poder, como no caso do cargo de parteira instituído com o advento dos cursos. Assim, redefinidos e incorporados, eles são postos em circulação a serviço do dinamismo social indígena, transformando-se em símbolos de exterioridade que conferem prestígio local (Albert, 2002: 12).

Nesse caso, o kit parteira pode ser entendido como um símbolo das relações de poder estabelecidas com os brancos e, por isso, validam a posição daquelas que o possuem: as parteiras. O kit é a materialização dos conhecimentos adquiridos durante os cursos, representando emblemas carregados de prestígio social. Possuir os materiais do kit sinaliza que essa mulher detém conhecimentos advindos do 'mundo do branco'. Constitui um sinal de distinção e de prestígio ante os demais membros da comunidade, assim como aumenta o poder de agência da parteira, na medida em que a autoriza a acompanhar as gestantes e a assistir os partos de sua aldeia, em razão da sua participação nos cursos. Como afirmou uma kaxinawa: "Agora não é mais qualquer um que pode pegar menino. Tem uma pessoa capacitada para isso". Portanto, mais do que um valor utilitário, os conhecimentos aprendidos e os kits recebidos legitimam a mulher que os possui a atuar como parteira.

Os discursos dos participantes indígenas dos encontros indicam que a própria organização do cuidado com a gestação e a prática do "pegar menino" entre os povos indígenas do Alto Juruá foram transformadas após a realização dos cursos de parteiras. Transformações marcadas pela apropriação dos conhecimentos e materiais do kit parteira, mas, principalmente, pelo surgimento da parteira como um cargo a ser ocupado por mulheres que participaram ou que desejam participar desses cursos. 
Dessa forma, os cursos, ao contribuir para criar o cargo de parteira, deslocaram do âmbito familiar e parental uma parte dos cuidados com a gestação e o parto, concentrando na personagem parteira o exercício de "uma prática que, tradicionalmente, estava difundida entre a população" (Instituto Olhar Etnográfico, 2006b: 95). Emerge, assim, uma nova forma de entender os cuidados com a gestação e o parto, enquanto os papéis sociais desempenhados por aqueles que cuidam das grávidas e parturientes são redefinidos. Ao mesmo tempo que relações assimétricas e não equivalentes, interdependentes e complementares, internas à sociedade, são criadas e mantidas pela posse desigual dos poderes e dos objetos advindos da relação com o estrangeiro - o nawa.

Entretanto, esses mesmos enunciados indicam que, apesar de alguns desses conhecimentos e de os materiais do kit serem incorporados à prática do "pegar menino", as mulheres não deixaram de operar com os saberes 'encorporados', isto é, inscritos em seus próprios corpos, adquiridos ao longo de sua trajetória de assistência ao parto. Apropriar-se dos conhecimentos e das coisas advindos do mundo do branco não significa substituir aqueles com os quais se vinha operando nas comunidades, mas sim acumular diferentes saberes e recursos para, atribuindo novos papéis e significados a tais conhecimentos e coisas nos contextos socioculturais dos quais agora fazem parte, transformá-los. Assim, ao serem incorporados na assistência ao parto, os conhecimentos e os materiais disponibilizados pelos cursos também são indigenizados pelos povos indígenas do Alto Juruá e, ao serem colocados em prática, tornam-se 'encorporados'.

O pensamento ameríndio parece valorizar o acúmulo do conhecimento encorporado, uma forma corporal-subjetiva de acumulação, ao invés de uma acumulação de relações através de artefatos. Este 'saber do corpo' estabelece relações ancoradas numa subjetividade que se constrói a partir do estar e se saber relacionado. (Lagrou, 2007: 81)

Se os cursos propiciaram a emergência da parteira tradicional indígena, eles fizeram isso por deterem o poder de nomear: aquelas mulheres que participam dos cursos, mesmo sem experiências em "pegar menino", tornam-se parteiras. Como prova da aquisição desse novo status, ela traz o kit parteira e o certificado de participação no curso. Portanto, ser parteira, nesse contexto, significa operar com os conhecimentos e com os materiais do branco. O poder de nomear dos cursos advém do fato de terem sido viabilizados a partir da relação estabelecida entre lideranças de mulheres indígenas e o Estado-nação. Se os cursos detêm o poder de nomear e, ao fazê-lo, de instituir realidades no âmbito das comunidades indígenas, é porque, embora não sejam profissionalizantes, estão alinhados aos discursos oficiais dos organismos internacionais e das políticas públicas.

Ao participar dos cursos de parteiras, as mulheres pano também aderiram ao processo subjetivo de tornar-se Outro, mesmo que parcialmente. Nesse caso, as 
mulheres estariam se tornando parteiras profissionais, isto é, um Outro habilitado a ser reconhecido não só no âmbito das comunidades indígenas, mas também pelos não índios, os nawa, aqueles que detêm o poder de reconhecer. É como se ao participarem desses eventos, as mulheres, inclusive aquelas que tinham prática em "pegar menino", fossem legitimadas aos olhos do branco para atuarem como parteira. Os cursos significaram rituais nos quais essas mulheres foram nomeadas parteiras, já que o movimento de mulheres indígenas, ao manter relações com o estrangeiro, tem o poder simbólico para tanto.

Ao serem nomeadas parteiras pelos cursos, essas mulheres se distinguem das demais integrantes da sua comunidade, principalmente daquelas que, ao possuírem experiência prática de "pegar menino", não são denominadas parteiras por não terem participado dos cursos.

Os efeitos e as consequências de oferecer cursos de capacitação para 'parteiras' indígenas não se limitam a uma 'melhoria' das condições sanitárias do parto indígena; acarretam também mudanças sociais, já que o atendimento do parto passa a ser prerrogativa de pessoas especializadas, e apontam para uma medicalização do parto, na medida em que se trata de suplantar as práticas tradicionais pelas biomédicas, mesmo que seja por meio de agentes indígenas. (Instituto Olhar Etnográfico, 2006b: 98)

Até porque os conhecimentos e coisas do branco apropriados pelos indígenas não deixam de trazer algo da sua sociedade de origem: esses cursos abordam as intenções oficiais do Estado e da OMS de regulamentar o ofício das parteiras e de integrá-las aos serviços de saúde. Assim, ao instituir um processo de profissionalização das parteiras, o Estado institui dispositivos de captura do outro que operam como artifícios para colonizar corpos e medicalizar as práticas e os praticantes indígenas que atuam na assistência ao parto. Embora o poder colonizador não necessariamente seja exercido pelos agentes coloniais de forma consciente, portanto, intencionalmente, não deixa de contribuir para concretizar o desejo colonial de ver os povos indígenas, socialmente subordinados na organização do Estado-nação, reformados por um projeto cidadão de inclusão social.

Todavia, embora tenha emergido a partir do advento dos cursos de capacitação de parteiras, a criação da "parteira própria" expressa a agência criativa desses povos ao instituir no âmbito de suas comunidades um papel especializado no acompanhamento das gestações e da assistência aos partos. Se por um lado a atuação dessa figura emergente está legitimada pelo fato de haver participado nos cursos, por outro, instituir um papel de 'parteira tradicional' também representa uma forma de continuar tendo acesso aos conhecimentos, coisas, recursos e benefícios advindos do mundo do branco, bem como de controlar as relações estabelecidas com o outro-nawa. 
No entanto, não só as parteiras são envolvidas no processo de gestação, parto e pós-parto. Os homens da comunidade - pajés, AISs e cônjuges - também desempenham um papel fundamental tanto nos cuidados voltados para a proteção e a promoção da saúde da mulher e do recém-nascido quanto no processo de fabricação de corpos e produção de pessoas engendradas e aparentadas, fenômenos que serão abordados no capítulo seguinte, quando será também destacada a importância do gênero na divisão das atribuições nas comunidades.

Notas

1 O Grupo Curumim, fundado em 1989, é uma ONG pernambucana feminista que tem como uma das suas linhas principais de atuação a capacitação das parteiras tradicionais como forma de humanização do parto no Brasil.

2 Segundo informações divulgadas em apresentação feita por ativistas da ONG Curumim em reunião no Ministério da Saúde em dezembro de 2008 em Brasília, durante esse período foram ministradas quatro capacitações de parteiras tradicionais.

3 Para maiores informações sobre o papel dos cursos das parteiras na transformação da assistência aos partos no Brasil, ver Tornquist (2004). 
Os cuidados com a gestação e o parto não dizem respeito apenas ao universo feminino (parteiras, mães, irmãs, primas, gestantes e parturientes), mas requerem a participação de homens - tanto dos que pertencem à família da grávida (pai, esposo, irmãos) quanto dos pajés e dos agentes indígenas de saúde (AISs) - na realização de algumas ações importantes para a saúde da grávida e da criança que está sendo forjada.

Os depoimentos dos participantes dos encontros entre parteiras, pajés e AISs demonstram que cada aldeia do Alto Juruá tem uma forma própria de organizar a atenção às gestantes, parturientes, puérperas e recém-nascidos. Nessa organização, são atribuídas a cada cuidador, sejam especialistas ou não, funções específicas e complementares nos cuidados com a gestação e o parto. E a posicionalidade de gênero ocupada direciona o exercício dessas atribuições.

Os pajés e os AISs, geralmente homens, desempenham papéis importantes nesse cuidado. Porém, o cargo de agente de saúde é oficialmente instituído pelo Estado, mas o de pajé não é um cargo formal. A categoria discursiva 'pajé' remete a uma ampla gama de especialistas - xamãs (Langdon, 1996) -, que, mediante práticas diversas, contribuem para a manutenção do bem-estar e da saúde da sua comunidade. Frequentemente, essas definições, que também emergem no contexto das relações interétnicas estabelecidas com o mundo dos brancos, são empregadas pelos indígenas para, ao falarem de seus especialistas, fazerem-se compreender pelos não indígenas.

De que forma, portanto, os papéis atribuídos aos pajés e AISs no cuidado com a gestação e o parto aparecem nos discursos proferidos pelos participantes das reuniões que ocorreram no Alto Juruá?

\section{A atribuição dos pajés no cuidado com a gestação e o parto}

O termo 'pajé' é utilizado para se referir a uma multiplicidade de xamãs que atuam nas aldeias indígenas tanto no que diz respeito aos seus diferentes per- 
tencimentos étnicos quanto às diferenças entre especialistas de um mesmo povo indígena. Mediante os depoimentos prestados pelos participantes das reuniões, permite-se entrever a diversidade de especialistas e a heterogeneidade das suas atribuições nos cuidados com a gestação e o parto. Os pajés que participaram nos encontros no Alto Juruá, majoritariamente, pertencem às etnias Katukina e Kaxinawa. Na reunião de Campinas, somente pajés katukina estiveram presentes, ao passo que nos eventos do Caucho e da aldeia Morada Nova foram predominantes os pajés kaxinawa.

Entre os Katukina há xamãs que possuem atributos próximos aos do mukaya (Kaxinawa): chama os espíritos quando quiser, tem uma substância mágica no corpo que pode se materializar na forma de objetos xamânicos, sabe mandar esta substância na forma de dardos invisíveis para vítimas e tem igualmente o poder de extrair estes objetos através da sucção dos corpos dos seus pacientes. O nome da substância amarga que foi introduzida no seu corpo pelos espíritos (yuxin ou yové) é rome: tabaco. (Lagrou, 2007: 387)

No caso katukina, quando ocorre algum problema durante a gestação ou quando a mulher está com dificuldades em parir, os pajés são chamados a intervir usando rezas para curar a parturiente e fazer com que a criança nasça. "Vários grupos pano localizados no Acre usam o termo português 'rezar' para se referir a uma técnica terapêutica que consiste na entoação de um tipo específico de canto de cura de caráter esotérico e incompreensível para aqueles que não são iniciados nos conhecimentos xamânicos" (Instituto Olhar Etnográfico, 2006b: 53).

Eu vou falar um pouquinho sobre o meu trabalho junto com essas parteiras que pegam criança. Eu não vou explicar melhor porque eu não sei português. Se a parteira vê que não dá pra ganhar neném naquela hora e momento, que já passou dias e dias sofrendo, elas me chamam pra trabalhar junto com elas. Aí eu vou fazer cura! Vou curar a mulher pra ela ganhar o neném logo. Eu conheço esse trabalho. Aí de repente elas ganham neném! (...) O nosso trabalho junto com parteira é rezar a mulher que vai ganhar neném. Não é todo o pajé também, não! Tem pessoa que não sabe trabalhar pra ganhar o neném. Às vezes luta, luta até que a mulher ganha neném pelo pé, pela mão. Então por isso tem aquele pajé que é profissional mesmo pra trabalhar. (Pajé katukina)

Portanto, o cuidado especializado prestado à gestação e ao parto é de responsabilidade dos pajés, cabendo-lhes tratar os agravos que podem acometer a mulher, tais como em caso de hemorragia, por exemplo. Nessas situações, as rezas também são utilizadas como recurso terapêutico para estancar o sangramento. Para diagnosticar as causas das doenças e saber qual método terapêutico empregar, o pajé precisa tomar uni (ay̧ahuasca). 
Ele tá colocando que, quando a mulher tá grávida, o pajé também acompanha e faz o trabalho dele. Quando a grávida tá sangrando, ele reza. Sangramento tem reza; escorrimento também tem reza. (...) Se a mulher, com três, quatro meses de gravidez tá sangrando ou com dor na barriga, ele faz reza pelo sangue. É algum espírito encostado na barriga dela que tá fazendo o sangramento. Aí o pajé reza, se ela ficar boa naquele dia, não precisa ser encaminhada pro hospital. Ou se ela tiver com corrimento, o pajé reza e faz a cura na aldeia. Ele toma uni (ayahuasca) pra ver o que tem na barriga da mulher; pra descobrir qual o espírito que tá encostado nela. Se o pajé não tá conseguindo curar, aí ela tem que ser encaminhada pro hospital. Porque se pajé não tá conseguindo, o agente de saúde também não consegue. Assim que o pajé faz o seu trabalho aqui na aldeia. (AIS traduz a fala de um pajé katukina)

Nos seus depoimentos, os pajés katukina procuram demarcar o seu campo de atuação junto às parteiras, enfatizando que não são todos os que sabem "trabalhar pra mulher ganhar neném". Por outro lado, as falas dos Katukina também remetem à diversidade de 'especialistas' englobados pela categoria pajé: além daqueles que rezam, existem os "sabedores das folhas" e os "curadores". ${ }^{1}$ Se ocorrerem problemas com o recém-nascido - por exemplo, quando o umbigo fica saltado em razão do pai ter trabalhado com terçado ou machado logo após o parto -, os "conhecedores das folhas" são chamados para preparar um banho para a criança.

Pode ser pajé, pode ser curador. E pode ter uma pessoa que só serve pra isso: que vai na mata e tira todas as folha e aí dá banho na criança pra ela parar de chorar. Aí se não resolver, procura o pajé pra rezar a criança. Mas, primeiramente ele tem que procurar a pessoa que sabe trabalhar na folha, pra dar banho com as folhas da mata. (AIS katukina)

Os pajés katukina também orientam os casais sobre os alimentos que devem ser ingeridos durante a gestação para evitar complicações no momento do parto. Se as gestantes ou mesmo seus cônjuges comerem algo não recomendado durante esse período, o pajé deve ser informado para neutralizar as influências deletérias que possam prejudicar o nascimento da criança, e, a fim de que não haja complicações na hora do parto, o pajé reza a caiçuma e a oferece à parturiente para que esta a beba.

Bom, vou falar um pouco. Lá na nossa aldeia, de um mês pra frente de gravidez nós não come tracajá, nem jacaré e nem jabuti. Nós não come! Se comer jacaré e jabuti, o nosso pajé cura na caiçuma pra não ter problema na hora do parto. (...) É só nosso pajé mesmo que cura nós. E depois, a nossa dieta quando nós ganha, nós deixa de comer macaco: o pai da criança, a mãe, os irmãos da criança também não podem comer. O menino fica chorão. Se nós comer depois que ganha neném, se o menino fica chorão nosso pajé cura na caiçuma e dá pra criança beber, aí ele para de chorar. Só posso falar isso mesmo. (Parteira katukina) 
Entre os Yawanawa também se usa a caiçuma, mas desta maneira: para prevenir problemas no parto, o pajé também reza a beberagem e a oferece à mulher durante a gravidez. Aos pajés cabe tirar as folhas na mata e entregá-las às parteiras, para que elas sejam preparadas e dadas à mulher no momento do parto na forma de beberagens, banhos ou massagens. Além disso, o pajé intervém logo após o parto, buscando folhas e preparando banhos para estimular o crescimento saudável do recém-nascido.

Já os Kaxinawa afirmaram ser atribuição dos pajés "tirar folha do mato" e preparar os remédios tradicionais não só para intervir em complicações que possam ocorrer durante a gravidez ou no momento de dar à luz, mas também para preparar um parto rápido e sem dor, prevenir padecimentos durante a gestação e o parto e desenvolver certas habilidades nas crianças.

Então, ele tava falando dos cuidados com as grávidas. No primeiro mês, quando para a menstruação, comunica pra ele. Aí ele já vai tirar o remédio pra dar banho e também pra tomar, pra que ela tenha um parto rápido. (...) Como outras pessoas falaram também, ele disse que a mulher grávida não pode comer tatu, nem jabuti, porque dá problema! A criança nasce com problema de cabeça e outras coisas. Sobre a dieta da saúde, ele faz o cozimento pras elas tomarem e cuida delas como pajé. Após a criança nascida, pra que ande mais rápido, ele também faz o remédio. É isso que ele falou. (AIS traduz a fala do pajé)

Mas o pajé que trabalha com os "remédios da mata" é um dos tipos de xamãs que existem entre os Kaxinawa. Outros também podem contribuir para o sucesso do empreendimento gestacional - a produção de uma nova pessoa indígena -, como, por exemplo, os chamados pelos participantes das reuniões de "pajé espiritual". E mesmo entre estes existem vários tipos que são identificados, ao que parece, de acordo com os métodos e técnicas por eles dominadas.

Então, eu vou falar aqui como pajé, né? Eu tô me lembrando aqui se eu tô mentindo... Não sei se é verdade mesmo. Mas tem diferentes tipos de pajé: tem pajé só pra medicina da mata; tem pajé que é só mesmo pra curar; tem pajé que é só mesmo do cipó, aquele que tá chamando, concentrando, pra vê como a gente tá; tem o pajé, como o parente fala, que chupa pra tirar a doença. Então não é só um tipo de pajé que tem! Tem vários pajés! (Pajé kaxinawa)

Ao que tudo indica, esses diferentes tipos de pajés estão situados entre dois polos: os que "tiram folhas" e trabalham com os remédios da mata, os dauya, e os que trabalham com o espiritual, o mukaya. "O dauya, 'aquele com remédio', mata e cura com o uso das plantas, e o mukaya, 'aquele com amargo', cura e também pode matar com a ajuda dos yuxin (espíritos) por meio da substância amarga muka que há dentro do corpo, e que é a materialização do poder xamânico" (Lagrou, 2007: 367). 
Lagrou (2007) afirma que os dauya e os mukaya são polos representativos de dois métodos usados pelos Kaxinawa para lidar com o bem-estar e com os infortúnios, mas que entre esses polos estaria situado um amplo espectro de praticantes que sabem usar tanto as plantas medicinais quanto lidar com os yuxin (espíritos), já que "as práticas relacionadas à cura são mais diluídas em uma preocupação com o bem-estar e o crescimento, e menos cristalizadas em papéis e especializações fixas" (Lagrou, 2007: 368). Porém, o fato de haver esses dois tipos de xamãs não quer dizer que haja uma oposição entre os tratamentos que eles realizam. Há doenças causadas por espíritos que também são tratadas com folhas do mato.

Quando uma criança chora muito de noite, entende-se que um yuxin está tentando levar sua alma, nesse caso folhas são queimadas para afastar os yuxin; quando uma pessoa é pega pelos yuxin, será com plantas medicinais espremidas nos olhos que ela será trazida de volta à vida normal; e se os yuxin da caça vêm, não para roubar a alma, mas para transformar o corpo da vítima em um deles, será novamente com plantas que os humanos os combaterão. (Lagrou, 2007: 399)

\section{O papel dos agentes de saúde no cuidado com as grávidas}

De acordo com os discursos veiculados durante os encontros do Alto Juruá, as principais funções desempenhadas pelo AIS em suas comunidades são: encaminhamento e acompanhamento de pacientes aos serviços de saúde; monitoramento do crescimento e desenvolvimento das crianças; acompanhamento das gestantes e dos demais "pacientes" que estão recebendo tratamento biomédico; fornecimento de primeiros socorros; apoio às atividades desenvolvidas pela Equipe Multidisciplinar de Saúde Indígena (EMSI) nas comunidades; levantamento de dados referentes à saúde dos membros da comunidade; realização de visitas domiciliares e palestras que tratam de temas específicos relacionados à saúde (Instituto Olhar Etnográfico, 2006b). Mas, no que concerne à atenção prestada à gestação e ao parto, o trabalho dos AISs se complexifica, até mesmo no que se refere à relação mantida com os demais cuidadores indígenas da saúde.

Um agente de saúde katukina conta que, quando as mulheres estão grávidas, ele pergunta se elas estão bem ou com fraqueza, se têm dor, corrimento, sangramento. E, se alguns desses sintomas forem identificados, ministra-se o "remédio da farmácia" que estiver à sua disposição. Caso essa medicação não solucione o problema, o agente é responsável por encaminhar a mulher aos serviços de saúde e acompanhá-la durante as consultas, relatando ao profissional - médico ou enfermeira - o seu quadro geral. No retorno da consulta, é ele quem "faz o tratamento" ao ministrar os medicamentos prescritos pelo médico. Dessa maneira, os agentes concluem que, ao fazerem o pré-natal da grávida, acompanham as gestantes 
da mesma forma que o branco. Constatação compartilhada por grande parte dos agentes de saúde que participaram dos encontros no Alto Juruá.

Entretanto, a maioria dos participantes desses eventos esclareceu que o AIS não atua no momento do parto propriamente dito, em virtude do fato de as parturientes se sentirem envergonhadas diante de outros homens. "O AIS lá da nossa aldeia não ajuda a fazer o parto. Ele ajuda no caso de injeção, de medir a pressão, medicamento que esteja precisando. É isso! Não é ajudar a parteira a fazer o parto. Entendeu? Porque a mulher não ia se sentir bem!" (Parteira jaminawa-arara). Os indígenas foram unânimes em afirmar a dificuldades dos AISs homens em lidar com os problemas íntimos de saúde vivenciados pelas mulheres de suas comunidades, pelo fato, por exemplo, de fazerem parte da rede de parentesco que conforma o contexto comunitário onde atua.

Para os participantes katukina, o AIS deve atuar somente após o parto, fornecendo os medicamentos necessários, na medida em que ele é o conhecedor dos "remédios de farmácia".

O agente de saúde mesmo, que trabalha com 'remédio de farmácia', só ajuda depois da mulher ganhar neném. Aí agente de saúde toma de conta, dá algum remédio, alguma pílula, alguma coisa. Agora, enquanto ela não ganhar neném, o trabalho é da parteira e do pajé. O pajé sabe trabalhar! Sabe como é! Ou então fica normal, ou então não. Ou então o menino vai nascer pela perna, ou pela mão, e neném vai ficar de jeito. Por esse motivo, só parteira e pajé que trabalham. O agente de saúde toma de conta depois da mulher ganhar neném, com o remédio da farmácia mesmo. (Pajé katukina)

Contudo, embora seja, aos olhos das suas comunidades, uma atribuição dos AISs administrar os "remédios de farmácia" aos pacientes, nem sempre os medicamentos básicos estão disponíveis.

A nossa preocupação é essa: falta medicamento básico. Isso é o que nós tamo precisando aqui pra trabalhar. Por que esses agentes de saúde antigos precisam de medicamento básico, esse medicamento anti-inflamatório. Eles precisam, porque já sabem aplicar no paciente. (...) A Funasa deixa pro agente de saúde só aquele soro velho, aquele paracetamol. Só dois comprimidos entregam pro agente trabalhar. Isso aí nós não trabalha nem uma semana, nem duas semanas. Acaba tudo! (AIS katukina)

Essa situação encerra um paradoxo constitutivo da posição de entremeio - entre a comunidade indígena e os serviços de saúde - ocupada pelo AIS. Se ele é quem detém o conhecimento acerca dos medicamentos, entendimento vigente entre aqueles que participaram desses eventos, por que a Fundação Nacional de Saúde (Funasa) não disponibiliza os remédios necessários para ele tratar os seus "pacientes" nas aldeias? Essas reivindicações são importantes por evidenciarem o 
quanto o AIS, ao ser apropriado e indigenizado pelos povos indígenas do Alto Juruá, emerge nos múltiplos contextos comunitários em que atua como um especialista em "remédios da farmácia".

Então, a questão do medicamento é certa. Eu dou razão pra equipe também, porque nem todos nós entendemos de medicamento. O ponto que eu acho errado, é que tem AIS que entende e eles não dão. Porque jamais eu como agente, vou dar um medicamento pra um paciente se não estou entendendo pra que serve aquilo. Jamais mesmo! Então, eles têm essa desconfiança: dizem que só pode ser dado pelo enfermeiro ou pelo auxiliar; que o agente está lá só pra anotar quantos dias de febre, pra contar o que foi que aconteceu enquanto eles não vieram. Mas se a pessoa já passou mal e enterram, eles vêm só ouvir a mensagem, a novidade do que foi que aconteceu. E o medicamento lá no município! (...) Hoje em dia tô ensinando o meu irmão sobre os medicamentos, a dosagem, pra que servem os horários. Então tudo isso eu ensino, pra o dia que eu sair ou que quiser pegar outro trabalho, eu tenho uma pessoa preparada que tem quase o mesmo conhecimento. Aí a pessoa não fica atrapalhada. (AIS kaxinawa)

\section{Agentes de saúde, parteiras e pajés: interações possíveis}

As relações de cooperação estabelecidas entre as parteiras e os AISs no cuidado com a gestação e o parto são recentes e se encontram em processo de construção. Essas relações passam a se desenvolver a partir do momento em que a parteira passa a fazer parte do "conjunto de cargos dedicados a preservar a saúde das comunidades, ao lado dos AIS e dos AISAN" (Instituto Olhar Etnográfico, 2006b: 91).

Ainda assim, os discursos veiculados durante os encontros do Alto Juruá revelam que a cooperação entre AISs e parteiras pode assumir formas diferentes nas múltiplas conjunturas comunitárias indígenas dessa região. Geralmente, o agente de saúde contribui com o trabalho da parteira, auxiliando-a a preencher os formulários com as informações relativas ao parto e ao recém-nascido; a realizar alguns exames na grávida, como auferir a pressão; a encaminhar as gestantes e parturientes aos serviços de saúde quando necessário; a ler os materiais didáticos distribuídos nos cursos, tais como o Livro das Parteiras (Brasil, 2000).

Um AIS kaxinawa relata a forma como, em sua aldeia, ele trabalha em parceria com a parteira no acompanhamento das gestantes, cabendo a ela fazer o "atendimento domiciliar" no momento de a mulher dar à luz. Em caso de problemas na gestação ou no parto, a decisão sobre tratar na aldeia ou encaminhar a grávida para os serviços de saúde é tomada em conjunto, mas a responsabilidade pelo encaminhamento é do AIS, além de ser ele mesmo quem decide se o paciente deve ser encaminhado ao pajé para receber a "medicação tradicional". 
Eu, como agente de saúde lá na minha aldeia, faço uma parceria com a parteira: a parteira faz o atendimento no domicílio na hora do parto, mas durante toda gravidez da mulher eu tô do lado da parteira acompanhando. A parteira pergunta às grávidas se elas tão bem. Se não está bem e depende de algum pré-natal, seja na aldeia, seja a ajuda do médico na cidade, a gente tem como responsabilidade remover as grávidas. Lá, na minha comunidade o agente de saúde, a parteira e os velhos que conhecem alguma medicina tradicional trabalham com educação e respeito. Só pode remover uma mulher pra maternidade ou pro posto de saúde pra fazer pré-natal, se a parteira e o agente de saúde tiver conhecimento. E não vir de qualquer jeito pra cidade. Vir por conta, dizer assim: 'Eu sou parteira e tenho toda a responsabilidade de levar a grávida pra cidade'. Isso aí lá na minha aldeia não acontece! (...) Hoje nós não temos mais de dizer assim: 'Não! O marido pode fazer o parto. Outra pessoa pode fazer!', porque a responsabilidade é da parteira e do agente de saúde. (...) E quando depende da pajelança, da nossa erva medicina, ela só pode ser utilizada com a autorização do agente de saúde e da parteira. Os velhos, as velhas que têm conhecimento, nunca vão chegar de qualquer jeito e dizer: 'Bom, isso aqui tá acontecendo assim, eu vou fazer esse tipo de tratamento, eu vou ajudar nessa parte!' Sempre ficam aguardando a decisão do agente de saúde e da parteira. O que não for do nosso conhecimento: 'Bom, seu Fulano, tá acontecendo isso, será que esse caso aqui nós podemos fazer essa medicação tradicional?'. 'Podemos sim!'. 'Então vamos lá!'. A pajelança fica a critério da gente lá na minha comunidade: da parteira e do agente de saúde. (AIS kaxinawa)

Outro agente de saúde kaxinawa também relata como atua em parceria com a parteira e o pajé da sua comunidade na busca de soluções para as complicações enfrentadas durante a gestação e o parto das mulheres huni kuin. A parteira dessa comunidade mantém um vínculo de parentesco consanguíneo com os AISs - ela é sua mãe -, mas é apresentada por ele como sua auxiliar, e o pajé é visto como um médico, especialista da tradição, consultado somente em último caso, quando todos os outros recursos empregados falharam.

Lá, o primeiro ponto que eu vejo é isso: o agente tá capacitado, pegou curso de formação, ele é formado. Então, no momento em que o agente tá formado, ele tem possibilidade de ensinar outra pessoa - o irmão, a irmã. Tá entendendo? Eu tenho uma auxiliar muito boa, só que ela não tá aqui, é a minha mãe, que é parteira. (...) Então, eu tendo uma parteira na minha aldeia, manera o trabalho pra gente, porque tem alguém pra tá trabalhando naquela área. (...) Então, a questão do pajé: nós lá utilizamos o pajé em último caso. Porque, eu não sei muita coisa, mas eu faço tudo que eu sei: eu rezo, dou remédio caseiro, dou da mata, dou os meus assopros, faço a minha cura. Se não deu, aí eu vou procurar o pajé. Por quê? Porque já vi que a minha força não deu pra curar. Se eu for pro pajé e ele não fazer cura, com certeza é algum tratamento prolongado, é uma operação, é uma coisa bem pesada. Então o pajé não fica todo o tempo e nem é todo o parto 
que ele acompanha, porque não é necessário. O pajé só se envolve quando a coisa é grande. O pajé é coisa séria, não é brincadeira mesmo não! O pajé está ali pra quando a pessoa está desesperada, não tem da onde tirar mais! Ele é o último recurso! o pajé é um médico, ele é muito importante. Tendo as três pessoas - o pajé, o agente de saúde e a parteira -, a gente vai passando tipo os não índios: quando o médico daqui não dá jeito, eles mandam pra fora. Não é verdade? Até chegar a solução. Então, a mesma coisa somos nós aqui. (...) Então, os pajés hoje em dia eles são os únicos que tem toda a tradição na cabeça! O pajé! Os outros estão aprendendo. Mas o pajé que é pajé, tipo assim, ele passou de grau já! Então primeiro vem ele, depois o agente de saúde que trabalha com a medicina da floresta e a medicina da farmácia. Então, é uma palavra por aqui. (AIS kaxinawa)

Esse AIS diz empregar todos os meios que conhece para tratar as doenças que acometem a sua comunidade: tanto as práticas chamadas tradicionais - remédios caseiros, rezas, assopros - quanto os "remédios de farmácia".

O agente de saúde reza, faz todo o trabalho e se não der certo, aí que vai pro pajé. E depois do pajé, depois que a mulher ganha neném, aí o agente de saúde se tiver um remédio, uma amoxilina, essas coisas assim pra inflamatório, ele usa. Então, ele contribui nessa parte aí. Se a mulher tá se sentindo mal ainda, porque às vezes ela ganha e fica com hemorragia, aí a pessoa vai lá e ele dá uma rezada. Seja o pajé ou outro (...), porque tem pessoa que sabe rezar, mas não é pajé. Então, o agente de saúde não tem um acompanhamento certo, do começo ao final. Mas no momento que a parteira tem dificuldade, ela faz parceria com o agente de saúde. Só envolve os dois no povo Kaxinawa. (...) O pajé acompanha na hora da necessidade, quando o neném vai nascer. Entendeu como é que é? (AIS kaxinawa)

Em algumas aldeias onde não há pajé, jovens estão estudando com os mais velhos as "ervas medicina". Em alguns casos, eles são AISs que, apesar de jovens, são procurados pelas pessoas por terem conhecimentos relativos à "medicina da mata". O interesse dos jovens pelo conhecimento dos mais velhos sobre as plantas e as práticas xamânicas pode estar relacionado à intensificação do fenômeno de revitalização cultural vivenciado por alguns povos indígenas do Acre (Instituto Olhar Etnográfico, 2006b).

Lá na minha aldeia não tem pajé, mas tem o nosso agente de saúde que conhece um pouco da medicina. Se os parentes o procuram, ele ajuda. Aqui no nosso grupo, não tem parteira mesmo; tem pessoas que pegam criança. (...) Também não tem pajé dentro da nossa comunidade, mas as pessoas tão aprendendo! Elas são novas, mas já têm um pouco de conhecimento.

Contudo, não são apenas os agentes de saúde kaxinawa que articulam os conhecimentos advindos do mundo do branco às práticas tradicionais de cuidado 
com a saúde. Entre os Katukina também se encontra um agente de saúde que diz trabalhar "tipo pajé" quando não consegue resolver um problema de saúde com os "medicamentos da farmácia". "Só que eu não sou pajé, sou agente de saúde, mas trabalho assim tipo um pajé! Quando o medicamento não tá conseguindo controlar, eu trabalho como pajé. Eu já curei várias pessoas, desde que tô trabalhando com essa experiência de cura" (AIS katukina).

Os depoimentos dos Katukina e dos Kaxinawa, portanto, indicam que os itinerários terapêuticos percorridos em casos de doenças, pelo menos em termos ideais, seguem este sentido: primeiramente, as pessoas buscam solucionar o problema de saúde no interior do grupo familiar. Se não encontram solução, recorrem ao AIS, que tentará tratar do caso com os recursos disponíveis - sejam os "remédios da farmácia", sejam os "remédios da mata" ou outras técnicas tradicionais. Se a solução não for alcançada pelo tratamento ministrado pelo agente de saúde, o doente será conduzido por ele ao pajé ou aos serviços de saúde. Ao passar pelo agente de saúde, o doente adquire o status de "paciente", incluindo as grávidas, como expressam os discursos dos AISs que participaram das reuniões. O pajé aparece como o último recurso terapêutico dentro da aldeia, a quem se recorre em caso de necessidade. Se, após passar por todas essas instâncias, a pessoa não for curada, é encaminhada para os serviços de saúde da cidade, atribuição própria dos AISs.

\section{O AIS como agente intermédico de cuidados com a saúde}

O cargo de AIS foi criado no contexto das relações interétnicas estabelecidas entre os povos indígenas e o Estado-nação no campo da saúde indígena. De acordo com a Política Nacional de Atenção à Saúde dos Povos Indígenas (Brasil, 2002), a formação e capacitação dos AISs é uma forma estratégica dos povos indígenas se apropriarem dos "conhecimentos e recursos técnicos da medicina ocidental, não de modo a substituir, mas de somar ao acervo de terapias e outras práticas culturais próprias, tradicionais ou não" (Brasil, 2002: 15). No documento "Educação profissional básica para agentes indígenas de saúde: modulo introdutório" (Funasa, 2005), determinam-se como atribuições dos AISs a realização de ações de vigilância em saúde, prevenção e controle das doenças e agravos por meio de visitas domiciliares; atividades educativas individuais, familiares e coletivas; e ações de atenção primária à saúde, sob a supervisão e acompanhamento de profissionais da saúde capacitados para exercerem essa função (instrutores/supervisores), pertencentes às equipes de saúde dos Distritos Sanitários Especiais Indígenas (DSEIs). Além disso, o AIS deve apoiar as equipes de saúde na adequação das suas intervenções à realidade sociocultural indígena, atuando como uma espécie de intermediador ou tradutor entre as comunidades e os profissionais da saúde (Funasa, 2005). 
No entanto, apesar de ser uma posição oficialmente instituída pelo Estado, diferente das posições não formais ocupadas pelas parteiras e pajés no cuidado com a saúde, o cargo de AIS também é apropriado pelas aldeias indígenas do Alto Juruá de distintas formas. Isso faz com que ele assuma funções e significados particulares nos múltiplos contextos comunitários em que atua. Desse modo, o papel do AIS, ao ser indigenizado, também surge nos discursos indígenas como emergente.

Os depoimentos indígenas prestados durante os encontros no Alto Juruá revelam que a posição que os AISs ocupam na relação com os demais cuidadores da saúde da comunidade e seu papel nos cuidados com a gestação e o parto sofrem variações dentro de cada uma das comunidades indígenas da região. Em algumas situações, ele está subordinado aos pajés e até mesmo às parteiras, chegando a ser aprendiz de pajé; em outras, as parteiras e até mesmo os pajés estão subordinados às decisões do AIS. Em alguns casos, os AISs mantêm relações de cooperação no cuidado com a saúde apenas com os pajés, não atuando nos cuidados com a gestação e o parto, por ser uma área em que atuam majoritária e preferencialmente mulheres; em outros, atuam como articuladores entre os diferentes cuidadores da saúde da comunidade, ora subordinando as parteiras e os pajés ao seu poder, ora subordinado a eles.

Em algumas situações, o AIS realiza apenas os procedimentos delegados a ele pela equipe de saúde da qual faz parte. Já em outras, combina os procedimentos biomédicos às técnicas e recursos terapêuticos tradicionais, ou ainda aplica em sua prática os conhecimentos sobre as "ervas medicina" aprendidos com os mais velhos. Por fim, ainda há os agentes de saúde que trabalham "tipo pajé" e outros que são pajés.

Então, eu vou falar aqui um pouco sobre a parteira. Esse negócio de parteira é complicado na nossa língua. Como o parente ali contou, também a velhinha contou ali: tão misturando nawa e nós, pra nawa entender e nós entender. Por exemplo, faz mal comer tatu que morre dentro do buraco, faz mal comer codó, faz mal comer poraquê, pra não sofrer de dor. Então, esse negócio é assim na nossa cultura, é isso aí que eu posso informar pra vocês. Por que se come poraquê quando tá grávida, a criança fica tremendo, dá aquele frioso. (...) Lá da minha comunidade, o pessoal me colocaram para mim me apresentar de pajé, mas eu trabalho como AIS também. Eu posso esclarecer esse estudo da ciência das parteiras que estão aqui. Vocês vão me desculpando, porque o que eu tinha pra dizer é isso. (Kaxinawa)

O domínio de técnicas terapêuticas, como a reza, não é uma atribuição apenas dos pajés. Em uma comunidade, existem muitas pessoas que sabem rezar e nem por isso são consideradas pajés. Além de algumas parteiras empregarem rezas na assistência ao parto, um AIS kaxinawa também reza, assopra e usa "remédios do mato" ao atender seus pacientes. O mesmo princípio postulado por ele para a atuação das parteiras também se aplica ao seu trabalho: usar tanto a forma não 
indígena quanto a indígena. Em sua ação ele combina procedimentos e práticas advindos desses dois horizontes socioculturais distintos; e no seu discurso estabelece distinções claras, caracterizando algumas práticas como indígenas e outras como nawa. Evidentemente, isso é feito com base em seu próprio entendimento indígena acerca do que são esses procedimentos e práticas do branco, que aparecem indigenizados em seu discurso.

Todavia, se há grande variação entre os arranjos organizacionais e hierárquicos na divisão do trabalho entre os diferentes cuidadores da saúde em cada aldeia e uma diversidade de práticas dos AISs em cada um desses contextos, os papéis desempenhados por estes também compartilham características comuns: os agentes de saúde irrompem nos contextos comunitários indígenas do Alto Juruá como conhecedores dos "remédios da farmácia" - uma das representações simbólicas dos indígenas sobre a "medicina do branco".

Além disso, é consenso entre os participantes dessas reuniões que cabe aos AISs o encaminhamento dos pacientes aos serviços de saúde localizados na cidade. O poder de encaminhar, ou seja, de estabelecer pontes entre o universo das aldeias e os serviços de saúde advém da relação que os AISs mantêm com o "mundo dos brancos", inclusive por ser essa uma das suas funções formalmente estabelecidas.

Como já foi dito, em algumas situações, o poder de encaminhamento dos AISs pode se sobrepor à agência das parteiras e dos pajés quando diagnosticam, prescrevem terapias e ministram tratamentos. Parteiras e pajés até podem fazer isso, mas somente se o agente de saúde houver encaminhado o paciente e concordar com o tratamento indicado. Dessa forma, o poder adquirido pelos AISs na relação com o mundo externo é deslocado para alguns dos contextos internos às comunidades. Assim, eles não só têm o poder de encaminhar os pacientes para os serviços de saúde, mas também de encaminhá-los aos pajés e de monitorar o trabalho das parteiras.

De fato, essa realidade é diferente em cada uma das comunidades do Alto Juruá, como foi dito anteriormente. Entretanto, o que emerge nos discursos indígenas como universal é que, ao instituir o AIS como interlocutor legítimo dos serviços de saúde nessa região, os pajés e as parteiras são desautorizados pelo sistema oficial de saúde a fazerem os encaminhamentos dos doentes aos serviços de saúde quando considerarem necessário. Nesse caso, tanto as parteiras quanto os pajés estão subordinados aos AISs. Esse processo inverte a lógica hierárquica na qual se pauta a organização do cuidado nas comunidades indígenas, como foi exposto por alguns participantes das reuniões ao afirmarem que os pajés são os "médicos" da aldeia.

Entretanto, o poder de encaminhamento do AIS não se deve apenas às relações formais mantidas com os serviços de saúde, mas também advém de uma de suas habilidades adquiridas, justamente, em razão da sua posição de gênero: são os homens que, além de serem os responsáveis pelas negociações estabelecidas 
com o mundo externo à aldeia, pilotam os barcos da comunidade, veículo no qual os pacientes dessa região, em sua maioria, são deslocados até a cidade. Portanto, no conjunto de cuidadores envolvidos na gestação e no parto, cabe ao AIS a tarefa de realizar a ligação entre o mundo indígena da aldeia e o mundo dos nawa - a cidade -, percorrendo os rios do Alto Juruá, que ligam um universo ao outro. Assim, seu lugar de atuação se localiza no espaço fronteiriço existente nas relações interétnicas mantidas entre esses povos indígenas e o sistema oficial de saúde.

Por outro lado, ao AIS está proibida a participação nos eventos de parto que acontecem em suas aldeias, reservando-se às mulheres essa tarefa. O AIS pode até participar de um parto, porém somente se a mulher que está dando à luz for sua esposa. Nesse caso, a identidade predominante é a de esposo e pai da criança, e não a de agente de saúde propriamente dita. O acesso do AIS à intimidade das gestantes é restrito em virtude do sentimento de vergonha que as mulheres nutrem para com homens que não fazem parte do seu círculo familiar mais próximo. Dessa forma, a posição de gênero coloca limites à possibilidade de atuação de cada um dos cuidadores comunitários da saúde indígena.

Nos discursos veiculados pelos participantes das reuniões no Alto Juruá, os AISs aparecem como agentes que recriam sua prática de maneira impressionante: ensinam seus irmãos sobre os "remédios da farmácia"; atribuem à sua mãe parteira o papel de auxiliar; trabalham com o cônjuge, instituindo-o como seu substituto; tratam os pacientes com práticas tradicionais e administram "remédios da farmácia"; e decidem se devem encaminhar os doentes para o pajé ou para o posto de saúde.

Nesses discursos, mencionam-se as articulações entre conhecimentos e práticas de saúde provenientes de distintos horizontes de tradição sociomédica - a indígena e a biomédica - realizadas pelos povos indígenas do Alto Juruá. Tal processo faz emergir novas formas socioculturais intermédicas de fazer saúde e de organizar os cuidados com a gestação e o parto. Ao incorporar os conhecimentos, as coisas e os procedimentos do branco, aprendidos durante os cursos de capacitação ou mesmo nas interações com os serviços e profissionais da saúde não indígenas e combiná-los aos saberes, recursos e técnicas já usados no cuidado com o bem-estar e a saúde dos membros de suas comunidades, os cuidadores indígenas - AIS, parteiras e pajés - desempenham papel importante no processo de emergência desses novos arranjos intermédicos. Assim, eles transformam os seus conhecimentos e suas práticas de modo a atualizá-los, ao mesmo tempo que reforçam a sua validade social nos múltiplos contextos comunitários em que atuam.

Como se vê, a aprendizagem entre os povos pano, à semelhança do que acontece entre os Kaxinawa, ocorre no campo da observação e da experiência prática. O processo social de produção de pessoas se associa à aquisição de conhecimentos e habilidades que são inscritos nos próprios corpos tornando-se, assim, 'encorporados' (McCallum, 1999; Lagrou, 2007). Porém, tais conhecimentos se consolidam, na medida em que são postos em prática no exercício de sua agência, demonstran- 
do domínio ao colocá-los a serviço da produção de "efeitos desejáveis no mundo" (Lagrou, 2007), como, por exemplo, a construção de um novo ser que começa a ser forjado durante a gestação. Conhecimento e agência, aspectos constitutivos da pessoa, estão intimamente conectados, pois estão inscritos em seu corpo, que é tanto produto da agência dos outros quanto agente na produção de outros corpos indígenas. Nesse caso, os conhecimentos e as agências acessados nos cuidados com a gestação e o parto também podem ser considerados como 'encorporados'.

Dessa forma, os conhecimentos, as coisas e as condutas do branco, apropriados e indigenizados pelos povos indígenas do Alto Juruá, mesmo que provenientes do estrangeiro, consolidam-se ao serem colocados em prática pelos cuidadores indígenas - que, no caso considerado, principalmente, são os AISs e as parteiras -, tornando-se assim um saber 'encorporado', porque prático e inscrito no corpo. $\mathrm{O}$ aprendizado dos procedimentos de higiene e do manuseio de determinados materiais do kit parteira durante os cursos de parteiras, por exemplo, requer a adoção de condutas e o desenvolvimento de habilidades corporais específicas para operacionalizá-los. Atualmente, é preciso lavar as mãos e escovar as unhas ou então aprender a usar luvas para evitar que o recém-nascido escorregue das mãos, aprender a esterilizar e manusear a tesoura para cortar o cordão umbilical, assim como a utilizar o pinard para auscultar o coração do feto. Da mesma forma acontece com os conhecimentos e procedimentos aprendidos pelos AISs em sua atuação junto às EMSIs e durante os cursos de capacitação de que eles participam.

Os agentes de saúde incorporam em sua prática e em seus próprios corpos os conhecimentos, as coisas e as condutas aprendidas nas relações mantidas com os representantes do modelo médico hegemônico. Em sua atuação, esses diferentes tipos de conhecimentos indígenas e não indígenas são acomodados de diversas maneiras, resultando em um processo contínuo de recriação dos saberes práticos que informam a sua ação. Igualmente as parteiras, ao atuarem em um campo configurado pelas relações de intermedicalidade, apropriam-se e incorporam os conhecimentos e coisas veiculados pelos cursos de parteiras e os aplicam na assistência que prestam às gestantes, parturientes, puérperas e recém-nascidos indígenas.

Portanto, a apropriação dos conhecimentos, coisas e condutas do branco se concretiza quando esses cuidadores desenvolvem sobre eles um domínio corporal. Ao operacionalizar os conhecimentos dos nawa em sua prática, já orientada pelos saberes previamente inscritos em seus corpos por meio de experiências práticas, as parteiras e os AISs também tornam tais conhecimentos 'encorporados', o que os transforma em agentes intermédicos. A intermedicalidade, além de configurar o contexto de atuação desses cuidadores, inscreve-se em seus corpos e se manifesta em sua prática, no momento em que o saber-fazer relativo à saúde é aplicado. 


\section{Agência e atribuições de gênero nos cuidados com a gestação e o parto}

Além dos pajés e dos AISs, que prestam cuidados às gestantes e às parturientes, os cônjuges desempenham um papel fundamental para o sucesso do empreendimento gestacional tanto pelo fato de, geralmente, serem eles os responsáveis pela alimentação da grávida quanto por contribuir com uma das substâncias vitais (o sêmen) para a produção de um novo ser.

Entre as comunidades indígenas representadas nos encontros do Alto Juruá, a distribuição da agência, um fenômeno instituído pela organização sociocultural de cada sociedade, é influenciada pela identidade de gênero. Isso porque, o "trabalho cultural envolvido na construção e distribuição da agência [faz] parte do processo que cria pessoas apropriadamente definidas em termos de gênero e, assim, entre outras coisas, diferencialmente empoderadas" (Ortner, 2007: 58-59). Todos aqueles que participam do processo relacionado à gestação e ao parto atuam de acordo com as diferentes posições em que estão situados. Isso faz com que sua inserção nesse empreendimento ocorra de diferentes formas.

O papel de cada pessoa envolvida no cuidado com gestantes, parturientes, puérperas e recém-nascidos, inclusive as parteiras, os pajés e os AISs, é limitado pelo papel desempenhado pelo outro que também participa desse processo. Portanto, as agências requerem uma constante negociação entre os concernidos, na medida em que o sujeito só pode agir segundo a posição que ocupa na rede de relações sociais na qual está situado. Os discursos proferidos durante os encontros do Alto Juruá tratam do caráter relacional da agência: as pessoas agem tendo outras em mente, dentro do campo de possibilidades de ações estabelecidas por suas posições engendradas. "A mulher enquanto mulher, agindo com outro em mente, age também de uma posição que é sua. (...) Há posições a partir das quais as pessoas agem" (Strathern, 2006: 414-415).

A posição ocupada pelo agente o inscreve em um contexto de relações múltiplas, o que faz com que ele se mova de uma posição a outra e, a cada ação, ative um tipo de relação específica, revelando as suas múltiplas capacidades. Ao observar a agência da gestante indígena, ver-se-á que ela ativa diferentes relações durante a gravidez: com o seu cônjuge; com sua mãe ou com a parteira que a assiste no momento do parto; com os pajés e os AISs quando a eles precisa recorrer. Portanto, uma mesma pessoa pode ocupar diferentes posições e, ao fazê-lo, acessa outro conjunto de relações. Isso foi evidenciado também no decorrer das reuniões. Em algumas situações, homens às vezes se pronunciavam ora como AIS, ora como pajé, ora como marido; da mesma forma as mulheres - ora falavam como parteiras, ora como mães, ora como esposas. ${ }^{2}$

O corpo é o lugar em que as distinções de gênero são inscritas. Essas distinções operam como um dispositivo organizacional das próprias relações, na 
medida em que permitem classificar as pessoas como mulheres ou homens. Para agir de determinada maneira, a pessoa deve estar habilitada pela sua identidade de gênero. Se assim for, a própria ação é engendrada.

O comportamento das pessoas revela necessariamente tanto a sua própria condição quanto a de outros: o comportamento é marcado por gênero. (...) São, portanto, os atos das pessoas que estabelecem o gênero do comportamento, tornando aparente a condição de seus próprios corpos/mentes, assim como a dos outros. (Strathern, 2006: 433-434)

A delimitação entre as áreas de ação de homens e mulheres cria uma diferença de valor entre tipos de ação apropriada a cada agente. De acordo com Strathern (2006), isso constitui uma fronteira ideacional que delimita a própria possibilidade de ação dos agentes dentro de um mesmo tipo de atividade ou processo. Esse é o caso, por exemplo, dos cuidados prestados à gestação e ao parto entre os povos indígenas do Alto Juruá. Por isso, convém considerar de que forma as relações de gênero entre os Kaxinawa são exemplares nos processos de produção de corpos e de pessoas aparentadas, ou seja, posicionadas em uma rede de relações de parentesco, e engendradas, isto é, portadoras de uma identidade de gênero socialmente construída.

\section{Pessoa e gênero entre os Kaxinawa: um caso exemplar}

Nos sistemas de parentesco ameríndios, a corporalidade constitui um idioma simbólico focal que operacionaliza e informa a práxis no âmbito das sociedades indígenas. Por meio das relações corporais, a interação entre as pessoas é instrumentalizada, na medida em que a partilha de substâncias é estruturante dessas relações. As teorias nativas de corporalidade (Seeger, 1980; Seeger, Da Matta GViveiros de Castro, 1987), tais como as relacionadas à concepção, à reprodução e aos ciclos vitais, remetem aos processos de formação e construção da pessoa social que acontecem por meio da fabricação e da modelagem do corpo (Viveiros de Castro, 1987). Portanto, é o idioma da substancialidade, baseado na conexão física e nas substâncias compartilhadas entre os integrantes de uma mesma família, que informa o processo de produção da pessoa aparentada e também da identidade de gênero.

Entre os Kaxinawa, as habilidades de homens e mulheres se unem de forma complementar para a produção de um novo ser. Enquanto o homem modela o feto no útero da esposa, a mulher cozinha os fluidos - sangue e sêmen - em seu corpo para forjar o feto (Lagrou, 2007). A pessoa kaxinawa tem duas almas (yuxin): a alma do olho e a alma do corpo que contém o conhecimento e a memória 
adquirida durante a vida (McCallum, 1999: 162-163). É por ter yuxin que a pessoa tem consciência, agência e intencionalidade. Assim, a pessoa surge como "corpo pensante".

Carne torna-se corpo quando imbuída com espírito ou agência (yuxin). (...) Sua origem é yuxin feito matéria, líquido sem forma, endurecido e modelado na solidez do corpo humano. O sangue feminino coagula através da repetida mistura com o sêmen e deste modo, o feto, um tunku (bola), está sendo modelado. Esse processo é visto como uma união das capacidades produtivas femininas e masculinas em que a mulher cozinha a criança em seu útero enquanto o homem dá a estrutura de sustentação, esculpindo sua forma. Essa modelagem e cozimento são considerados trabalho pesado e quando estão trabalhando em uma criança, o casal despende muito tempo na rede e na floresta. (McCallum apud Lagrou, 2007: 303)

Para os Kaxinawa, o corpo (yuda), dotado de agência e de capacidade para sentir, pensar e agir, é a pessoa - "o 'eu' pensante e o agente sensível responsável por seus atos. O corpo vivente trabalha e produz resultados no mundo em forma de artefatos, pessoas, roças, caça, etc." (Lagrou, 2007: 315, 324).

A definição de corpo é estar vivo, um ser social que tem percepção, se move, fala e pensa. Quando o yuda, o corpo pensante, é ativo e completamente saudável, seus yuxin estão imersos no corpo. (...) O conhecimento não é atribuído aos yuxin da pessoa, mas ao seu yuda (corpo). O conhecimento de como produzir efeitos desejáveis no mundo é percebido enquanto um conhecimento encorporado. (Lagrou, 2007: 309, grifos do original)

Os conhecimentos 'encorporados' apenas fazem sentido quando as pessoas têm "familiaridade com o desempenho e o pôr em prática das técnicas que incorporam tanto conteúdo quanto intenção" (Lagrou, 2007: 309). Se assim for, os conhecimentos relativos à gestação e ao parto também estão inscritos, antes de qualquer coisa, no corpo dos agentes envolvidos no processo social de produção de uma nova pessoa.

Conforme afirma McCallum (1999), as diferenças de gênero passam a ser inscritas nos corpos das crianças huni kuina partir dos 7 anos, aproximadamente, quando elas estão aptas a participar do ritual do nixpupima, ${ }^{3}$ por meio do qual meninos e meninas são transformados em corpos adultos fortes, saudáveis e engendrados, e seus hábitos e pensamentos são remodelados de modo que, a partir de então, façam parte da comunidade. "A comunidade de parentes próximos com os quais se vive é chamada 'nosso corpo' (...). Através da convivência, as pessoas acabam pertencendo ao mesmo corpo coletivo: compartilham memórias e substâncias" (Lagrou, 2007: 538).

A partir do nixpupima, o jovem adquire uma nova identidade com a qual será reintroduzido na vida social cotidiana. Desde então, deixa de ser um "receptor 
passivo de cuidados" e passa a ser um "produtor ativo de comida e de relações sociais", passando a ser "capaz de pensar por si mesmo" (Lagrou, 2007: 439). Somente nesse momento, os jovens estão aptos a adquirir conhecimentos específicos relacionados ao seu gênero. Os rituais de iniciação realizados após essa passagem trabalham as diferenças a fim de instituir "a interdependência dos gêneros e das capacidades produtivas e reprodutivas de homem e mulheres" (Lagrou, 2007: 442).

Para McCallum (1999), baseadas nas capacidades pessoais de homens e mulheres de produzir e reproduzir, na sua agência, as relações de gênero entre os Kaxinawa constituem mecanismos de construção de corpos e produção de pessoas aparentadas e engendradas. Nesse sentido, "construir o corpo envolve inscrever diferenças em forma de gênero" (McCallum, 1999: 160). Assim, o gênero é inscrito nos corpos dos jovens por meio das várias ações executadas por seus parentes mais velhos, que contribuem, assim, para transformá-los em pessoas adultas e engendradas.

Os avós maternos produzem a diferenciação de gênero em corpos que os pais da criança produziram anteriormente através do sexo repetido e depois pela alimentação. É central nas teorias pedagógicas Kaxinawa a ideia de que a produção corpórea deve correr paralelamente à produção da memória e do conhecimento na pessoa. Enquanto uma criança está crescendo, é a relação dos pais com seu corpo que se torna absolutamente importante, e instituições como a couvade e as restrições pós-natais impostas à mãe garantem um crescimento corporal bemsucedido. (...) Os avós devem assumir a responsabilidade pela produção corporal adulta nos adolescentes, paralelamente ao cuidado contínuo com os pais. A avó preside o isolamento da menina durante a primeira menstruação e prepara seu corpo para o aprendizado de técnicas femininas como a tecelagem, enquanto o avô materno cuida da produção dos corpos masculinos, apropriados para trabalhar na roça, caçar e pescar. Assim, os avós maternos têm um duplo papel; eles não só transmitem conhecimento aos filhos de seus filhos como também preparam a criança para a aquisição corporal do conhecimento e para sua realização física. (McCallum, 1999: 161-162)

Todavia, para se tornarem adultos, os jovens devem ter condição de suprir as necessidades de consumo de seus parentes e terem desenvolvido a capacidade de procriar. A pessoa adulta é aquela que está pronta para ter seus próprios filhos, bem como para produzir e distribuir alimentos e bens entre os seus parentes. Assim, o fundamento da sociedade kaxinawa se estabelece na relação existente entre o ciclo da produção, distribuição e consumo de alimentos e o ciclo do sexo, da procriação e da reprodução. "A produção cultural do gênero está ligada ao processo econômico, de modo que somente adultos produtivos são totalmente genderizados [portadores de uma identidade de gênero], e somente adultos genderizados são pessoas completas" (McCallum, 1999: 160-161). 
Portanto, as diferenças entre os gêneros masculino e feminino estão relacionadas às suas respectivas habilidades produtivas, aprendidas por meio da observação e da prática, quando a agência social é gradativamente adquirida. "A maior parte do processo pedagógico envolve a observação, por parte dos alunos, das ações do professor, ao invés de se basear no aprendizado através de explicações." (McCallum, 1999: 163). Dessa forma, adquirir agência equivale a conquistar conhecimentos 'encorporados' por meio de intervenções práticas. No processo de aquisição de gênero, duas modalidades de agências são forjadas: a masculina e a feminina.

Tanto a produção quanto a reprodução dependem da agência de outros: a produção masculina depende da feminina e vice-versa. A agência masculina inclui manter relações de troca com o 'exterior', enquanto a feminina envolve transformações no 'interior'. Porém, é a interação de ambas que constitui a socialidade e funda a organização social, que deve ser vista como um processo dinâmico. (McCallum, 2002: 391)

As operações caçar, realizada por homens, e tecer e cozinhar/transformar, realizadas por mulheres, englobam não só as atividades relativas à alimentação, mas também envolvem o ato de gestar, quando se está cozinhando o feto no útero, e de parir, momento em que aquilo que está sendo cozinhado se revela ser humano. A gestação de uma nova pessoa não ocorre em um único evento, mas sim em um processo acumulativo no qual se faz necessário o envolvimento da mulher e do homem: para "cozinhar bebês" em seu útero, a mulher depende da agência do homem. Portanto, "a complementaridade entre os gêneros também se dá nas substâncias empregadas para constituir o novo corpo" (McCallum apud Lagrou, 2007: 217-218).

A mãe e o pai contribuem com fluidos vitais para a formação e características da criança. Como na maioria dos povos amazônicos, prescrições alimentares são observadas durante a gravidez pelos pais, porque as substâncias consumidas constituem o sêmen e o sangue influenciando a forma, comportamento e qualidades da criança, além do próprio processo do parto. (Lagrou, 2007: 223)

A mulher adquire a capacidade de transformar, associada ao processo de "fazer bebês", a partir da sua primeira menstruação. Nesse momento, está apta a produzir a substância (sangue) que, juntamente com a substância masculina (sêmen), será transformada, por meio do cozimento, em uma criança. "A agência feminina envolve a capacidade de produzir vários objetos, de pintar, de tecer padrões decorativos e de transformar substâncias cruas em coisas ou pessoas cozidas ou processadas. Essas coisas são denominadas verdadeiras" (McCallum, 1999: 167-168).

Já o processo de engendramento do homem ocorre de modo diferente: na idade em que as meninas menstruam pela primeira vez, os meninos começam a caçar e a trabalhar na roça. Nesse momento, é realizada uma série de rituais 
privados para a aquisição de habilidades de caçador e de trabalhador. As técnicas de caça são obtidas por meio de visões diurnas (olhares e lembranças) e de visões oníricas - sonhos e visões com nixipae (ayahuasca)4 - causadas pelas andanças da alma do sonho (McCallum, 1999). Para aprender a caçar, os meninos devem observar as proibições alimentares e seguir a orientação do avô paterno.

Há uma associação secundária entre as mulheres e o sangue fresco que reforça a sua inadequação para a caça (as fronteiras entre o mundo humano e o animal são diluídas). Elas são responsáveis pela transformação da carne crua em comida cozida, retalham a maior parte da caça, distribuem a carne crua às mulheres da família e a cozida a parentes de ambos os sexos e aos visitantes. Boas cozinheiras não podem ser boas caçadoras. Da mesma forma, bons caçadores não podem ser bons cozinheiros. Assim, os homens precisam da agência feminina se quiserem consumir o produto de sua caça, assim como as mulheres precisam da agência masculina para produzir uma refeição completa. (...) Se um domínio invade excessivamente o outro (...) a agência genderizada é bloqueada: o homem se torna sem sorte na caça e a mulher perde a sua capacidade de fazer bebês humanos. Elas podem parir gêmeos e monstros deformados. (...) É por causa das naturezas opostas, mas complementares das agências masculina e feminina, culturalmente produzidas, que o treinamento formal das moças e dos rapazes assume a forma que tem. (McCallum, 1999: 173)

\section{Complementaridade entre gêneros nó cuidado com a gestação e parto no Alto Juruá}

Os discursos dos participantes indígenas indicam que as atribuições de homens são diferentes das desempenhadas pelas mulheres nos cuidados com a gestação, o parto e o pós-parto nas comunidades representadas nos encontros. Se à parteira cabe "pegar o menino" que está nascendo, o AIS tem a responsabilidade de encaminhar a mulher e o bebê aos serviços de saúde e a habilidade de pilotar os barcos para levá-los à cidade quando necessário.

As interações entre os cuidadores das gestantes, parturientes, puérperas e recém-nascidos estão informadas pela atuação engendrada de diferentes tipos de agentes: desde a grávida e seu esposo até as parteiras, pajés e AISs. Cada um desempenha funções e responsabilidades específicas que lhe cabem, segundo a posição que ocupam na organização comunitária do cuidado à saúde. A possibilidade de agir desta ou daquela maneira depende do gênero, que demarca, pois, diferentes tipos de agência.

À mulher cabe gestar e parir e, nesse processo, decidir a quem comunicar sobre a sua gravidez e quais os cuidados que observará enquanto estiver grávida (dietas, remédios tradicionais, condutas). Além disso, cabe a ela decidir, no exercício 
de sua agência, qual o tipo e a posição do parto e a quem recorrer para auxiliá-la no momento de dar à luz: à parteira da comunidade ou aos serviços de saúde. Pode contar, além disso, com a ajuda de sua mãe, de seu esposo, de outras parentas ou mesmo optar por ter sua criança sozinha - na mata, na roça ou em casa. Isso não quer dizer que outras pessoas pertencentes à sua rede de relações não influenciem a sua decisão. Entretanto, cabe a ela dar a palavra final quanto ao modo de fazer nascer o seu filho (a). É a gestante que, em última instância, tem poder para decidir sobre o seu corpo e a capacidade para intervir sobre os eventos que nele ocorrem. No caso Kaxinawa, a capacidade de decisão da gestante advém do fato de seus conhecimentos acerca do gestar e do parir serem parte constitutiva da própria pessoa, estando inscritos em seu corpo. Esse saber-fazer 'encorporado' é compartilhado por aquelas mulheres que vivenciaram essa experiência prática.

Gestar, no sentido de preparar em seu útero uma nova pessoa, e trazê-la ao mundo no ato de parir, compreende eminentemente uma atividade de mulher. $\mathrm{O}$ parto, como ato de expelir o feto, também cabe apenas às mulheres. Entretanto a relação estabelecida entre marido e mulher é fundamental no processo de produção dessa nova pessoa durante a gestação e também no evento do parto. O esposo partilha com a sua mulher grávida a necessidade de observar determinadas dietas alimentares e manter certas condutas para que o empreendimento gestacional tenha sucesso, e o recém-nascido nasça com saúde. Até porque ele desempenha um papel importante na formação do feto no contexto das relações de substância estabelecidas entre cônjuges. Cabe ao marido, conforme os depoimentos dos participantes dos encontros, alimentar a mulher durante a gestação, fornecendo, por meio da caça e da pesca, os alimentos adequados à sua dieta.

Portanto, nota-se que, entre os povos indígenas do Alto Juruá, a mulher não é considerada o único agente no processo de gestar e parir. As crianças, como constructo sociocultural, são resultados de múltiplas interações entre vários outros. Isso porque "as mulheres produzem como um ato social e, portanto, também em virtude dos esforços dos homens nessa matéria" (Strathern, 2006: 456-457).

Entre os povos indígenas do Alto Juruá, todas as modalidades engendradas dessas agências são interdependentes e complementares, visando ao sucesso do empreendimento gestacional. De forma sintética, foram mencionadas algumas das atribuições desempenhadas pelos agentes envolvidos nos cuidados com o processo de gestar e parir, de acordo com a sua posição de gênero.Em resumo:

Ao esposo cabe alimentar a gestante, cumprir as dietas prescritas e contribuir com as substâncias necessárias para a formação do feto; chamar ajuda em caso de complicações na gestação ou no parto; e auxiliá-la no momento do parto.

A parteira tem como função assistir os partos quando chamadas. Depois dos cursos de aperfeiçoamento, algumas delas passaram a acompanhar a gestação das mulheres de suas comunidades. 
Os pajés, entre os Kaxinawa e os Katukina, são chamados a intervir quando há alguma complicação na gestação e no parto. Também agem para prevenir doenças na mulher e no recém-nascido e para promover o desenvolvimento de certas características e habilidades na criança.

Aos AISs cabe monitorar e informar as equipes de saúde a situação da grávida, prescrever "remédios da farmácia" ou fazer outros tipos de tratamento; encaminhá-la aos serviços de saúde quando necessário. Uma de suas habilidades é pilotar os barcos para deslocar a gestante para a cidade. Dessa forma, eles continuam a exercer uma atividade relacionada tipicamente aos homens: estabelecer contato entre 'mundo tradicional' e 'mundo dos brancos'. Eles não auxiliam na hora do parto, justamente em função de sua posição de gênero: as mulheres sentem vergonha de revelar sua intimidade para homens que não fazem parte do seu núcleo familiar mais próximo.

No próximo capítulo, contemplar-se-ão os enunciados indígenas que abordam as práticas de autoatenção empregadas no decorrer da gestação e do parto que, além de garantir a saúde da mulher e do recém-nascido, também fazem parte dos processos socioculturais de produção de corpos e de pessoas aparentadas entre os povos indígenas do Alto Juruá. Ao se analisar o processo de emergência de categorias discursivas híbridas, tais como a do pré-natal tradicional, perceber-se-á o quanto a noção medicina tradicional indígena assume um caráter emergente ao ser reconstruída em seus sentidos nas situações dialógicas em que é colocada em pauta.

1 "Coffaci (2000: 128) chama a atenção para a existência de um dualismo de xamãs entre os Katukina, que atribuem mais poder ao romeya (...) do que ao rezador (shoitiya ou koshoitiya), porque o último não teria o poder de curar feitiço" (Lagrou, 2007: 376).

2 Entre os povos melanésios, a maternidade se constitui em uma situação que ativa inúmeras relações, revelando o caráter relacional da agência: "As mulheres fornecem evidência de sua própria capacidade de ação, assim como da capacidade das outras, através do evento do parto e da singularidade constitutiva de seus próprios corpos" (Strathern, 2006: 406).

3 O ritual do nixpupima, em que os dentes dos jovens são ritualmente enegrecidos, marca a passagem da infância para a adolescência (Lagrou, 2007: 439).

4 A ayahuasca constitui numa infusão do cipó Banisteriopsis caapi e da folha Psychotria viridis, além de diversas plantas que podem ser acrescentadas à bebida (Labate, 2002). 


\section{Folhas, Rezas e Dietas: a emergência da medicina tradicional e do pré-natal indígena}

Os discursos dos indígenas que participaram dos encontros entre parteiras, pajés e agentes indígenas de saúde evidenciaram que grande parte dos saberes e das práticas relativas aos cuidados com a gestação e o parto são difusos e compartilhados pelos integrantes de uma dada comunidade. Esses cuidados mobilizam não só os cuidadores da saúde que atuam como 'especialistas'- xamãs, parteiras e agentes indígenas de saúde (AISs) -, mas também os familiares e parentes mais próximos da gestante. Alguns desses cuidados são de responsabilidade das próprias gestantes e de seus familiares, sem que haja a necessidade de se recorrer à intervenção especializada, mas outros só podem ser ministrados pelos pajés ou pelas parteiras. Além disso, a possibilidade de se responsabilizar por essas práticas é condicionada pelo gênero do cuidador indígena: ao passo que umas são de domínio exclusivo das mulheres, outras devem ser realizadas somente por homens situados na rede de parentesco da gestante.

Há um amplo e complexo conjunto de condutas, técnicas e recursos utilizados pelas comunidades indígenas do Alto Juruá nos cuidados com a gestação e o parto que pode ser compreendido como práticas de autoatenção (Menéndez, 2003). Essas práticas contribuem não só para garantir uma gestação tranquila e um bom parto, no sentido estrito, mas também fazem parte dos processos socioculturais de produção de pessoas aparentadas e de corpos, aqui concebidos como um conjunto de afecções ou modos de ser que constituem um habitus (Viveiros de Castro, 1996). Acredito que os enunciados dos participantes indígenas dos encontros do Alto Juruá sobre os cuidados com a gestação e o parto são expressivos das teorias de corporalidade vigentes entre os povos pano e informados pelo idioma de substancialidade, que instrumentaliza as relações entre parentes no processo de construção de corpos e produçáo de pessoas aparentadas e engendradas.

Por isso, colocam-se em diálogo os depoimentos prestados nesses eventos e as informações etnológicas produzidas por Lagrou (2007) sobre os Kaxinawa, de modo a auxiliar a compreensão das lógicas socioculturais particulares que organizam a interação entre parentes durante o empreendimento gestacional e no momento do nascimento. Mesmo que se refiram a um povo indígena particular, 
os dados apresentados pelo autor podem, em virtude uma possível unidade cultural, lançar luz sobre os discursos dos outros participantes pano que estiveram presentes nesses encontros. A escolha pelos Kaxinawa deveu-se a dois fatores: o primeiro diz respeito ao fato de a maioria dos participantes desses eventos pertencerem a esse povo, até mesmo por eles terem o maior contingente populacional nessa região; o outro se refere ao fato de esses estudos etnológicos serem os mais abundantes entre os povos pano.

Entre os cuidados com a gestação e o parto mencionados pelos participantes dos encontros do Alto Juruá, estão as dietas alimentares a serem observadas pela gestante e seu cônjuge e, às vezes, por toda a família; o uso de "folhas" e de "remédios da mata", feitos à base de plantas ou de animais para preparar um bom parto e desenvolver certas habilidades nas crianças; e as rezas empregadas para intervir em complicações que possam ocorrer nesse processo. Para se referir a esse conjunto de práticas indígenas utilizadas durante a gestação e o parto, os participantes dos encontros do Alto Juruá empregaram, de acordo com o contexto discursivo, as categorias de "medicina tradicional" e de "pré-natal tradicional ou indígena".

\section{Medicina tradicional indígena como categoria discursiva}

A categoria medicina tradicional indígena irrompeu em meio aos discursos proferidos nos encontros entre parteiras, pajés e AISs quando se conversava sobre temas associados aos cuidados com a gestação e o parto. Os enunciados revelaram que são múltiplos os sentidos atribuídos a essa categoria pelos participantes desses eventos, e alguns deles emergiram no próprio processo dialógico estabelecido. Como variações da noção de medicina tradicional, os indígenas do Alto Juruá usaram as expressões "medicina natural", "medicina da mata", "medicina da floresta", "ervas medicina", "erva tradicional", "medicação tradicional", "remédios tradicionais", "remédios da mata", "ciência tradicional", "conhecimento tradicional" e até mesmo "pajelança".

Geralmente, os sentidos vinculados à medicina tradicional dizem respeito aos remédios feitos à base de plantas - as "folhas". Os participantes entendem que o uso das folhas e dos remédios da mata faz parte da cultura e da tradição de cada povo representado nesses eventos. Em alguns casos, as próprias plantas foram qualificadas como tradicionais. Na medida em que vida e tradição se confundem, o tradicional acaba por se tornar um atributo inerente às próprias plantas que, ao serem compreendidas como medicina, também exercem agência quando utilizadas para prevenir e tratar doenças. 
A partir do momento em que nós começar a usar, ela começa a aparecer pra nós, ela começa a chegar perto de nós, porque ali nós estamos juntos com aquelas medicinas e aquelas medicinas tão junto de nós. (...) As coisas tradicionais também têm sua vez. (AIS kaxinawa)

Os discursos veiculados durante os encontros demonstram o quanto a reflexão sobre a importância do uso das plantas medicinais já vem ocorrendo em algumas comunidades indígenas do Alto Juruá. Esse é o caso das comunidades da TI Kaxinawa de Humaitá que, para promoverem o "renascimento das ervas medicina", criaram o agente de medicina tradicional que, além de ser o responsável por preparar e manter um horto de plantas medicinais, trata de algumas doenças com as ervas que conhece.

Eu quero falar um pouco do trabalho que a gente vem fazendo na nossa comunidade. (...) A 'erva medicina' na minha aldeia é uma fonte que tá renascendo com muita potência. Inclusive, a gente já tem também uma área plantada. (...) Porque a gente veio vendo, analisando que a parte da nossa cultura tava um pouco esquecida. As pessoas não estavam ligando mais pra parte da erva. Então, com o estudo da natureza a gente descobriu que isso era uma fonte muito importante. Aí, a gente criou essa área! (...) As pessoas que trabalham com a 'erva medicina' nós chamamos de agente de medicina tradicional (AIS kaxinawa).

Então, lá na minha aldeia eu sou agente de medicina tradicional. Durante quatro anos eu pesquisei com meu pai, com minha tia, e já dá pra mim trabalhar pra curar algum sintoma de doença dentro da comunidade. (...) Eu venho trabalhando ao lado da minha tia para curar qualquer sintoma de doença que aparece dentro da comunidade. (...) No caso de nós não puder resolver na aldeia, tem a nossa AIS que é pra resolver na parte do nawa. (Agente de medicina tradicional kaxinawa)

A experiência de Humaitá estimulou um kaxinawa do Caucho a aprender sobre as "ervas medicina" com os mais velhos e a plantá-las em sua comunidade. Com aquilo que aprendeu junto a seus parentes e em suas pesquisas, ele também atende às pessoas que o procuram. "Aqueles que não têm vergonha e me procuram, eu tô à disposição pra atender. Eu tenho essas mudas lá já plantadas (...) e meu sonho é cada vez aumentar mais e não diminuir" (AIS kaxinawa).

Pelo visto, as iniciativas locais de promoção da medicina tradicional estão cada vez mais difundidas entre os povos indígenas do Alto Juruá. Talvez esse seja um aspecto do fenômeno de "revitalização cultural" (Olhar Etnográfico, 2006b) atualmente vivenciado por esses povos. Se assim for, esse fenômeno vem contribuindo para a emergência de outras posições sociais nas comunidades indígenas, como é o caso do agente de medicina tradicional kaxinawa. 
Mas a medicina tradicional também é compreendida por alguns participantes como uma atribuição dos pajés. "Ele tava falando o pensamento dele sobre a medicina tradicional. É assim: do jeito que tem os médicos na cidade, tem os pajé que sabem de medicina. Ele falou que os pajés também são os médicos das comunidades lá na sua aldeia" (AIS traduz a fala de um pajé). Os pajés são reconhecidos por saberem sobre os remédios da mata, pois são eles que dominam a ciência tradicional.

O pajé conhece da medicina tradicional, como também a prevenção. Antes de acontecer tem que prevenir, né? A mulher quando é grávida, no primeiro mês, vai tirando remédio da mata até nascer. Quando nasce, a gente banha até crescer, até ser batizado e mudar o dente. Essa é a ciência tradicional dos pajés. Eu admiro muito essas coisas da tradição. (AIS kaxinawa)

Outro pajé kaxinawa, igualmente, chegou a afirmar que, com o seu conhecimento sobre as "ervas medicinas", ele pode ajudar as mulheres a se recuperarem rapidamente após o parto. As folhas e outros remédios da mata utilizados pelos pajés também compõem um tipo de "kit do índio". O problema é que, atualmente, nem sempre as plantas utilizadas como remédios tradicionais estão acessíveis às comunidades indígenas.

Eu, como Huni Kuin, tenho orgulho de dizer que eu não sei de tudo... Tô aqui pra aprender! Por isso tô aqui! Por mais que eu não vou ser parteiro, como seria a mulher, mas posso ajudar. Como? Com ervas medicinais! Qual o tipo? Se precisar de um cozimento pra desinflamar, por exemplo: nasceu bebê ontem bem cedo, então, à tarde a gente vai pegar uma erva medicinal, põe pra amornar na água, mais tarde dá um banho. Com três, quatro dias, tá desinflamando toda a mulher que deu à luz. Isso é um tipo de kit do índio! Não é só o branco que tem kit, não! O pajé também tem! Nós temos! (...) O que nós precisamos é do kit do pajé: traga essa compressa pra desinflamar, traga a cera do mel de abelha pra colocar na coroa da criança pra não pegar quebrante, vento caído. Nós, Huni Kuin Kaxinawa! (...) Hoje tamo querendo só do branco: gilete, guarda-chuva, lanterna... Não precisa! Se precisasse de lanterna nós não era nascido! Eu não tava aqui conversando! E tem o nosso kit do índio: óleo de copaíba pra passar na moleira pra não tomar susto, não dá agonia, ataque, alguma coisa... Pega um remédio e bota nos olhos quando o bebê nasce, o sumo de uma folhinha, pra que o espírito (yuxin) não assombre a criança, fazendo careta pra ela tomar susto! Kueeeeee, kueeee, kueee! Já foi a alma (yuxin) da criança! Então, pra não dá aquilo, pra não dormir ruim, pra não levar maldade, pega o remédio, abre o olho do bebezinho e coloca um pinguinho. Ele vai sentir um pouquinho, vai chorar, vai doer, mas aquilo vai preservar o espírito dele pra não ser carregado! Na hora que nasce a criança, às vezes tem um espírito adiantado que também quer ser parteira! Quer pegar a alma do bebê e levar! Muitas das vezes o bebê com dois, 
três dias chora, chora e morre! Aí, diz que o espírito carregou! Mas eu não sou realmente pajé espiritivo!

Contudo, apesar de os pajés serem reconhecidos como grandes sabedores da ciência da mata, há conhecimentos sobre as plantas que também são difundidos entre as famílias indígenas do Alto Juruá.

Quando existe problema de doença na aldeia, que depende da medicina, às vezes procuram o pajé. Mas muitas famílias conhecem um pouco dessa medicina. Então, não depende quase de ir atrás de um profissional como o pajé, porque quase toda a família tem um pouco de conhecimento. Quando a mulher ganha o bebê, os pais mesmo se dividem pra fazer aquele tipo de prevenção, como falam. O posto de saúde tem a vacina pra evitar certas doenças; tem a mesma coisa na tradição. (AIS kaxinawa)

Para enfrentar as doenças, percebidas como espíritos - yuxin-que, na sua agência entram no corpo da pessoa, os Kaxinawa utilizam uma série de recursos. As influências nocivas que os yuxin exercem sobre os recém-nascidos levando-os a adoecer, como no caso em que o yuxin quer levar a alma do recém-nascido aqui descrito pelo pajé, são neutralizadas pela queima de ervas aromáticas dentro da rede, pelos banhos à base de plantas e pela aplicação do sumo de determinadas folhas nos olhos da criança. A maior parte das plantas usadas no banho medicinal tem a propriedade de tornar a criança invisível aos olhos do agente causador da doença (Lagrou, 2007).

Coletei vários exemplos de doenças tratadas com 'folhas do mato' (...) causadas pelos yuxin: quando uma criança chora muito de noite, entende-se que um yuxin está tentando levar sua alma, nesse caso folhas são queimadas para afastar os yuxin; quando uma pessoa é pega pelos yuxin, será com plantas medicinais espremidas nos olhos que ela será trazida de volta à vida normal; e se os yuxin da caça vêm, não para roubar a alma, mas para transformar o corpo da vítima em um deles, será novamente com plantas que os humanos os combaterão. (Lagrou, 2007: 399)

Durante os encontros de parteiras, pajés e AISs que aconteceram na aldeia do Caucho, em Tarauacá, os Katukina da aldeia Sete Estrelas apresentaram outro ponto de vista: eles não conheciam aquilo que os parentes indígenas chamavam de "medicina da mata" e contaram que em sua aldeia as doenças eram curadas somente pelas rezas do pajé.

Eu vou falar um pouco aqui pros meus parentes. Tô participando nessa oficina muito maravilhosa, mas só que eu tô um pouco vergonhoso. Por quê? Porque eu tô vendo os meus parentes falar um pouco de medicina - o pouco que eu tô 
entendendo - e nós não sabe esse negócio de medicina. Nenhum de nós entende o que é medicina da mata pra curar doença. A doença que nós cura é através de reza de pajé! (...) Na parte da mulher, nós não tem as folhas pra dar pra ela. Quando a mulher ganha neném nós faz só na reza dos pajés mesmo, pra aquela mulher ganhar neném em paz. Nossa realidade é essa. Só isso que eu queria dizer. (Cacique katukina)

\section{A medicina tradicional em diálogo}

No fluir do diálogo que aconteceu durante no encontro da Aldeia Morada Nova, município de Feijó, os sentidos atribuídos à medicina tradicional indígena foram emergindo à medida que as pessoas se manifestavam. Um AIS kaxinawa disse entender a medicina tradicional como a ciência advinda da cultura antiga de cada um dos povos indígenas ali representados. Nesse contexto de fala, a ciência aparece como sinônimo dos conhecimentos de domínio dos pajés e das parteiras.

O que eu entendo como medicina tradicional é a ciência que cada povo indígena tem desde a cultura antiga que eles vêm preservando. É essa ciência relacionada ao pajé è̀ parteira. A medicina tradicional envolve o trabalho desse pessoal. Então, é uma ciência, é um conhecimento que nós temos muito rico na nossa aldeia. o que eu entendo como medicina tradicional é isso aí. (AIS kaxinawa)

Diante dessa colocação, algumas anciãs indígenas perguntaram para os demais participantes se o conhecimento de "fazer a mulher ganhar neném" se constituía em uma ciência e se, neste caso, o conhecimento de todas elas e dos pajés formava a medicina tradicional.

Elas vieram me perguntar se era mais ou menos assim: isso aqui é uma ciência, no pensamento delas, só de fazer a mulher ganhar neném. Essa daqui sabe tratar dor na barriga, ela esfrega tua barriga até você ficar bom. Ela disse que tá pensando que isso aí é outra ciência que ela tem. Outra medicina que ela usa. Ela disse que quando uma pessoa tá com dor na cabeça e ela não sabe o remédio, aí ela vai na mata e busca outro. Ela diz assim: 'eu acho que dá pra fazer outro tipo de remédio'. 'Será que juntando os conhecimentos da gente forma a nossa medicina tradicional?'. Elas tão perguntando. (AIS kaxinawa)

Valendo-se do conhecimento em construção baseado no diálogo sobre medicina tradicional, as anciãs tentavam adaptar as novas informações à sua experiência. Em seu ponto de vista, cada conhecimento aplicado a fim de intervir em situações específicas representava uma ciência - para fazer a mulher ganhar neném é uma; para tratar dor de barriga é outra. Além disso, cada pessoa detinha conhecimentos diferentes entre si, ou seja, apresentava uma ciência particular e 
trabalhava com uma medicina específica. Sustentada sobre essa lógica, a medicina tradicional, então, se constituiria no conjunto desses conhecimentos e práticas.

A fala das anciãs também evidenciou o caráter experimental dos saberes e das práticas tradicionais de cuidados com a saúde. A todo o momento, em razão das necessidades de saúde, as pessoas fazem novos experimentos tentando tratar e curar as doenças que aparecem em seu cotidiano. Nesse processo, os conhecimentos são permanentemente atualizados, o que demonstra o caráter dinâmico da tradição como entendida pelos indígenas.

Por outro lado, os saberes especializados são de domínios de pessoas particulares, pois são obtidos nas experiências vividas no decorrer de suas trajetórias, ao passo que os compartilhados são aqueles de domínio familiar e comunitário. Cada 'especialista' teria um saber único, composto por conhecimentos não compartilhados com nenhum outro especialista, ainda que classificados sob um mesmo rótulo (pajé, parteira), e também um saber comum, compartilhado não só com outros especialistas, mas também com a comunidade como um todo.

Para contribuir com o debate instaurado, um AIS kaxinawa ampliou a definição de medicina tradicional a fim de abarcar o conhecimento sobre o solo, a floresta, a água e os animais, porque esses elementos são utilizadas pelas pessoas para fazerem a sua ciência. Dessa maneira, a medicina tradicional se constituiria em um conhecimento natural e também um saber prático.

Quando se fala da medicina tradicional que vocês colocaram aqui, era isso: a nossa medicina tradicional era todo o conhecimento de um aos outros, dos nossos antepassados, que eles colocavam a sua ideia na questão do solo, da floresta, dos líquidos que é a água. Tudo um pouco disso aí, nossos animais, tudo é medicina tradicional, porque alguma coisa desses objetos você usa na sua ciência, nos seus costumes, nos seus ritmos, pra fazer uma medicina daquilo ali. Então, é um conhecimento mesmo natural, que traz alegria pra todo mundo na hora que você consegue aquilo. (...) Na questão das presas dos animais, da queixada, você toma um chá e ele não te prejudica, você fica mais saudável ainda! Então, a medicina tradicional é o conhecimento de cada um aqui, a troca de experiência, de cada um aqui vai enriquecer os conhecimentos de cada um e levar pra sua comunidade. E tentar fazer isso, pra não depender de dizer: 'Bom, melhorou o quê na questão das parteiras?'. 'Ah, melhorou porque veio tesoura'. (...) Isso não melhorou, não! Isso até contribuiu com uma coisa talvez diferente: aprendemos um pouco da técnica, mas a prática é o mais importante! Eu acho que hoje não são os objetos, os materiais que vão melhorar, que vão fortalecer. Eu acho que é a prática disso que a gente não pode perder! Isso que é o melhor! Então, é por isso que hoje a gente tá caindo nessa dependência do branco, por que: 'Ah, nós só vamos ser parteira se temos o kit!'. Então, ouvi ali a parteira falando que ela tem um certificado de parteira, mas não tem o kit. Talvez ela seja melhor parteira tradicional do que as outras que tão confiando nos seus kits. Só vai cuidar se tem o kit? Às vezes, 
pode ser uma coisa que vai falhar ali. Então, a melhor coisa no seu trabalho é a sua boa vontade, o seu interesse, o seu conhecimento. Ali que vai fazer tudo se transformar na nossa medicina, na boa vontade, em tudo o que a população vai sentir agradável. Muitas vezes quando a gente fala de projeto, o parente pensa 'Ah, é dinheiro!'. Projeto, ninguém faz sem dinheiro! Mas projeto é quando você se planeja pra trabalhar e garantir aquilo quanto tempo puder. É um projeto de vida! Tudo isso aqui é nossa medicina! Tudo o quanto você pensar da sua ciência, da sua sabedoria, ela pode ser uma medicina. Às vezes, o pessoal não acredita que uma terra dessa serve pra medicina! Serve sim! Uma água serve sim pra medicina tradicional! Roda a nossa floresta, todo e qualquer pé de árvore é uma medicina. Então, dá ânimo pra gente esses conhecimentos! (AIS kaxinawa)

Nesse processo, uma das antropólogas da equipe de execução dos eventos também se engajou nos debates acerca dos sentidos relacionados ao termo da medicina tradicional indígena. Após a reflexão proposta pelas anciãs indígenas, a antropóloga, em sua autoridade discursiva, afirmou que, para o branco, a medicina tradicional é o conhecimento de cada um, ao mesmo tempo que é o conhecimento de "todo mundo".

Para o branco, quando fala medicina tradicional, é o conhecimento dela, dela, dela, dela... De cada um! É diferente? É diferente! Mas se juntar é muito conhecimento! Se juntar é muito! Então, quando a gente tá falando de medicina tradicional, tá falando de todo mundo. Um conhece remédio pra uma coisa, outro pra outra, uma sabe mexer quando a mulher tá tendo o neném de um jeito, outra sabe de outro. Tudo isso é o que a gente considera, e que o branco considera medicina tradicional!(...) Então, eu acho que é importante pensar que a medicina tradicional não é só a planta. É o pensamento, é o conhecimento de cada um. É muito mais do que planta. É diferente do branco. Branco pensa muito em remédio e eu acho que, quando a gente pensa medicina tradicional, tá pensando em tudo isso. O conhecimento de todo mundo, o pensamento de todo mundo. O que aprendeu, o que foi repassado pela avó que passou pra filha, que passou pra neta. É isso que a gente tá falando quando fala em medicina tradicional.

Assim, o caráter de ciência atribuído à medicina tradicional emergiu durante o processo dialógico propiciado pelos encontros no Alto Juruá a partir da própria reflexão acerca do tema realizada por seus participantes. Nesse caso, o antropólogo se engajou no debate contribuindo para a construção de um consenso situacional sobre a noção de medicina tradicional indígena. Digo situacional porque, por meio do diálogo, os participantes do encontro da Morada Nova estabeleceram um consenso sobre os sentidos que informam a noção de medicina tradicional. Mas, na verdade, esses sentidos são constantemente reinventados cada vez que pautados em um processo comunicativo dinâmico e criativo como aquele que aconteceu nos encontros de parteiras, pajés e AISs. 
Ao se deter sobre os discursos dos participantes dos eventos comunicativos que aconteceram no Alto Juruá, percebe-se que a concepção de medicina tradicional se apresenta como um código. A esse código estão vinculados múltiplos sentidos, os quais só são desvelados quando se consideram as relações que ele mantém com outras categorias simbólicas, às quais a MT está associada. Para apreender e compreender esses múltiplos sentidos, é necessário considerar o contexto discursivo em que essas categorias são acessadas. Dessa forma, outra dimensão significativa da medicina tradicional emerge quando nos debruçamos sobre a categoria discursiva "pré-natal indígena" ou "pré-natal tradicional" utilizada pelos participantes dos encontros ao se referirem aos cuidados tomados na comunidade durante o período da gestação.

\section{Dietas, condutas e remédios do mato: a emergência do pré-natal indígena}

Os povos indígenas representados nas reuniões de parteiras, pajés e AISs realizam uma série de práticas de autoatenção durante a gravidez que também podem ser englobadas pela categoria 'medicina tradicional'. Além do uso das folhas e dos remédios feitos à base de plantas, os participantes dos encontros ainda mencionaram o uso de substâncias animais e das dietas que precisam ser realizadas durante a gravidez para garantir um bom parto.

Uma das práticas amplamente difundidas entre os povos pano é o uso de uma substância exsudada pelo sapo chamado kampô (Phyllomedusa bicolor). As pessoas aplicam essa substância sobre queimaduras superficiais nos braços ou nas pernas, por isso é conhecida também como "vacina do sapo" ou "injeções de kampô". "As 'injeções de kampố são usadas principalmente pelos homens para melhorar suas capacidades cinegéticas e eliminar a preguiça. (...) As mulheres usam o kampô durante a gravidez para ficarem fortes e para que as crianças nasçam sadias" (Instituto Olhar Etnográfico, 2006b: 79).

O uso do kampô foi apresentado pelos Katukina durante os encontros do Alto Juruá como uma prática que faz parte do seu arcabouço cultural. "Pra nós, isso é da cultura mesmo. Vem de muito tempo atrás, de nossos antigos o negócio do kampô. (...) Isso é a nossa cultura, a cultura dos índios katukina! Antes de ganhar neném, sempre a mulher grávida tem o direito de tomar o kampô" (Pajé katukina). Os Katukina explicaram que as grávidas aplicam o kampô para diminuir os enjoos, o cansaço, a fraqueza e a preguiça. Ele também é usado para preparar um bom parto, prevenir certas doenças e promover a saúde da criança. As mulheres tomam kampô "pra ficar forte e continuar trabalhando: lavar roupa e buscar macaxeira no roçado" (Parteira katukina). Os Katukina explicam que antigamente eram os pajés que aplicavam o kampô, mas atualmente qualquer pessoa pode fazê-lo. ${ }^{1}$ 
Outra prática de autoatenção utilizada pelos povos indígenas representados nos encontros no Alto Juruá são as dietas alimentares que devem ser observadas pelos casais durante a gestação. Há alimentos que, ao serem consumidos, podem trazer prejuízos à gestação ou ao parto, ou mesmo causar doenças no recém-nascido. Outros são recomendados para esse período por promoverem uma boa gravidez e um bom parto, preservarem a saúde da grávida e desenvolverem certas capacidades na criança.

Por isso, a parteira jaminawa-arara aconselha as gestantes de sua aldeia a não comerem tatu para que não tenham dificuldade em parir, já que é difícil arrancá-lo de sua toca. Ao mesmo tempo, recomenda a cabeça de paca, porque esse animal, "ao suspirar de uma só vez" ajuda o neném a nascer rapidamente.

Eu não dou não dou tatu pra ela comer porque faz mal. Pra gente arrancar o tatu da toca faz força, né? Aí dificulta pra criança nascer também. Tatu eu não deixo comer! Paca eu dou a cabeça porque o meu pai dizia que quando ela suspira é de uma vez só. Igual quando o neném nasce: é de uma vez também. (Parteira jaminawa-arara)

Enquanto a mulher está grávida, os Katukina recomendam ao casal se abster de alimentos - caças, peixes e frutas - que podem trazer sofrimento para a parturiente e dificultar o nascimento da criança. Por exemplo, se a grávida comer jabuti, a criança ficará pregada no seu útero, da mesma forma que a carne do jabuti é presa ao casco. Quando acontece de a gestante ou seu marido ingerir algum alimento não recomendado, o pajé precisa rezar.

Mulher grávida não pode comer jabuti, jacaré, arraia, bodó e também algumas frutas. Mulher grávida não pode comer para não sofrer no parto. Ela sofre e não ganha. Daí, pra ganhar, o pajé tem que rezar a comida que ela comeu. Aí ela ganha. Se não rezar também, só operando. É assim que faz. Eu também sou pajé. (AIS katukina)

Os Kaxinawa também mencionaram a importância das dietas durante a gestação como medida para evitar problemas no parto e o adoecimento da mulher e do recém-nascido. Um pajé huni kuin apresenta explicações mais detalhadas sobre os motivos que fazem da dieta uma prática de saúde importante:

As mulheres não devem comer bodó (peixe), porque é difícil pra sair do buraco: ele abre a asa, rasga tudo e quebra. Aquilo faz tipo uma hemorragia e leva a morte no parto! Não sai o bebê! Quer sair de qualquer maneira, atravessado. (...) Essa é a dieta dos indígenas. Não pode comer jabuti, que dá hemorragia: você quebra um jabuti e ele sangra bastante. Assim diziam os anteriores, os meus avós. (...) E outro, tem bicho que come - bodó, paca de rabo arraia e outros -e que dão problema nos restos das crianças: prega lá e muitas das vezes quando se 
leva pra cidade o nawa passa a faca. Aí precisa lutar: embora, põe a luva na mão, mete dentro! Isso pode prejudicar! Eu ouvi aqui, sobre aquele remédio que toma durante nove meses pra despachar. Então, você tomando aquele remédio, é um tipo de pré-natal! Com isso resolve tudo. Não precisa nem tocar com a mão, não! A criança mesmo fica normal, no dia fica direito, muita das vezes não vai sangrar muito; muitas vezes não vai dar muita dor. Quando sentir, vai e ganha logo. Já fica preparado olhando as matas pra correr lá e despachar. (Pajé kaxinawa)

Ao garantirem o crescimento corporal bem-sucedido do novo ser que está sendo gerado, as dietas remetem à definição social do corpo kaxinawa, concebido como "pessoa estendida", por incluir "seus parentes próximos, pessoas que viveram juntas por muito tempo, que se alimentaram e foram alimentadas umas pelas outras" (Lagrou, 2007: 328). É justamente por fazer parte de um mesmo "corpo estendido" que o casal está sujeito a inúmeras dietas e cuidados durante a gestação e após o parto.

Os pais do ser que está sendo gerado, por isso, devem evitar uma série de alimentos e condutas, de modo a não prejudicar a saúde da criança, nem comprometer o parto. Para prevenir doenças causadas pela quebra das dietas, os pais e os avós orientam as grávidas e seus cônjuges sobre os alimentos que devem ser evitados durante a gestação para que a criança não seja acometida por 'ataques' e nasça deficiente.

Então, o povo kaxinawa é a mesma coisa que as Katukina falaram. Na gravidez, tem o acompanhamento dos pais e dos avós sobre a comida. (...) Quando a mulher engravida não pode comer muita coisa para a criança não ter aquele ataque que nós chamamos dubaichedyke! Quando dá aquele ataque, a criança trinca os dentes e fica babando. Pra criança não nascer deficiente e ficar dando aquele ataque, a mulher não pode comer muita coisa. (AIS kaxinawa)

E cabe destacar, além disso, que as prescrições alimentares durante a gestação são diferentes das que devem ser observadas depois do nascimento. No primeiro caso, as atividades e a alimentação da mãe e do pai influenciam diretamente a formação do feto; no segundo, a criança passa a estar exposta não só aos fluidos corporais de seus pais, mas também a outras influências advindas de seu ambiente externo.

Vários participantes kaxinawa fizeram menção às doenças, tais como tremedeiras, ataques e frioso, que acometem as crianças em razão de seus pais não terem observado as dietas recomendadas para o período da gestação e do pós-parto. "Porque, se come poraquê quando tá grávida, a criança fica tremendo; aquele frioso chega muito" (AIS-pajé kaxinawa). Quando a criança adoece em função de os pais não terem observado as dietas prescritas para o período da gestação ou do pós-parto, serão os movimentos do seu corpo e a sua expressão facial enquanto dorme que indicarão a origem do padecimento. 
Enquanto dorme, o bebê, cujos pais comeram da carne destes animais específicos durante o período da gestação, temporariamente 'torna-se' (...) o filho do animal que envia a doença. Convulsões e espasmos noturnos que se apoderam da vítima são designados yawabake, filhote de queixada, xinubake, filhote de macaco-prego, ou amenbake, filhote de capivara; citamos apenas os mais comuns e os mais violentos. (Lagrou, 2007: 355-356)

Na explicação de um pajé kaxinawa, alguns bichos não devem ser comidos justamente por apresentarem masná, um atributo de feiticeiros que também os torna pajés. Se a carne de um desses "animais mandingueiros" for ingerida durante a gestação, o seu espírito (yuxin) se vingará. ${ }^{2}$ Essa vingança recairá não diretamente na pessoa que o matou, mas sobre seus parentes próximos, principalmente quando passam por transformações físicas e sociais que os tornam especialmente vulneráveis, como é o caso do período da gravidez.

Enquanto tá grávida, não pode comer esses bichos porque, diziam os nossos antigos, eles têm masná. Masná é uma coisa de mandingueiro: ele é um animal, mas é pajé também. Ele gosta de vingança! A traíra gosta de vingança! Que vingança é essa? Se você come a traíra, a traíra tem um espírito mal. Todos os objetos têm o seu espírito mal e têm a alma que nasce com ele - tem os dois! A sua alma não pode sair do seu corpo; o espírito que você nasceu com ele, que é um anjo, não pode sair do seu corpo! Agora sai a alma da gente. Porque se sai o espírito, você já foi! É igual coração! Agora a alma que o espírito carrega é outra! Aquele é que faz a gente se perder! É um espírito adiantado, né?! Então, essa dieta é por aí. (...) Quando a mãe tá grávida não come dente de siri, caranguejo. (...) Ele é perigoso, é mandingueiro! Se você faz mal pra ele, ele se vinga na hora. Não vinga em você, nem em seu marido, mas vinga no filho ou no neto. De qualquer maneira ele faz a parte dele. (...) Quem diz isso são os pajés antigos! Não sou eu que tô dizendo, apenas sou terceira palavra! Ninguém deve duvidar! Essa parte que eu quero dizer. (Pajé kaxinawa)

Nesse caso, as dietas são fundamentais para proteger a saúde dos pais e da criança, porque há determinados animais com yuxin que, ao serem caçados, podem querer se vingar diretamente ou por meio dos seus familiares, daqueles que tenham ingerido a sua carne. $\mathrm{O}$ animal executa sua vingança atacando os humanos justamente no momento em que o seu yuxin se desprende do corpo. "Uma vez que perdeu seu corpo, está livre para assombrar o matador ou aquele que comeu de sua carne através de imagens que, como 'duplos' de um corpo morto, têm intenções de vingança" (Lagrou, 2007: 348). Mas não são todos os animais que realizam vingança póstuma, somente os que possuem yuxin.

Os animais caracterizados pela possessão do yuxin com a capacidade de se vingar sem usar o corpo pertencem à classe de seres com duplo, e somente esses 
seres são descritos como tendo yuxin. Estes seres são capazes de se vingar dos humanos, o que significa que se tornam como humanos. Vingança implica agência e intencionalidade, características da ação humana. Neste sentido, o que era ou parecia ser não mais que uma caça passiva pode transformar-se em um real inimigo. A vingança potencial de determinados animais, através da transmissão de doenças para parentes próximos do ofensor, é revelada para a consciência através da sua aparição em forma humana nos sonhos e visões. (Lagrou, 2007: 354)

As crianças, em razão de terem corpos fracos, e de suas almas ainda não terem se fixado em seus corpos, estão "especialmente expostas às chamadas noturnas do yuxin; os bebês assustados pelo yuxin têm, em geral, febre alta e choram a noite toda" (Lagrou, 2007: 305).

Portanto, a doença causada pela quebra da dieta pode acontecer tanto em virtude da vingança do espírito do animal caçado como pela transmissão das características de determinados animais ou plantas para a pessoa que os ingeriu (Lagrou, 2007: 223). No último caso, a lógica que informa a prática da dieta é a da semelhança. Por exemplo: o fato de o jabuti sangrar demais ao ser morto leva a mulher a ter hemorragia na hora do parto; ou, então, o fato de a anta suspirar de uma só vez faz com que a criança seja "despachada" rapidamente.

Seguindo a mesma lógica, determinadas plantas e animais são usados durante a gravidez para fazer com que suas características sejam transferidas às crianças. Isso faz com que, "dependendo da classificação de cada planta ou animal, o contato seja procurado ou evitado" (McCallum, 1999: 169).

Eis o princípio que informa o código culinário kaxinawa no qual a pessoa se torna aquilo que come. Nessa lógica culinária, "o que alguém come irá se tornar sua carne e por essa razão não se deve comer aquilo que é demasiadamente diferente de si mesmo" (Lagrou, 2007: 353). A possibilidade de se tornar outro está associada à capacidade de a pessoa acostumar o seu corpo ao modo de vida desse outro, comendo o que ele come ou mesmo o comendo. Se assim for, então, o consumo dos alimentos dos brancos também pode produzir uma transformação corporal que implica, por sua vez, uma mudança de identidade (Instituto Olhar Etnográfico, 2006b).

De primeiro o meu tio aqui era matador de caça, porque a máe e o pai dele cumpriram a dieta. Aquela comida que eles se alimentaram, fez com que ele fosse um índio marupiara, como nós chamamos, ia lá e sabia aonde tava a caça. Hoje, nossas crianças, tenho certeza que não são mais assim, como eu também não sou, matador de caça. Muitas das vezes qualquer coisinha a gente tá com raiva, critica muito os parentes. Porque o nosso pai e a nossa mãe comeram qualquer comida. Hoje nossas crianças são muito apaixonadas por futebol é porque, eu tenho certeza, nós comemos aquela alimentação que, mesmo sendo um animal da mata, pula pra aqui, pula pra acolá e aquilo vai puxando, né? (AIS kaxinawa) 


\section{O pré-natal tradicional como categoria híbrida}

No espaço formal de atenção à saúde, a assistência ao pré-natal é entendida como um conjunto de consultas e de exames executados pelos profissionais da saúde no acompanhamento das gestantes, visando a prevenir doenças e a promover uma gravidez e um parto seguros. Segundo a Organização Mundial da Saúde (OMS), "a assistência pré-natal é um conjunto de cuidados médicos, nutricionais, psicológicos e sociais, destinados a proteger o binômio mãe-feto durante a gravidez, parto e puerpério, tendo como principal finalidade a diminuição da morbidade e da mortalidade materna e perinatal" (Costa e Sousa, 2002: 17). Os conhecimentos biomédicos que informam a assistência ao pré-natal são, em termos epistemológicos, radicalmente diferentes dos saberes relacionados aos cuidados com a gestação entre os povos indígenas representados nos encontros que ocorreram no Alto Juruá.

Os participantes indígenas desses eventos comunicativos se apropriaram e indigenizaram a noção de pré-natal, originalmente inscrita no contexto do sistema oficial de saúde, utilizando-a para se referirem aos diferentes cuidados prestados à gestante em contextos étnico-comunitários particulares. Ao atravessar as fronteiras da diferença cultural e ser esvaziada semanticamente, a noção do pré-natal, como símbolo deslocado, surge nos discursos indígenas como a categoria híbrida "pré-natal tradicional".

Antes ninguém tinha o pré-natal. Por que a gente não tinha o pré-natal? Porque nós mesmos quando estávamos grávidas sabíamos nos cuidar. As nossas mães procuravam saber se nós tava grávida e com quantos meses. Então, se você não se cuidou, você diz pra sua mãe e a ela vai tentar tirar aquela criança pra não ficar pregada. Essa é a nossa prevenção e os nossos cuidados com a pessoa que tá grávida. Nós mesmos temos como prevenir, ajeitar o bebê pra ele nascer normal, né? Então essa que é a orientação pras grávidas do povo huni kuin. (Parteira kaxinawa)

Nos discursos veiculados nos encontros do Alto Juruá, os cuidados observados durante a gestação - a aplicação do kampô, as dietas, o uso de folhas e remédios da mata e as rezas - aparecem sob o rótulo de "pré-natal tradicional" ou "pré-natal indígena".

Muitas vezes, o pré-natal é aquilo que vocês sempre fazem: o pré-natal tradicional. Só mudou a palavra e fez com que as mulheres também procurassem o médico pra fazer o pré-natal do nawa. Mas, geralmente, o pré-natal é aquele que a gente faz quando a mulher tá com três, quatro meses: o pajé tira folha e começa a passar. Todo mundo falou que sempre passou folha. Então, eu acho que todo mundo já fazia o pré-natal tradicional. Eu fiquei preocupada porque a intenção do curso não é mudar da forma do tradicional pro técnico. Isso a gente não pode perder! Tirar o tradicional pra mudar totalmente pro nawa, né? (Liderança kaxinawa) 
O uso do termo "pré-natal" pode indicar um esforço dos participantes desses encontros em traduzir para os termos dos não índios o conjunto de cuidados indígenas com a gestação. Afinal de contas, como diz um AIS kaxinawa: "Tamo misturando nawa e nós; pra nawa entender e nós entender".

Esse é um conhecimento que a gente tem: o pré-natal indígena pra não ter muito sofrimento no parto. É por isso que nós temos nossas ervas medicinais tradicionais. A gente diz hoje que quem conhece a medicina da mata é considerado nosso médico indígena lá da comunidade. (...) A gente vai com pajé que ele entende das ervas. Nós temos o remédio da medicina da mata que podemos pegar e levar num vaso pra dar pra mulher grávida. (...) Então só isso daí. Outra coisa é não comer certos animais pra não ter problema no parto. (AIS kaxinawa)

Alguns participantes afirmaram que em suas aldeias as parteiras, os pajés e o agente de saúde atuam em conjunto para fazer o pré-natal das grávidas. Todavia, para alguns pajés kaxinawa, antigamente não existia "esse tal de pré-natal". Da mesma forma, um deles disse não saber o que significava o pré-natal por essa ser uma palavra do branco. "Falaram de dieta e de pré-natal. Eu tô imitando aqui! Porque eu nem sei o que é pré-natal!"

Anteriormente, ninguém via esse pré-natal! (...) Era um povo muito diferente e era bom! Se cuidava muito, usava os remédios e tudo. É a cultura do branco que dá o nome de pré-natal! O que faz hoje? Todos os meses quando a mulher tá grávida tem que fazer pré-natal: leva pro posto pra fazer pré-natal. Eu acho que, quando o branco criou isso, tirou muito sentido dos parentes que foram desacreditando do que nós sabíamos anteriormente e acreditando na coisa do branco! O branco tirou toda aquela sabedoria, aquele dom! Tudo o que a gente sabia, o branco foi tirando devagarzinho! (Pajé kaxinawa)

Em resposta à reflexão feita por esse pajé, outro pajé afirmou existir, sim, o pré-natal indígena, só que em vez de usar máquinas como os brancos, os índios usam a folha, a mão e o entendimento.

O nosso parente falou que não tinha pré-natal, mas índio tem pré-natal! Aquilo que fazia pra ajeitar era tipo um pré-natal. Só que do índio! O do branco tem máquina e tudo. Mas, a máquina do índio é a folha, a mão pra ajeitar e o entendimento! Então, é isso! Porque se não tivesse pré-natal indígena nós não tinham ajeitado certas coisas. (Pajé kaxinawa)

Uma situação exemplar da maneira como o hibridismo informa os discursos sobre o pré-natal tradicional ocorreu durante a reunião de Campinas, no âmbito dos grupos de trabalho organizados para abordar o papel da parteira, do pajé e do agente de saúde na assistência ao pré-natal. Importante lembrar que os participantes 
desse encontro pertenciam aos povos Arara, Jaminawa-Arara, Kaxinawa, Katukina, Nukini e Nawa, e que foi uma aldeia katukina que acolheu o evento. Os grupos de trabalho tiveram uma composição mista, na medida em que foram integrados por participantes dessas diferentes etnias.

Esses trabalhos em grupo constituíram contextos discursivos interessantes por propiciarem a emergência de enunciados sobre os cuidados com a gestação que articularam saberes provenientes de distintos horizontes socioculturais: por um lado os conhecimentos do modelo médico hegemônico disponibilizados nos cursos de aperfeiçoamento das parteiras tradicionais indígenas; por outro os saberes inscritos nos múltiplos e distintos contextos étnico-comunitários indígenas da região do Alto Juruá.

As discussões que ocorreram no âmbito desses grupos de trabalho assumiram um caráter de troca de experiências em que os saberes enraizados em múltiplos universos étnico-culturais foram compartilhados entre os seus integrantes. A própria forma como a questão foi colocada e a dinâmica de trabalho de grupo contribuíram para a emergência do pré-natal como uma categoria híbrida. É claro que os cursos de parteiras também foram fundamentais no processo de apropriação das categorias discursivas dos não índios e da sua consequente indigenização. Assim, o pré-natal tradicional constitui um pré-natal indigenizado.

A dinâmica de trabalho proposta previa que, após as discussões, os grupos de trabalho preparariam cartazes para apresentarem a síntese dos debates realizados aos demais participantes da reunião. Isso instituiu uma organização hierárquica particular ao fluxo comunicativo estabelecido entre os participantes dos grupos. Aqueles que tinham maior domínio da escrita, os AISs, acabaram por se destacar, cabendo a eles a incumbência de elaborar os cartazes com os resultados dos debates realizados. Mas os AISs não se limitaram a escrever o que os seus companheiros falavam, eles também avaliavam que conhecimentos era pertinente apresentar à grande audiência.

Na transposição das expressões orais para a escrita, os saberes e experiências de cuidados com a gestação vinculados a contextos socioculturais particulares passaram a representar os conhecimentos e experiências de todos os povos indígenas ali presentes, adquirindo status generalizado e universal. Ao serem escritos nos cartazes sem mencionar a origem étnica da informação, tais saberes foram misturados e planificados de modo a serem apresentados ao grande grupo como comuns aos povos que compuseram o grupo de trabalho. Ocorreu, nesse caso, uma transformação discursiva das falas que aconteceram nas discussões de grupo para o discurso inscrito no cartaz. Os cartazes apresentados pelos dois grupos de trabalho são expressivos desse processo: 
Cartaz do Grupo 1 - Tema: pré-natal

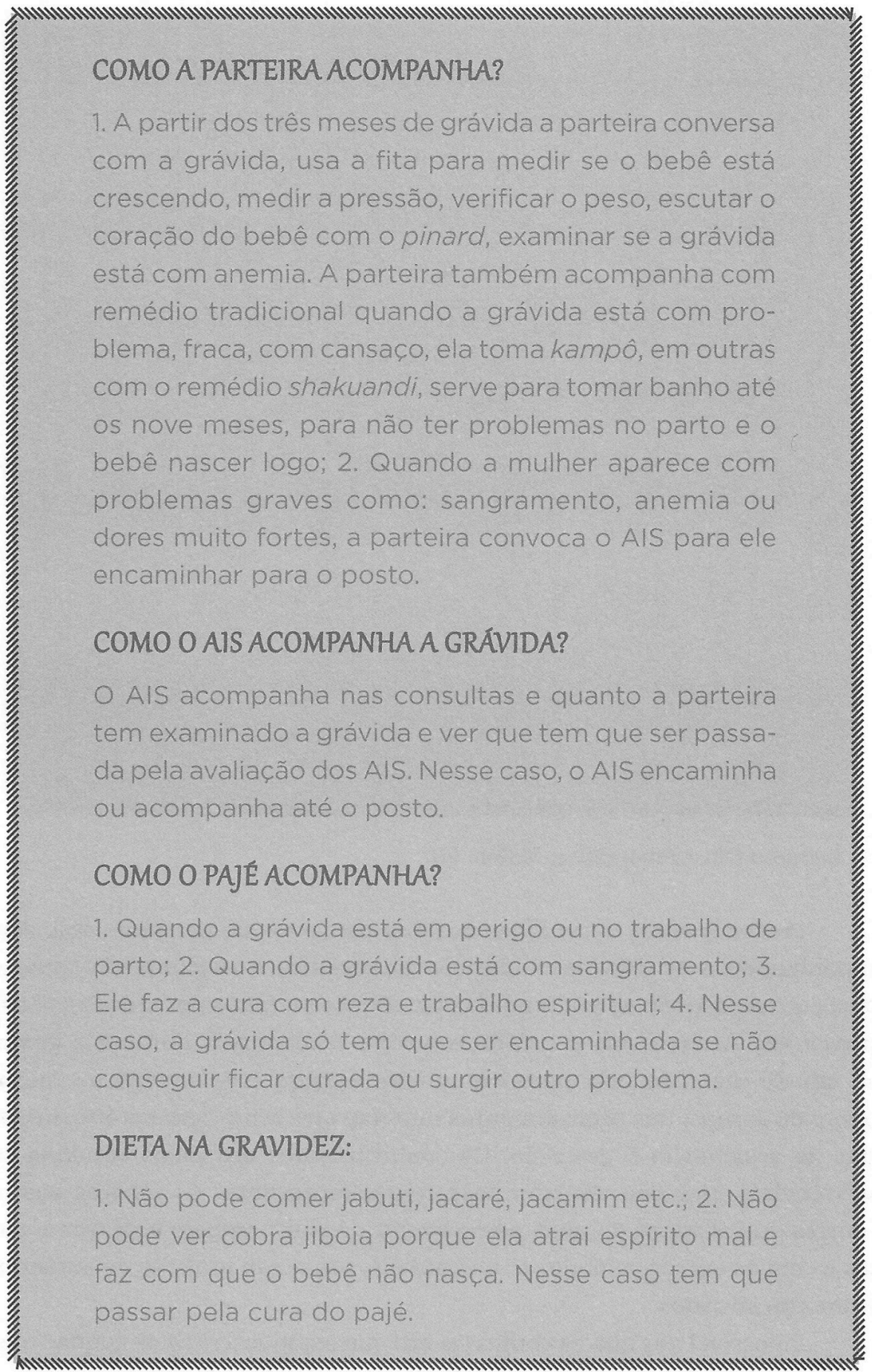


Cartaz do Grupo 2 - Tema: pré-natal

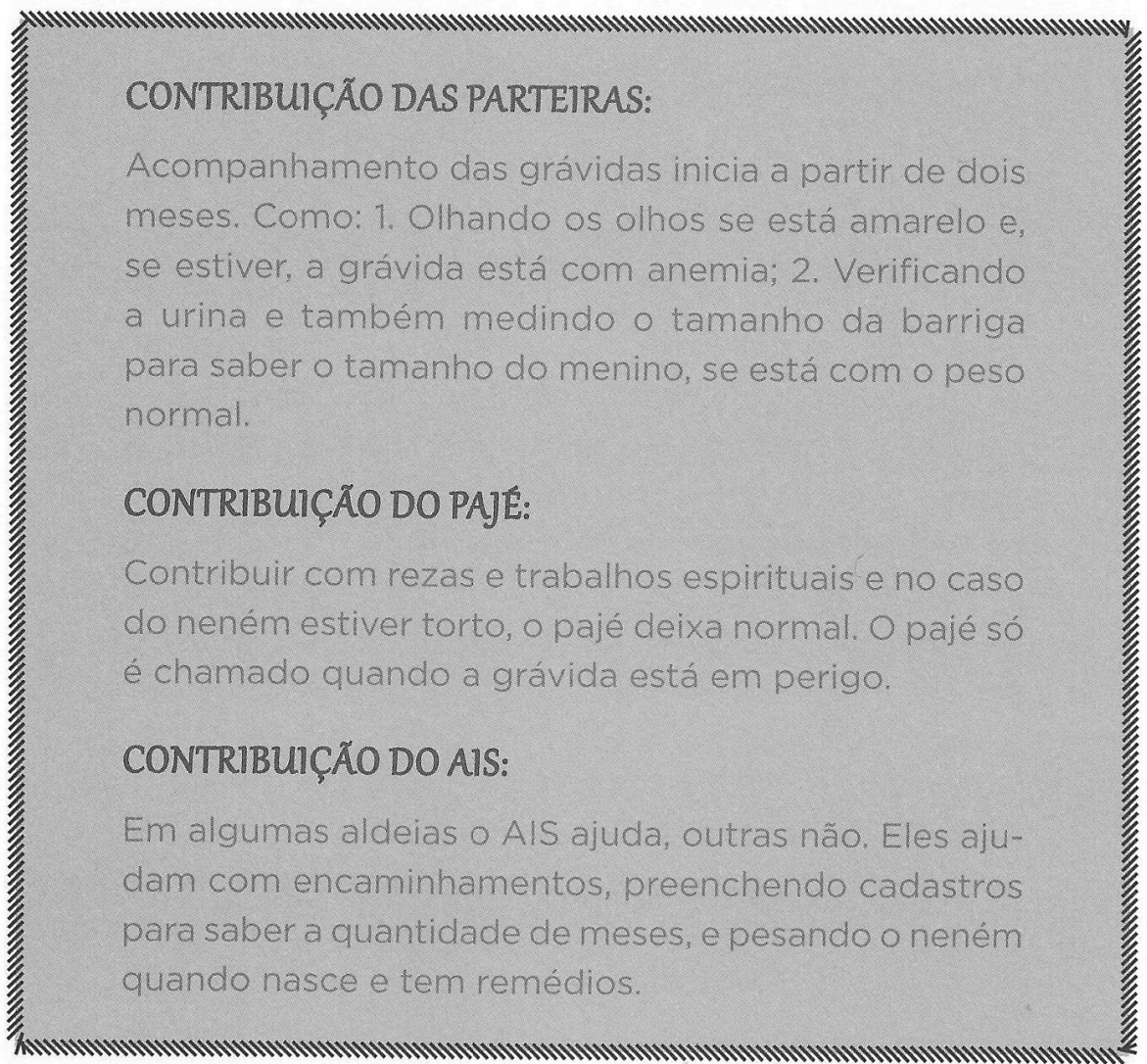

Fonte: Instituto Olhar Etnográfico, 2006a: 90.

Procedimentos aprendidos durante os cursos de parteiras, tais como o acompanhamento da grávida, a aferição da pressão, o auscultar do coração da criança com pinard são apresentados como se fossem feitos por todas as parteiras ali presentes. Assim como o uso de remédios tradicionais durante a gestação, como aquele indicado pela parteira jaminawa-arara (shakuandy) ou mesmo o emprego do kampô, tais procedimentos também aparecem como práticas comuns usadas na assistência à gestação. Os conhecimentos dos pajés katukina sobre a assistência à gestação também passaram a representar os saberes dos pajés das outras etnias representadas nesse evento. Assim também aconteceu com as dietas e com os outros cuidados e, na verdade, essas são práticas de autoatenção etnicamente situadas.

É possível ver que os contextos em que estão inscritos os conhecimentos e práticas se perderam com a elaboração dos cartazes. Isso faz com que, diante do branco, esses conhecimentos se tornem emblemas universais do conhecimento das parteiras tradicionais dos povos indígenas do Alto Juruá. Assim, a diversidade e a 
especificidade de cada um dos saberes e experiências narrados no âmbito dos grupos de trabalho são subsumidas em um discurso híbrido e, até mesmo, medicalizado.

No contexto dos trabalhos de grupo, as gestantes são transformadas em "pacientes" ou mesmo em "clientes" das parteiras. Mesmo diante dos vários depoimentos que foram prestados sobre o fato de as gestantes raramente comunicarem sobre sua gravidez no início da gestação, nos cartazes se afirma que as parteiras passam a acompanhá-las a partir do segundo ou terceiro mês de gravidez. Por sua vez, as parteiras acompanham as suas "pacientes" por meio de uma "consulta médi$\mathrm{ca}^{\prime}$, quando verificam se o olho está amarelo para diagnosticar anemia. Nesse caso, então, elas recomendam remédios da floresta e fazem um "tratamento médico". Do mesmo modo, o pajé é apresentado como "doutor da floresta", que intervém quando há algum problema durante a gestação ou no parto. Ele faz reza, cura espiritual e passa o "medicamento" adequado. Assim, podemos perceber que esses cartazes reproduzem os valores veiculados pelo sistema oficial de saúde.

Com base na análise desses cartazes e falas, pode-se perceber o quanto realidades intermédicas são elevadas ao lócus do discurso, e como os seus múltiplos sentidos são articulados nos enunciados proferidos pelos participantes dos encontros entre parteiras, pajés e AISs que aconteceram na região do Alto Juruá.

Por outro lado, os diálogos que ocorreram nesses espaços possibilitaram a reflexão sobre o valor dos saberes e práticas indígenas usados nos cuidados com a gestação. Ao considerar a troca de experiências promovida pelos grupos de trabalho como um momento de aprendizado entre os próprios parentes, os indígenas demonstraram a intenção de adotar em seu cotidiano as experiências ali compartilhadas. Assim, trocas que ocorreram entre os participantes desses encontros promovidos pelas políticas públicas tendem a influenciar o surgimento de novos saberes e práticas híbridos. Só que, nesse caso, esse hibridismo emerge nas fronteiras que demarcam as diferenças étnicas e culturais existentes entre os indígenas que estiveram representados nesses eventos emergentes. De qualquer forma, os discursos pronunciados revelam o quanto realidades intermédicas são elevadas ao lócus do discurso, e como os seus múltiplos sentidos emergiram mediante a interação entre os participantes das reuniões entre parteiras, pajés e AISs do Alto Juruá.

\section{A emergência das categorias discursivas no âmbito das reuniões do Alto Juruá}

Os enunciados dos participantes dos encontros no Alto Juruá, recorrentemente, remeteram ao que foi falado por outras pessoas em outros tempos e lugares para falarem sobre os cuidadores envolvidos e os cuidados prestados à gestação e ao parto nas comunidades indígenas ali representadas, bem como de suas relações 
com as políticas públicas implementadas na região. Eles estão repletos de ecos e reverberação de discursos proferidos em outros eventos comunicativos realizados no campo da saúde indígena. Desse modo, os princípios da dialogicidade que fundamentam os enunciados indígenas aqui considerados tendem a contribuir para a configuração de discursos híbridos.

Todavia, se os discursos proferidos durante os eventos no Alto Juruá falaram sobre os efeitos causados pela implantação de políticas públicas específicas, como as de capacitação de parteiras tradicionais, é importante dizer que sua possibilidade de existência foi dada pela irrupção de outra política pública a desenvolvida pela Área de Medicina Tradicional Indígena (AMTI). Foi ela que propiciou a criação de um espaço dialógico para tratar das articulações entre os sistemas de parto indígenas, considerados pela AMTI como um dos aspectos das medicinas tradicionais, e os serviços de saúde. Esse processo instituiu os encontros de parteiras, pajés e AISs no Alto Juruá como locais de cultura emergentes.

O fato de algumas das categorias acessadas pelos participantes nesses eventos já terem sido objeto de discursos em outras situações interétnicas instauradas pelas políticas públicas possibilitou que muitas delas fossem apropriadas tanto para nomear certas classes de agentes, contribuindo para fazê-las existir - tais como as categorias de parteira e pajé, por exemplo - quanto para classificar certos saberes e práticas indígenas sob os rótulos de medicina tradicional ou pré-natal indígena. Foi por meio dos diálogos estabelecidos no decorrer dos encontros no Alto Juruá que os significados associados aos saberes, às práticas e ao papel dos cuidadores no processo de assistência à gestação e ao parto, bem como a interação com os serviços de saúde oficiais, foram revistos e atualizados.

\section{Cultura e tradição}

Nos encontros do Alto Juruá, as noções de cultura e tradição usadas pelos indígenas para qualificar as categorias discursivas medicina tradicional e pré-natal indígena constituíram dispositivos de autorrepresentação empregados por eles para falarem de si para o outro estrangeiro, o branco. O uso de tais noções remete ao esforço comunicativo dos participantes em se fazerem compreender e reconhecer nos termos do outro. Mas elas indicam também a existência de uma 'teoria indígena sobre o branco e suas coisas' aqui compreendida como um modo culturalmente situado de perceber o outro. Portanto, tais discursos operam em um regime de etnicidade.

A teoria sobre os brancos e suas coisas emergiu nos eventos do Alto Juruá quando os participantes passaram a contrastar a forma indígena, qualificada como tradicional e/ou cultural, com a maneira do não índio de assistir a gestação e o parto. Os enunciados proferidos nesses encontros foram informados por uma série 
de contrastes relacionados à oposição fundamental nós/índios versus eles/brancos associada ao modo como esses cuidados eram realizados antigamente, e como eles acontecem atualmente no contexto das aldeias indígenas da região. Dentre as categorias contrastantes que emergiram nos discursos estão: pré-natal indígena versus pré-natal do branco; parto tradicional versus parto hospitalar; parto antigamente versus parto hoje; parteira indígena versus parteira branca (enfermeira); pajé versus médico; remédio da farmácia versus remédio do mato; medicina tradicional versus medicina do branco; conhecimento tradicional versus conhecimento do branco, entre outras.

Essas categorias mantêm entre si uma relação dialética de interdependência e ao mesmo tempo contradição, que propicia a alternância "entre duas concepções ou pontos de vista simultaneamente contraditórios e solidários entre si, operando oposições a partir de uma base comum de similaridade" (Wagner, 2010: 96). É por meio dessa relação dialética que os significados que informam os discursos indígenas foram desvelados e continuamente reinventados.

Os enunciados indígenas recorrem a uma série de analogias para traduzir um grupo de significados culturalmente situados nos termos do outro. As analogias criadas pelos participantes dos encontros do Alto Juruá, ao permitir contrastar as formas indígenas e o modo do branco de assistir a gestação e ao parto, têm a virtude de estender os significados inscritos nos horizontes socioculturais comunitários de modo a abarcar a experiência da alteridade. Assim, tais sentidos são transformados pela própria experiência de contato interétnico instituído pela irrupção das políticas públicas nas múltiplas localidades que conformam a região do Alto Juruá.

Ao empregarem a noção de cultura para distinguir as formas indígenas e os métodos do branco de cuidar da gestação e do parto, os participantes dos encontros do Alto Juruá deram visibilidade a determinados aspectos dos seus universos socioculturais, colocando em perspectiva os saberes, as práticas e os cuidadores comunitários como parte das culturas indígenas ali representadas. Esses aspectos tendem a espelhar a estrutura dos serviços oficiais de saúde prestados às comunidades indígenas da região. Segundo Carneiro da Cunha (2009), o efeito espelhamento faz parte de qualquer negociação estabelecida entre os povos indígenas e a sociedade mais ampla. Portanto, no contexto comunicativo promovido pelas políticas públicas, a categoria cultura passa, então, a ser informada pelo princípio do contraste. Nesse caso, os participantes dos encontros do Alto Juruá, portanto, fizeram um uso local da categoria cultura.

Carneiro da Cunha (2009) chama a atenção para o fato de a noção cultura ter sido fabricada nas grandes metrópoles e ter sido exportada para os países colonizados como um termo de empréstimo. 
Os povos da periferia foram levados adotá-las, do mesmo modo que foram levados a comprar mercadorias manufaturadas. (...) Num período mais recente foram os antropólogos os principais provedores da ideia de 'cultura', levando-a na bagagem e garantindo sua viagem de ida. Desde então, a 'cultura' passou a ser adotada e renovada na periferia. E tornou-se um argumento central (não só nas reivindicações de terras como em todas as demais). (Carneiro da Cunha, 2009: 312)

Portanto, a noção de cultura, em razão da própria dinâmica histórica do campo de relações interétnicas, foi apropriada e indigenizada pelos povos indígenas no Brasil, passando a ser acessada em seus discursos na luta pela sua reprodução sociocultural. No entanto, apesar de esse processo de apropriação ter se dado em. grande parte da atuação dos antropólogos, o sentido de cultura entendido pelo viés antropológico é distinto daquele operacionalizado nos discursos indígenas direcionados à sociedade ocidental. A cultura como conceito antropológico, isto é, como sistema simbólico que organiza a percepção e informa a ação das pessoas instituindo as condições para a comunicação, pertence a um universo de discurso diferente daquele acessado pelos povos indígenas onde a cultura passa a ser utilizada como argumento político. Como tal, a noção de cultura faz parte de um registro interétnico diferente daquele da vida cotidiana nas aldeias. O uso dessa categoria discursiva pelos povos indígenas no Brasil "indica que a lógica de cada um desses sistemas é distinta" (Carneiro da Cunha, 2009: 370).

Os participantes dos eventos do Alto Juruá falaram de suas culturas como importantes para a manutenção da vida e do bem-estar das comunidades indígenas. Nesse caso, a cultura está associada aos projetos de vida dos povos indígenas da região, o que acrescenta um sentido político aos múltiplos usos comunicativos que são feitos a essa categoria. Ao emergir associada a um regime de etnicidade e ser assumida de modo autoconsciente, a cultura também se torna um caminho de acesso ao reconhecimento do outro.

Assim, os povos indígenas do Alto Juruá demonstram uma autoconsciência cultural associada às demandas políticas por um maior acesso aos bens, recursos e benefícios advindos por meio da relação com o Estado. "As pessoas têm consciência da própria 'cultura', (...) além de viver na cultura" (Carneiro da Cunha, 2009: 359). Essa reflexividade, como capacidade de falar sobre sua própria fala, tem efeitos dinâmicos sobre os sentidos que a cultura assume nas situações particulares onde ela é acessada.

A esse fenômeno Sahlins (1997b: 133) chama culturalismo, uma das faces do processo de indigenização da modernidade: "O culturalismo é a formação discursiva moderna das identidades indígenas em sua relação com as alteridades globais-imperiais".

A nova autoconsciência cultural dos povos indígenas (...) está acoplada a um desejo de manter e expandir o acesso às inovações técnicas, médicas e demais 
'benefícios' materiais do sistema mundial. (...) [Os indígenas] querem englobar a ordem global em suas próprias ordens cosmológicas. (Sahlins, 1997b: 132)

Do mesmo modo, a noção de tradição, associada à categoria cultura, apareceu nos discursos indígenas qualificando algumas das categorias discursivas por eles utilizadas de modo a demarcar diferenças entre os conhecimentos e práticas empregados nos cuidados com a gestação e o parto tradicionais e aqueles identificados como provenientes do estrangeiro - do mundo do branco. Nesse caso, essa categoria também foi utilizada para contrastar diferenças e demarcar fronteiras, constituindo um meio de falar sobre si para o outro-branco. Desse modo, a tradição foi indigenizada.

Nesse caso, estaríamos diante de um processo de 'inversão da tradição', como exposto por Sahlins (1997b), por meio do qual os povos indígenas selecionam certos aspectos socioculturais como marcadores diacríticos e de autodefinição cultural "por oposição complementar aos costumes dos povos com os quais é preciso se haver. (...) Essa expressão descreve como os povos colonizados procuram se distinguir de seus senhores coloniais através da inversão das disposições habituais destes últimos" (Sahlins, 1997b: 134).

Apesar de a noção de tradição, como usada pelos indígenas, encerrar uma dimensão temporal e operar com a ideia de conhecimentos e práticas transmitidos ao longo das gerações, ela não é compreendida pelos indígenas como estática. Pelo contrário, muitos dos depoimentos demonstraram que ela é transformada por meio da agência dos praticantes das medicinas indígenas. Além disso, para alguns dos participantes dos encontros do Alto Juruá, a agência constitui um atributo da própria tradição, princípio evidenciado pelo depoimento de um AIS kaxinawa que afirma que "as coisas tradicionais também tem sua vez". Assim, o processo de produção de sentidos instituído pelo fenômeno da indigenização remete a um estilo de criatividade (Wagner, 2010) próprio aos povos indígenas que, por sua vez, é diferente daquele com o qual as políticas públicas operam. A emergência das categorias de medicina tradicional indígena ou do pré-natal tradicional nos discursos dos participantes desses eventos comunicativo expressa esse processo criativo.

\section{A emergência da medicina tradicional}

A própria noção de medicina tradicional também surgiu nos eventos comunicativos do Alto Juruá como uma categoria discursiva. Os sentidos que informam essa noção de medicina tradicional só são desvelados quando consideradas as associações que a MT mantém com outras categorias simbólicas no contexto discursivo em que são acessadas. Até porque os significados dessas categorias são produtos das associações e/ou oposições existentes entre elas inscritas em contextos particulares (Wagner, 2010). 
De qualquer forma, e sem pretender esgotar os múltiplos sentidos que informam a noção de medicina tradicional, pode-se dizer que as definições indígenas dadas a essa categoria durante os eventos do Alto Juruá foram emergentes. Em uma primeira aproximação podemos dizer que, como categoria emergente, os múltiplos sentidos que a informam nunca são plenos e tampouco fixos, permitindo que ela seja constantemente revista e recriada nas situações dialógicas que a tomam como tema. Nos encontros do Alto Juruá, essa categoria foi constantemente atualizada em um contínuo processo de autopoiesis. "A autopoiesis humana implica que no, processo de fabricação de sentido, o conhecimento é transformado, mesmo quando é mantido, e que o sentido é sempre emergente, nunca fixo" (Toren apud Lagrou, 2007: 24).

Geralmente, o sentido preponderante atribuído a essa noção foi o associado ao uso dos "remédios da mata" e suas variantes - "folhas", "ervas medicina", "medicina da mata" etc. Nesse caso, a medicina tradicional está muito mais alinhada com o sentido estrito das práticas de autoatenção por remeter as representações e práticas aplicadas intencionalmente ao processo saúde-enfermidade-atenção. Essa perspectiva pode lançar luz também sobre a compreensão que esses povos têm acerca da "medicina do branco". Na biomedicina, o medicamento talvez seja aquela parte destacável da sociedade ocidental que pode ser apropriada pelos povos indígenas de modo a assumir novos significados e usos nos contextos comunitários em que eles serão inscritos. Como vimos, a própria figura do AIS emerge como aquele que adquiriu conhecimentos sobre o "remédio dos brancos" nas relações mantidas com o mundo externo à aldeia.

Se assim for, a MT, como "remédio do mato", opera como uma imagem espelhada da biomedicina que, por sua vez, é instrumentalizada pelo dispositivo da mimese colonial. Assim, no jogo discursivo das categorias dicotômicas, a MT aparece nos discursos dos participantes das reuniões como equivalente à "medicina do branco" - símbolo autorizado do fazer saúde - e, nesses termos, as reivindicações pelo reconhecimento dos seus praticantes - parteiras e pajés - são endereçadas ao estrangeiro.

Mas, ao contemplar práticas que contribuem para a produção de corpos e pessoas indígenas, a medicina tradicional também opera com a dimensão ampla das práticas de autoatenção, pois asseguram a reprodução biossocial e cultural dos povos indígenas do Alto Juruá. Nos fluxos dos diálogos que ocorreram nos eventos comunicativos aqui considerados, alguns sentidos atribuídos à medicina tradicional remeteram à dimensão ampla das práticas de autoatenção, principalmente quando os participantes chegaram ao consenso de que a MT constitui uma ciência indígena que abarca conhecimentos sobre a vida, a natureza e o bem-estar das comunidades. 


\section{Medicina tradicional e pré-natal indígena: relações significativas e hibridismo}

Uma das dimensões significativas da medicina tradicional, todavia, foi desvelada quando associada à categoria discursiva "pré-natal indígena" ou "prénatal tradicional", utilizada pelos participantes dos encontros no Alto Juruá para se referirem aos cuidados com a gestação. Em termos analíticos, pode-se dizer que a noção de medicina tradicional engloba a de pré-natal indígena, na medida em que a primeira contempla saberes e práticas aplicados para cuidar da saúde das comunidades indígenas como um todo. A medicina tradicional também é empregada no período da gestação, mas não se restringe a ele.

Ambas as categorias são forjadas pela sociedade ocidental e, ao serem apropriadas e indigenizadas pelos povos indígenas, adquirem novos significados, assumindo um caráter híbrido. Para estabelecer a diferença entre as medicinas e os procedimentos de pré-natal indígenas e não indígenas, os participantes qualificaram essas categorias empregando a noção de tradição por um lado - medicina tradicional indígena e pré-natal tradicional -, em contraposição às categorias qualificadas pelo termo 'branco' - 'medicina do branco' e 'pré-natal do branco'. Assim, a noção de tradicional passa a operar como um código diferenciador em oposição às formas institucionalizadas de assistência à gestação e ao parto. Mediante esse contraste, a ênfase dada aos traços distintivos da medicina tradicional e do pré-natal indígena possibilita que os sistemas de parto indígenas sejam articulados aos serviços de saúde. "Um deles é dado pelo contexto multiétnico mais amplo, que constitui o registro privilegiado no qual a diferença pode se manifestar. O outro é o cenário interno a cada sociedade" (Carneiro da Cunha, 2009: 372).

As categorias medicina tradicional e pré-natal indígena, em certa medida, configuram-se como imagens espelhadas da organização e dos procedimentos adotados pelos serviços oficiais de saúde na atenção à gestação e ao parto. Essas categorias são ambíguas por encerrarem entendimentos radicalmente diferentes para os agentes socialmente posicionados - tanto ocidentais quanto indígenas - que as acionam em seus discursos. Assim, essas categorias surgem como códigos de mediação que possibilitam a comunicação entre os povos indígenas e as políticas públicas, já que remetem ao esforço indígena para traduzir, nos termos dos não índios, certos aspectos do seu universo sociocultural.

Mas, parece que a analogia entre o pré-natal do branco e o pré-natal indígena não apenas fala do esforço para se fazer entendido, mas também constitui um projeto político, por encerrar a intencionalidade étnica de atribuir valor aos cuidados indígenas e conquistar o reconhecimento para as parteiras tradicionais, por exemplo.

As relações entre os povos indígenas e as políticas públicas, como as estabelecidas pelos cursos de aprimoramento de parteiras tradicionais ou pelos próprios encontros entre parteiras, pajés e AISs, propiciaram a emergência das ca- 
tegorias híbridas 'medicina tradicional' e 'pré-natal indígena'. Essas categorias, por sua vez, têm a virtude de conectar códigos generalizantes, tais como empregados pelas próprias políticas públicas - medicina tradicional indígena e pré-natal -, às categorias locais que remetem aos cuidados com a gestação e o parto - remédios do mato, dietas, folhas e rezas. Assim, as políticas públicas constituem projetos de produção simbólica e/ou cultural instaurando diferenças concretizadas por meio da tradução cultural que criam configurações híbridas (Hall apud Montero, 2006).

Assim, a reivindicação pelo reconhecimento oficial da parteira e pela sua consequente contratação remunerada, nos mesmos termos dos AISs, surge com a irrupção das políticas públicas no Alto Juruá. Esse fenômeno, que será abordado no próximo capítulo, forja novas configurações culturais ao redimensionar os nexos entre o local e o global, transformando os próprios sistemas indígenas de atenção ao parto vigentes na região. A emergência do cargo de parteiras tradicionais, propiciado pelos cursos, portanto, não só redefine os papéis dos cuidadores indígenas, mas também faz com que a própria concepção de saúde e doença seja redimensionada.

Notas

1 Apesar de os participantes não mencionarem essa prática nos encontros no Alto Juruá, segundo Lagrou (2007: 525), os Kaxinawa também fazem uso do kampô. Entre eles, "este emético é considerado um purificador e fortalecedor eficiente, e é usado em distintas ocasiões. Homens usam kampun para fortalecer seus corpos e para aumentar sua sorte na caça, e mulheres o aplicam quando querem engravidar".

2 Um dos significados de yuxin é a qualidade ou energia que anima a matéria. Nesse sentido, todos os seres vivos 'têm' yuxin, inclusive os animais. "É o yuxin que faz a matéria crescer, que the dá consistência e forma" (Lagrou, 2007: 347). 
Durante o encontro entre parteiras, pajés e agentes indígenas de saúde que ocorreu na TI Katukina de Campinas, a contratação remunerada das parteiras indígenas e o reconhecimento profissional desse ofício foram pontos debatidos pelos seus participantes. Os discursos proferidos revelaram as intenções étnicas e políticas de fazer dos cursos de capacitação de parteiras, e até mesmo desses eventos, uma forma de dar visibilidade à questão e criar condições para a conquista desse reconhecimento junto ao Estado. Tais intenções podem ser compreendidas como um dos projetos de developman dos povos indígenas do Alto Juruá.

De acordo com os indígenas que participaram desses eventos comunicativos, "as parteiras são profissionais formadas pela cultura". Entretanto, ao fazerem os cursos de parteiras, seus conhecimentos tradicionais e suas experiências na arte de partejar teriam sido tecnicamente aperfeiçoados, agregando valor profissional às suas práticas. Esse argumento esteve na base das reivindicações indígenas pelo reconhecimento e pela contratação remunerada das parteiras, tal como acontece com os agentes indígenas de saúde (AISs).

Porém, ao se propiciar o surgimento do cargo de parteira tradicional em sua acepção moderna, com os cursos, nas comunidades indígenas do Alto Juruá, criaram-se expectativas de que as mulheres que deles haviam participado seriam contratadas pelo Estado. Nesse contexto, a contratação consistiria numa maneira de as parteiras exercerem seu ofício com melhor qualidade, além de terem uma fonte de renda por meio da qual teriam acesso aos bens de consumo de que passaram a sentir necessidade.

Mas, ao reivindicar o contrato remunerado, que tipo de relação os povos indígenas do Alto Juruá estão querendo estabelecer com o branco? Que tipo de vínculo está sendo proposto? Qual a natureza dessa aliança?

No encontro de Campinas, o debate sobre a contratação das parteiras assumiu um tom reivindicatório, surgindo como um desdobramento da avaliação que os participantes fizeram dos cursos de aperfeiçoamento das parteiras indígenas. No entanto, as reivindicações por reconhecimento e a consequente contratação não se restringiram unicamente às parteiras. Os pajés katukina aproveitaram a 
oportunidade para também demandar a remuneração pelos serviços que prestam às suas comunidades.

Analisando os discursos proferidos nesse encontro, percebe-se que o contrato, particularmente para as parteiras, assume significados diferentes na fala de cada um dos seus participantes. Para as lideranças do movimento de mulheres indígenas dessa região, a conquista do contrato consolidaria o seu poder de representação perante as comunidades da região. Nesse caso, a luta pelo contrato se justifica em virtude do valor do trabalho que as parteiras realizam dentro de suas aldeias: "elas salvam vidas".

E hoje tá lá na $4^{a}$ Conferência da Saúde Indígena, com toda a certeza, as pessoas que foram daqui do Acre levaram também essa reivindicação: a valorização e o reconhecimento das parteiras indígenas. (...) Os profissionais de saúde não reconhecem! ó, a tia aí é um poço de sabedoria! Outras mulheres, outras parteiras são formadas na tradição, na sua cultura. Mas os técnicos brancos vão continuar dizendo que nós somos leigas, aquelas pessoas que não sabem, né? Então, nós queremos mostrar pra esses profissionais de saúde, pra esse pessoal formado que a gente nấo é nada de leiga: as parteiras, sim, são profissional! As parteiras têm a sabedoria! Os pajé tem a sabedoria própria, que o médico não tem! (Representante de mulheres indígenas)

Do ponto de vista das mulheres que ocupam a posição de parteiras, o contrato remunerado traria vários benefícios. Para as jaminawa-arara, a remuneração lhes possibilitaria doar alimentos e roupas para as mulheres pobres que estão assistindo. Até mesmo criaria condições para que elas removessem a parturiente para o hospital em partos complicados. Enfim, o contrato seria uma forma de melhorar as condições de trabalho da parteira e de lhes possibilitar ofertarem dádivas às mulheres que estão atendendo e às crianças que estão "pegando".

Se eu fosse contratada ajudaria bastante! Porque tem muitas mulheres que são mais pobrezinhas de que eu e, se eu fosse contratada, ajudava no alimento para o parto dela. Se fosse preciso levar pro hospital, eu mesmo pegava meu barco com motor e com meu filho e eu ia com ela. Isso tudo eu fazia. (Parteira jaminawa)

Até porque tem muita mulher que não tem as coisas também. Às vezes, vão ganhar neném e não tem uma manteiga, não tem um leite. Tudo isso, se a gente tivesse um contrato, podia comprar e também dá assistência pra elas. Porque, muitas vezes, a gente já dá sem ter o contrato. Muitas vezes, a gente tem mais do que elas, a gente pega um pacotinho de fralda, junta umas camisinhas. Tudo isso a gente dá. E com o contrato a gente pode fazer mais alguma coisa, nos dando condições pra gente trabalhar melhor ainda nas aldeias. Porque eu já gosto de ajudar as pessoas: o pouco que a gente tem, a gente tira da gente e leva pra elas. Já aconteceu de matar frango dos meus рга dar pra quem está de resguardo. 
E quando elas terminam o resguardo nem nos recompensam. (Outra parteira jaminawa-arara)

Uma representante das mulheres, por sua vez, alega que o contrato possibilitaria às parteiras tanto acompanhar as gestantes quanto resgatar as práticas tradicionais de resguardo pós-parto, porque assim elas teriam mais tempo para se dedicar ao seu ofício.

Eu acho que seria muito importante o contrato das parteiras pra (...) elas ter mais tempo de conversar com a grávida, acompanhar o parto realmente. Porque, às vezes, a parteira vai lá, pega o menino e vai embora, não fica com a mulher. Eu acredito que elas tendo esse contrato vão passar no mínimo três dias lá com a doente cuidando, como era antigamente. (Representante de mulheres indígenas)

Outro benefício do contrato, lembram as mulheres nawa e nukini, seria a potencial diminuição dos conflitos que as parteiras têm com seus maridos, os quais se incomodam quando a esposa deixa seus afazeres cotidianos para, sem receber nada, assistir uma mulher em um parto. Assim, o contrato seria uma forma de remunerar seus serviços prestados e também de compensar o tempo que deixa de trabalhar em casa ou na roça.

Como a parente falou: facilita mais por causa do tempo que a gente vai ter com as grávidas. Porque quando nós estamos na aldeia, nós não paramos não! É trabalhando direto! Além de trabalhar em casa, é trabalhando na roça. Muitas vezes, a gente larga o trabalho e vai atender paciente. Aí, o nosso esposo fica chateado: 'Tu deixa o teu trabalho pra fazer um parto e não ganha nada!' Eu digo: 'Mas Deus dá recompensa!'. (Parteira nukini)

A retórica da necessidade pelos bens dos brancos é forte nos discursos dos participantes dessa reunião. Nesse caso, o contrato remunerado seria uma forma de suprir as necessidades das famílias indígenas por certas mercadorias - roupas, sapatos, alimentos, material escolar etc. - justamente pelo fato de as comunidades estarem vivendo próximas ao mundo não indígena.

A necessidade também desse contrato das parteiras é porque hoje a gente tá no mundo dos brancos! A gente está vendo o movimento dos brancos. As próprias parteiras da comunidade perguntam: 'Porque os brancos contratam as brancas e nós, não?' Hoje você não vê uma 'parteira branca' no hospital [enfermeira] sem tá ganhando o seu salário. (...) Hoje, como o velhinho [pajé] ali disse, ninguém quer trabalhar mais de graça. Até porque a gente precisa, porque mais ninguém anda nu. Se a gente for andar nu na cidade vai até preso. Tem que comprar sandália, roupa, os filhos da gente vem aí. Então, a gente precisa disso! (Representante de mulheres indígenas) 
Aproveitando a discussão sobre a necessidade de contrato para melhorar as condições de trabalho das parteiras, os pajés katukina também passaram a reivindicar a contratação. Em suas falas, buscavam convencer aos demais participantes que eles também têm o direito de serem contratados, pois além de trabalhar com as parteiras, também curam outros tipos de doenças.

Eu vou colocar um pouquinho. Eu não vou explicar melhor, porque eu não sei falar português. Eu tenho trabalhado muito nessas coisas que você colocou. Eu estou com 45 anos de pajé. Já trabalho há muito tempo mesmo em conjunto com parteira. Se a parteira vê que não dá pra ganhar neném rápido naquele momento, ela me avisa que eu trabalho junto com ela. Eu conheço! É só chegar lá e eu conheço se mulher vai ganhar neném rápido ou se vai passar horas e horas. Eu conheço todo o trabalho porque eu sou pajé! Eu trabalho com espírito, eu conheço mesmo! E o trabalho que eu faço é o que eu sei. O trabalho que eu sei, só eu sei mesmo trabalhar pra toda a comunidade! Às vezes, precisa de mim lá de outra aldeia, aí me avisa e eu vou. (...) Não é só parteira não, todas as doenças eu sei curar. Deus o livre, se o pessoal adoece e morre, minha palavra mesmo já tinha escapado! Já salvei muita gente. Eu sei trabalhar mesmo é com espírito! Éo que eu queria colocar pra vocês e estou colocando. Muito obrigado! (Pajé katukina)

O argumento "hoje ninguém mais trabalha de graça" também é acessado pela fala dos pajés katukina. O fato de os agentes de saúde, conhecedores dos "remédios da farmácia", serem remunerados pelos seus serviços e os pajés que "rezam noite e dia" não o serem é motivo de preocupação. Para eles, isso desestimula os pajés, que passam a não querer mais trabalhar gratuitamente. Aquilo que as famílias teriam a oferecer pelo trabalho dos pajés no sistema de dádiva (Mauss, 1950; Goudbout, 1999), aparentemente, não os tem mais agradado. Existe agora uma demanda por bens e mercadorias que só se adquirem mediante pagamento em dinheiro.

Até hoje eu trabalho de graça. Hoje ninguém trabalha mais de graça. A gente fica muito preocupado se o pajé não trabalhar mais. Porque todo agente de saúde ganha dinheiro. Tá aí, agente de saúde que trabalha [com] 'remédio da farmácia' ganhando dinheiro, e nós perdemos nosso sono rezando noite e dia, trabalhando muito e de graça. 'Todo mundo está ganhando dinheiro e eu não vou trabalhar mais de graça!'. Vários deles falam assim: (...) 'Pra que que eu vou trabalhar? Para os outros ganhar?'. Nós tamos brincando, mas é verdade. Porque nós somos pobres. Porque quanto tempo que a gente perde pra rezar uma mulher grávida? Quanto tempo que a gente trabalha? Às vezes, a mulher sofrendo dois, três dias. Quando tempo a gente trabalha pra salvar o menino? Pajé vai dizer: 'Tô ganhando um dinheirinho, vou trabalhar!'. Assim a gente fica mais animado pra trabalhar! (Pajé katukina) 
Essas falas indicam que, na organização do cuidado à saúde, o pajé ocupa uma posição hierárquica superior às próprias parteiras. Com o discurso dos pajés, entende-se que eles teriam direito ao contrato tanto em razão do esforço empenhado para realizar curas nas gestantes e parturientes quanto pelo fato de sua atuação ser mais 'especializada' e abrangente do que a das próprias parteiras. Afinal, eles curam todos os tipos de doenças por trabalharem com espíritos. Vale lembrar que até pouco tempo atrás "qualquer um pegava menino" entre os Katukina e, geralmente, a assistência ao parto não era um assunto de especialistas. A intervenção especializada nos casos de complicações durante a gestação ou parto cabia, e ainda cabe, ao pajé. Logo, nos termos dessa lógica, se a parteira tem direito ao contrato por prestar serviços à comunidade, o pajé tem muito mais, na medida em que seu trabalho exige grandes esforços e encerra uma enorme responsabilidade.

A representante das mulheres da região reitera a importância do pajé, considerando-o como equivalente ao "médico branco". O dispositivo discursivo da mimese colonial (Bhabha, 2005) ou o chamado efeito espelhamento (Carneiro da Cunha, 2009) informa o argumento que sustenta a legitimidade da reivindicação das lideranças indígenas. "Porque hoje quem tem um pajé dentro duma aldeia pode dizer que tem um doutor! Não é nem todo doutor que sabe, que tem o conhecimento de um pajé!"

Uma parteira jaminawa-arara conta a forma como o pajé ashaninka, que atende a sua comunidade, cobra pelos serviços prestados. Entretanto, como pagamento ele não exige apenas dinheiro, mas também outros objetos.

Nosso pajé lá na nossa comunidade é de um povo e nós somos de outro. O nosso pajé lá é ashaninka! Há mais de vinte anos que ele mora com nós. Mas, pra ele fazer uma cura em qualquer parente tem que pagar. Às vezes, a gente diz: 'Txai, vamos curar Fulano!' Ele diz: 'Só se pagar!'. 'Pois, então, vamos, que nós paga!'. 'Paga com o quê?'. 'Quer roupa, quer rede... ', ele diz. 'Nós damo, Txai, 'mbora!' (...) Alguns dizem que ele [o pajé ashaninka] não sabe de nada. Aí, ele fica assim chateado. Mas só que ele já curou muita gente! Até de hepatite ele curou o meu irmão dentro da aldeia! Mas só que o pagamento é na hora! Aí, pronto! Depois que a gente paga, ele vai! Passa dois, três dias... Aí, quando tá bom ou bem melhor, ele vem embora pra casa. (...) Até agora, a tia tava muito doente, meu filho lutou pro pajé ir, e ele foi: 'Seu pajé sabe!'. 'Ah, Txai, pajé não vai não, só se trouxer ela pra cá!'. Levamos a tia, e ela melhorou em dois dias! O pajé curou! Nós saímos de lá e ela tava andando!

Parece que aqui temos um indício da forma como as relações estabelecidas entre os pajés e os seus pacientes durante o processo terapêutico fazem parte de um sistema de troca/dádiva (Mauss, 1950; Goudbout, 1999). Dessa maneira, a contratação e a remuneração dos pajés transformaria um sistema de dádiva em um sistema de Estado ou, no mínimo, faria surgir um sistema misto (Goudbout, 1999). 
Para o agente de saúde kaxinawa, tanto as parteiras quanto os pajés teriam o direito de serem contratados: para as parteiras, o contrato seria um estímulo a trabalharem como profissionais da assistência ao parto nas comunidades e uma recompensa pelos esforços empreendidos; para o pajé seria um reconhecimento de sua condição de "conhecedor da tradição". O AIS kaxinawa também demonstra preocupação com a possibilidade de os pajés pararem de trabalhar por não serem contratados, ocasionando grandes perdas para as comunidades.

Então, a questão é que hoje em dia todo mundo está querendo trabalhar e ganhar. o pajé lá teve essa conversa comigo. Eu como representante cheguei pra ele e pedi uma ajuda. Ele trabalha na saúde e trabalha no espiritual. Então, ele falou que tava trabalhando como pajé, mas que ia atender só a comunidade que ele morava, porque ali dentro ele tava sabendo o que estava fazendo. Agora em outra comunidade ele não curava porque podia ser, por exemplo, um feitiço feito por outra pessoa, né? Doença mesmo. Aí, se ele cura as pessoas, podem ficar com raiva dele. Sempre ele fala isso. (...) Ele me falou também que nós, agente de saúde, já estávamos sabendo mais do que ele sobre o mundo do nawa, porque entendemos do 'remédio da farmácia'. Mas da tradição, eu mesmo que tenho 21 anos, não sei. Ele tem todo esse conhecimento tradicional. Então, a questão fica assim: o agente de saúde trabalha como um agente branco, e ele trabalha com a coisa da tradição. (...) Então, se os pajés não trabalharem mais porque não têm contrato, se por acaso eles não ensinam mais, quem perde é a própria comunidade. É ela que vai sentir falta! (AIS kaxinawa)

Outro argumento acessado pelos participantes do encontro de Campinas que fundamentaria a reivindicação pelo contrato é o seguinte: já que os profissionais da saúde não índios são remunerados, as parteiras e os pajés que prestam serviços cotidianos às comunidades também teriam o direito de sê-lo. O fato de os profissionais brancos serem remunerados e as parteiras e os pajés não o serem surge como evidência da falta de reconhecimento pelo Estado do trabalho por eles realizado. A indignação com esse fato é expressa nesta fala de um AIS:

No caso de parteira aqui dos katukina, não tem nenhuma contratada, nem os pajés também. Porque cada aldeia aqui tem dois, três ou quatro pajés. Eles estão participando desse curso, porque nós chamamos. Eles nunca participaram de um curso. É a primeira vez que eles estão participando. Agora que eles estão conhecendo esse negócio da capacitação. Como eles colocaram: o médico está recebendo, a enfermeira está recebendo, o dentista está contratado. E nós, povos indígenas, não temos nenhum contrato: parteira não está contratada, pajé não está contratado. Nawa [branco] tá tudo ganhando, (...) tá tudo recebendo: enfermeira, auxiliar de enfermagem, dentista, médico. Tão tudo contratado em nome do índio! E o parente? E o nosso médico? Tá aí o pajé, tá aí a parteira sem ganhar nada! Eles estão precisando de roupa, eles estão precisando de sabão, eles precisam de 
um bocadinho de sal. Não tem nada pra eles viverem. Então, nós tamo passando muitas necessidades. Isso que eu queria colocar pra vocês!

A contratação da parteira e dos pajés, assim, seria uma forma de os indígenas trabalharem para eles mesmos, sem depender dos profissionais da saúde não índios para atenderem suas comunidades.

Então, é importante vocês estarem trazendo essa carreira de parteira. Isso é um novo trabalho também! Essas parteiras aqui no futuro podem ser contratadas. Não tem nada impossível! (...) Tudo isso é um trabalho pra, no futuro, nós trabalhar pra nós mesmo! (AIS kaxinawa)

A lógica que informa esses discursos se utiliza do dispositivo da comparação e do efeito de espelhamento entre o "mundo indígena" e o "mundo dos brancos" para traçar paralelos entre os cuidados prestados à saúde pelas parteiras e pajés no contexto comunitário e a atuação dos profissionais da saúde não índios. Foi sobre a comparação que os participantes indígenas da reunião se apoiaram para reivindicar o direito de serem remunerados pelos serviços que prestam ao seu povo, uma vez que os profissionais da saúde brancos já o são.

Mediante essa discussão, uma representante das mulheres indígenas chamou atenção para a necessidade de as próprias comunidades valorizarem o trabalho das parteiras e dos pajés, reforçando a importância de as famílias compartilharem aquilo que elas têm - caça, farinha, produtos da roça - com aqueles que lhes prestam assistência, não reduzindo a retribuição do favor prestado, simplesmente, ao pagamento em dinheiro. A representante ainda lembrou que a partir do momento em que os AISs e as parteiras começaram a participar de cursos de capacitação, os pajés se sentiram desvalorizados em sua comunidade. Isso criou um conflito interno nas aldeias. Uma forma de dirimir esses conflitos seria a criação de uma política que previsse a contratação tanto das parteiras quanto dos pajés.

Uma das antropólogas da equipe de execução dos encontros no Alto Juruá se engajou no debate acerca dos motivos que levam os brancos a não contratarem as parteiras e os pajés. Segundo ela, isso ocorre porque o "mundo dos brancos" não reconhece, nem valoriza o conhecimento tradicional. Por isso, é preciso que o povo lute para conquistar esse reconhecimento. Os encontros reforçariam essa luta, na medida em que contribuiriam para a construção de uma política de valorização e reconhecimento das parteiras. Nesse processo, coube às antropólogas assumirem a posição de porta-voz dos indígenas ao levarem as reivindicações dos participantes desses eventos para Brasília.

Então, é muito séria essa reunião! Ela não é só uma conversa, só uma troca de experiências. Ela vai ajudar a construir uma política de valorizar a parteira, de reconhecer a parteira. Então, é muito sério o trabalho que a gente faz! A gente 
não tá brincando! E eu acho que esse é o caminho pra brigar por uma melhoria pro trabalho de vocês: brigar de ter uma ajuda de custo para parteira, de ter um motor pra parteira, de ter um kit que seja reposto. (...) O que a gente está tentando fazer com essa reunião é levar essas coisas que vocês estão falando lá pra Brasília num relatório, e abrir espaço dentro da política de saúde pra eles valorizarem a parteira. Para eles reconhecerem que cada parteira aqui tem o seu conhecimento. (...) Mas só vai abrir espaço se a gente levar a voz de vocês. Por isso, a gente está preocupado em levar a voz de vocês para lá! (Antropóloga)

\section{O reconhecimento das parteiras pelos serviços de saúde e pelas comunidades}

Outro aspecto relacionado ao problema do reconhecimento que emergiu nos discursos durante o encontro da aldeia Morada Nova se refere à desconsideração das parteiras por parte dos serviços de saúde presentes na região. De acordo com os depoimentos prestados, a falta de reconhecimento das parteiras indígenas por parte dos profissionais da saúde se revela quando as proíbem de acompanhar as parturientes durante o trabalho de parto nos hospitais e maternidades. A chamada Lei do Acompanhante, Lei n. 11.108/2005 (Brasil, 2005b), garante o direito da mulher a ser acompanhada durante o trabalho de parto e o parto realizado no hospital. Porém, ao que tudo indica, esse direito não tem sido observado pelas unidades de saúde da rede do Sistema Único de Saúde (SUS) na região do Alto Juruá. Nessa região, de acordo com uma parteira kaxinawa, a permissão para acompanhar as gestantes é dada ou pela "parteira nawa" (enfermeira) ou pelo porteiro do hospital.

A parteira branca é que não deixa a gente entrar! Tem parteira boa, tem porteiro bom também pra gente entrar. Tem uns que deixam a gente entrar: tanto o porteiro quanto a parteira. Tem porteiro ruim, tem parteira ruim também, que não deixa entrar não! Aquele de bom coração, filho de Deus, manda a gente entrar. Aquele coração de Satanás não deixa entrar não!

A constatação da falta de reconhecimento das parteiras gerou um sentimento de indignação nos participantes dessa reunião, levando-os a reafirmar a necessidade de lutar pelo reconhecimento da parteira como profissional formada pela cultura no âmbito dos serviços de saúde.

Eu já levei duas pacientes pro hospital. A primeira vez, fui até a sala do parto, mas não consegui entrar, porque me mandaram sair. A segunda também, eu deixei a mulher na porta do hospital, porque o porteiro não me deixou entrar. A gente é reconhecida na aldeia como parteira, mas lá eles não nos consideram parteira. 
A gente tem que ser reconhecida aonde a gente vai. Se a gente vai levar a nossa paciente pro hospital, a gente tem que ficar com ela porque nós somos parteiras. Porque nós somos reconhecidas na comunidade e no hospital não? Assim não adianta! (Parteira kaxinawa)

Uma das propostas que surgiram, durante os eventos, a fim de solucionar o problema da falta de reconhecimento foi a criação de um crachá para identificar as parteiras, de modo a garantir que elas fossem respeitadas pelos profissionais do hospital. Mas a antropóloga da equipe de execução dos encontros defendeu que, mais do que um crachá, os hospitais deveriam ter uma lista com o nome das parteiras.

\footnotetext{
Não adianta só ter o crachá! O hospital tem que reconhecer (...) tendo, por exemplo, uma lista lá. Mas isso é uma luta, porque até hoje não tem nenhum hospital, nenhuma maternidade que deixa entrar. Isso é uma reivindicação das parteiras não só daqui: em Campinas e no Caucho falaram a mesma coisa. Isso é uma briga com a instituição mesmo! (Antropóloga)
}

Uma das consequências da falta de reconhecimento da parteira pelos serviços de saúde é o aumento da estranheza experimentada pelas parturientes ao terem a necessidade de dar à luz no hospital. Igualmente, essa falta de reconhecimento estaria associada à discriminação vivenciada pelos indígenas ao recorrerem aos serviços públicos de saúde. "Os hospitais são públicos: índio e não índio podem se socorrer lá. Só que a gente vai e é discriminado: 'Ah! Porque é índio!'. Aí, fica barrando as parteiras" (Parteira kaxinawa).

Outra dimensão do problema do reconhecimento das parteiras se refere aos contextos comunitários em que elas atuam. As falas de alguns participantes dos encontros sugerem que as parteiras, em algumas aldeias, não são reconhecidas pelas próprias gestantes.

Às vezes, as mulheres mesmo da nossa comunidade não procuram a parteira. Eu acho que elas não priorizam o que existe dentro da comunidade, pra priorizar os brancos, né? Eu acho que as mulheres da aldeia preferem ganhar na cidade porque tem médico e parteira boa. Não valoriza as parteiras da comunidade. (...) Porque nós aqui somos todas casadas, né? Por exemplo, as mulheres índias têm vergonha do médico e de outras mulheres. As índias nunca fizeram assim: deita, bota o pé aqui, bota acolá, fica tudo arreganhado pras outras vê. Se elas têm a vergonha de ganhar com as parteiras da aldeia, na cidade ainda é pior. É pior porque nós na comunidade, eu não sei as outras comunidades, mas eu tiro por mim: eu nunca ganhei daquele jeito! Meu jeito é antigo, como minha mãe fazia: tá na rede, eu seguro no pulso da rede e me acocoro e ganho meu filho. Então é isso que a gente faz. Eu achei muito diferente foi isso. As mulheres da aldeia saem dizendo que as parteiras da comunidade não entendem nada, não confia, pra vir fazer uma coisa que não deve fazer na cidade. Eu acho isso! (Mulher kaxinawa) 
Mas, se por um lado, algumas gestantes preferem recorrer ao parto hospitalar em vez de procurar à parteira, por outro, algumas continuam preferindo a assistência de suas mães no momento de dar à luz. "Eu sou parteira, mas é muito difícil o pessoal me procurar. Quando arrisca ganhar neném na aldeia, vai ganhar lá com a mãe. Aquelas que me procuram, eu ajudo; aquelas que não me procuram, eu não posso fazer nada, né?" (Parteira kaxinawa). Um AIS diz ser essa uma das maiores dificuldades enfrentadas pelas parteiras:

O que dificulta muito é isso: muitas das vezes, as grávidas não procuram as parteiras. Elas falam que não precisam de parteira, que elas mesmas sabem como se cuidar, né? (...) Outras vezes, as parteiras não tão na comunidade quando a grávida tá no mês de ter a criança. E, muita das vezes, ela procura a mãe. (...) A gente sabe que todas que ganham criança conhecem, sabem o que tem que fazer, mas eu acho que seria melhor se tivesse o acompanhamento da parteira ali no dia a dia pra deixar ela consciente do que precisa ser feito. (...) Mas outras pessoas que são tradicional mesmo, que nunca participaram de cursos, às vezes, também ajudam, fazem o parto. Então, isso é importante pra gente lá dentro. (AIS kaxinawa)

O fato de as gestantes não recorrerem aos préstimos da parteira capacitada indicaria, segundo esses discursos, que esta não é valorizada dentro de suas aldeias. E isso ocorreria por dois fatores: o primeiro é o receio, por parte da gestante, de que, caso aconteça alguma complicação durante o parto, a parteira não tenha os recursos necessários na aldeia para propiciar o nascimento de seu filho; o segundo é a própria atitude de algumas parteiras que comentam com outras pessoas da comunidade detalhes sobre a intimidade do evento de parto assistido por ela. Isso não estimularia as gestantes e parturientes a recorrerem aos seus serviços. Uma parteira kaxinawa explica por que as grávidas preferem o auxílio da mãe:

Na aldeia, a grávida não procura a parteira, até porque procura as suas mães ou outras pessoas que sejam mais importantes pra elas (...). Quando a parteira tá na comunidade, e vai procurar as mulheres que tão grávidas, as mulheres se recusam a dizer pra ela que tão grávidas. Isso é importante porque quem conhece a medicina da mata, no primeiro mês de gravidez tira aquele remédio, coloca dentro de um vaso e dá pra grávida tomar a água daquele remédio. Quando chega os nove meses, ela para de tomar. Por quê? Pra quando ela ter o parto a criança já nascer com tudo, já despachar com tudo! Não vai demorar nem 15 minutos pra ter o resto. Então desce com tudo. (...) Nós temos que ter a valorização da nossa comunidade. Temos que fazer elas ganhar ali, pra ela ter o parto normal com as crianças dela. Se tiver custando a ter o resto da criança, tem que fazer o remédio e ensinar a reza pra poder despachar rapidamente. Algumas coisas nós Kaxinawa temos a ciência. (...) O meu parto foi normal. Minha parteira só é eu mesma. (...) Se a pessoa não procura a parteira, procura a mãe, porque, como elas falaram, elas têm vergonha e as parteiras podem falar. (Parteira kaxinawa) 
Todavia, isso pode acontecer também pelo fato de a figura da parteira ser emergente em muitas comunidades indígenas do Alto Juruá, onde, tradicionalmente, o auxílio à parturiente no momento do parto era prestado por seus parentes mais próximos, como se viu anteriormente nas afirmações de Lagrou (2007).

\section{Contrato: sistema de dádiva versus sistema de Estado}

De acordo com o depoimento dos participantes dos encontros do Alto Juruá, os serviços prestados pelas parteiras e pelos pajés, tradicionalmente, eram, sim, retribuídos, mas com coisas produzidas na própria comunidade: produtos da roça, da caça ou da pesca; objetos artesanais ou mesmo mercadorias provenientes do mundo do branco, disponíveis para trocas em retribuição ao atendimento recebido.

Na reunião de Campinas, uma parteira jaminawa-arara conta que o pajé ashaninka que atende à sua comunidade cobra pelos seus serviços. Mas o pagamento pode ser feito com uma rede ou uma peça de roupa, e não necessariamente com dinheiro. Portanto, não se deve entender esse tipo de relação como um sistema privado de prestação de serviços de saúde, mas, sim, como um sistema de dádiva que envolve o processo de dar-receber-retribuir (Mauss, 1950).

Como dádiva, entende-se um sistema de relações sociais estabelecidas entre pessoas que pode se materializar em "qualquer prestação de bem ou serviço, sem garantia de retorno, com vistas a criar, alimentar ou recriar vínculos sociais" (Goudbout, 1999: 29). A circulação da dádiva instaura o vínculo, porque ela institui relações sociais. O estado de dívida faz parte da relação de dádiva, porque por meio dele o vínculo se mantém e se atualiza. Nos sistemas de dádivas, as coisas que circulam estão a serviço dos vínculos, e o valor das coisas é o próprio valor do vínculo que ela representa. Nos termos dessa lógica, portanto, os materiais do kit parteira são importantes justamente por expressarem o vínculo estabelecido com o mundo dos nawa, muito mais do que um valor utilitário.

Os serviços tradicionalmente prestados pelas parteiras e pelos pajés aos integrantes da sua comunidade representam um tipo de dádiva que, aparentemente, é gratuito (como aparece nos discursos de alguns participantes dos encontros que afirmam "trabalhar de graça"), mas obrigatoriamente requer uma retribuição, sob pena de aquele que prestou o serviço se sentir ofendido. Essa situação é expressa na fala das parteiras quando afirmam que, em muitas ocasiões em que são chamadas a assistir um parto, não recebem nem mesmo "muito obrigada" das pessoas que receberam seus préstimos.

A assistência ao parto que não, necessariamente, é prestada por uma parteira capacitada, mas sim por parentes próximos que auxiliam a mulher a parir, também está situada no registro da dádiva. A obrigação daquele que recebeu aju- 
da, nessa situação, é prestar auxílio aos parentes quando necessário. Quando esse auxílio é prestado pelo próprio esposo, então, o sistema de dádiva opera no âmbito dos grupos corporados, onde o idioma da substancialidade delineia os deveres e obrigações que configuram as relações entre cônjuges (Seeger, Da Matta G Viveiros de Castro, 1987; Gow, 1991).

Se é possível estender aos povos indígenas representados nas reuniões do Alto Juruá a afirmação de que os cuidados prestados às gestantes e às parturientes - sejam pelas parteiras e pajés, sejam pelos familiares e parentes próximos - estão situados no âmbito de um sistema de dádivas, é certo que esse sistema se configura de diferentes formas nos múltiplos contextos étnico-comunitários onde ocorre. Os sistemas de dádivas se configuram segundo a noção de tempo socialmente estabelecida para a sua retribuição. É a existência de um período entre o ato de dar e o de retribuir que atualiza o vínculo social, mantendo o receptor em dívida com o doador (Mauss, 1950).

Na sociedade moderna, o sistema de dádiva convive ao lado do sistema político de Estado e do sistema econômico - o mercado. O sistema de dádiva se diferencia dos outros sistemas por ser formado pelas relações estabelecidas entre pessoas, ao passo que o Estado e o mercado se caracterizariam pela ruptura com essas relações pessoais. O Estado, na condição de organização política moderna, constituise de relações administrativo-burocráticas marcadas pelos princípios da igualdade e da impessoalidade, ao passo que o mercado tem como valor preponderante o da liberdade, estando as relações sociais a serviço da produção e do consumo. Mesmo assim, a dádiva ainda pode se infiltrar nas relações estabelecidas nos âmbitos tanto do Estado quanto do mercado, criando sistemas mistos (Goudbout, 1999).

Essa discussão se faz importante, na medida em que a contratação remunerada dos serviços prestados pelas parteiras e pelos pajés faria com que um sistema de relações de troca, que originariamente ocorre no registro da dádiva, fosse deslocado para um sistema de Estado, tendo como justificativa principal a necessidade de se ter acesso a bens do mercado. Desse modo, as obrigações que as famílias assumiam ao receber os serviços desses cuidadores seriam transferidas para o Estado. A irrupção das políticas públicas nos contextos comunitários transformaria as relações de dádiva, pelas quais se orienta a organização dos cuidados à saúde, em sistemas mistos de relações.

Em uma primeira aproximação, os discursos dos participantes dos encontros ressaltam a dívida que o Estado tem com os povos indígenas dessa região, tanto por eles terem sido vítimas do processo histórico de conquista e de colonização quanto pelo fato de o trabalho desses 'cuidadores' comunitários não ser reconhecido pelo governo.

Esse não reconhecimento indicaria que um dos parceiros da relação não tem atendido a um dos imperativos do sistema de dádiva: o Estado não tem retribuído as parteiras e os pajés indígenas pelos serviços prestados à saúde de suas 
comunidades, mas remunera os profissionais da sąúde não indígenas. A viabilização do contrato remunerado, portanto, seria uma forma de o Estado reconhecer não só as parteiras e os pajés, como também a sua dívida com esses povos indígenas. Porém, ao se reivindicar ao Estado um contrato remunerado, não se está, necessariamente, demandando que as parteiras e os pajés sejam integrados ao sistema oficial de saúde, nem tampouco afirmando que eles irão se submeter à ordem hierárquica sobre a qual está pautada a organização dos serviços públicos de saúde do Estado.

Como evocado anteriormente, a remuneração e a contratação dos praticantes da medicina tradicional indígena pelo Estado, particularmente, das parteiras, estão condicionadas à regulamentação desse ofício. Isso implica instaurar um processo de profissionalização das parteiras por meio de cursos de qualificação profissional das parteiras tradicionais e de submetê-las à supervisão dos profissionais - médicos e enfermeiras - ao integrá-las aos serviços de saúde. O que é bastante diferente da reivindicação dos participantes dos encontros, que requerem o reconhecimento da parteira como uma "profissional formada pela cultura" e, portanto, uma 'profissional inata'.

O que as parteiras e os pajés estão solicitando é o contrato remunerado pelos serviços que já realizam em suas comunidades, sem que isso signifique a transformação das suas práticas e de seu modo de atuar. Acreditam, idealizando, que por meio do contrato suas condições de trabalho melhorariam, permitindo maior dedicação ao seu ofício, ao mesmo tempo que a remuneração garantiria a sobrevivência de sua família e possibilitaria o consumo das mercadorias dos brancos que lhes fazem falta. Assim, a lógica que informa essas reivindicações é a mesma utilizada na apropriação dos conhecimentos e das coisas do branco: esse contrato e a respectiva remuneração seriam incorporados ao mundo da vida indígena, de modo a atender aos seus próprios interesses de developman. Eles seriam indigenizados!

A solicitação de contrato por parte dos participantes indígenas requer que o Estado adote uma postura incondicional. Ou seja, as parteiras e os pajés querem ser remunerados e que o Estado tome essa providência, mas acreditam que continuarão a exercer os seus ofícios da mesma forma como vinham fazendo. Certamente, não contam com o fato de, uma vez contratados, passarem a ser supervisionados pelo poder administrativo do Estado por meio das práticas de vigilância dos funcionários públicos. Efeito que um contrato remunerado, inevitavelmente, traria; efeito, aparentemente, imprevisto para os participantes dos encontros do Alto Juruá; efeito instituído pela passagem de um sistema de dádiva para um sistema de Estado.

De qualquer forma, o contrato das parteiras e dos pajés seria mais uma via de acesso e apropriação dos recursos, bens e benefícios advindos da relação estabelecida com o mundo dos brancos. Entretanto, isso não quer dizer que o empreendimento colonial sobre esses povos seja neutralizado perante essas apropriações e seus respectivos processos de indigenizações. As coisas, conhecimentos e contratos advindos do mundo do branco, apesar de esvaziados semanticamente na 
fronteira, trazem consigo algo de sua sociedade de origem. É esse algo que escapa ao processo de apropriação indígena. Ou seja, contratar parteiras indígenas significa regulamentar e controlar o seu ofício. Talvez se possa pensar esse algo excedente que permanece no objeto apropriado como equivalente ao hau da coisa dada - o espírito da coisa (Mauss, 1950). Nesse caso, o que permanece informando os objetos apropriados é a própria alma do estrangeiro que injeta uma dimensão "venenosa", porque colonizadora, no próprio artefato que circula - seja ele um conhecimento, uma coisa ou uma relação. Porque, no caso dos objetos provenientes do mundo do branco, o Estado continua a exercer a força do direito sobre o que ele doou. Nesse sentido, aceitar um dom é aceitar que outro exerça algum poder sobre quem o recebe (Godelier, 2001).

\section{Contrato, reconhecimento e a mímica colonial}

Os participantes dos encontros entre parteiras, pajés e AISs almejam o reconhecimento das parteiras e dos pajés indígenas como equivalentes em valor e conhecimento aos profissionais - médicos e enfermeiros - que ocupam as posições hierárquicas mais altas dos serviços públicos de saúde. Inúmeras vezes, referiu-se aos pajés equiparando-os em experiência aos "médicos do branco". Da mesma forma, as parteiras indígenas foram comparadas às "parteiras brancas" (enfermeiras que trabalham nas maternidades e hospitais). Essa equivalência entre os conhecimentos e as funções se constitui como um recurso discursivo político utilizado para, ao evidenciar o valor do trabalho das parteiras e dos pajés nos termos do outro-branco, legitimar as reivindicações por contrato remunerado.

Ao estabelecer essa equivalência, os participantes das reuniões estão operando com o dispositivo de poder da mimese colonial, que tem a virtude de instaurar um processo de imitação e repetição por parte dos povos indígenas da forma de ser e de fazer do colonizador. Desse modo, eles respondem ao desejo do colonizador de ver o outro-indígena, "reformado, reconhecível, como sujeito de uma diferença que é quase a mesma, mas não exatamente" (Bhabha, 2005: 127). Os saberes oficiais contribuem para a produção do sentido e das relações de poder que articulam as diferenças em uma ordem hierárquica colonizadora.

A mímica é, assim, o signo de uma articulação dupla, uma estratégia complexa de reforma, regulação e disciplina que se apropria do Outro ao visualizar o poder. A mímica é também o signo do inapropriado, porém uma diferença ou recalcitrância que ordena a função estratégica dominante do poder colonial, intensificando a vigilância. (Bhabha, 2005: 127) 
O reconhecimento da equivalência entre a atuação das parteiras e pajés e das enfermeiras e médicos não indígenas, reivindicado pelos participantes dos eventos, também pode ser pensado como um efeito de espelhamento que emerge no contexto de negociações políticas estabelecidas entre os povos indígenas e o Estado. Isso porque, por meio dos argumentos que informam tal reivindicação, busca-se espelhar explicitamente a estrutura da biomedicina, ou o que dela se apreende, ao mesmo tempo que se exige o seu reconhecimento (Carneiro da Cunha, 2009: 343).

De qualquer forma, acredito ser o dispositivo da mimese colonial, o qual informa os discursos oficiais sobre os cursos de qualificação/capacitação dos praticantes das medicinas tradicionais indígenas - entre eles as parteiras -, que institui tais cursos como condição para integrar os praticantes da MT aos sistemas nacionais de saúde. Assim, por meio desses cursos, o indígena seria reformado, tornando-se reconhecível ao olhar do sistema oficial de saúde. Eles seriam transformados em 'quase' profissionais da saúde, mas não exatamente.

Portanto, ao reivindicar ao Estado o reconhecimento de parteiras tradicionais e pajés como equivalentes às enfermeiras e aos médicos brancos, os participantes desses eventos comunicativos também operam com o discurso oficial colonizador, no intuito de realizar seus próprios projetos. Nesse caso, o contrato aparece como vínculo social materializado, pois oficialmente instituído entre povos indígenas e Estado, comprometendo este a atender aos interesses e às necessidades indígenas de desenvolvimento sociocultural e também econômico.

\section{O problema do reconhecimento}

O reconhecimento oficial do trabalho das parteiras e dos pajés, como aparece nos discursos dos participantes dos encontros no Alto Juruá, implica um contrato remunerado: reconhecer significa contratar e remunerar pelos serviços prestados à comunidade. Assim como o kit parteira é a materialização dos conhecimentos adquiridos durante os cursos de aperfeiçoamento das parteiras tradicionais indígenas, o contrato remunerado seria a materialização do seu reconhecimento pelos brancos. Dessa forma, a questão do reconhecimento aqui se volta para a relação que esses povos estabelecem com o mundo externo, com o outro-nawa, diferentemente do reconhecimento das parteiras no âmbito comunitário.

A luta pelo reconhecimento está voltada para a relação com o outro, na medida em que se almeja conquistar o seu reconhecimento. Só pode dar reconhecimento àqueles que não só detêm o poder para tanto, mas que de antemão são reconhecidos pelos agentes que o reivindicam (Caillé, 2008). Ao se tomar ciência desse princípio da luta do reconhecimento, percebe-se que tanto as comunidades indígenas quanto os brancos de quem almejam o reconhecimento já são reconhe- 
cidos pelos indígenas como detentores do poder simbólico de, ao reconhecer, fazerem existir pela nomeação: a comunidade, nomeando uma mulher para ocupar o recente cargo de parteira; e o Estado, contratando e remunerando os seus serviços ao reconhecer esse cargo.

Se os povos indígenas reivindicam o reconhecimento do branco é porque, de alguma forma, este detém objetos e poderes desejados. Reconhecer o valor dos conhecimentos e das coisas do branco é querer se apropriar deles como uma forma, também, de conquistar o seu reconhecimento. Isso acontece, por exemplo, no caso das parteiras que fizeram os cursos e agora têm certo domínio de conhecimentos e materiais ali adquiridos. Assim, o contrato se configura como sinal materializado do reconhecimento e da valorização pelos 'brancos' do trabalho realizado pelas parteiras, trabalho esse tecnicamente aperfeiçoado pelos cursos que elas fizeram.

A luta pelo reconhecimento das parteiras e dos pajés indígenas acontece em um contexto de multiculturalismo (Ricoeur, 2006; Taylor, 1994), na medida em que se refere também às discriminações historicamente vivenciadas pelos povos indígenas no processo de constituição dos Estados nacionais. Nas lutas por reconhecimento conduzidas por grupos minoritários e subalternos, eles enfrentam autoimagens "depreciativas, desdenhosas e aviltantes" (Ricoeur, 2006: 228) que lhes foram inculcadas pelo processo colonial. "A gravidade da falta de reconhecimento de que os membros desses grupos se sentem vítimas provêm da interiorização dessa imagem sob a forma de autodepreciação" (Ricoeur, 2006: 228).

O tom de indignação que marcou a fala dos participantes das reuniões no Alto Juruá demonstra o quanto a falta de reconhecimento das parteiras pelos serviços de saúde - principalmente quando a elas se nega o direito, legalmente garantido, de acompanhar as mulheres durante os trabalhos de parto que ocorrem no hospital - é entendido como agressão e falta de respeito por elas e pela própria comunidade. Na medida em que a negação do reconhecimento coloca em xeque o respeito que a pessoa tem por si mesma, alguns sentimentos, como a indignação, assumem o caráter de resposta moral, passando a impulsionar a luta pelo reconhecimento. "O ponto mais sensível da indignação diz respeito ao contraste insuportável (...) entre a atribuição igual de direitos e a distribuição desigual de bens em sociedades como a nossa" (Ricoeur, 2006: 214-215).

O problema do reconhecimento, como evidenciado pelos discursos proferidos durante os eventos comunicativos aqui considerados, encerra dois níveis distintos: o primeiro faz referência ao reconhecimento das parteiras e dos pajés no contexto interno das comunidades indígenas; o segundo se refere à relação que os povos indígenas estabelecem com o Estado-nação e, portanto, se refere à dimensão normativa do reconhecimento. 


\section{A dimensão interna do reconhecimento: as comunidades}

No interior das comunidades indígenas, onde são estabelecidas as relações entre as parteiras e os pajés e as famílias de quem eles cuidam, o problema do reconhecimento se desdobra em duas vertentes: por um lado, as pessoas para quem eles prestam os seus serviços, em muitas situações, nem mesmo os agradecem pelo auxílio recebido, por outro, no caso das comunidades em que o advento da parteira é recente, as mulheres que assumiram esse cargo reclamam pelo fato de as gestantes não as procurarem para lhes pedir ajuda, preferindo recorrer ou às "parteiras brancas" dos hospitais ou mesmo às suas mães.

No primeiro caso, a falta de reconhecimento está intimamente associada ao processo de desvalorização dos saberes, das práticas, dos praticantes e das instituições tradicionais de cuidado com a saúde que as comunidades indígenas vêm enfrentando atualmente. $E$ atesta também o fato de as relações de dádiva não estarem sendo atualizadas, em algumas situações, dentro das aldeias. Ao assistir o parto de uma mulher e não receber nem mesmo um agradecimento pelo serviço prestado, o dom ofertado não chega a ser reconhecido. A falta de reconhecimento impossibilita o ato de retribuição, na medida em que não instaura um sentimento de endividamento dessa família com a parteira. É o sentimento de gratidão que inscreve o reconhecimento no domínio da dádiva. E, assim, a própria estrutura social que organiza as operações de reciprocidade, em que se poderiam localizar os sistemas de parto tradicionais indígenas, está em xeque.

Reconhecer é admitir que houve um dom, que somos devedores daquele que o fez e que permaneceremos interagindo com ele, convocados a dar quando chegada a nossa vez. Reconhecer é, de certo modo, portanto, assinalar um reconhecimento de dívida, ou ao menos de dádiva. (...) Reconhecer uma pessoa é admitir seu valor social e lhe oferecer qualquer coisa em retorno. Em que consiste este valor? (...) O que é reconhecido socialmente é a existência de um dom. Este valor (...) é a capacidade da pessoa de dar, a relação que ela mantém com o universo da dádiva. (Caillé, 2008: 158)

Na fala dos indígenas, o reconhecimento e a valorização das parteiras e dos pajés pelas próprias comunidades aparecem como fundamentais para garantir que tais cuidadores continuem atuando no interior das aldeias. Essa importância para a comunidade seria expressa, assim, pela atitude das famílias beneficiadas de partilhar aquilo que têm com os pajés e as parteiras de modo a retribuí-los pelos serviços prestados. Aqui haveria, se não um retorno, um reforço do sistema de dádiva que estruturava tradicionalmente a organização comunitária dos cuidados com a saúde.

Durante o encontro de Campinas, os pajés katukina foram categóricos ao afirmarem que não querem mais trabalhar de graça, que significa operar no registro 
do dom, onde não se recebe pelos serviços ofertados, mas se é retribuído. Entretanto, aquilo que pode ser retribuído pelos serviços do pajé, mesmo quando aqueles que receberam o auxílio nutrem um sentimento de gratidão pelos seus préstimos, não tem sido suficiente para atender às novas necessidades das famílias indígenas e dos próprios pajés. Assim, surge a demanda por dinheiro como meio de acessar os bens e mercadorias tão desejados, provenientes do mundo do branco. O contrato remunerado seria uma forma de se obter dinheiro!

Já o segundo caso está associado à conquista de reconhecimento de um novo agente de cuidado com a saúde que ocupa um cargo emergente em algumas comunidades indígenas do Alto Juruá: as parteiras. Ter participado dos cursos de parteiras e possuir os materiais do kit constituem símbolos de distinção que fazem referência ao reconhecimento que o outro-estrangeiro, os nawa, concede às mulheres. Esses sinais são manipulados internamente por elas no intuito de demarcar a sua autoridade para assistir os partos nas aldeias e conquistar o reconhecimento e o respeito da sua comunidade.

As parteiras emergentes surgem no contexto comunitário fazendo frente às formas tradicionais de cuidados com a gestação e o parto, baseadas no conhecimento 'encorporado' sobre a prática de gestar e parir. Nos termos dessa lógica, a conquista do reconhecimento das parteiras requer que as mulheres deixem de acreditar em sua capacidade de gerar e parir, e de decidir quanto ao tipo de auxílio de que elas necessitam. Também relega aquelas mulheres com experiência prática em "pegar menino", mas que não participaram dos cursos, a um lugar de não reconhecimento, equivalente à condição de não existência.

Almeja-se que a comunidade reconheça e respeite os pajés e as parteiras por prestarem serviços importantes e por serem detentores de conhecimentos específicos tanto acerca da prevenção e cura das doenças quanto do ofício do partejar. O reconhecimento, assim, é solicitado tanto para os agentes - parteiras e pajés quanto para os conhecimentos que eles detêm. Porém, se reconhecer os agentes sociais é atribuir-lhes um valor relativo à sua capacidade de doar, o objeto a ser reconhecido é a própria habilidade das parteiras e dos pajés de cuidar da saúde da sua comunidade e de dar respostas eficazes às situações que requerem a sua atuação - realizar um parto, no primeiro caso; fazer uma cura, no segundo. Espera-se, portanto, que esse reconhecimento provenha tanto da comunidade em que esses cuidadores atuam quanto do próprio Estado.

\section{O reconhecimento nas relações com o mundo externo: o Estado}

A esfera do dom localiza-se na relação que esses cuidadores estabelecem com aqueles parentes que eles auxiliam no âmbito comunitário. Já na relação que os povos indígenas estabelecem com o Estado, o reconhecimento sai do domínio do 
dom e adquire uma dimensão normativa. O que os participantes dos encontros do Alto Juruá solicitam do Estado é um reconhecimento normativo baseado nas capacidades dos cuidadores indígenas da saúde: as parteiras e os pajés. "As lutas pelo reconhecimento jurídico provêm dessa inteligência mista das coações normativas e das situações em que as pessoas exercem suas competências" (Ricoeur, 2006: 213).

Adentra-se no segundo nível da luta pelo reconhecimento, aquele que se volta para a relação que os povos indígenas mantêm com o mundo externo, com os brancos e suas instituições, particularmente com o Estado-nação. Todavia, nessa dimensão, para ser reconhecido, é necessário se fazer existir, tornando-se visível aos brancos. "Lutar para ser reconhecido não significa nada além do que lutar para se ver reconhecer, atribuir ou imputar um valor" (Caillé, 2008: 158). De fato, para que o Estado possa reconhecer algo ou alguém, é preciso que esse algo/alguém exista e, para existir, é necessário que o Estado o nomeie. Assim, o poder de reconhecer do Estado está associado ao poder simbólico da nomeação.

Caillé afirma que o conhecimento e reconhecimento são indissociáveis e que ambos se encontram no entrecruzamento das "formas de classificação que permitem pensar e conhecer o mundo" (2008: 154). O reconhecimento que conhece acaba por ser aquele que normatiza. Talvez seja esse o único reconhecimento que pode ser oferecido pelo Estado: o normatizador, o regulador. Desse modo, para reconhecer, o Estado precisa transformar os objetos que reivindicam reconhecimento em algo reconhecível. Esse é um dos papéis desempenhados pelos cursos de qualificação dos praticantes das medicinas tradicionais, particularmente, o das parteiras tradicionais.

A luta pelo reconhecimento, de certa forma, remete à aspiração por igualdade de condições de trabalho e, consequentemente, de igual respeito a todos os cuidadores da saúde indígena. O fato de os AISs receberem por seu trabalho e as parteiras e os pajés não receberem demonstra que o respeito por parte do Estado não é distribuído de igual forma entre esses cuidadores indígenas da saúde. Assim, a reivindicação pelo contrato se constituiria numa forma de normatizar o reconhecimento, mediante o acesso a condições comuns de exercício de suas atribuições entre esses diferentes cuidadores e também dos profissionais da saúde não indígenas.

O reconhecimento não indígena, como almejado pelos participantes indígenas dos encontros, apresenta em seu bojo a reivindicação por respeito tanto por esses cuidadores da saúde quanto pelos saberes e práticas por eles dominados. Eles esperam que os profissionais da saúde, assim como os gestores, reconheçam o seu valor e respeitem o seu trabalho. Na medida em que o respeito constitui uma modalidade de reconhecimento que, em geral, precisa ser garantida por meio do sistema jurídico e também político (Caillé, 2008), o reconhecimento do ofício das parteiras e dos pajés não teria como fugir do dispositivo regulador das políticas públicas - forma por meio da qual o Estado faz valer os direitos socioculturais dos povos indígenas. 
Uma das questões suscitadas pelo reconhecimento das parteiras e dos pajés quando se remete à relação com os não índios é a de saber se o valor desses agentes do cuidado é intrínseco ou é adquirido apenas na medida em que se espelham no fazer dos profissionais da saúde. Se adquirido for, o trabalho das parteiras e dos pajés tem valor, na medida em que parece com o dos médicos e enfermeiras. Mesmo quando se afirma que tais cuidadores são "profissionais formados pela cultura", os traços acessados pelo discurso para indicar o valor de sua atuação são aqueles que encerram certas semelhanças, mesmo que seja um efeito discursivo, com as práticas exercidas pelos profissionais da saúde.

Essas estratégias discursivas utilizadas na luta pelo reconhecimento estão pautadas em uma conduta comparativa que, ao criar o efeito espelhamento, busca estabelecer o valor do 'eu' nos termos valorizados pelo outro. Desse modo, procura assumir formas já conhecidas e valorizadas pelos brancos e, portanto, passíveis de serem reconhecidas por eles. A reivindicação direcionada aos brancos, nesse caso, implica o reconhecimento da contribuição das parteiras e pajés como igualmente válidas e valiosas aos serviços prestados pelos profissionais da saúde não indígenas. Mas para reconhecer o Outro, é preciso ver nele algo de si mesmo. Por isso, os discursos oficiais utilizam critérios previamente estabelecidos para poder outorgar reconhecimento àqueles que o reivindicam.

Os critérios que possuímos, porém, são os da civilização do Norte do Atlântico. Consequentemente, os juízos irão, implícita e inconscientemente, enfiar os outros nas nossas categorias até estas abarrotarem. (...) Ao invocar os nossos critérios para julgar todas as civilizações e culturas, a política da diferença acabará por tornar todas as pessoas iguais. (Taylor, 1994: 91)

No entanto, os indígenas querem ser reconhecidos como iguais aos nawa em sua diferença. Reconhecer que as culturas indígenas têm igual valor à dos não índios, principalmente no campo da saúde, é o que está colocado na base da reivindicação por reconhecimento. Assim, uma política de reconhecimento, como resposta às reivindicações dos povos indígenas, deve ser construída mediante um processo dialógico pautado no reconhecimento mútuo do valor dos agentes envolvidos no processo de interlocução e negociação junto ao Estado-nação (Ricoeur, 2006: 230).

\section{O ponto de vista da gerência da Área de Medicina Tradicional Indígena}

Ao delinear um projeto de pesquisa-ação a partir da negociação estabelecida com a liderança de mulheres indígenas, que tinha como base a proposta de realização dos cursos de aperfeiçoamento das parteiras tradicionais indígenas, 
eu intencionava instaurar um processo de valorização dos saberes, práticas e cuidadores indígenas da gestação e do parto em função de sua importância intrínseca para a reprodução biopsicossocial dos povos abarcados pelos encontros entre parteiras, pajés e AISs que ocorreriam nas regiões do Alto Juruá e do Alto Purus. Por isso, procurava não reforçar os mecanismos de individualização, instrumentalização, subordinação e descontextualização das parteiras indígenas de seus contextos comunitários que, inevitavelmente, adviriam com o processo de profissionalização dessas praticantes das medicinas tradicionais indígenas.

Como antropóloga que atuava na gerência da Área de Medicina Tradicional Indígena (AMTI), eu acreditava que as políticas públicas deveriam atentar para os contextos e as redes comunitárias indígenas de cuidados com a saúde. Para tanto, tais políticas deveriam contribuir com os povos indígenas nos seus esforços para sustentar de forma autônoma os saberes, práticas, praticantes e instituições socioculturais considerados por eles importantes. Ou seja, as políticas públicas deveriam cooperar para criar condições de sustentabilidade das medicinas tradicionais indígenas, evitando instituir relações de dependência desses povos em relação ao Estado. Da mesma forma, tais ações não poderiam desconsiderar as novas necessidades de subsistência e consumo vivenciadas por essas comunidades atualmente.

Na verdade, a proposta dos cursos de aperfeiçoamento de parteiras tradicionais indígenas, inicialmente apresentada à AMTI, estava informada pelos interesses indígenas vinculados à luta pelo reconhecimento profissional das parteiras e a sua consequente contratação remunerada pelo Estado. Porém, no decorrer da negociação com a liderança de mulheres indígenas, essa proposta foi redimensionada: passou a congregar não só parteiras, mas também outros cuidadores indígenas da gestação e do parto, em eventos comunicativos propícios à reflexão, por meio do diálogo e da troca de experiências, sobre a atual situação dos sistemas indígenas de atenção ao parto nas regiões do Alto Juruá e do Alto Purus. Com isso, eu pretendia dar visibilidade à organização sociocultural dos cuidados prestados às gestantes, parturientes, puérperas e recém-nascidos nos contextos comunitários indígenas, desvelar as relações de parentesco, de gênero e de substancialidade que as informam, e focar na dimensão coletiva da assistência prestada, e não em um único cuidador.

Desde o início, deixei claro para a liderança indígena que a AMTI não financiaria projetos de capacitação dos praticantes das medicinas tradicionais indígenas por entender serem eles próprios os especialistas nos conhecimentos e práticas utilizados para fazer saúde e curar doenças nos contextos comunitários. Por isso, explicitei também que a AMTI não apoiaria iniciativas voltadas para profissionalização das parteiras, consideradas aqui como um desses praticantes.

Pelo contrário, a intenção era promover ações que fortalecessem e valorizassem os saberes, as práticas e os praticantes da medicina tradicional indígena pelo seu valor intrínseco, na medida em que são importantes para a produção e 
reprodução biossocial e cultural dos povos indígenas. A preocupação era, com base nos resultados da pesquisa, por um lado, desenvolver estratégias de articulação entre o sistema oficial de saúde e os sistemas indígenas de atenção ao parto, de modo a qualificar a atenção à saúde materno-infantil indígena e, por outro, identificar alternativas para promover a sustentabilidade e a autonomia das medicinas tradicionais indígenas em seus contextos comunitários, ao invés de estreitar ainda mais os laços de dependência estabelecidos entre povos indígenas e o Estado. Ou seja, criar condições para que as próprias comunidades e povos indígenas sustentassem os saberes, as práticas, os praticantes e as instituições considerados importantes para a manutenção do seu bem-estar e da sua saúde.

Para tanto, a metodologia de pesquisa-ação participativa se mostrava estratégica. Por um lado, a curto prazo, proporcionaria a mobilização indígena para refletir e construir estratégias próprias de manutenção e atualização das suas medicinas tradicionais, instituindo o princípio de corresponsabilidade no desenvolvimento das ações. Por outro, a médio e longo prazos, os conhecimentos produzidos pelas ações da pesquisa fundamentariam o processo de planejamento dos programas e políticas públicas de saúde da mulher indígena, fazendo com que as atividades desenvolvidas fossem culturalmente adequadas de modo a contemplar, efetivamente, as necessidades das populações indígenas.

Talvez essa perspectiva dentro do Estado seja contra-hegemônica, na medida em que a tendência, como se viu quando foram discutidos os discursos oficiais, era justamente integrar as medicinas tradicionais indígenas aos sistemas de saúde nacionais, por meio do processo de validação científica de seus saberes e de suas práticas e da qualificação dos seus praticantes. O objetivo da AMTI, por sua vez, era criar estratégias para a articulação planejada entre as práticas e praticantes das medicinas tradicionais e os serviços de saúde, uma articulação diferente daquela que vigora nos processos de apropriação e indigenização dos conhecimentos e das coisas do branco realizados pelos indígenas.

Ao deixar claro que a profissionalização e a contratação das parteiras não eram um objetivo da AMTI, nem tampouco do projeto de pesquisa-ação financiado, eu procurava evitar que os participantes dos encontros entre parteiras, pajés e AISs criassem expectativas de que o projeto ou mesmo a área atenderia às suas reivindicações por contrato remunerado, até porque não tinha poder para tanto.

Subjacente à tomada de decisão de não financiar os cursos de aperfeiçoamento das parteiras tradicionais indígenas, no exercício de uma gestão antropologicamente orientada da AMTI havia a preocupação com os efeitos que os cursos poderiam ter sobre as formas comunitárias de organização dos cuidados prestados à gestação e ao parto. Como é de conhecimento da comunidade antropológica, os saberes e as práticas indígenas utilizados durante esse período não só preservam a saúde e tratam das doenças, como também estão a serviço do processo de produção de corpos e de pessoas aparentadas e engendradas, sendo fundamentais para 
a construção das identidades indígenas. Nesse caso, é sobre esse processo que os cursos de parteiras intervêm diretamente.

Os conhecimentos anatômicos, veiculados pelos cursos de capacitação de parteiras, são, em termos epistemológicos, radicalmente diferentes dos saberes relativos à concepção e à reprodução vigentes entre os povos indígenas. Saberes os quais estão associados ao idioma da substancialidade que informa as relações de parentesco. Os conhecimentos veiculados pelos cursos não são meramente técnicos, mas estão carregados de valores provenientes da sociedade ocidental, mais especificamente do modelo médico hegemônico. Apesar da boa vontade daqueles que promovem e realizam os cursos, os conhecimentos transmitidos ali têm status de verdade, não sendo apresentados no contexto dos cursos como mais um tipo de conhecimento possível, dentre tantos outros - como aqueles de domínio das mulheres indígenas.

Portanto, podemos nos perguntar: como os conhecimentos difundidos durante esses cursos são apreendidos pelas mulheres que dele participam, e quais os efeitos que eles produzem na prática cotidiana de atenção à gestação e ao parto? Pode-se ter uma noção desse impacto com base na fala dos participantes dos encontros do Alto Juruá, mas, na verdade, não se tem exatamente a resposta! Seria necessário um estudo mais aprofundado para se avaliar o impacto desses cursos sobre a organização sociocultural do cuidado no contexto das comunidades indígenas.

Logo que assumi a posição de gerente da AMTI, os gestores do Departamento da Saúde Indígena, em parceria com a Área Técnica de Saúde da Mulher, do Ministério da Saúde, tinham a intenção de, cada vez mais, promover cursos de capacitação para as parteiras indígenas e fazer um cadastro nacional dessas parteiras. O discurso que justificava a relevância desses cursos era que eles contribuiriam para reduzir as taxas de mortalidade materno-infantil (neonatal) indígenas associadas ao parto. Ao que tudo indica, essa intenção política foi retomada pelos gestores da recentemente criada Secretaria Especial de Saúde Indígena do Ministério da Saúde (Sesai/MS).

Todavia, o subsistema de Atenção à Saúde Indígena não produziu informações sistemáticas sobre as condições em que são realizados os partos assistidos por parteiras, nem tampouco sobre as morbidades e mortalidades a eles associados. Além disso, até mesmo as informações sobre partos indígenas hospitalares são precárias, porque a parturiente, ao adentrar na rede de atenção do SUS, raramente é identificada como indígena, e muito menos ainda pela etnia à qual pertence. Portanto, não se sabe exatamente quais são as morbidades, nem os índices de mortalidade associados ao parto domiciliar realizado por parteiras. Tampouco há informações sobre as morbimortalidades associadas aos partos hospitalares e sobre a qualidade da assistência prestada às parturientes indígenas em hospitais e maternidades do SUS. Como planejar ações culturalmente adequadas para reduzir as taxas de mortalidade materno-infantil nesse caso? 
O discurso que defende os cursos de capacitação de parteiras como um meio de reduzir as taxas de morbidades e mortalidades materno-infantil parece estar pautado muito mais em princípios ideológicos, tais como aqueles veiculados pelo imaginário higienista (Tornquist, 2004), do que sustentado sobre evidências concretas, produzidas com base no conhecimento profundo e sistemático da situação de saúde das gestantes e das parturientes indígenas e das condições de assistência aos partos - tanto domiciliares quanto hospitalares. Essas informações, o sistema oficial de saúde tem por obrigação produzir.

Muito provavelmente, esses discursos sejam um resquício da mesma ideologia higienista que, ao longo do século $\mathrm{XX}$, associou o ofício das parteiras à sujeira e ao perigo. Os cursos de parteiras realizados desde o século XIX tinham como função difundir os conhecimentos médicos a respeito dos procedimentos de higiene e anatomia. Já naquela época, as mulheres que faziam os cursos procuravam se profissionalizar e agregar prestígio e valor à sua prática, distinguindose das demais parteiras que, por não saberem ler, não participavam dos cursos, tornando-se excluídas do processo de profissionalização das parteiras e relegadas a um lugar marginal, subalterno e estigmatizado, em razão do qual passaram a ser, pejorativamente, denominadas "comadres, entendidas e curiosas" (Tornquist, 2004). Esses cursos contribuíram para transformar a assistência aos partos: dos cuidados da parteira para a profissionalização da atenção. Assim, constituíram-se em dispositivos de medicalização do parto e do próprio ofício das parteiras e da arte de partejar.

O que faz crer que isso não venha a ocorrer novamente, agora entre os povos indígenas, com a realização desses cursos de capacitação de parteiras? Em que medida esses cursos não contribuiriam para medicalizar tanto a gestação e o parto indígenas quanto as formas comunitárias de assistência às gestantes, às parturientes, às puérperas e aos recém-nascidos?

$\mathrm{O}$ que se percebe nos discursos dos participantes dos encontros do Alto Juruá é que os cursos de parteiras constituem uma atividade poderosa por meio da qual se inculca em seus participantes o que é ser parteira, condição para a conquista do reconhecimento do nawa. Isso é tão forte a ponto de aquelas que não participaram desses eventos, mas com ampla experiência em "pegar menino", não se autodefinirem como tal. Ao nomear as parteiras, os cursos também desautorizam as que não os frequentaram, aquelas que têm um saber prático e 'encorporado', a continuarem auxiliando suas parentas a parir. Esse processo pode instituir um sentimento de insegurança imobilizador. ${ }^{1}$ Afinal "os grupos dominantes consolidam a sua hegemonia, inculcando uma imagem de inferioridade nos grupos subjugados" (Taylor, 1994: 86).

Contratar parteiras significa instituir um processo de profissionalização. Sabe-se que, por mais indigenizado que seja o termo "profissional", acessado pelos discursos dos indígenas durante os encontros no Alto Juruá, a profissionalização 
requer um mínimo de domínio de leitura e escrita, assim como certo grau de escolarização. Na sociedade ocidental, o profissional não é "formado pela tradição", mas sim por um processo de aprendizado formal, oficialmente reconhecido pelo Estado. Assim, a profissionalização das parteiras, inevitavelmente, exigiria que as mulheres, para frequentar os cursos de qualificação básica, fossem letradas. Atualmente, esse processo está acontecendo também com os AISs que, apesar de ocuparem um cargo formal instituído pelo Estado, não são considerados profissionais se não concluírem todos os módulos de capacitação previstos pelo subsistema e não obtiverem o nível fundamental de escolarização, de acordo com a Medida Provisória n. 297/2006 (Brasil, 2006d), que regulamenta a profissão dos agentes comunitários de saúde.

De início, essa exigência deixaria de fora muitas mulheres com experiência prática em "pegar menino", mas que, além de muitas vezes falarem somente a língua indígena, são iletradas. Ou seja, nesse contexto, reconhecer as parteiras significa transformá-las por meio dos cursos de capacitação e validar cientificamente os conhecimentos tradicionais com os quais elas operam, a fim de depurá-los de qualquer resquício de cultura. Porém, essas mulheres não são parteiras justamente por terem sido formadas pela cultura? Nesse caso, que tipo de reconhecimento o Estado poderia dar a uma "profissional da cultura" se são justamente as características culturais da prática das parteiras que precisam ser depuradas? Assim, o poder colonial realiza o seu desejo de ver o Outro reformado, aqui concretizado em uma parteira quase-profissional - reconhecida e subordinada aos profissionais que atuam nos serviços públicos de saúde.

Novamente nos deparamos com a pergunta: quais serão os efeitos desencadeados sobre a organização comunitária dos cuidados com a saúde pautados em um sistema de dádiva, se tais reivindicações forem atendidas? No caso em que o conhecimento sobre o gestar e o parir é difuso e 'encorporado', como decidir quem vai ser contratada em meio a tantas mulheres com experiência prática em "pegar menino"? E as outras mulheres seriam desautorizadas a atuar na assistência aos partos, como já vem acontecendo em algumas comunidades dessa região desde o advento dos cursos de capacitação? No caso da profissionalização das parteiras, como contemplar as mulheres com ampla experiência prática em "pegar menino", mas sem domínio da escrita e tampouco do português? E, no caso em que a estrutura da assistência opera com as 'ajudantes da parteira', seriam contratadas as duas? Qual o impacto do processo de profissionalização sobre a organização sociocultural comunitária de assistência à gestação e ao parto? E quais os efeitos dos conhecimentos anatômicos e fisiológicos apreendidos pelas parteiras durante os cursos sobre o processo de fabricação de corpos e de pessoas indígenas, informado pelo idioma da substancialidade nos contextos comunitários?

De qualquer forma, um dos efeitos que inevitavelmente adviria com a contratação das parteiras seria sua subordinação aos profissionais - médicos e enfermeiros - que atuam nos serviços de saúde. Isso ocorreria porque contratar significa 
regulamentar o ofício da parteira, colocando-o sobre a vigilância administrativa do Estado. As antropólogas que atuaram na equipe de execução dos encontros no Alto Juruá, mesmo instigando os participantes indígenas a lutarem pelo reconhecimento profissional da parteira, acreditam que a contratação traria várias consequências para as comunidades indígenas dessa região.

Em primeiro lugar, pode se prever uma institucionalização da figura da parteira. (...) Se uma pessoa for contratada em cada comunidade para exercer esse cargo, as outras que normalmente desempenham essas atividades se negariam a continuar trabalhando sem receber remuneração. Se isso acontecer, pode-se prever uma maior afluência das mulheres à cidade para fazer o parto. Em segundo lugar, a transformação da função de "parteira" num cargo remunerado, o tornaria objeto de lutas políticas, de forma que em vez de serem escolhidas pessoas com aptidões para essa atividade, o critério usado seria a relação de parentesco com a liderança do momento. Sabemos que isso já acontece a respeito dos AIS e é possível percebêlo em relação às 'parteiras', já que algumas das participantes das reuniões foram escolhidas por suas respectivas comunidades para ocupar o cargo, apesar de não terem realizado partos, em detrimento de outras mulheres que o fizeram. Por último, a institucionalização da parteira por meio da contratação estaria sujeita à sua capacitação segundo os critérios e as técnicas biomédicas, o qual pode prejudicar o conhecimento e as práticas tradicionais indígenas. (Instituto Olhar Etnográfico, 2006b)

Os cursos de aperfeiçoamento das parteiras tradicionais indígenas têm gerado, nas mulheres indígenas do Acre, uma grande expectativa de serem contratadas e remuneradas pelo trabalho que realizam, ou que realizarão, como parteiras. Nesse caso, as reivindicações dos participantes dos encontros pela realização de outros cursos, assim como pela contratação das parteiras, sinônimo de reconhecimento normativo pelo Estado, também são legítimas. De fato, ter acesso aos conhecimentos biomédicos sobre os cuidados com a gestação, o parto e o pós-parto é um direito dos povos indígenas e, dependendo da forma como esse acesso for viabilizado, poderá contribuir de fato para a melhoria da situação da saúde materno-infantil indígena. Todavia, será preciso adequar os cursos às realidades sociomédicas indígenas e, para tanto, será necessário conhecer tais realidades comunitárias.

Por exemplo, nos contextos em que o saber sobre o gestar e o parir é difuso e de domínio das mulheres indígenas de determinada comunidade, por que, ao invés de se pensar em capacitação de parteiras, não se propiciam eventos que envolvam todas as mulheres da aldeia em um encontro intercultural de troca de conhecimentos e experiências junto a profissionais da saúde? Esses eventos pautados em uma metodologia de diálogo intercultural poderiam propiciar a construção de um saber comum e de rotinas de atenção baseada na cooperação e na articulação dos serviços de saúde aos sistemas indígenas de atenção ao parto. Certamente, 
assim se instituiriam relações menos assimétricas entre indígenas e não indígenas participantes desses eventos, de modo a qualificar a assistência prestada às comunidades indígenas e a consolidar o direito indígena de receber uma atenção diferenciada à sua saúde.

De fato, é preciso reconhecer que, em muitas situações, as mulheres que "pegam menino" trabalham em situações precárias. E, nesse contexto, o oficio de parteira pode se apresentar como uma fonte de renda que contribuiria não só para melhorar a qualidade da assistência, mas também permitiria que essas mulheres e suas famílias atendessem a algumas das suas necessidades e aos seus desejos de consumo pelas mercadorias do branco. No entanto, não necessariamente a contratação das parteiras seria a maneira mais adequada para se atender a essas necessidades. É preciso construir alternativas que deem conta dessa problemática. Mais do que cuidadores individuais, se faz necessário reconhecer o conjunto de saberes, práticas e praticantes que cuidam da gestação e do parto, ou seja, os sistemas indígenas de atenção ao parto, como um âmbito da assistência primária prestada à saúde materno-infantil indígena.

Dessa forma, faz-se necessário um conhecimento profundo e sistemático das condições com as quais operam os sistemas de parto indígenas nos contextos comunitários, bem como de suas interações com os serviços de saúde oferecidos a essas populações. Com base nesse conhecimento, as políticas públicas podem delinear um planejamento estratégico para a organização da atenção à saúde materno-infantil baseado na articulação com os saberes, as práticas e os cuidadores da saúde indígenas. As informações relativas à saúde materno-infantil a serem produzidas devem ser tanto quantitativas (epidemiológicas, demográficas, dos serviços) quanto qualitativas (etnográficas), dando conta dos distintos âmbitos da atenção prestada à saúde indígena - comunitárias, primária, de média e alta complexidades.

Assim, os cursos de capacitação de parteiras, por exemplo, deixariam de ser ações pontuais e passariam a integrar um programa elaborado com base em um conhecimento concreto da realidade, o que permitiria que eles fossem adequados para atender às demandas e às necessidades das comunidades, intervindo sobre os problemas de saúde reais previamente diagnosticados. Da mesma forma, eles devem ser ministrados por profissionais habilitados a dialogar com quem tenha diferentes perspectivas socioculturais a respeito do corpo, da concepção e dos cuidados com a saúde; aptos a construir conjuntamente conhecimentos a respeito dos processos de gestação e parto; e dispostos a acolher a verdade do outro, sem atribuir ao seu conhecimento científico o status de uma verdade universal. Sem conhecimento suficiente sobre as realidades socioculturais que informam a organização indígena dos cuidados com a gestação, o parto e o pós-parto, o discurso sobre a importância de respeitar o saber do Outro não passa de retórica, na medida em que não se respeita aquilo que não se conhece, ou melhor, que não se compreende. 
Outra linha de ação indicada pela AMTI, como evocado anteriormente, foi a de fortalecer as comunidades, construindo ferramentas, mediante um processo participativo, para que pudessem manter os seus próprios saberes, práticas, instituições e especialistas. Nesse caso, o foco do programa recairia na dimensão coletiva e comunitária dos povos indígenas, e não sobre praticantes individuais, visando a criar condições para a sustentabilidade econômica, ambiental e sociocultural das suas práticas de autoatenção tanto no sentido estrito quanto no sentido amplo. Isso requereria uma atuação coordenada dos diferentes setores que compõem o aparato administrativo do Estado.

Mais do que uma proposta concreta, acredito serem esses os pontos importantes a se considerar no processo de construção de uma política pública de atenção à saúde da mulher indígena, assim como na organização dos serviços de assistência à saúde materno-infantil indígena. Apenas se adotando uma postura reflexiva, dotada de consciência histórica, pode-se amenizar os riscos de se dar continuidade ao processo de colonização de corpos e de pessoas indígenas - efeito que a medicalização da gestação e do parto, dos cuidadores e da arte de partejar poderia desencadear por meio da realização dos cursos de capacitação dos praticantes das medicinas tradicionais indígenas.

1 "O reconhecimento incorreto não implica só uma falta do respeito devido. Pode também marcar as suas vítimas de forma cruel, subjugando-as através de um sentimento incapacitante de ódio contra elas mesmas. Por isso, o respeito (...) é uma necessidade humana vital" (Taylor, 1994: 46). 
Pretendeu-se, neste estudo, evidenciar a forma como a medicina tradicional indígena irrompe nos distintos locais que compõem o campo das políticas públicas em saúde indígena, assumindo sentidos e definições diferentes em cada uma das localidades. Por um lado os discursos oficiais transformam a medicina tradicional indígena em objetos de políticas públicas, por outro as vozes indígenas que aqui foram ouvidas, ao se reconhecerem em uma categoria discursiva que emerge no contexto das relações interétnicas estabelecidas com o Estado-nação, falam sobre os conhecimentos e práticas utilizados durante a gestação e o parto - tanto para manter a saúde e tratar os agravos quanto para produzir corpos e pessoas indígenas - que fazem parte dos seus sistemas de cuidados com a saúde. No primeiro caso, a medicina tradicional indígena é dita no singular; no segundo, revela-se a diversidade de formas que os cuidados com a saúde assumem nos contextos comunitários dos povos indígenas do Alto Juruá. Nesse âmbito, é mais apropriado falar em medicinas tradicionais indígenas, no plural.

Cada vez mais, o Estado brasileiro cria políticas públicas que empregam a noção de 'tradicional' para qualificar os seus objetos: medicina tradicional, povos e comunidades tradicionais, conhecimento tradicional (associado), práticas tradicionais (integrativas e complementares), parteiras tradicionais, entre outros. O discurso oficial veiculado por essas políticas está alinhado às diretrizes estipuladas pelos organismos internacionais (OMS, ONU, OIT) aos Estados nacionais, das quais o Brasil é signatário. O conjunto dessas políticas concorda com uma formação discursiva particular que aqui foi definida como políticas da tradição.

No campo da saúde, particularmente, a Organização Mundial da Saúde (OMS) recomenda aos países-membros a integração das medicinas tradicionais aos sistemas de saúde nacionais. Nos discursos oficiais, o estabelecimento de relações de cooperação entre esses sistemas e os praticantes das medicinas tradicionais se apresentaria como uma estratégia de baixo custo, de ampliação da cobertura e do acesso aos serviços de saúde por parte dos segmentos populacionais mais desfavorecidos em termos econômicos, principalmente nos países em desenvolvimento. 
Para que essa integração fosse possível, a OMS desenvolveu um conceito instrumental para a medicina tradicional (MT), sugerindo que algumas medidas fossem tomadas para garantir a segurança, a eficácia, a qualidade e seu uso racional. Com isso, o Estado exerceria o controle, por meio do aparato técnico-administrativo, sobre as práticas, os praticantes, os serviços e os produtos das medicinas tradicionais, passíveis de serem integradas aos sistemas oficiais de saúde. As políticas públicas brasileiras que tratam do tema aderiram tanto ao conceito desenvolvido pela OMS quanto às recomendações por ela postuladas. Dentre essas políticas estão a Política Nacional de Práticas Integrativas e Complementares (PNPIC), a Política Nacional de Plantas Medicinais e Fitoterápicos (PNPMF) e os projetos de lei dos deputados Eduardo Valverde e Janete Capibaribe.

Para que as medicinas tradicionais sejam integradas ao sistema oficial de saúde é necessário submetê-las a dois processos: a validação científica dos seus conhecimentos e das suas práticas; e a qualificação dos seus praticantes. Ao passo que o primeiro dá à ciência o papel de esquadrinhá-las, buscando depurá-las dos traços culturais ao produzir evidências científicas sobre a sua eficácia, a fim de validá-las, o segundo estabelece a necessidade de os praticantes serem devidamente qualificados em cursos que lhes disponibilizem conhecimentos básicos de saúde pública, tendo em vista a regulamentação do seu ofício. Aqui, regulamentar significa disciplinar e colocar essas práticas e praticantes sob a supervisão direta do Estado.

A validação científica está para as terapêuticas e produtos das medicinas tradicionais, assim como a qualificação, o credenciamento e o licenciamento estão para os seus praticantes. Nesse caso, o Estado-nação exerce o seu poder administrativo utilizando os seus dois modos de vigilância por excelência: a produção, o armazenamento e o controle das informações produzidas pela pesquisa científica; e a supervisão da qualidade dos produtos e dos serviços prestados pelos praticantes dessas medicinas. Essas medidas permitem que o Estado estenda o monitoramento reflexivo sobre dimensões do mundo da vida de povos e comunidades tradicionais que, até agora, se mantiveram à margem da vigilância exercida pelo seu aparato administrativo.

Além disso, ao criar políticas públicas para reconhecer e regulamentar os conhecimentos, práticas e praticantes 'tradicionais', o Estado exerce o poder simbólico da nomeação. Ao conceituar os objetos das políticas da tradição, o Estado, ao mesmo tempo, cria esses objetos ao nomeá-los e institui realidades socioculturais e políticas particulares nas quais intervém. Por outro lado, aqueles que não são contemplados por essas definições previamente estabelecidas são excluídos do escopo dessas políticas, pois não adquiriram condições de existência.

A partir do processo de produção colonial da diferença, o Estado define, por meio do seu poder de nomear, o que são as medicinas tradicionais, as práticas tradicionais, os povos e as comunidades tradicionais, as parteiras tradicionais, o 
conhecimento tradicional, assim como o que é ser índio, e o que é medicina tradicional indígena. As políticas públicas, geralmente, são elaboradas com base na fantasia da diferença colonial, que ao mesmo tempo reforça e subordina os grupos sociais, obrigando-os a imitar aquelas imagens fantasmáticas da civilidade ou da cidadania. Como diz Bhabha (2005), o Estado precisa produzir diferenciações, por meio das quais as práticas discriminatórias possam mapear as populações a serem submetidas ao seu poder administrativo.

Entretanto, ao instituir tais definições, os discursos oficiais deixam de contemplar as múltiplas conceituações que essas categorias apresentam nos contextos socioculturais dos povos e comunidades que constituem o alvo dessas políticas. Nesse sentido, as políticas públicas acabam por operar com noções estereotipadas do que são os seus objetos qualificados pela tradição. Assim, os conceitos operacionalizados por essas políticas não deixam de se constituir em dispositivos do poder colonial que instituem uma forma fixa de representação, transformando diferenças culturais em estereótipos. No caso das medicinas tracionais, essa fixidez está associada à ideia de que seus saberes e suas práticas provêm de tempos imemoriais, mantendo-se imutáveis, portanto, fixos e estáticos, no seu processo de transmissão por sucessivas gerações. Além disso, essas medicinas também encerram algo de atrasado e de supersticioso, precisando ser aperfeiçoadas pela ciência moderna, de modo a se tornarem um recurso eficaz de atenção primária à saúde.

A formação discursiva das políticas da tradição se organiza em torno da dicotomia modernidade versus tradição. Ao operar com essa dicotomia, os discursos oficiais acabam por subordinar os saberes locais e culturais ao modelo biomédico universalista. Nesse contexto, a ciência instaura um processo de neocolonização cultural dos saberes dos grupos socialmente subordinados, e é isso o que possibilita torná-los objetos de políticas públicas. Entretanto, convém lembrar que o Estado não está inclinado a incorporar toda e qualquer prática das medicinas tradicionais (MTs), mas somente aquelas que podem ser apreendidas pela racionalidade biomédica, como, por exemplo, o uso de plantas medicinais como previsto na PNPMF.

Reconhecer oficialmente as medicinas tradicionais significa validá-las cientificamente, torná-las seguras e eficazes, transformá-las em universais. Como visto anteriormente, não se valida uma prática apenas por seu caráter tradicional. Para que ela seja reconhecida, é necessário submetê-la ao escrutínio da ciência. Portanto, a tradição que qualifica os objetos das políticas públicas precisa ser forjada por essas mesmas políticas, o que não deixa de ser um fenômeno característico da modernidade: a tradição como objeto de políticas públicas é um constructo moderno instituído pelas organizações típicas da modernidade - os organismos internacionais e o Estado-nação.

Os processos de validação científica e qualificação profissional dos praticantes das MTs têm a virtude de deslocar conhecimentos, práticas e agentes sociais 
de seus contextos locais e reencaixá-los no espaço das políticas públicas, no qual eles adquirem sentidos e valores diferentes dos que tinham originalmente, agora associados à ideia de inclusão social e cidadania constitutiva do Estado moderno brasileiro. Nesse caso, para reconhecer/valorizar/validar a tradição, que organiza o mundo da vida dos povos e comunidades tradicionais, é preciso transformá-la em objetos deslocados de políticas públicas. Esses objetos deslocados são os híbridos culturais que emergem com o processo de ocidentalização instaurado pelo Estado ao cientificizar os conhecimentos, as práticas, os povos e as comunidades tradicionais, tratados como assuntos de interesse nacional e de preocupações internacionais. Dessa forma, os discursos oficiais constroem objetos híbridos de políticas públicas sustentados sobre a retórica da tradicionalidade.

Em síntese, a integração das medicinas tradicionais ao sistema oficial de saúde requer a observância de diferentes etapas: a identificação de terapias e recursos úteis e eficazes, do ponto de vista biomédico; a descontextualização de práticas, saberes e praticantes; a validação científica/qualificação das medicinas tradicionais; o reencaixe desses saberes, práticas e praticantes no contexto universal das políticas públicas; e a mercantilização do tradicional.

Nesse processo, as medicinas tradicionais se transformam em serviços e produtos complementares, colocados à disposição do cidadão-usuário do Sistema Único de Saúde (SUS) ou do cidadão-consumidor. Ou seja, a regulamentação das MTs pelas políticas públicas também autoriza que os seus conhecimentos e suas práticas sejam mercantilizados, na medida em que eles adquirem um estatuto de universal ao serem validados cientificamente. Assim, as terapêuticas das MTs poderão ser comercializadas tanto como produtos quanto como serviços disponibilizados aos cidadãos e consumidores do mercado da saúde.

Contudo, ao irromperem nos contextos locais, os discursos oficiais das políticas públicas reordenam as relações sociais, conectando-as a uma ordem mundial mais abrangente. No caso aqui analisado, os discursos oficiais permitiram a criação da Área de Medicina Tradicional Indígena (AMTI) do Projeto Vigisus II - um espaço fronteiriço situado entre as relações do governo brasileiro com um organismo internacional - o Banco Mundial -, por um lado, e entre essas organizações mundialmente difundidas e os povos indígenas localmente situados, por outro.

Dessa forma, os encontros entre parteiras, pajés e agentes indígenas de saúde (AISs) que aconteceram na região do Alto Juruá, como atividades fomentadas pela AMTI, também são exemplares do processo de irrupção de políticas públicas em contextos locais. Gestadas em um lugar distante e tendo ocorrido em localidades particulares reordenando as relações sociais, esses encontros assumiram uma configuração translocal (Ayora Diaz, 2007). Apesar de a AMTI, por meio do discurso que veicula, propor uma reflexáo crítica sobre os efeitos colonizadores e de medicalização causados pela implantação de uma política pública específica 
- os cursos de capacitação de parteiras - sobre os corpos e a vida das comunidades indígenas, convém dizer que, nesse caso, a existência de tal política se deve justamente às possibilidades instituídas pelos discursos oficiais relativos tanto às medicinas tradicionais quantos aos direitos socioculturais dos povos indígenas.

Também é preciso considerar que o contexto em que aconteceram os encontros do Alto Juruá já havia acolhido outras ações vinculadas a políticas públicas específicas. Essas ações, por sua vez, também influenciaram tanto a configuração das realidades socioculturais indígenas dessa região quanto a conformação dos discursos veiculados pelos agentes que estiveram presentes nesses eventos comunicativos.

No entanto, o que os enunciados proferidos durantes esses encontros permitem perceber é que os discursos, categorias, conhecimentos e bens disponibilizados pelas políticas públicas são apropriados pelos povos indígenas do Alto Juruá e submetidos a um processo de indigenização. Nesse processo, esses discursos também são transformados de modo a atender a interesses indígenas de developman (Sahlins, 1997a) e de reprodução sociocultural. Portanto, esses discursos indigenizados passam a veicular outros sentidos, diferentes daqueles que originalmente eles têm como políticas públicas.

Esse é o caso dos cursos de aperfeiçoamento das parteiras tradicionais indígenas que constituíram um desdobramento de uma política pública específica do Ministério da Saúde - o Programa Trabalhando com as Parteiras Tradicionais. Essa política, alinhada às recomendações da OMS para a integração colaborativa das parteiras tradicionais aos serviços de saúde, está sendo implantada no estado do Acre por meio da parceria estabelecida entre o Ministério da Saúde e a organização não governamental (ONG) Grupo Curumim. Além disso, o Projeto de Lei n. 2.145/2007, da deputada Janete Capibaribe, materializa as intencionalidades governamentais de regulamentação desse ofício (Brasil, 2007b).

As falas dos participantes dos encontros do Alto Juruá revelaram o quanto os conhecimentos e as coisas do kit parteira, consequentemente, os próprios cursos, foram apropriados pelas comunidades e povos indígenas dessa região e submetidos a um processo de indigenização por meio do qual, ao serem colocados a serviço dos seus interesses de desenvolvimento, adquiriram sentidos e funções diferentes daqueles originalmente estabelecidos pelas políticas públicas. Entretanto, mesmo esvaziados em seu conteúdo semântico, ao atravessarem as fronteiras da diferença cultural, os conhecimentos e as coisas apropriados ainda apresentam algo de sua sociedade de origem.

Um dos efeitos dessa apropriação foram, justamente, as mudanças na forma tradicional de assistência aos partos, como era feita antes do advento dos cursos - o chamado "parto tradicional" -, para o modo como ela é feita atualmente: as parteiras passaram a usar em sua prática os procedimentos e materiais apreendidos durante 
os cursos. Além disso, os discursos indicam que a própria organização sociocultural dos cuidados prestados à gestação e ao parto vem sofrendo alterações com a introdução dos valores do sistema oficial de saúde veiculados pelos cursos, tais como o da intimidade e da privacidade que informam a orientação dada às parteiras de que atuem contando apenas com a colaboração de uma auxiliar. Como já mencionado, na descrição apresentada por Lagrou (2007), pelo menos entre os Kaxinawa, vários parentes próximos da grávida participam do evento de parto e cumprem funções específicas no processo de cuidado e de produção do novo ser que chega ao mundo.

Se, por um lado, essas transformações foram marcadas pela introdução dos materiais do kit parteira na prática do "pegar menino". Por outro, a transformação mais radical que esses discursos permitem perceber foi a própria emergência da parteira como alguém habilitado para acompanhar as gestantes e assistir os partos, principalmente nos contextos comunitários, onde os conhecimentos e práticas de autoatenção relacionados ao processo de gestar e parir são 'encorporados', portanto difusos e compartilhados por todas aquelas que, ao estarem vinculadas pelos laços do parentesco, já passaram por essa experiência. O mesmo se dá também naquelas aldeias em que a figura da parteira já existia como referência na assistência aos partos e que tiveram a sua prática transformada pelos conhecimentos e materiais apreendidos nos cursos.

Portanto, ou a figura da parteira tradicional surge com o advento dos cursos, como em algumas comunidades Kaxinawa e entre os Katukina, ou ela é transformada por esses cursos na medida em que a sua prática da parteira também o é, no caso dos demais povos dessa região. De qualquer forma, o fenômeno de emergência da "parteira capacitada" e da instituição do cargo de parteira nas aldeias resulta tanto do efeito desses cursos quanto do exercício da agência indígena ao se apropriarem deles.

Os cursos de parteiras são percebidos como um caminho através do qual se vai conquistar o reconhecimento profissional das parteiras indígenas e a consequente contratação remunerada pelo Estado. Até mesmo porque têm um poder criador: o poder de nomear as parteiras tradicionais e reordenar as relações socioculturais de cuidados com a gestação e o parto no âmbito das comunidades indígenas do Alto Juruá. Isso foi evidenciado quando as reivindicações pela contratação remunerada das parteiras e dos pajés surgiram nos encontros do Alto Juruá como uma das dimensões da luta indígena pela conquista do reconhecimento.

Todavia, o problema do reconhecimento tem duas faces: o reconhecimento interno das comunidades para com a atuação das parteiras; e o reconhecimento externo, normativo, advindo do Estado, que se materializaria na contratação remunerada das parteiras indígenas. Se isso acontecer, provavelmente os cuidados com a gestação e o parto, que originalmente se encontram inscritos em um sistema de dádiva, serão deslocados para um regime de Estado. Com a instauração desse 
processo, passa a existir uma redefinição dos papéis dos diferentes especialistas e, consequentemente, uma reordenação das relações sociais que acontecem no âmbito comunitário. Ao mesmo tempo, a concepção de saúde e bem-estar tem seu foco totalmente modificado, do sentido amplo para o sentido estrito que informa as práticas de autoatenção.

A promoção desses cursos, na verdade, encontra-se em consonância com os discursos oficiais, que recomendam a qualificação dos praticantes das medicinas tradicionais de modo a integrá-los aos sistemas de saúde nacionais, tornando-os colaboradores dos serviços. Entretanto, se o reconhecimento profissional só pode advir da validação científica das práticas e da sua qualificação, as parteiras somente poderão exercer o seu oficio ao serem deslocadas do âmbito comunitário para integrar os quadros burocráticos da administração pública. No âmbito comunitário, a atuação das parteiras ainda está sustentada pelo reconhecimento da comunidade. Talvez esse tenha sido o motivo de algumas "parteiras capacitadas" reclamarem que, mesmo tendo sido treinadas, em sua comunidade, as mulheres continuam preferindo recorrer às suas mães ou mesmo terem sozinhas seus filhos.

Dessa forma, o movimento desencadeado pelas políticas públicas, ao tornar as coisas e os sujeitos do tradicional seus objetos, é circular, pois os povos indígenas se reapropriam desses objetos de acordo com seus próprios pontos de vista e lhes atribuem outros sentidos, não mais os originais, mas também não exatamente aqueles veiculados pelos discursos oficiais. As diferenças culturais são redimensionadas e novos locais de cultura emergem a partir das relações estabelecidas entre os povos indígenas e o Estado.

É importante dizer que as políticas públicas relacionadas à saúde indígena, em especial as que se direcionam aos cuidados com a gestação e o parto, são inscritas nos corpos dos sujeitos indígenas, os quais constituem o suporte central da organização dos sistemas de parentescos ameríndios. Portanto, elas impactam tanto a organização sociocultural dos cuidados com as gestantes e parturientes, tendo como um dos seus efeitos a emergência dos agentes intermédicos de cuidado com a saúde - os AISs e as parteiras -, quanto as práticas de assistência ao parto e as formas de parir.

O fato de a "parteira capacitada" ser emergente no Alto Juruá e, portanto, um constructo moderno, não desqualifica a luta indígena pelo seu reconhecimento e pela realização de outros cursos de parteiras, já que, por meio deles, as comunidades dessa região teriam acesso aos conhecimentos e às coisas do branco, bem como aos recursos e benefícios advindos da relação com o Estado, que poderiam melhorar tanto as suas condição de trabalho quanto as de vida. Entretanto, essa questão deve ser objeto de reflexões aprofundadas que busquem alternativas para a criação de condições de operacionalização dos sistemas de partos tradicionais, prevendo os riscos que o desenvolvimento de uma ação governamental irrefletida, 
o papel do AIS também foi indigenizado e, assim, sua figura também emerge nos discursos indígenas.

Mas os agentes envolvidos nesses cuidados, vinculados por laços de parentesco, agem de forma complementar no contexto das relações de gênero que fabricam corpos e produzem pessoas indígenas. Cada um dos cuidadores das gestantes, das parturientes e dos recém-nascidos, sejam familiares, sejam especialistas, apresenta capacidades específicas, associadas à sua identidade de gênero, que contribuem para o sucesso do empreendimento gestacional. Todavia, a agência da gestante, ao decidir quais os cuidados irá observar e quais os cuidadores irá acessar para ajudála a parir, é central para articular os diferentes especialistas e recursos de saúde.

Se os cursos de parteiras constituíram espaços fronteiriços do encontro colonial que possibilitaram as apropriações indígenas dos conhecimentos e das coisas dos brancos e a articulação das diferenças culturais ali representadas, os encontros entre parteiras, pajés e AISs também constituíram eventos socialmente situados que propiciaram o contraste entre diferenças étnicas e culturais. Porém, ao passo que os primeiros apresentam o status de capacitação, no qual alguns têm a função de repassar conhecimentos, e outros de apreendê-los, os encontros apresentam o status de troca de experiências em que as relações, mesmo que ainda pautadas em princípios hierárquicos, foram estabelecidas em um eixo mais horizontal (ou menos vertical).

Os participantes desses eventos, ao se encontrarem em uma situação dialógica, revisaram os sentidos atribuídos à função, aos conhecimentos e às práticas das parteiras, dos pajés e dos AISs de modo a recriá-los em um contínuo processo de autopoiesis. Dos seus discursos, emergiram os sentidos atribuídos aos saberes e práticas usados nos cuidados com a gestação e na assistência ao parto, bem como aos papéis desempenhados pelas parteiras, pajés e AISs no cuidado com as grávidas e as parturientes nos múltiplos contextos comunitários dessa região. Também emergiram, nesse contexto, os sentidos das categorias medicina tradicional indígena, pré-natal tradicional e cultura, entre outras.

Os discursos dos participantes indígenas operaram com uma série de dicotomias organizadas em torno da oposição índios versus brancos que, por sua vez, instaura um corte temporal entre os tempos de antigamente e os dias atuais. Entre as dicotomias que emergiram nos discursos, citam-se algumas: conhecimento tradicional versus conhecimento do branco; parto tradicional versus forma do branco de fazer partos, marcada pelos procedimentos de higiene e pelo uso dos materiais do kit parteira; pré-natal indígena versus pré-natal do branco; parto antigamente versus parto hoje; remédio da farmácia versus remédio tradicional; medicina tradicional versus medicina do branco; parteira indígena versus parteira branca (enfermeira); pajé versus médico, e assim por diante. Aparentemente, tais pares de opostos fazem parte de uma dicotomia discursiva mais fundamental, aquela entre cultura/tradição 
indígena e mundo do branco, que faria frente à dicotomia estruturante dos discursos das políticas públicas sustentados sobre a oposição entre modernidade e tradição.

Uma das categorias discursivas que emergiram durante os encontros do Alto Juruá foi "pré-natal tradicional", utilizada pelos participantes para se referir aos cuidados indígenas observados durante a gestação: dietas, folhas, rezas, condutas e emoções. Essa noção foi empregada tanto como um meio de contrastar o pré-natal realizado pelos serviços de saúde e os cuidados utilizados pelos indígenas quanto como uma forma de dizer para o branco que os povos indígenas representados também tinham a sua própria forma de cuidar da gestação. De qualquer maneira, a noção de pré-natal, originariamente usada no contexto dos serviços públicos de saúde para se referir a um conjunto de procedimentos e exames padronizados e realizados pelo Estado para garantir uma gestação e um parto seguros, foi apropriada pelos povos indígenas e submetida ao processo de indigenização, tornando-se o 'pré-natal indígena'.

É nesse contexto discursivo que a noção de medicina tradicional foi colocada em debate, fazendo com que suas definições emergissem do próprio diálogo instaurado entre os participantes, quando eles confrontaram os diferentes entendimentos sobre o tema e construíram uma compreensão compartilhada. Geralmente, o sentido preponderante atribuído a essa noção foi o associado ao uso dos 'remédios da mata'. Nesse caso, a medicina tradicional está muito mais alinhada ao sentido estrito das práticas de autoatenção, que se referem ao processo saúde-enfermidade-atenção. Entretanto, ao contemplar práticas que contribuem para a produção de corpos e pessoas indígenas na medicina tradicional, também se opera com a dimensão ampla das práticas de autoatenção, empregadas para assegurar a reprodução biossocial e cultural dos povos indígenas do Alto Juruá.

De qualquer forma, os sentidos que informam a noção de medicina tradicional como utilizada pelos povos indígenas são diferentes daqueles veiculados pelos discursos oficiais. Nestes, predomina um conceito que destaca a fixidez dos conhecimentos e práticas tradicionais, ao passo que entre os povos indígenas, a noção de tradição é utilizada para demarcar a diferença do modo de ser e de fazer do branco. Aqui se está diante de um paradoxo: se, nos discursos oficiais, opera-se com uma noção estereotipada da medicina tradicional, as vozes indígenas falam do seu caráter dinâmico e incompleto. E, nesse caso, a tradição se encontra em permanente revisão, de modo a propiciar a emergência de novos conhecimentos e novas práticas, como explica uma anciã indígena: quando um remédio da mata não dá certo, ela tenta outro até encontrar a solução para o problema. Entretanto, essas vozes também retroalimentam os discursos oficiais de maneira a atualizá-los.

Portanto, a emergência das categorias medicina tradicional indígena, conhecimento tradicional, parteiras tradicionais etc. acontece em uma via de mão dupla: tanto os objetos das políticas públicas qualificados pela noção de tradicional 
quanto as categorias discursivas utilizadas pelos participantes dos encontros do Alto Juruá são híbridos. Só que, em cada local de cultura, essas categorias adquirem sentidos e funções diferentes. No caso da medicina tradicional como objeto das políticas públicas, por exemplo, vigora o conceito instrumentalizado que permite a integração de algumas das suas práticas e praticantes - passíveis de serem reconhecidos pelo modelo médico hegemônico - ao sistema oficial de saúde. Já entre os povos indígenas do Alto Juruá, as práticas e os cuidadores comunitários da saúde operam em contextos comunitários e de parentesco com conhecimentos práticos inscritos em seus próprios corpos. Se a medicina tradicional é 'encorporada' nos contextos comunitários dos povos indígenas do Alto Juruá, no âmbito dos discursos oficiais ela é fragmentada em seus princípios constitutivos para assumir o status de objeto das políticas públicas, nesse caso, 'descorporado'.

Contudo, toda essa reflexão somente pode ser realizada porque estou situada no espaço fronteiriço da Área de Medicina Tradicional Indígena, ocupando uma posição de entremeio - a gestão. Foi a área que possibilitou o deslocamento de diversos agentes - principalmente lideranças indígenas e antropólogos - entre o âmbito nacional e os múltiplos locais em que ocorreram os encontros entre parteiras, pajés e AISs. Assim, a AMTI propiciou a irrupção dos discursos oficiais nas diferentes localidades onde transcorreram os eventos comunicativos por ela promovidos. Nesse caso, os antropólogos e as lideranças indígenas que compuseram a equipe de execução das ações atuaram como agentes translocais que, por transitarem entre as fronteiras da diferença cultural, estabeleceram conexões particulares de modo a contribuir para instituir realidades translocais e fazer emergirem esses eventos comunicativos como novos locais de cultura.

No processo de desenvolvimento das atividades da AMTI, os antropólogos ocuparam diferentes posições: consultor, assessor, colaborador, gestor. Suas reflexões e seus discursos foram conformados pelas posições por eles ocupadas - às vezes mais acadêmicas, às vezes mais implicadas. Cada posição ocupada possibilitou, por sua vez, que diferentes reflexões fossem desenvolvidas sobre o mesmo fenômeno. Ou seja, múltiplos são os lugares em que os antropólogos atualmente estão situados no exercício de seu ofício. Cada um deles abre possibilidades de produção de conhecimentos específicos que só se torna possível se o antropólogo estiver ocupando determinada posição no campo.

Dessa forma, o fenômeno de emergência de novos locais de cultura propiciados pela articulação das diferenças culturais em um contexto mundial globalizado requer também novos lugares do fazer antropológico. E o lugar de gestão é uma das posições possíveis na qual conhecimentos e reflexões podem e devem ser produzidos. 


\section{Referências}

ALBERT, B. Cosmologias do contato no Norte-Amazônico. In: ALBERT, B. G RAMOS, A. R. (Orgs.). Pacificando o Branco: cosmologias do contato no Norte-Amazônico. São Paulo: Editora Unesp, Imprensa Oficial do Estado, 2002.

AQUINO, T. T. V. Kaxinawá do Rio Jordão: história, território, economia e desenvolvimento sustentado. Rio Branco: Comissão Pró-Índio do Acre, 1994.

ATHIAS, R. Medicina indígena no Rio Negro: experiência de um projeto. In: FERREIRA, L. O. G OSÓRIO, P. (Orgs.). Medicina Tradicional Indígena em Contextos. Reunião de Monitoramento, 1, 2007, Brasília. Anais... Brasília: Projeto Vigisus II, Funasa, 2007.

AYORA DIAZ, S. I. Translocalidad y antropología de los procesos globales: saber y poder en Chiapas y Yucatán. Journal of Latin American and Caribbean Anthropology, 12(1): 134-163, 2007.

BAKHTIN, M. The problem of speech genres, In: EMERSON, C.GHOLQUIST, M. (Eds.). Speech Genres an Other Late Essays. Austin: University of Austin Press, 1980.

BHABHA, H. K. O Local da Cultura. Belo Horizonte: Editora UFMG, 2005.

BOURDIEU, P. Razões Práticas: sobre a teoria da ação. Campinas: Papirus, 1996.

BOURDIEU, P. O Poder Simbólico. Rio de Janeiro: Bertrand Brasil, 2005.

BRASIL. Lei n. 8.080, de 19 de set. 1990. Dispõe sobre as condições para a promoção, proteção e recuperação da saúde, a organização e o funcionamento dos serviços correspondentes e dá outras providências. Diário Oficial, Brasília, 20 set. 1990. Disponível em: <www. planalto.gov.br/ccivil_03/Leis/L8080.htm>. Acesso em: 20 set. 2009.

BRASIL. Decreto n. 3.156, de 27 de ago. 1999. Dispõe sobre as condições para a prestação de assistência à saúde dos povos indígenas, no âmbito do Sistema Único de Saúde, pelo Ministério da Saúde, altera dispositivos dos Decretos n. 564, de 8 jun. 1992, e 1.141, de 19 maio 1994, e dá outras providências. Diário Oficial, Brasília, 28 ago. 1999a. Disponível em: <www.planalto.gov.br/ccivil_03/decreto/D3156.htm>. Acesso em: 20 set. 2009 .

BRASIL. Lei n. 9.836, de 23 set. 1999. Acrescenta dispositivos à Lei n. 8.080, de 19 set. 1990, que 'dispõe sobre as condições para a promoção, proteção e recuperação da saúde, a organização e o funcionamento dos serviços correspondentes e dá outras providências', instituindo o Subsistema de Atenção à Saúde Indígena. Diário Oficial, Brasília, 24 set. 1999b. Disponível em: <www.planalto.gov.br/ccivil_03/Leis/L9836. htm >. Acesso em: 20 set. 2009. 
BRASIL. Ministério da Saúde. Livro da Parteira. Brasília: Ministério da Saúde, 2000.

BRASIL. Medida provisória n. 2.186-16, de 23 ago. 2001. Regulamenta o inciso II do $\S 1^{\circ}$ e o $\$ 4^{\circ}$ do art. 225 da Constituição, os arts. $1^{\circ}, 8^{\circ}$, alínea ' 'j', 10, alínea ' $c^{\prime}, 15$ e 16 , alíneas 3 e 4 da Convenção sobre ao Diversidade Biológica, dispõe sobre o acesso ao patrimônio genético, a proteção e o acesso ao conhecimento tradicional associado a repartição de benefícios e o acesso à tecnologia e transferência de tecnologia para a sua conservação e utilização, e dá outras providências. Em tramitação. Diário Oficial, Brasília, 24 ago. 2001. Disponível em: <www.planalto.gov.br/ccivil_03/MPV/2186-16. htm>. Acesso em: 20 set. 2009.

BRASIL. Ministério da Saúde. Funasa. Política Nacional de Atenção à Saúde dos Povos Indígenas. Brasília: Ministério da Saúde, 2002.

BRASIL. Projeto de Lei n. 5.078/2005, do deputado Eduardo Valverde. Estabelece e regulamenta os mecanismos para a proteção, promoção, reconhecimento e exercício da medicina tradicional, das Terapias Complementares (TCs) e do patrimônio biogenético das populações indígenas, 2005a. Disponível em: <www.camara.gov.br/proposicoesWeb/ prop_mostrarintegra;jsessionid =129266B28088CD915FAA166A6B2C98B3.node2?codteor $=300413$ Gfilename $=$ Tramitacao-PL $+4842 / 1998>$. Acesso em: 20 set. 2009.

BRASIL. Lei n. 11.108, de 07 abr. 2005. Altera a Lei n. 8.080, de 19 de set. de 1990, para garantir às parturientes o direito à presença de acompanhante durante o trabalho de parto, parto e pós-parto imediato, no âmbito do Sistema Único de Saúde - SUS. Diário Oficial, Brasília, 8 abr. 2005b. Disponível em: <www.planalto.gov.br/ccivil_03/_Ato20042006/2005/Lei/L11108.htm>. Acesso em: 20 set. 2009.

BRASIL. Ministério da Saúde. Manual Técnico de Pré-Natal e Puerpério: atenção qualificada e humanizada. Brasília: Ministério da Saúde, 2006a.

BRASIL. Ministério da Saúde. Política Nacional de Plantas Medicinais e Fitoterápicos. Brasília: Ministério da Saúde: 2006b.

BRASIL. Ministério da Saúde. Política Nacional de Práticas Integrativas e Complementares. Brasília: Ministério da Saúde, 2006c.

BRASIL. Medida Provisória n. 297, de 9 jun. 2006. Regulamenta o § 5o do art. 198 da Constituição, dispõe sobre o aproveitamento de pessoal amparado pelo parágrafo único do art. $2^{\circ}$ da Emenda Constitucional n. 51, de 14 de fevereiro de 2006, e dá outras providências. Diário Oficial, Brasília, 12 jun. 2006d. Disponível em: <www.camara.gov.br/ proposicoesWeb/prop_mostrarintegra;jsessionid=15860C0153D92A670F301087F6DFAC8E.node1 ?codteor $=402772$ Gfilename $=M P V+297 / 2006>$. Acesso em: 20 set. 2009.

BRASIL. Ministério do Desenvolvimento Social. Política Nacional de Povos e Comunidades Tradicionais. Brasília: Ministério do Desenvolvimento Social, 2007a.

BRASIL. Projeto de Lei n. 2.145/2007, da deputada federal Janete Capiberibe. Regulamenta a profissão das parteiras tradicionais no Brasil, 2007b. Disponível em: <www. camara.gov.br/proposicoesWeb/prop_mostrarintegra?codteor $=5094026$ filena$\mathrm{me}=\mathrm{PL}+2145 / 2007>$. Acesso em: 20 set. 2009.

BRASIL. Decreto n. 6.040, de 7 fev. 2007. Institui a Política Nacional de Desenvolvimento Sustentável dos Povos e Comunidades Tradicionais. Diário Oficial, Brasília, 8 fev. 2007c. Disponível em: < www.planalto.gov.br/ccivil_03/_Ato2007-2010/2007/Decreto/D6040. htm>. Acesso em: 20 set. 2009. 
CAILLÉ, A. Reconhecimento e sociologia. Revista Brasileira de Ciências Sociais, 23(63): 151-163, 2008.

CANCLINI, N. G. Culturas Híbridas. São Paulo: Edusp, 2003.

CARDOSO DE OLIVEIRA, R. G OLIVEIRA, L. R. C. Ensaios Antropológicos sobre Moral e Ética. Rio de Janeiro: Tempo Brasileiro, 1996.

CARNEIRO DA CUNHA, M. Cultura com Aspas. São Paulo: Cosac Naify, 2009.

Charaudeau, P. G MAIngueneaU, D. Dicionário de Análise de Discurso. São Paulo: Contexto, 2006.

CONKLIN, B. Shamans versus pirates in the Amazonian treasure chest. American Anthropologist, 104(4): 1.050-1.061, 2002.

COSTA, M. S. G SOUSA, T. O. Adesão ao Pré-Natal: a reprodução de um conceito, 2002. Monografia de Conclusão de Curso, Goiânia: Curso de Enfermagem. Universidade Católica de Goiás.

CRAPANZANO, V. Diálogo. Revista Anuário Antropológico, 88: 59-80, 1991.

DALLARI BUCCI, M. P. Políticas Públicas: reflexões sobre o conceito jurídico. São Paulo: Saraiva, 2006.

DESHAYES, P. G KEIFENHEIM, B. Penser l'Autre chez les Indians Huni Kuin de l'Amazonie. Paris: L'Harmattan, 1994.

ERIKSON, P. Uma singular pluralidade: a etno-história pano. In: CUNHA, M. C. (Org.). História dos Índios no Brasil. São Paulo: Cia das Letras, 1992.

ERIKSON, P. Reflexos de si, ecos de outrem. Efeitos do contato sobre a auto-representação Matis. In: ALBERT, B. G RAMOS, A. R. (Orgs.). Pacificando o Branco: cosmologias do contato no Norte-Amazônico. São Paulo: Editora Unesp, Imprensa Oficial do Estado, 2002.

FERREIRA, L. O. Projeto Valorização e Adequação dos Sistemas de Parto Tradicionais das Etnias do Acre e do Sul do Amazonas. Produto de consultoria Pnud, Projeto Vigisus II. Brasília, 2004 (Área de Medicina Tradicional Indígena).

FERREIRA, L. O. Entre Discursos Oficiais e Vozes Indígenas sobre Gestação e Parto no Alto Juruá: a emergência da medicina tradicional indígena no campo das políticas públicas, 2010. Tese de Doutorado, Florianópolis: Centro de Filosofia e Ciências Humanas, Universidade Federal de Santa Catarina.

FERREIRA, L. O. G OSÓRIO, P. Medicina tradicional indígena em contextos. In: REUNIÃO DE MONITORAMENTO, 1, 2007, Brasília. Anais... Brasília: Projeto Vigisus II, Funasa, 2007.

FOLLÉR, M.-L. Intermedicalidade: a zona de contato criada por povos indígenas e profissionais de saúde. In: LANGDON, E. J. G GARNELO, L. (Orgs.). Saúde dos Povos Indígenas: reflexões sobre antropologia participativa. Rio de Janeiro: Contracapa, ABA, 2004.

FOUCAULT, M. Microfísica do Poder. Rio de Janeiro: Edições Graal, 1979.

FOUCAULT, M. A Arqueologia do Saber. Rio de Janeiro: Forense Universitária, 2005.

FUNDAÇÃO NACIONAL DE SAÚDE (FUNASA). Educação Profissional Básica para Agentes Indígenas de Saúde: módulo introdutório. Brasília: Fundação Nacional de Saúde, 2005. 
GALLOIS, D. Nossas falas duras: discurso político e autorrepresentação Waiãpi. In: ALBERT, B. G RAMOS, A. R. (Orgs.). Pacificando o Branco: cosmologias do contato no Norte-Amazônico. São Paulo: Editora Unesp, Imprensa Oficial do Estado, 2002.

GARNELO, L. Medicina tradicional Baniwa: uma experiência de intervenção social em busca de uma teoria. In: GARNELO, L. G LANGDON, E. J. (Orgs.). Saúde dos Povos Indígenas: reflexões para uma antropologia participativa. Rio de Janeiro: Contracapa, 2004a.

GARNELO, L. Políticas de Saúde dos Povos Indígenas no Brasil: análise situacional do período de 1990 a 2004. Porto Velho, Rio de Janeiro: Centro de Estudos de Saúde do Índio/Universidade Federal de Rondônia, Escola Nacional de Saúde Pública Sérgio Arouca/Fiocruz, 2004b. Disponível em: <www.cesir.unir.br/pdfs/doc9.pdf> . Acesso em: 17 out. 2009.

GEERTZ, C. A Interpretação das Culturas. Rio de Janeiro: LTC, 1989.

GIDDENS, A. As Consequências da Modernidade. São Paulo: Editora Unesp, 1991.

GIDDENS, A. O Estado-Nação e a Violência. São Paulo: Edusp, 2008.

GODELIER, M. O Enigma do Dom. Rio de Janeiro: Civilização Brasileira, 2001.

GOUDBOUT, J. T. O Espírito da Dádiva. Rio de Janeiro: Editora FGV, 1999.

GOW, P. Of Mixed Blood: kinship and history in Peruvian Amazonia. New York: Clarendon Press-Oxford, 1991.

GREENE, S. The shaman's needle: development, shamanic agency, and intermedicality in Aguaruna Lands, Peru. American Ethnologist, 25(4): 634-658, 1998.

GRUPO DE MULHERES INDÍGENAS (GMI). Projeto Parteiras Indígenas do Acre. Rio Branco, 2004a.

GRUPO DE MULHERES INDÍGENAS (GMI). Relatório de atividades dos cursos de aperfeiçoamento de parteiras tradicionais indígenas, Alto Juruá (Acre). Relatório de pesquisa. Rio Branco, 2004b.

INSTITUTO OLHAR ETNOGRÁFICO. Relatório de atividades ( $1^{\circ}$ produto): dezembro de 2005 a março de 2006. Projeto valorização e adequação dos sistemas de partos tradicionais das etnias indígenas do Acre e do Sul do Amazonas. Relatório de pesquisa. Brasília, 2006a.

INSTITUTO OLHAR ETNOGRÁFICO. Relatório etnográfico parcial ( $2^{\circ}$ produto): fevereiro a abril de 2006. Projeto valorização e adequação dos sistemas de partos tradicionais das etnias indígenas do Acre e do Sul do Amazonas. Relatório de pesquisa. Brasília, 2006b.

KEIFENHEIM, B. Nawa: un concept clé de l'altérité chez les Pano. Journal de la Société des Américanistes, 76: 79-94, 1990.

KENSINGER, K. How Real People Ought to Live: the Cashinahua of Eastern Peru. Illinois: Waveland Press, 1995.

LABATE, B. C. A literatura brasileira sobre as religiões ayahuasqueiras. In: LABATE, B. C. G ARAÚJO, W. S. (Orgs.). O Uso Ritual da Ayahuasca. São Paulo: Mercado de Letras, 2002.

LAGROU, E. Caminhos, Duplos e Corpos: uma abordagem perspectivista da identidade e a alteridade entre os Kaxinawa, 1998. Tese de Doutorado, São Paulo: Universidade de São Paulo, 1998.

LAGROU, E. A Fluidez da Forma: arte, alteridade e agência em uma sociedade amazônica (Kaxinawá, Acre). Rio de Janeiro: Topbooks, 2007. 
LANGDON, J. Xamanismo no Brasil: novas perspectivas. Florianópolis: UFSC, 1996.

LANGDON, J. Uma avaliação crítica da atenção diferenciada e a colaboração entre antropologia e profissionais de saúde. In: LANGDON, E. J. G GARNELO, L. (Orgs.). Saúde dos Povos Indígenas: reflexões sobre antropologia participativa. Rio de Janeiro: Contra Capa Livraria, ABA, 2004.

LANGDON, J. Diversidade cultural e os desafios da política brasileira de saúde do índio. Saúde e Sociedade, 16(2): 7-12, 2007.

MACEDO, G. Notas sobre o Projeto Vigisus II e o subsistema de saúde indígena. In: FERREIRA, L. O. G OSÓRIO, P. (Orgs.). Medicina Tradicional Indígena em Contextos. Reunião de Monitoramento, 1, 2007, Brasília. Anais... Brasília: Projeto Vigisus II, Funasa, 2007.

MANHEIM, B. G TEDLOCK, D. Introducion. In: MANHEIM, B. G TEDLOCK, D. (Eds.). The Dialogic Emergence of Culture. Urbana: University of Illinois Press, 1995.

MAUSS, M. Ensaio sobre a Dádiva. Portugal: Edições 70, 1950.

McCALluM, C. Gender, Personhood and Social Organization among the Cashinahua of Western Amazonia, 1989. Thesis (PhD), London: London School of Economics, University of London.

McCALLUM, C. Aquisição de gênero e habilidades produtivas: o caso kaxinawá. Dossiê Mulheres Indígenas. Revista Estudos Feministas, 7(2): 157-175, 1999.

McCALLUM, C. Incas e Nawas: produção, transformação e transcendência na história Kaxinawa. In: ALBERT, B. G RAMOS, A. R. (Orgs.). Pacificando o Branco: cosmologias do contato no Norte-Amazônico. São Paulo: Editora Unesp, Imprensa Oficial do Estado, 2002.

MENÉNDEZ, E. Modelos de atenção dos padecimentos: de exclusões teóricas e articulações práticas. Ciência G Saúde Coletiva, 8(22): 185-207, 2003.

MONTERO, P. Índios e missionários no Brasil: para uma teoria da mediação cultural. In: MONTERO, P. (Org.). Deus na Aldeia: missionários, índios e mediação cultural. São Paulo: Globo, 2006.

ORGANIZAÇÃ̃o DAS NAÇÕES UNIDAS (ONU). Declaração das Nações Unidas sobre os Direitos dos Povos Indígenas. Rio de Janeiro: ONU, 2007.

ORGANIZAÇÃO INTERNACIONAL DO TRABALHO (OIT). Convenção n. 169 sobre povos indígenas e tribais em países independentes da Organização Internacional do Trabalho. Genebra: OIT, 1989.

ORGANIZAÇÃO MUNDIAL DA SAÚDE (OMS). Tecnologia apropriada para nascimento e parto. The Lancet, 24: 436-437, 1985.

ORGANIZAÇÃO MUNDIAL DA SAÚDE (OMS). Estratégias de la OMS sobre Medicina Tradicional 2002-2005. Genebra: OMS, 2002.

ORTNER, S. B. Poder e projetos: reflexões sobre a agência. In: GROSSI, M. P.; ECKERT, C. G FRY, P. H. (Orgs.). Conferências e Diálogos: saberes e práticas antropológicas. Blumenau: Nova Letra, 2007.

PEREZ GIL, L. Possibilidades de articulação entre os sistemas de parto tradicionais indígenas e o sistema oficial de saúde no Alto Juruá. In: FERREIRA, L. O. G OSÓRIO, P. (Orgs.). Medicina Tradicional Indígena em Contextos. Reunião de Monitoramento, 1, 2007, Brasília. Anais... Brasília: Projeto Vigisus II, Funasa, 2007. 
RICOEUR, P. El lenguaje como discurso. In: RICOEUR, P. (Ed.). Teoría de la Interpretación: discurso y excedente de sentido. Madrid: Siglo Veintiuno Editores, 1995.

RICOEUR, P. Percurso do Reconhecimento. São Paulo: Edições Loyola, 2006.

SAHLINS, M. O pessimismo sentimental e a experiência etnográfica: por que a cultura não é um objeto em via de extinção (parte 1). Mana, 3(1): 41-73, 1997 a.

SAHLINS, M. O pessimismo sentimental e a experiência etnográfica: por que a cultura não é um objeto em via de extinção (parte 2). Mana, 3(2): 103-150, 1997b.

SANTOS-GRANERO, F. G BARCLAY, F. Introducción. In: SANTOS GRANERO, F. G BARCLAY, F. (Eds.). Guía Etnográfica de la Alta Amazonia. Quito: Smithsonian Tropical Research Institute, Abya-Yala, 1998.

SEEGER, A. Corporação e corporalidade: ideologias de concepção e descendência. In: SEEGER, A. Os Índios e Nós: estudo sobre sociedades tribais brasileiras. Rio de Janeiro: Campus, 1980.

SEEGER, A.; DA MATTA, R. G VIVEIROS DE CASTRO, E. A construção da pessoa nas sociedades indígenas brasileiras. In: OLIVEIRA FILHO, J. P. (Org.). Sociedades Indígenas e Indigenismo no Brasil. Rio de Janeiro: Marco Zero, Editora UFRJ, 1987.

STRATHERN, M. O Gênero da Dádiva: problemas com as mulheres e problemas com a sociedade na Melanésia. Campinas: Editora da Unicamp, 2006.

TAYLOR, C. A política do reconhecimento. In: TAYLOR, C. Multiculturalismo: examinando a política de reconhecimento. Lisboa: Instituto Piaget, 1994.

THIOLlent, M. Metodologia de Pesquisa-Ação. São Paulo: Cortez, 2007.

TORNQUIST, C. S. Parto e Poder: o movimento pela humanização do parto no Brasil, 2004. Tese de Doutorado, Florianópolis: Universidade Federal de Santa Catarina.

VIVEIROS DE CASTRO, E. A fabricação do Corpo na Sociedade Xinguana. In: OLIVEIRA FILHO, J. P. (Org.). Sociedades Indígenas e Indigenismo no Brasil. Rio de Janeiro: Marco Zero, Editora UFRJ, 1987.

VIVEIROS DE CASTRO, E. Os pronomes cosmológicos e o perspectivismo ameríndio. Mana, 2(2): 115-144, 1996.

WAGNER, R. A Invenção da Cultura. São Paulo: Cosac Naify, 2010. 
Formato: $21 \times 26 \mathrm{~cm}$

Tipologia: Egyptian505 BT

Papel: Off set $90 \mathrm{~g} / \mathrm{m}^{2}$ (miolo)

Cartão supremo $250 \mathrm{~g} / \mathrm{m}^{2}$ (capa)

CTP, impressão e acabamento: Imo's Gráfica e Editora Ltda.

Rio de Janeiro, maio de 2013.

Não encontrando nossos títulos em livrarias, contactar a Editora Fiocruz:

Av Brasil, 4036 - térreo - Manguinhos

21040-361 - Rio de Janeiro - RJ

Telefones: (21) 3882-9039 e 3882-9041

Telefax: (21) 3882-9006

editora@fiocruz.br

www.fiocruz.br/editora 